\title{
IN THE AFTERMATH OF THE JATROPHA BOOM
}

Exploring socio-political and ecological dynamics in 'failed' jatropha spaces in Ghana







\section{IN THE AFTERMATH OF THE JATROPHA BOOM}

Exploring socio-political and ecological dynamics in 'failed' jatropha spaces in Ghana 
ISBN: 978-94-6416-605-7

ELECTRONIC ISBN: 978-94-6416-606-4

Printing: Ridderprint - www.ridderprint.nl

Cover design: Richmond Antwi-Bediako

Layout: Richmond Antwi-Bediako

Cover Picture: Richmond Antwi-Bediako

(C) 2021 Richmond Antwi-Bediako. All rights reserved. No part of this publication may be reproduced, stored in a retrieval system, or transmitted, in any form or by any means, electronic, mechanical, photocopying, recording, or otherwise, without prior permission in writing from the proprietor. 


\section{IN THE AFTERMATH OF THE JATROPHA BOOM \\ Exploring socio-political and ecological dynamics in 'failed' jatropha spaces in Ghana}

IN DE NASLEEP VAN DE JATROPHA BOOM:

Onderzoek naar sociaal-politieke en ecologische dynamiek in 'mislukte' jatropha-ruimtes in Ghana

(met een samenvatting in het Nederlands)

Proefschrift

ter verkrijging van de graad van doctor aan de Universiteit Utrecht op gezag van de rector magnificus, prof.dr. H.R.B.M. Kummeling, ingevolge het besluit van het college voor promoties in het openbaar te verdedigen op vrijdag 21 mei 2021 om 10.15 uur

door

Richmond Antwi-Bediako

geboren op 14 juni 1968

te Accra, Ghana 


\section{Promotor:}

Prof. dr. E.B. Zoomers

\section{Copromotoren:}

Dr. K. Otsuki

Dr. A. Amsalu

Dit proefschrift is mogelijk gemaakt met financiële steun van de Nederlandse Organisatie voor Wetenschappelijk Onderzoek 
This dissertation was written as part of the Conflict and Cooperation Over Natural Resources $(\mathrm{CoCooN})$ project and received financial support from the Netherland Organisation for Scientific Research (NWO). 



\section{CONTENTS}

ACKNOWLEDGEMENTS

DEDICATION

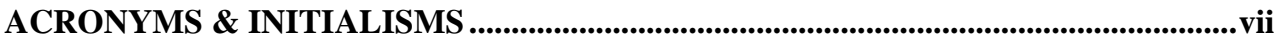

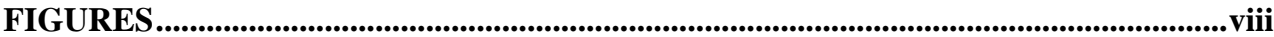

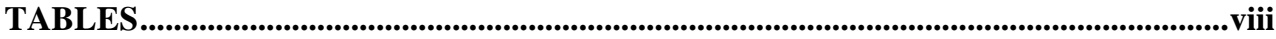

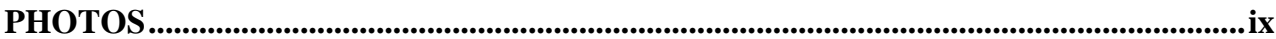

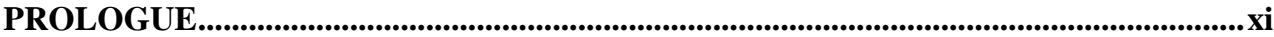

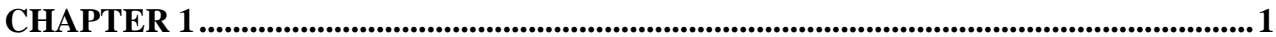

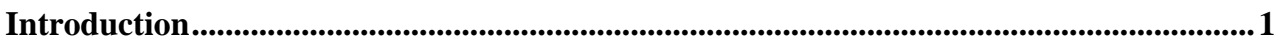

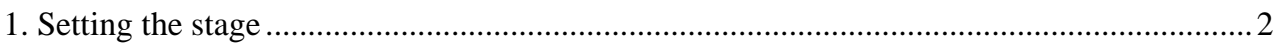

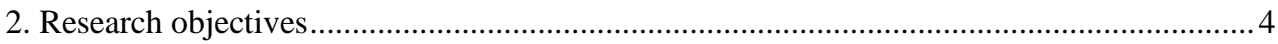

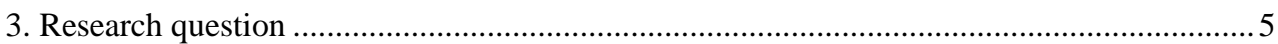

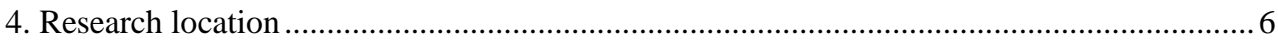

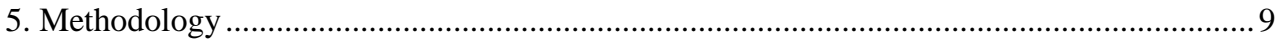

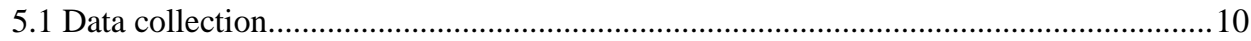

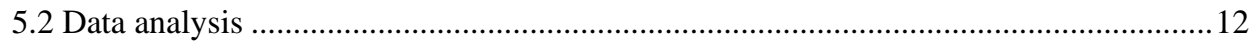

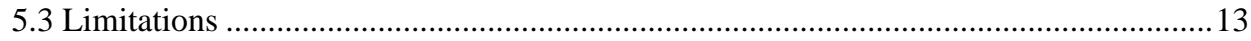

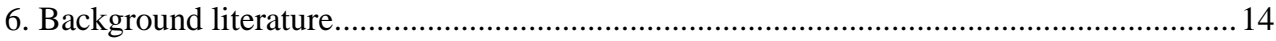

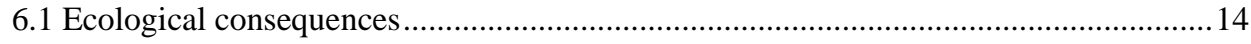

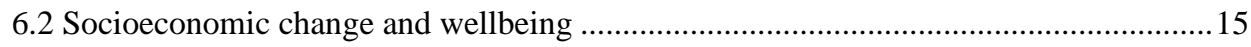

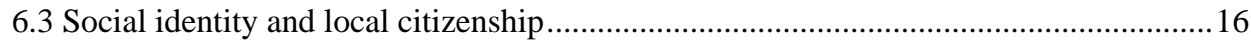

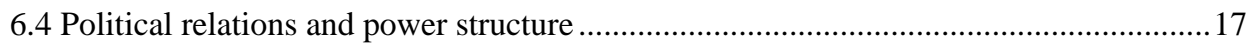

6.5 Jatropha space as an open-ended socioecological system........................................ 18

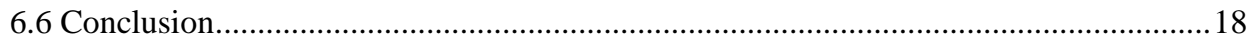

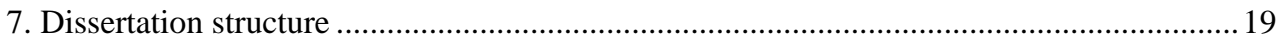

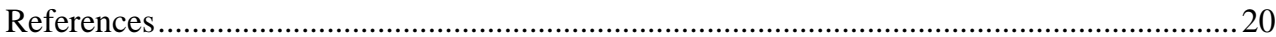


CHAPTER 2 .

Global investment failures and transformations:_A review of the boom and bust of

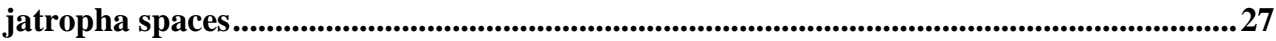

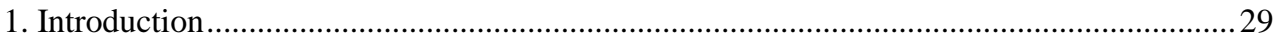

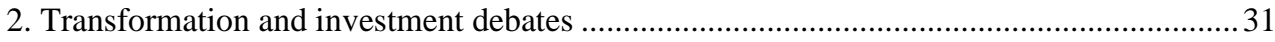

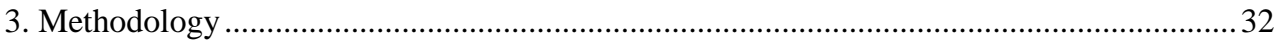

4. Review of country cases: Transformations during the jatropha regime ............................. 33

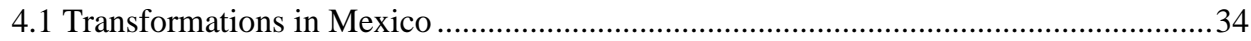

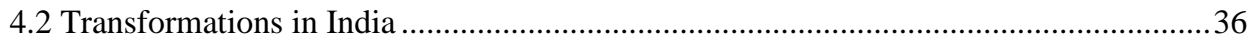

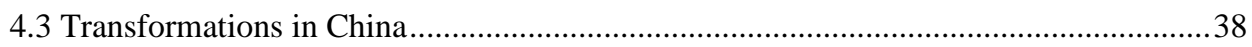

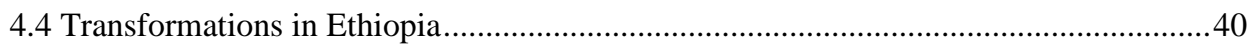

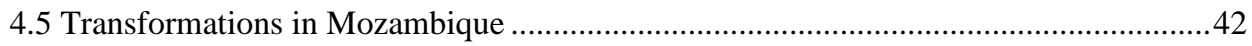

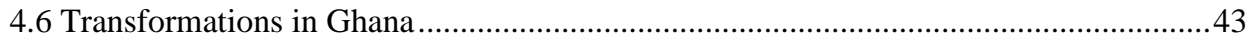

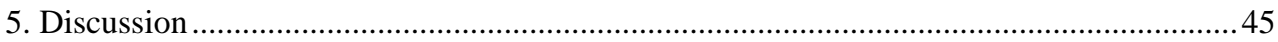

5.1 Transformations in government- versus corporate-led jatropha investment.................47

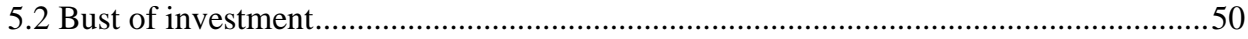

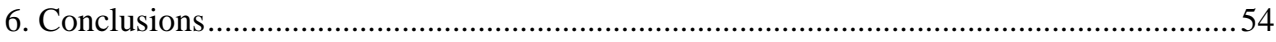

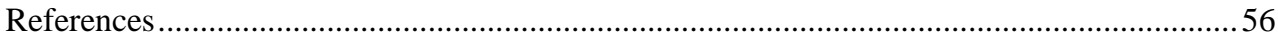

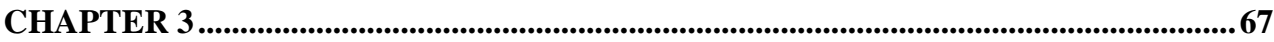

The case of Kobre:_From jatropha to abandonment .................................................................67

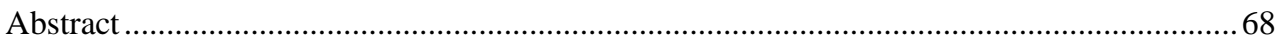

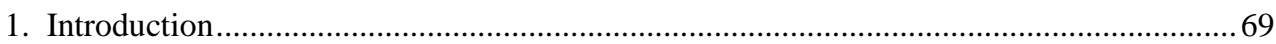

2. Migration, land tenure and investments in Pru East District ............................................ 70

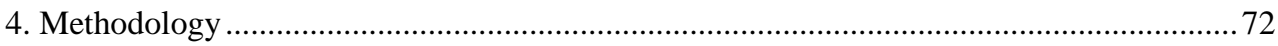

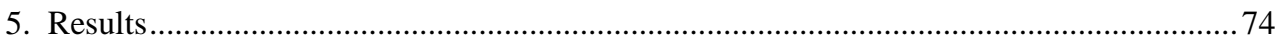

5.1 Historical trajectories of jatropha space in Pru East District. ...................................... 74

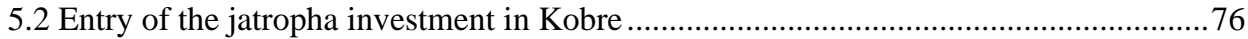

ii | P a g e 
5.4 Abandonment of the jatropha space and its impacts ................................................ 81

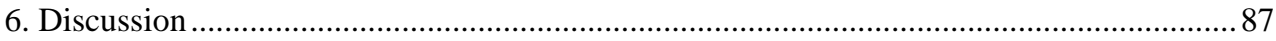

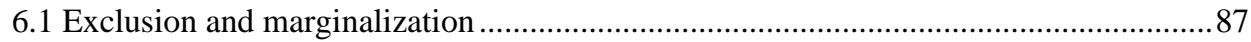

6.2 Opportunities and livelihood arrangements ......................................................... 89

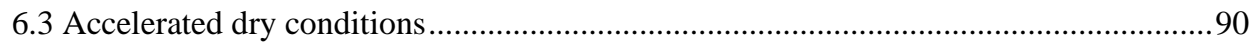

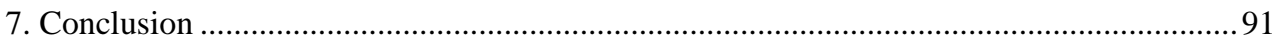

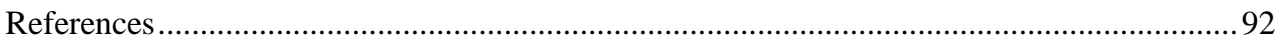

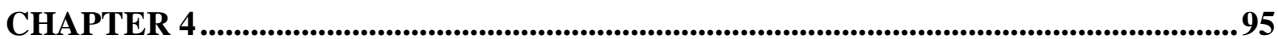

The case of Agogo: From jatropha to maize .........................................................................95

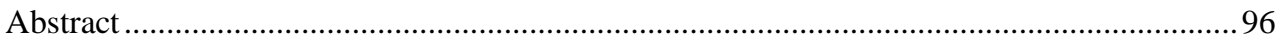

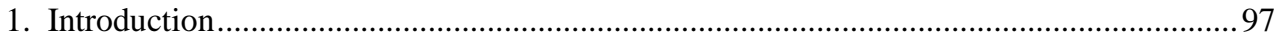

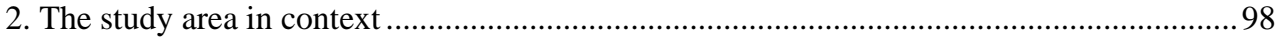

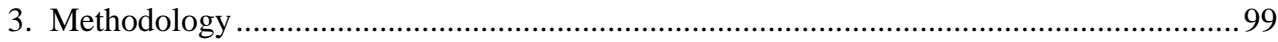

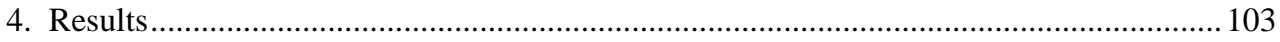

4.1 Before large-scale investment: The land tenure regime and conflicts ........................ 103

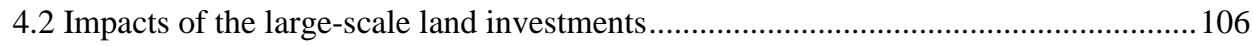

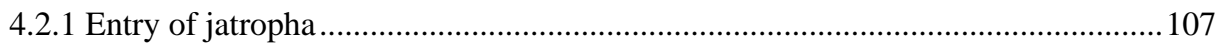

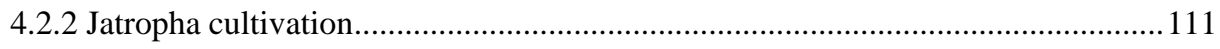

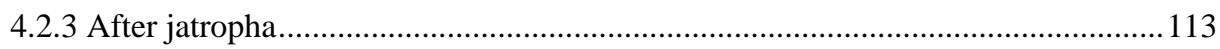

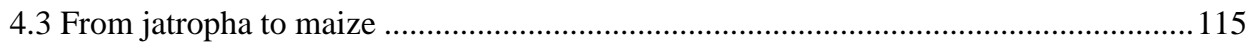

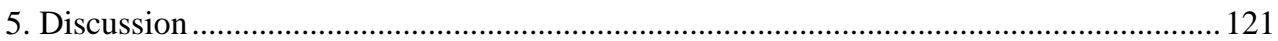

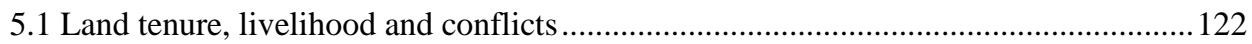

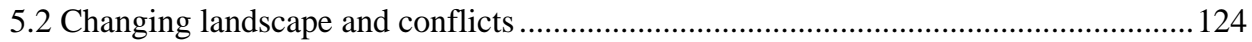

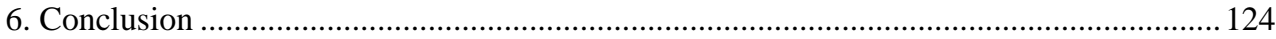

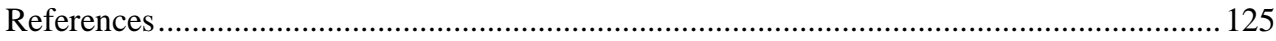


CHAPTER 5 .

The case of Lolito:_From jatropha to rice.............................................................................................128

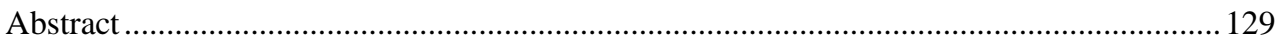

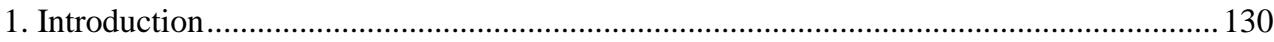

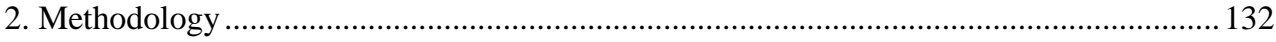

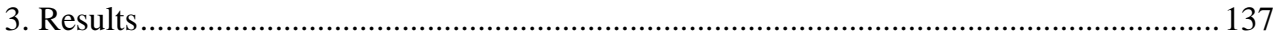

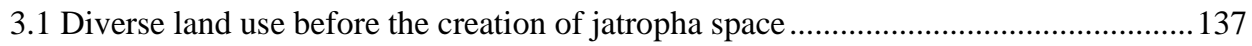

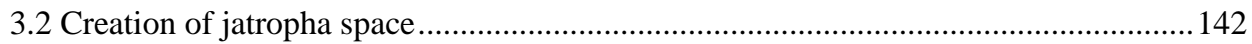

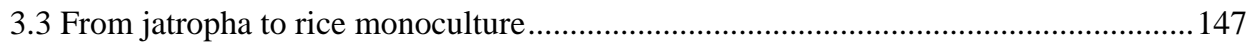

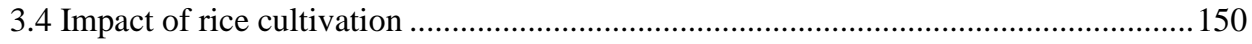

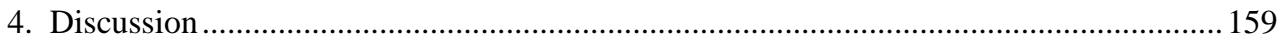

4.1 Socioeconomic and socio-political transformation of jatropha space......................... 160

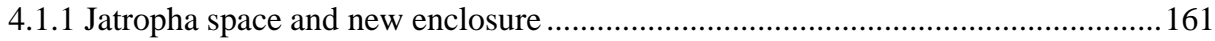

4.2 Alteration of ecology and implications for sustainable development .......................... 163

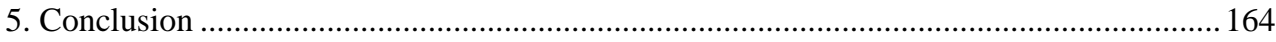

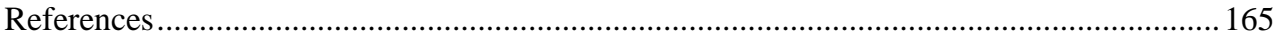

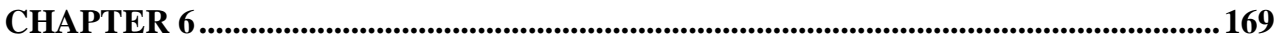

Synthesis: Towards inclusive and sustainable development after investment failures .169

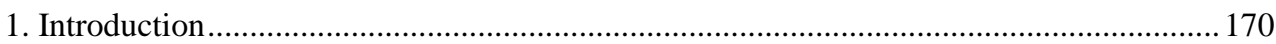

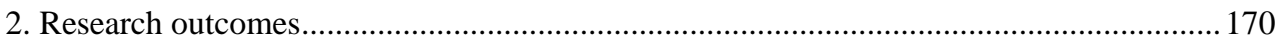

2.1 The unintended impacts of jatropha investments ................................................. 170

2.2 Impact implications observed in the three jatropha spaces ..................................... 171

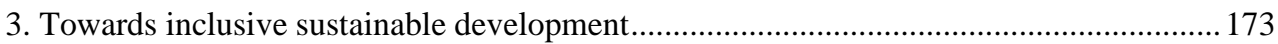

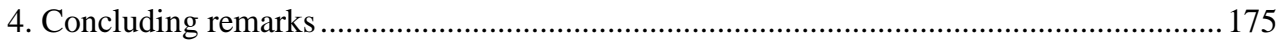

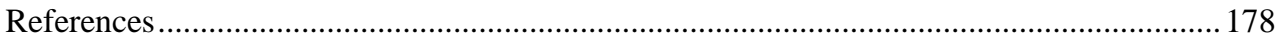

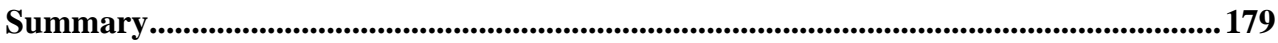

Samenvating ….................................................................................................................................. 182

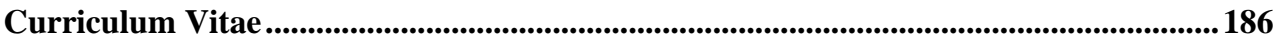




\section{ACKNOWLEDGEMENTS}

Having been inspired by a knowledge research and innovation programme titled Conflict and Cooperation Over Natural Resources (CoCooN) in developing countries, I carried out research on jatropha and rural land use in Ghana and Ethiopia, which would not have been possible without the financial support of the Netherlands Organization for Scientific Research (NWO), under grant number W07.68.305.00.

I should like to offer special thanks to my supervisor, Professor Annelies Zoomers, for her support throughout this $\mathrm{PhD}$ process, and for having trust in me and giving me the chance to continue my $\mathrm{PhD}$ under her supervision. Annelies, thank you for your invaluable and constructive inputs and comments. As you said in May 2019, 'The one who perseveres always wins'. I should like to thank my co-supervisors, Dr Kei Ostuki and Dr Aklilu Amsalu, for their insights and wonderful multifaceted support, advice and encouragement throughout the $\mathrm{PhD}$ process. You supported me greatly and I will never forget your collaboration, friendly approach, openness and kindness. Without your great support, this $\mathrm{PhD}$ project would have not been possible. I should also like to thank my colleagues and esteemed CoCooN-Jatropha partners, especially Dr Benjamin Betey Campion of Kwame Nkrumah University of Science and Technology, whose support, knowledge, valuable advice and encouragement were indispensable. My work would not have been possible without Abubakar Mohammed, my research assistant at the Rural Environmental Care Association (RECA), who provided me with ceaseless field assistance.

My gratitude goes to my wife, Faustina, for her invaluable advice, encouragement, sincerity, kindness, patience and love. To my children Tracy, Nostradamus, Richard and Richmond Jr: thank you for the times you made sacrifices and endured my absence from home. I should like to express my very great appreciation to my sister-in-law, Doris Amemo Ansah, and my friend Modesta Ramona Monegro. I am grateful for your support, love, kindness and encouragement. I thank Mr Emmanuel Tetteh, formerly of the Centre for Remote Sensing and Geographical Information Systems (CERGIS), for assisting me with my digital maps. I should also like to thank the experts and extension workers, farmers and local leaders involved in the focus group discussions and mini-workshops for their loyalty and great support.

My life would not be complete without my family and friends. You know who you are. My greatest indebtedness is to you all for standing by me all these years. I trust you will continue to do so in the years to come. 


\section{DEDICATION}

To God for His lasting love, grace, mercy and provisions

and

to my wife, Faustina

vi|P a g e 


\section{ACRONYMS \& INITIALISMS}

BABGL Brazil Agro-Business Group Limited

CoCooN Conflict and Cooperation over Natural Resources in Developing Countries

EBDD Ethiopian Biofuels Development Directorate

ECOWAS Economic Community of West African States

FAO Food and Agriculture Organisation

FDRE Federal Democratic Republic of Ethiopia

FGD Focus group discussion

GCAP Ghana Commercial Agriculture Project

GHGs Greenhouse gases

GNA Ghana News Agency

GSS Ghana Statistical Service

IICA Instituto Interamericano de Cooperación para la Agricultura

IIED International Institute for Environment and Development

ILC International Land Coalition

KITE Kumasi Institute of Technology, Energy and Environment

MoFA Ministry of Food and Agriculture

MoME Ministry of Mines and Energy

NGO Non-governmental organization

NWO Netherlands Organization for Scientific Research

RECA Rural Environmental Care Association

TC Traditional council

TCPD Town and Country Planning Department

UNDESA United Nations Department of Economic and Social Affairs

USAID United States Agency for International Development 


\section{FIGURES}

Figure 1.1 Outline of the research strategy for exploring socio-political and ecological dynamics in 'failed' jatropha spaces in Ghana

Figure 1.2 Location of the three selected the communities (Kobre, Agogo and Lolito) in Ghana

Figure 2.1 Jatropha investment sources and utilization

Figure 2.2 Global transformations trajectories of jatropha investments

Figure 3.1 Ghana's traditional power structure and hierarchy

Figure 3.2 Map of Pru East District, showing the project area near Kobre

Figure 4.1 Map of Asante Akim North district, showing the capital, Agogo, and ScanFarm investment area

Figure 4.2 Migration of Fulani herdsmen from Fulani settlements in the Sahel region to the Agogo Traditional Area

Figure 4.3 Trajectory in Agogo Traditional Area before and after large-scale investment

Figure 4.4 Area of land in the Agogo area initially acquired by ScanFuel in 2007

Figure 4.5 Area of land legitimately acquired by ScanFuel after ceding 6,000 ha to Bernard Kojo Ofori Teak Plantation Limited in 2008

Figure 4.6 Map of the Agogo area, showing land acquired by ScanFarm for jatropha and the cultivated and uncultivated areas

Figure 5.3 Map of South Tongu District, showing investment area

Figure 5.4 Map of South Tongu District of Ghana showing the Brazil Agro-Business Group Limited project area in 2018

Figure 5.5 Map of South Tongu showing community perceived land use maps before jatropha investment

Figure 5.6 Land use and land cover in the investment area during the jatropha era

Figure 5.7 The current rice cultivation area of Brazil Agro-Business Group Limited in South Tongu District

\section{TABLES}

Table 1.1 Some well-known jatropha investments in Ghana

Table 1.2 Key informants and participants in focus group discussions (FGDs) in the three study communities 
Table 2.1 Global perspective on transformation creation in different jatropha centres

Table 3.1 Summary of project area in Kobre

Table 3.2 Key informants and participants in focus group discussions (FGDs) in Kobre

Table 3.3 Summary of impacts of jatropha investments until its abandonment in Kobre

Table 4.1 Summary of the project in the Agogo area

Table 4.2 Key informants and participants in focus group discussions (FGDs) in the Agogo area

Table 4.3 Summary of conflicts before, during and after jatropha investment in the Agogo area

Table 5.2 Summary of project area in Lolito

Table 5.2 Key informants and participants in focus group discussion in Lolito

Table 5.3 Impacts before introduction of jatropha in Lolito area

Table 5.4 Impacts of rice production in the Lolito area of South Tongu District

Table 5.5 Summary of impacts of transformations in jatropha space in Lolito

\section{PHOTOS}

Photo 3.1 Migrants' housing units at Kobre

Photo 3.2 Kimminic's Jatropha farm during RECA biofuel scoping in Ghana, 2009

Photo 3.3 Some of the abandoned infrastructure after the abandonment of the investment

Photo 3.4 Landscape after abandonment

Photo 4.5 Abandoned jatropha farms on ScanFarm concession

Photo 4.6 A ScanFarm 'Acquired Lands' sign on the Agogo-Etwira Highway

Photo 4.7 ScanFarm maize plantation in the Agogo area

Photo 5.8 Mat weaving - one of the community’s livelihood activities

Photo 5.9 Sugarcane cultivation in marshy area to supply the processing plant for alcohol distillation in the South Tongu area

Photo 5.10 Biofuel Africa Limited jatropha demonstration farm in Lolito

Photo 5.11 A Wosornu Foundation sign in Lolito

Photo 5.12 Site for the BABGL out-grower scheme for rice cultivation for 30 community members

Photo 5.13 Irrigation infrastructure sourcing water from the Volta River to irrigate the rice farm

Photo 5.14 Interviews in Lolito with key informants, the manager of Brazil Agro-Business Group Limited and the MoFA district agriculture officer. 
Photo 5.15 Site prepared (first photo) and cultivated (second photo) for rice cultivation

Photo 5.16 Farm adjoining investment threatened by the expansion of rice

Photo 5.17 Neem trees fetched for firewood and for sale before rice investment

Photo 5.18 River blocked by a road built by the investor to link its factory to its field site 


\section{PROLOGUE}

As a science student at Adisadel College in Ghana, I always thought I would best fit in a profession related to natural sciences. I therefore pursued a diploma in Laboratory Technology and then a BSc in Chemistry and Biology, both at the University of Cape Coast, Ghana. After that, I worked for the University of Ghana Medical School, the Radio-pharmacy unit of Ghana Atomic Energy Commission, Teberabie Goldfields and later Transworld Laboratories Limited - a geochemical mining laboratory in Tarkwa, Ghana. Tarkwa is a mining enclave of several small- and large-scale mining companies as well as illegal mining actors popularly known as galamseyers. During my engagement with the mining laboratory company, I constantly needed to visit and study communities affected by mining activities, as well as the surrounding natural environment, and write technical reports. My exposure to the environmental challenges faced by these communities and the negative livelihood and food security experiences changed my initial conviction and career efforts.

I then developed an unswerving interest in changing the narrative, starting with the affected communities. With my new determination to effect change, my goal was to influence decision making on the environmental and socioeconomic impacts on community resources. I started asking myself: 'How can I achieve this goal?' My regular contact with the deprived communities was a constant reminder that I had to do something to help save them from environmental degradation and its negative implications. Through the regular sharing of my perspectives with others, I became convinced of the need to change my career path to environmental management and social development. Therefore, whilst I was working in the mining enclave in Tarkwa, I started an environmental club that focused on environmental advocacy in an attempt to reverse the detrimental nature of the environment in communities surrounding the mining company. The support from the local communities was tremendous, and this set the pace for my advocacy efforts. I realized that the communities could take a responsive role in managing their own environment in a sustainable way if given support. I registered the club as an NGO - the Rural Environmental Care Association (RECA) - with a key focus on activities that will ensure the security of land tenure, community-based land administration, natural resource management, biodiversity management, and a reduction in child labour and trafficking. I resigned from the mining company and engaged extensively in the activities of RECA.

By 2010, jatropha had been hyped as a miracle crop that alleviates energy poverty, reduces harmful emissions from fossil fuels, advances environmental management and 
improves the livelihoods of local communities. Investors had moved into Ghana, Ethiopia and many other African countries to engage in large-scale jatropha cultivation and processing. Against this backdrop, in 2010 my NGO and I participated in the Conflict and Cooperation over Natural Resources in Developing Countries (CoCooN) knowledge research and innovation programme of the Netherlands Organization for Scientific Research (NWO) to undertake in-depth research on jatropha investments in Ghana and Ethiopia. RECA, along with five other consortium members, carried out research into the socioeconomic outcomes of jatropha in relation to the alienation of community members from their lands and the emergence of conflicts. The five other consortium members were Bothends of Netherlands; Africa Forest Research Initiative on Conservation and Development (AFRICAD) of British Columbia University; Kwame Nkrumah University of Science and Technology (KNUST); Addis Ababa University; and Horn of Africa Regional Environmental Centre and Network (HOAREC). Utrecht University (the Netherlands) joined the programme after the second year.

Specific issues covered by the research included rural land use and its implications in the era of jatropha, livelihood implications, environmental outcomes, food security, and conflict and cooperation in Ghana and Ethiopia. In the context of Ghana, the study covered 10 companies that had invested in large-scale jatropha projects in the three ecological zones of Ghana, namely Guinea savannah woodland, semi-deciduous forest (or the transition zone), and coastal shrub and savannah zones. Jatropha investment outcomes were generally negative. First and foremost, jatropha investments led to the loss of land by community members to jatropha investors, and these people received little or no compensation. This resulted in conflicts between investors, the local people and traditional leaders, and among community members, especially farmers. Second, food production was affected due to the takeover of lands, of which less than $10 \%$ was put under jatropha cultivation. Third, the alteration of the natural environment caused a loss of biodiversity and non-timber forest products (NTFPs). The jatropha business generated employment to a limited extent, but income levels were very low, especially for affected community members in general.

The research further identified that the jatropha hype was rapidly coming to an end. The collapse of jatropha was attributed to the absence of a local market for the new crop, a lack of policy guidelines and frameworks to support jatropha cultivation, and limited funding. The yields of jatropha were far lower than expected based on background studies on the crop, while unscrupulous land deals in the host communities and issues of food insecurity remained unresolved. During this research on jatropha and its failure, my interest in doing a $\mathrm{PhD}$ was 
heightened. I was determined to research emerging issues that have a wide scope of benefits for communities globally, and the evolving issues on the jatropha hype and collapse naturally became of interest. Being part of the $\mathrm{CoCooN}$ project, I was familiar with members of the project communities, and going back to those communities to research the transformations following the collapse of jatropha investments and/or the creation of new investments by introducing new crops was something I wanted to do. Data collected during the era of the jatropha hype were available for me to tap into, and wide range of experts interlinked with the CoCooN project were available for me to engage with for my $\mathrm{PhD}$ studies.

Beginning in November 2014, I made regular field visits to three jatropha communities in Ghana to understand the transformation and changes during jatropha investment and after the bust of that investment. Meanwhile, reading scholarly papers on jatropha in an attempt to find something striking about jatropha transformations, I realized that after the bust of jatropha in Ghana and elsewhere, there was a lack of interest in researching the aftermath of jatropha investments, in particular what investments and their failures have created in jatropha spaces in Ghana. I thus concentrated my efforts on reigniting research interest in the spaces created and transformed by jatropha investments and failures. This dissertation discusses the various transformations and reveals the previously unknown outcomes and complexities before and during the jatropha hype, and after the bust of jatropha. 



\title{
CHAPTER 1
}

\author{
Introduction
}




\section{Setting the stage}

Jatropha investment was strongly promoted as part of the land investment boom of the 2000s because of the growing global demand for climate-friendly fuels, energy security and rural development in the global South (Antwi et al., 2010; Jingura et al., 2011; Tsegaye \& Glantz, 2011; Favretto et al., 2012; Yusuf, 2012; Timko et al., 2014; Gasparatos et al., 2015). Jatropha investment, then a preferred option, was hyped in the policy space and trumpeted as a development success with such heartening names as 'miracle crop', 'wonder crop', 'biofuel diesel crop', 'poverty-combatting crop', 'marginal-land friendly crop' - in other words, the crop that supports inclusive sustainable development (Deininger \& Byerlee, 2011; Schoneveld et al., 2011; Edelman et al., 2013; Portner et al., 2013; Schoneveld et al., 2013; Boamah, 2014; Von Maltitz et al., 2014; Schoneveld, 2014 ). Governments became the major driving force behind jatropha investment, supporting large corporations by formulating policies and enacting laws to stimulate large-scale cultivation through foreign direct investment (FDI) (Ohimain, 2007; Ahmed et al., 2017). The assumption that jatropha investment can transform the physical, economic and social conditions of local communities through a technological influx and higher gains from job creation and advance economic growth while meeting global energy needs, made jatropha a preferred option for governments in the global South. Borras et al. (2010) and Anseeuw et al. $(2012,2013)$ pointed out that this assumption is often contrary to local realities, and as such, societal inequalities and complexities within the socio-political and ecological space progressively deprive people of their basic agrarian livelihoods, especially through land dispossession and the subsequent loss of livelihood.

These societal inequalities and complexities led to questions regarding whether jatropha investment was the way forward for inclusive sustainable development (Morris, BinswangerMkhize \& Byerlee, 2009). By the mid-2010s it was obvious that despite government incentives, jatropha investment was in contention with local realities. The accompanying local complexities further exacerbated the waning interest in jatropha and hindered the anticipated contributions to a greener economy or the ability to serve as a commercially viable alternative fuel (Von Maltitz et al., 2014; Portner et al., 2013). The prospects of the jatropha business became dire, contrary to the initial hype, and was unprofitable to pursue (Bos et al., 2008). Instead of jatropha being a safe investment, it became a huge risk venture for investors, leading to mass withdrawals from jatropha and cultivated spaces, mostly in 2010. Large-scale jatropha cultivation was eventually recognized as the first major failure of investments in the 2010s in many countries throughout the world. 
Observations of the failed jatropha investment space have generally juxtaposed the failure within the context of ethical issues resulting from inexplicable complexities and contentious socio-political and socioeconomic implications (Kant \& Wu, 2011; Ahmed et al., 2019). Few scholarly studies have emphasized observations on the aftermath of jatropha investment failure. Most studies have focused on the measurable impact of the investments and corporate social responsibility, with limited knowledge of the trajectories of the investments and their impacts on local people, and not on the aftermath of investment failure and the impacts on the people and environment. It seems that scholarly debates on investments stop when investment failure begins. Thus, global evidence on the socio-political and ecological dynamics in 'failed' jatropha investment spaces is absent from the scholarly debate.

By the early 2010s, Ghana - like several other countries - had experienced the rapid rise and fall of jatropha investments (Schoneveld, 2014; Ahmed et al., 2017; Ahmed et al., 2019) along with various forms of socioecological transformations. While the jatropha investment space in Ghana has been part of the global scholarly debate, the wide knowledge gap surrounding new insights into and lessons on rural spaces over time during and after the jatropha investment failure remains. This raises key questions and makes Ghana an interesting case study to provide new insights. Ghana's case is particularly interesting because of its reputation as a major epicentre of former jatropha investment spaces with visible investment trajectories of jatropha up to the collapse of the whole scheme. The conversion of former jatropha spaces into large-scale agricultural spaces owing to government policies and decisions invariably attracts FDI. In addition, complex customary land systems and a strong traditional influence over the land tenure systems make the situation worth exploring.

In particular, the influence of traditional authorities regarding land tenure is not formally regulated and thus has not been clearly observed by outsiders, especially investors. The lack of a clear understanding of this influence led to deeper conflicts as the jatropha and subsequent crop failure and crop change started to affect tenure relationships. The conflicts also revealed that the rural communities consist not of a homogenous group of smallholders but of different groups of people, including indigenous smallholders, pastoralists and migrant land users.

This complex local context is difficult to grasp, and when there is investment failure, little is learned from its aftermath, or about what the aftermath of investment failure has done to local institutions, the ecology or the people's social relationships. Consequently, the implications of the aftermath of investments for these jatropha spaces with respect to inclusive sustainable development are absent from the socioecological development narratives. Against this backdrop, the aim of the present research was to deepen our understanding of the large- 
scale land investment trajectories, and especially the aftermath of investment failures and their impact dynamics, by following the transformation of three former epicentres of jatropha investment in Ghana.

\section{Research objectives}

The research underlying this dissertation explored how the dynamics of investment trajectories have transformed jatropha spaces, and what investments and their failures have created in these spaces in Ghana. The aim was to empirically establish the transformations that occurred from the inception of the jatropha investment to the aftermath of jatropha failure by conceptualizing a jatropha space as a complex socioecological system disrupted by a longitudinal process of change. Theoretically, the research challenged the assumption that transformation associated with investment is a structural and linear process, because of the unforeseen complexities affecting relationships in a socioecological system. As investment failure is a new transformation and new complexities emerge, this might lead to new opportunities or insecurities in a socioecological system. In other words, the study paid attention to the continuity of change and regarded a jatropha space as an open system exposed to uncertainties, unexpectedness and the unpredictable exclusion of different groups of affected people. More specifically, three sets of research objectives were established to explore how the dynamics of investment trajectories and their failures have transformed jatropha spaces. These objectives were:

(1) To review cases of jatropha investment in different countries and how the jatropha boom and bust contributed to global transformations

The review led to an overview of cases of jatropha boom and bust in six former major jatropha investment destinations, namely Mexico, India, China, Ethiopia, Mozambique and Ghana. The cases can be classified into government-driven and private sector-driven initiatives. The research explored specific socioeconomic and environmental impacts of these initiatives, and the failure of jatropha as an investment.

\section{(2) To explore the characteristics of jatropha production and its aftermath in Ghana, and} how it has impacted different types of geographical space

The encounters between the large-scale jatropha production and local indigenous and migrant peoples have had a significant impact on the latter's development agenda and their relationships even after the investment failure. The research sought to identify the impacts resulting from the 
creation of jatropha space before and after jatropha investment failure, and to analyse the impacts resulting from the abandonment of the space by the investors, and the change of investment from jatropha to a new crop.

\section{(3) To explore the implications for inclusive sustainable development and the lessons learned for land governance}

In this research, different cases of transforming jatropha spaces were synthesized to contribute to knowledge of the trade-offs between economic development, environmental sustainability and the social wellbeing of a large number of poor and vulnerable people.

\section{Research question}

To achieve the above objectives, the key research question was formulated as follows: What are the socio-political and ecological consequences of the jatropha boom and bust, and what kind of transformations have taken place since the failure of jatropha?

The sub-questions were:

i. How did the jatropha boom and bust contribute to global transformations and experiences in different countries?

ii. What were the characteristics of jatropha production and its aftermath in Ghana, and how has it impacted different types of geographical spaces?

iii. What are the implications for inclusive sustainable development and what are the lessons learned for land governance?

Conceptually, the research was orientated towards three areas of transformation, namely evolution over time, impact in different geographical realities, and responses. Evolution over time refers to the historical trajectories and experiences, from the hype of jatropha investment to the investment failure; impact in different geographical realities is about spatial differentiation of success and failure indicating the micro realities created by the investment trends, the failure of investment and the aftermath of investment failure; and responses are the recommended strategies of governance in the jatropha spaces. 


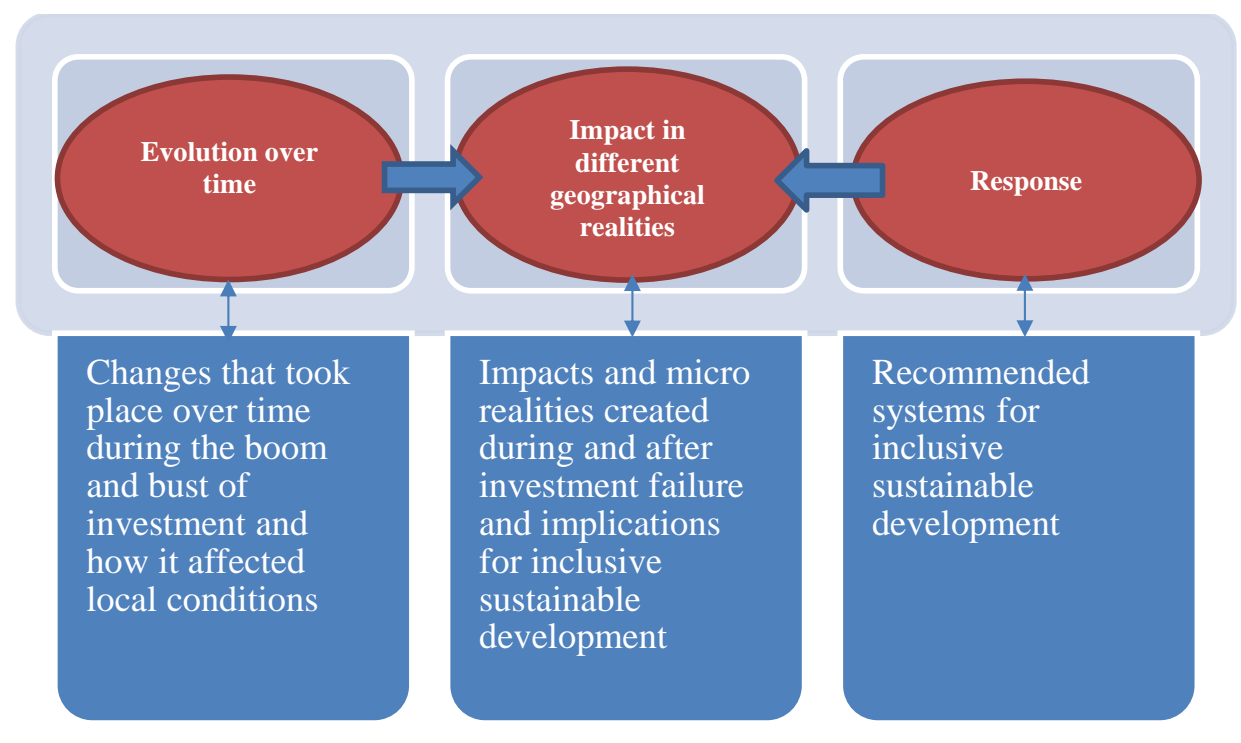

Figure 1.1: Outline of the research strategy for exploring socio-political and ecological dynamics in 'failed' jatropha spaces in Ghana

\section{Research location}

The research was conducted in Ghana in three former jatropha investment epicentres, namely Kobre (Brong East Region), Agogo (Ashanti Region) and Lolito (Volta Region) (see Figure 1.2). These three jatropha spaces were selected from 12 former jatropha investment epicentres studied in the CoCooN project referenced in the prologue (see Table 1.1). 
Table 1.1: Some well-known jatropha investments in Ghana

\begin{tabular}{|c|c|c|c|c|}
\hline No & Location & Name of investor & $\begin{array}{l}\text { Year of } \\
\text { investment }\end{array}$ & $\begin{array}{l}\text { Year of } \\
\text { investment } \\
\text { failure/ } \\
\text { abandonment }\end{array}$ \\
\hline 1 & Agogo, Ashanti Region & ScanFuel (now ScanFarm) & 2007 & 2011 \\
\hline 2 & $\begin{array}{l}\text { Ahenakrom, Brong Ahafo } \\
\text { Region }\end{array}$ & $\begin{array}{l}\text { Savannah Black Farming } \\
\text { and Farm Management } \\
\text { Limited }\end{array}$ & 2006 & 2011 \\
\hline 3 & $\begin{array}{l}\text { Kintampo, Brong Ahafo } \\
\text { Region }\end{array}$ & Jatropha Africa & 2007 & 2010 \\
\hline 4 & Kpachaa, Northern Region & Biofuel Africa & 2007 & 2011 \\
\hline 5 & Tamale, Northern Region & $\begin{array}{l}\text { Integrated Tamale Fruit } \\
\text { Company }\end{array}$ & 2007 & 2010 \\
\hline 6 & Winneba, Central Region & Anuanom Industries & 2006 & 2009 \\
\hline 7 & Yeji, Brong East Region & Smart Oil & 2008 & 2010 \\
\hline 8 & Bredie, Brong East Region & Kimminic Estate Limited & 2008 & 2012 \\
\hline 9 & Kobre, Brong East Region & Kimminic Estate Limited & 2008 & 2012 \\
\hline 10 & $\begin{array}{l}\text { Old Akrade-Juapong, Eastern } \\
\text { Region }\end{array}$ & Anuanom Farms & 2006 & 2011 \\
\hline 11 & Adidome, Volta Region & Galten Agro Limited & 2008 & 2011 \\
\hline 12 & Lolito, Volta Region & Biofuel Africa & 2007 & 2011 \\
\hline
\end{tabular}

Source: Author's own construct (2018)

Agogo, Kobre and Lolito were selected because they represent the three ecological zones of Ghana, namely Guinea savannah woodland, semi-deciduous forest (or the transition zone), and coastal shrub and savannah zones. The sites had different investors operating in them and different social dynamics and population groups. They serve as examples of failed investments with different patterns of investment trajectories and different impact dynamics of the aftermath of investment failure. 


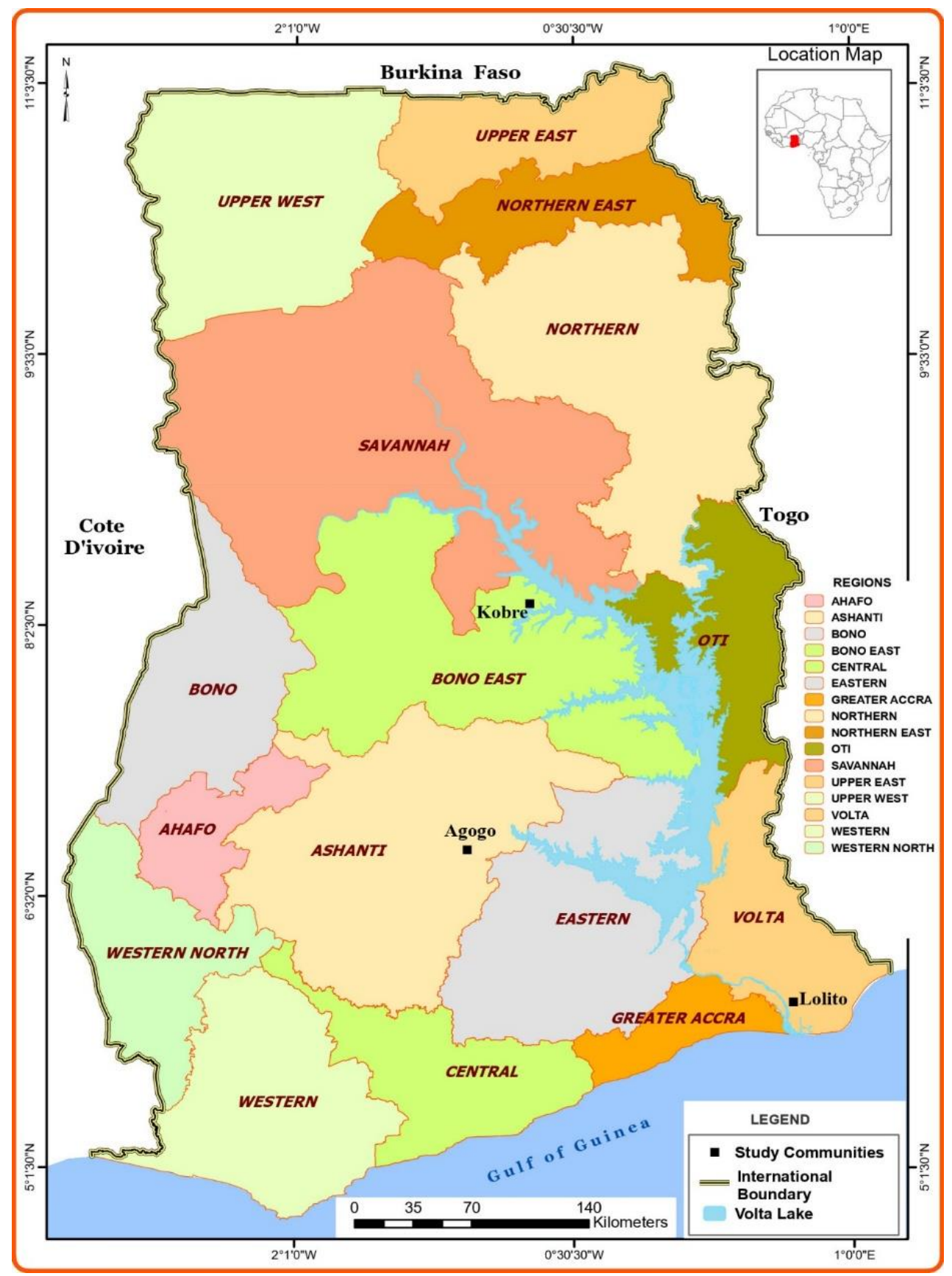

Figure 1.2: Location of the three selected the communities (Kobre, Agogo and Lolito) in Ghana 


\section{Kobre}

Kobre is in Pru East District within the Guinea savannah. It has a mixed population of indigenous and migrant farmers. About $23 \%$ of the population are migrant farmers, who mostly live in villages, such as Kobre, where the majority of the population (about 90\%) are migrant farmers. Kimminic Estates Limited - a jatropha investor in Kobre - is a well-known figure in the jatropha investment debate (Schoneveld et al., 2011; KITE, 2012). The effect of Kimminic's investments on migrant farmers and the neglect of such within the development discourse on investment trajectories and the implications of the jatropha investment failure and abandonment in Kobre, were the reasons for selecting Kobre as a case.

\section{Agogo}

The Agogo Traditional Area is in Asante Akim North District in the eastern part of the Ashanti Region of Ghana. The area is within the semi-deciduous forest ecological zone. The suitability of the area for crop farming and pastoralism has triggered diverse in-migrations and large-scale investments. ScanFuel - a jatropha investor that later diversified into maize as ScanFarm - is another well-known figure in the large-scale investment discourse (Acheampong \& Campion, 2014). The effect of jatropha investment and investment diversification into maize on migrant and indigenous farmers was the reason for selecting Agogo as a case.

\section{Lolito}

Lolito is in the coastal savannah zone in South Tongu District, in the Volta Region. Its inhabitants are mainly common pool resource users, mainly indigenous and migrant crop farmers, pastoralists, fisher folk and non-timber forest product (NTFP) users. The low-level coastal savanna zone (75 m above sea level) and available water resource in Lolito area attracted monoculture investments in jatropha (Biofuel Africa Limited) and later rice (Brazil AgroBusiness Group Limited). The trajectory of monoculture investments from jatropha to rice cultivation and how such investments have taken over jatropha spaces and exposed the vulnerability of common pool resource users, were the reasons for selecting Lolito.

\section{Methodology}

This research was informed by four years of fieldwork aimed at producing 'thick descriptions' from an insider's point of view (Geertz, 1973). The case study method as a research strategy has been helpful in investigating complex social, cultural and political phenomena (Verschuren, 
2003; Yin, 2003, 2006, 2017, Kothari, 2004). In addition, the long-term intermittent encounters in the field from 2010 to 2014 on the CoCooN-NWO 'Jatropha and rural land use' research project in Ghana and Ethiopia, during which I collected both primary and secondary data, gave me sufficient data insights into the case study area (Campion et al., 2012; Antwi-Bediako et al., 2012; Acheampong \& Campion, 2013, 2014; Campion \& Acheampong, 2014; Timko et al., 2014; Timko, 2014; Antwi-Bediako \& Mohammed, 2017; Tufa, et al., 2018 ). From November 2014 to March 2018, I critically observed, collected and analysed the perspectives of the key informants and focus groups who had experienced the jatropha investment trajectories from beginning to end. I also made use of a content analysis technique, which mainly involves drawing valid inferences through the systematic evaluation of open-ended data collected through field studies that could look relatively unstructured (as espoused by Paek et al., 2012).

\subsection{Data collection}

Primary data were collected through in-depth interviews and focus group discussions (FGDs) with 225 respondents, with the aim of understanding the concerns and complexities in the study area. The sample comprised 57 key informants - who discussed general concerns and issues in the study area - and 168 FGD participants, who provided in-depth information on how they were affected by the investments and their aftermath. Each interview and FGD session lasted 30-60 minutes, and the data were mostly collected through note taking and audio recordings. The 225 respondents were selected through both purposive and snowballing sampling techniques. Of the 225 respondents, 45 were from Kobre, 72 from Agogo and 108 from Lolito.

Table 1.2: Key informants and participants in focus group discussions (FGDs) in the three study communities

\begin{tabular}{|c|c|c|c|c|}
\hline Kobre & Type of respondent & FGD participants & Key informants & Total \\
\hline & $\begin{array}{ll}\text { - } & \text { Kimminic employees } \\
\text { (company workers) } \\
\text { - } & \text { Farmers } \\
\text { - } & \text { Ministry of Food and } \\
& \text { Agriculture } \\
\text { - } & \text { Traditional land owners } \\
\text { - } & \text { District Assembly members } \\
\text { - } & \text { Broker } \\
\end{array}$ & $\begin{array}{c}14 \\
8\end{array}$ & $\begin{array}{l}1 \\
9 \\
2 \\
6 \\
4 \\
1\end{array}$ & \\
\hline Subtotal & & 22 & 23 & \\
\hline Total & & & & 45 \\
\hline
\end{tabular}




\begin{tabular}{lcccc}
\hline Agogo & Type of respondent & FGD participants & Key informants & Total \\
& & & \\
& $\bullet$ & ScanFarm (company & 31 & 3 \\
& workers/management) & 24 & 3 \\
& $\bullet \quad$ Farmers & & 1 \\
& $\bullet$ Ministry of Food and & & 5 \\
& & Agriculture & 4 & \\
& $\bullet \quad$ Traditional land owners & & 17 & \\
& $\bullet \quad$ District Assembly & 55 & & $\mathbf{7 2}$ \\
\hline Subtotal & Broker & & & \\
\hline Total & & &
\end{tabular}

\begin{tabular}{|c|c|c|c|c|}
\hline Lolito & Type of respondent & FGD participants & Key informants & Total \\
\hline Subtotal & $\begin{array}{ll}\text { - } & \text { Biofuel Africa / Brazil } \\
\text { Agri-business Group } \\
\text { (company workers/ } \\
\text { management) } \\
\text { - } & \text { Farmers } \\
\text { - } & \text { Ministry of Food and } \\
& \text { Agriculture } \\
\text { - } & \text { Traditional land owners } \\
\text { - } & \text { District Assembly members } \\
\text { - } & \text { Broker }\end{array}$ & $\begin{array}{l}39 \\
48\end{array}$ & $\begin{array}{c}1 \\
5 \\
2 \\
8 \\
4 \\
1 \\
21\end{array}$ & \\
\hline Total & & & & 108 \\
\hline
\end{tabular}

\section{Key informant interviews}

To acquire historical background information about the study area, face-to-face interviews were conducted between 2014 and 2018 with five key informants engaged in large-scale land acquisition and investment in jatropha spaces; 17 individual farmers who were directly affected by the investment abandonment or diversification; five key government officials connected to the project at district levels; 19 traditional landowners and stool land ${ }^{1}$ representatives who had taken part in the land negotiation and acquisition process; 12 Assembly members from the districts affected by investment abandonment or diversification; and three brokers who had played a role in the acquisition of land and agri-investment projects in the study areas.

\footnotetext{
${ }^{1}$ Stool lands are customary lands owned by families or clans that are usually held in trust by traditional leaders known as chiefs, family heads or land priests for the benefits of members of the community.
} 


\section{Focus group discussions}

In order to obtain information efficiently, the interviews were complemented by focus group discussions (FGDs). According to Acocella (2012), FGDs involve group interactions and their heuristic value lies in the depth of interactions that emerge during the debate on a subject matter being researched. The participants in FGDs were mainly farmers (pastoralists and both indigenous and migrant farmers) and employees of jatropha production companies. Three rounds of FGDs were conducted between 2014 and 2018 to explore the direct and indirect impact trajectories of jatropha production and the aftermath of such production. The focus group procedure was consistent across the three study sites. Focus groups that participated in the FGDs included 84 company employees who had been engaged in large-scale land acquisition and investment in jatropha spaces, and 80 farmers who had been directly affected the investment abandonment or diversification. In order to interview respondents directly affected by jatropha investments, investment abandonment or diversification, farmers were sampled based on two criteria, namely must be a local (indigenous or migrant) farmer and a local resident who had lived in the study communities for at least four farming seasons before the commencement of jatropha production. The FGDs had 8-10 participants to ensure greater control of discussion subjects and allow each participant ample time to share their views and insights (Manoranjitham \& Jocob, 2007). Respondents' views obtained through FGDs were used to understand community land use patterns before and during jatropha production.

In Ghana, land in a community that hosts investments is usually used by both the original occupiers (the indigenous landowners) and migrants from other parts of the country who arrive in search of farming or grazing land (Boamah, 2014). FGDs were used to gain insight into the impacts of the investment on these farmers and other community members. That is, farmers whose lands formed part of the land acquired during the large-scale investment, farmers who were present in the selected communities and engaged either in farming alone or had additional economic activity/activities for at least the previous four farming seasons after the land was acquired by the investor, and community members who were not farmers but were directly affected by the large-scale investments.

\subsection{Data analysis}

Data analysis was performed at three levels. The first level involved reviewing global literature on jatropha investment and investment failure, and systematically analysing the literature to shed light on the global trend for investment failure. The second level entailed analysing the primary data using insights from both academic literature and transcripts from qualitative 
primary data. The qualitative data were clustered into themes and a content analysis was conducted to explore complexities and draw patterns that shed light on the thematic issues. Because the interviews were recorded, the use of quotations was part of the analysis. Before the analysis, all data were validated by five key respondents to ensure that the data were true reflections of the issue examined in the study. The third level involved analysing all secondary and primary data by harmonizing the data into a synthesis report and concluding with recommendations towards inclusive sustainable development.

\subsection{Limitations}

Qualitative techniques were used to generate both secondary and primary data. The data analysis made wide use of content analysis in order to descriptively present issues based on the direct perspectives of the informants. However, Choy (2004) noted that combining qualitative and quantitative approaches provides better results than the use of just one technique. The secondary and primary data analysis, however, found support in the theories for this study, making the findings scientifically concrete and somewhat reliable for policy inferences and decision making. Nevertheless, there are some caveats concerning the materials and methods used in the research.

First, the use of purposive and snowballing sampling was essential to help examine the detailed answers received from respondents, especially key informants. But the procedures were very cumbersome and did not allow the drawing of precise and targeted conclusions, as there could be possible biases (Charmaz, 2006). Notwithstanding the extensive use of annual back-and-forth field studies, the data were analysed and interpreted carefully to ensure that the conclusions drawn were consistent and logical.

Second, the field data were collected over an extended period, which helped to reveal several social facts that at first had not been apparent. The data were extensively discussed using content analysis approaches. The use of content analysis was intended to ensure that prevailing issues were grouped under various themes and that discussions were aligned with the themes in a logical manner for a comprehensive understanding of the issues. Despite content analysis presenting a platform for issues to be investigated and analysed, identifying common themes was a tedious process compared to using a quantitative approach to data analysis. Although adequate data were obtained to answer the research questions, the use of field research made the documentation of observations challenging, and generalization of the research findings would be questionable. However, the research supported the field study with secondary 
data, which is necessary to have deeper understanding of the perception of people and processes.

Third, in order to obtain information from some key informants efficiently, key informant interviews were complemented by focus group discussions (FGDs). According to Acocella (2012), FGDs involve group interactions and their heuristic value lies in the depth of interactions that emerge during the debate on a matter being researched. The FGDs provided abundant information and offered an opportunity for the researcher and field assistants to seek clarification. However, FGDs were difficult to control in some cases, and getting some key participants to engage in them was quite difficult. However, the research overcame the challenge by validating information from different focus groups with the same concerns.

\section{Background literature}

The changes that have taken place in jatropha spaces were analysed, with a focus on the ecological, economic, social and political aspects of former jatropha spaces. These four dimensions have been shown in the literature mainly in relation to what the ecological consequences are, what has happened in terms of socioeconomic change and the social wellbeing of affected local land users, what the implication are for social identity and local citizenship, and what the changes are in the political relations and power structure in jatropha investment spaces. Taking these dimensions as the starting principle, this section provides brief reviews, arguments and aspects of the ecological, economic, social and political dimensions in the global space of jatropha large-scale investment.

\subsection{Ecological consequences}

The land investment caused substantial ecological alteration and landscape transformation in host communities (Acheampong and Campion, 2014). Ecological issues are interlocked with social, economic and political issues; thus, ecological alterations affect community access and claims to forest resources, which usually serve as the main livelihood of most community land users (Hughes et al., 2011; FOODSPAN, 2012). For instance, Kugelman and Lavenstein (2009) observed that in the sub-Saharan region of Africa, two thirds of all land is leased for biofuel production, specifically jatropha. Most of these lands are part of the landscape of either natural vegetation or farmlands, which have been relied upon by rural communities for decades (Schut et al., 2010; Polack et al., 2013). The landscape alteration happens because the quest to meet global energy needs justifies jatropha production (Cotula et al., 2008), and investors' 
commercial decisions are usually informed by relevant information and knowledge concerning the prospects of returns on their investments. As such, investors see their investments as more important than the ecological derivations communities require for successful existence (e.g. Daszko \& Sheinberg, 2005).

When a jatropha investment fails, the host communities are not able to regain their original ecological state and vibrancy. In intense situations, such communities could die off especially if the ecology remains the mainstay of the local people (Miller, 2011). Therefore, measures are needed to help safeguard the environment. If such measures are taken, land offered to investors will then strengthen local livelihood conditions and shape ecological situations in a way that helps communities to retain their authenticity and benefit from investments. The consequences of ecological alteration caused by the aftermath of large-scale jatropha cultivation are yet to be well understood. Therefore, detailed research is needed to unravel the transformational complexities regarding ecological environment integrity and its related socioeconomic implications.

\subsection{Socioeconomic change and wellbeing}

One reason for the World Bank's (2011) initial support for large-scale jatropha investments was the positive economic impacts that such investments were perceived to have on host communities. It was expected that such investments could promote economic growth and enhance local livelihoods through job creation. There is, however, opposition to the World Bank's perspective. For instance, the Oakland Institute and the United Nations have emphasized that such large-scale investments are detrimental to local economic situations through the displacement of people and the subsequent dispossession of livelihood assets (De Schutter, 2009; Wolford et al., 2013). Horne and Mousseau's (2011) observation of large-scale investment shows that gains from investment largely benefit outsiders rather than insiders, whose lands are taken away from them. Subsequently, various actors, including the World Bank, have come to recognize that large-scale investments can be detrimental and deprive local communities of economic progress, but can be beneficial if inclusive and responsible business models are adopted.

The World Bank, FAO and other organizations therefore called for 'responsible business conduct' so that economic benefits can be distributed to local people. In this sense, economic inclusivity in business conduct on the part of investors is the central focus, and commercial investors are expected to include business models such as out-grower schemes to help improve the livelihoods of affected individuals (Schoneveld, 2013). Inclusive business 
models have been mainly premised on contract farming, inputs supply and other support arrangements. This has been somewhat beneficial compared to investments without such arrangements, although there are various setbacks, such as unfair contractual provisions and changes in market prices, which create unintended results that are contradictory to the results of development planning and implementation.

\subsection{Social identity and local citizenship}

Land has social connotations as a 'common pool resource' that can be used to strengthen social capital (Berry, 2009). Therefore, land acquisition that alters ecological and economic contexts creates social implications. In Ghana, this also has implications for social stability and identity, as lands in communities that host investments are usually used by both the indigenous population and migrants (Boamah, 2014). The social identity status is defined through the concept of local citizenship, which plays a significant role in local rights dynamics and access to and utilization of local resources such as land (Sikor \& Lund, 2010).

When land investment takes land away from its users, indigenous people can use their social identity, underpinned by customs and traditions, to take over alternative suitable lands for their livlihoods (Sikor and Lund, 2010). On the other hand, migrants are usually neglected and simply displaced. In the Ghanaian context, indigenous populations are recognized as the first settlers of a community, as they have a solid understanding and institutional backing that their ancestors were the first to settle in a particular community (Boamah, 2014). In other words, indigenous peoples are sometimes referred to as first arrivals, first settlers or landowners. The migrants are seen as newly arriving settlers in a community, and are sometimes referred to as local foreigners, strangers, outsiders or aliens in relation to a particular community, even though they may be citizens of Ghana (ibid). Because this group of people are seen as strangers, their rights and access to land are governed by a set of rules and regulations that need to be followed; failure to comply is likely to lead to alienation.

In the process of the re-establishment of land connections, competition between indigenous peoples and migrants usually arises (Berry, 2009), and this tends to create and widen social fragmentations in host communities. The competition is usually triggered by local identity status and resource protection (Boamah, 2014) and employment protection in favour of indigenous people. In addition, Chauveau (2006) points out that reasons for impeding migrants' access to land by indigenous people are also induced by the possibility that migrants will come to control the lands through gradual dominance and the possibility of wealth creation. In most cases, the gradual fragmentation of host communities leads to migrants' mobility and 
connection to land resources in other communities. This manifestation transforms social relationships in a manner that prevents vibrant local connectivity.

According to Boni (2006), when migrants' lands are taken for large-scale investment purposes, the indigenous people exploit them by charging high rents for alternative lands. Since migrants are vulnerable, they usually do not protest but put up with the maltreatment, or move away from the community to other areas. In the context of changing investments in Ghana, the substantial but often unpredictable transformations in relation to the dynamics of local citizenship identity and its complex manifestation at the community level have not been subject to extensive scrutiny in the current debates on large-scale land-based investment.

\subsection{Political relations and power structure}

Ecological/environmental sustainability, economic development and social inclusivity are underpinned by the politics of the changing nature of power relations in the process of land investments. In communities that host large-scale land investments, several actors are involved in the acquisition of land; these include traditional leaders (chiefs), elite brokers, local government officials and land users, who are mainly migrant farmers. In Ghana, chiefs are recognized as having the legitimate power to lease out lands for commercial projects (Tsikata \& Yaro, 2014). In most instances, chiefs have been blamed for the negative attributions associated with land grabbing (Knobloch-Westerwick \& Taylor, 2008; Hood, 2011). ObengOdoom (2012) has shown that, in tandem with the negative outcomes, land grabbing in Ghana has led to the disenfranchisement of community members' rights to land resources in a way that such rights are transformed and replaced by property rights usually established by investors through land lease.

In the case of negative attributions of land grabbing, chiefs have therefore been blamed for such outcomes (Antwi-Bediako, 2018). Nevertheless, other actors such as state officials and land brokers, who are usually involved in such acquisition processes, have remained hidden from the sight of blamers such as the media, researchers and NGOs (ibid). Investors involved in large-scale investments usually go through the legitimate process through consultation with key state institutions and local actors that, as indicated by Bryson (2004) and Poveda and Young (2015), help investors to gather support from powerful actors to utilize their acquired lands, whether or not it affects local users.

In relation to blame games associated with land grabbing, Berry (2009) reiterated that chiefs are forced to give out large areas of land to investors in their bid to establish the boundaries of their land and to claim legitimate power over it. This situation is very common 
in sub-Saharan Africa, where there is no formal recognition of boundaries of lands, and nonpermanent features such as valleys and rivers are used as boundaries (Antwi-Bediako, 2018). The intensity of land grabbing can also be attributed to the existence of elite brokers who persuade chiefs to lease land to them and then re-lease it to investors at a huge profit (Wily \& Hammond, 2001). In the context of investments trajectory, especially in the aftermath of jatropha investment, unpredictable transformations signifying complex manifestations of power relations amongst land users, landowners, land brokers and other major land stakeholders have not received extensive scrutiny in the current scholarly debates.

\subsection{Jatropha space as an open-ended socioecological system}

Jatropha space can be conceptualized as an open-ended socioecological system, because the investments are generally driven by uncertainties, randomness and unpredictable events. Thus, jatropha investment, investment failure and changing investment are always accompanied by uncertainties induced by the cause-effect relationship with their associated challenges because of the human errors made in planning and implementing development interventions, and the reality of inherent complexities, to the extent that unintended effects are unavoidable, even were it possible to plan and implement a perfect development intervention (Koch \& Schulpen, 2017; Keijzer \& Lundsgaarde, 2017). The uncertainties, randomness and unpredictable events driven by investment implementation and its aftermath often create knowledge gaps that need to be filled by research. To close the knowledge gap, especially concerning the aftermath of investment failures, it is good to research the characteristics of jatropha spaces as open-ended socioecological systems. Jatropha investment space as an open-ended socioecological system has thus exposed the inherent need to explore the unavoidable complexities revealed by this research.

\subsection{Conclusion}

This chapter has pointed out that most research stops when the investment failure begins. To the best of my knowledge, little research has been done beyond the post-failure moments. Thus, in order to understand the dynamics of development trajectories in major jatropha investment spaces and to learn about what changes the investment and its failure have brought to the space, the ecological, economic, social and political discourse in the three case study areas is analysed in the following chapters, which show various forms of development trajectories and complexities from before large-scale investment conception to the post-failure regime. It is thus important to ascertain how investment and post-investment can trigger these dynamic complex 
relationships within these investment spaces conceptualized as open socioecological systems. Uncertainties and complexities are inevitable outcomes of any investment and post-investment, but the source and degree of complexities tend to create impacts that are revealed by this dissertation.

\section{Dissertation structure}

The remainder of this dissertation is structured as follows.

Chapter 2. Global investment failures and transformations: A review of the boom and

\section{bust of jatropha spaces}

This chapter explores how the cultivation of jatropha has spread around the world and had different impacts in different countries. The focus is on six former jatropha investment spaces in six countries, namely Mexico, China, Mozambique, India, Ethiopia and Ghana. The exploration reveals the different dynamics of jatropha investments in the six countries by showing how the investments failed to meet national development expectations.

\section{Chapter 3. The case of Kobre: From jatropha to abandonment}

This empirical chapter provides an in-depth analysis of the creation of impact complexities in Kobre during and after jatropha investment. The case shows how the investment and investment abandonment brought new challenges to local development.

\section{Chapter 4. The case of Agogo: From jatropha to maize}

This empirical chapter shows how the trajectory from jatropha investment to investment change, exacerbated impact complexities in the Agogo Traditional Area. The case shows the dynamics of impacts during and after jatropha investment failure in the area.

\section{Chapter 5. The case of Lolito: From jatropha to rice}

This empirical chapter focuses on the creation of impact complexities in the Lolito area during and after investment failure. The case shows various impact dynamics of investment failure and change in the jatropha space of Lolito.

Chapter 6. Synthesis: Towards inclusive sustainable development after investment failures 
This chapter synthesizes the study findings of the three cases, revealing a common trend of local livelihood and landscape transformation, and some differences in local dynamics regarding tenure and conflicts. The chapter also contextualizes the inclusive sustainable development approach that is needed to help align the development needs of investors and local communities, such that there are no trade-offs within the three pillars of inclusive sustainable development, namely economic development, environmental sustainability and the social wellbeing of people

\section{References}

Acheampong, E., \& Campion, B. B. (2013). Socio-economic impact of biofuel feedstock production on local livelihoods in Ghana. Ghana Journal of Geography, 5, 1-16.

Acheampong, E. \& Campion, B. B. (2014). The Effects of Biofuel Feedstock Production on Farmers' Livelihoods in Ghana: The Case of Jatropha curcas. Sustainability 2014, 6, 4587-4607.

Acocella, I. (2012). The focus group in social research: advantages and disadvantages. Quality \& Quantity, 46(4), 1125-1136.

Ahmed, A., Campion, B. B. \& Gasparatos, A. (2019). Towards a classification of the drivers of jatropha collapse in Ghana elicited from the perceptions of multiple stakeholders. Sustainability Science, 14(2), 315-339.

Ahmed, A., Campion, B. B. and Gasparatos, A. (2017). Biofuel development in Ghana: policies of expansion and drivers of failure in the jatropha sector. Renewable and Sustainable Energy Reviews, 70, 133-149.

Anseeuw W, Lay J, Messerli P, Giger M. and Taylor M. (2013). Creating a public tool to assess and promote transparency in global land deals: the experience of the land Matrix. Journal of Peasant Studies, 40, 521-30. http://dx.doi.org/10.1080/ 03066150.2013.803071.

Anseeuw, W., Boche, M., Breu, T., Giger, M., Lay, J., \& Messerli, P. K. Nolte (2012): Transnational Land Deals for Agriculture in the Global South. Analytical Report based on the Land Matrix Database. CDE/CIRAD/GIGA, Bern/Montpellier/Hamburg.

Antwi-Bediako, R. (2018). Chiefs and nexus of challenges in land deals: An insight into blame perspectives, exonerating chiefs during and after Jatropha investment in Ghana. Cogent Social Sciences, 4(1), 1456795.

Antwi-Bediako, R., and Mohammed, A. (2017). Indigenes Hegemonic Power Over Migrants Citizenships: The Role of Largescale Agri-Investment in Ghana in Local Citizen 
Transformation

https://www.uneca.org/sites/default/files/uploadeddocuments/LPI/CLPA_2017/Presen tations/richmond_antwi-bediako_conference_paper.pdf

Antwi-Bediako, R., Amsalu, A., Kinfu, M., Timko, J.A., \& M. Hoogland (2012): Country Research Report-Ethiopia: Assessing the socio-economic implications of industrial biofuel plantations: Repercussions of Jatropha curcas on rural land use alienation and conflict escalation in Ethiopia. https://www.nwo.nl/en/research-and-results/researchprojects/i/51/6151.html

Antwi E, Bensah EC, Quansah DA, Arthur R. and Ahiekpor J. (2010). Ghana's biofuels policy: challenges and the way forward. International Journal of Energy and Environment, 1(5): 805-14.

Berry, S. (2009) 'Property, authority and citizenship: land claims, politics and the dynamics of social division in West Africa. Development and Change 40(1): 23-45

Boamah, F. (2014). How and why chiefs formalize land use in recent times: the politics of land dispossession through biofuels investments in Ghana, Review of African Political Economy, 41(41), 406-423.

Boamah F. (2014). Imageries of the contested concepts 'land grabbing' and 'land transactions': implications for biofuels investments in Ghana. Geoforum; 54: 324-34. http://dx.doi.org/10.1016/j.geoforum.2013.10.009.

Boni, S. (2006) 'Indigenous Blood and Foreign Labor: The Ancestralization of Land Rights in Sefwi (Ghana)', in R. Kuba and C. Lentz (eds) Land and the Politics of Belonging in West Africa, pp. 161-86. Leiden: E.J. Brill.

Borras Jr, S. M., McMichael, P., \& Scoones, I. (2010). The politics of biofuels, land and agrarian change: editors' introduction. The Journal of peasant studies, 37(4): 575-592.

Bos, H.L., Slingerland, M.A., Elbersen, W. and Rabbings, R. (2008). Beyond Agrification; twenty years of policy and innovation for non-food application of renewable resources in the Netherlands. Biofuels Bioprod. Biorefining, 2: 343-357

Bryson, J. M. (2004). What to do when stakeholders matter: Stakeholder identification and analysis techniques. Public Management Review, 6(1), 21-53. https://doi.org/10.1080/14719030410001675722

Campion, B. B., \& Acheampong, E. (2014). The chieftaincy institution in Ghana: causers and arbitrators of conflicts in industrial Jatropha investments. Sustainability, 6(9), 63326350 . 
Campion, B. B., Essel, G., \& Acheampong, E. (2012). Natural resources conflicts and the biofuel industry: implications and proposals for Ghana. Ghana Journal of Geography, $4,42-64$.

Charmaz, K. (2006). Constructing grounded theory: a practical guide through qualitative analysis. London, United Kingdom: Sage.

Chauveau, J.-P. (2006) 'How Does an Institution Evolve? Land, Politics, Intergenerational Relations and the Institution of the Tutorat amongst Autochthones and Immigrants (Gban Region, Cote d'Ivoire)', in R. Kuba and C. Lentz (eds) Land and the Politics of Belonging in West Africa, pp. 213-40. Leiden: E.J. Brill

Cotula, L., N. Dyer, and S. Vermeulen. 2008. 'Fueling Exclusion? The Biofuels Boom and Poor People's Access to Land.' International Institute for Environment and Development (IIED) and FAO, London. www.iied.org/pubs/pdfs/12551IIED.pdf.

Choy, L. (2014). The strengths and weaknesses of research methodology: comparison and complimentary between qualitative and quantitative approaches. IOSR Journal of Humanities and Social Science, 19(4), 99-104.

Daszko, M., \& Sheinberg, S. (2005). Survival is optional: Only leaders with new knowledge can lead the transformation. Transformation, 408: 247-7757.

Deininger, K. and Byerlee, D. (2011). Rising global interest in farmland: can it yield sustainable and equitable benefits? World Bank Publications.

De Schutter, O. (2009). Large-scale land acquisitions and leases: A set of core principles and measures to address the human rights challenge. Briefing note (Geneva: UN Office of the High Commissioner for Human Rights, 11 June 2009). Development, 92: 1-12.

Edelman, M., Oya, C., \& Borras Jr, S. M. (2013). Global Land Grabs: historical processes, theoretical and methodological implications and current trajectories.

Favretto N, Stringer LC, and Dougill AJ. (2012). Policy and institutional frameworks for the promotion of sustainable biofuels in Mali. Centre for climate change economics \& policy working paper no. 103. London and Leeds.

FOODSPAN (Policy Brief) (2012). 'Land Grabbing, Biofuel Investment and Traditional Authorities in Ghana'. International Food Security Network (IFSN) /ActionAid Ghana (AAG)/ Food Security Policy Advocacy Network (FoodSPAN) Strengthening Civil Society Networking in the International Policy Dialogue for an Increased Food Security Project. Community, Land and Development Foundation (COLANDEF) 
Gasparatos, A., von Maltitz, G. P., Johnson, F. X., Lee, L., Mathai, M., De Oliveira, J. P., \& Willis, K. J. (2015). Biofuels in sub-Sahara Africa: Drivers, impacts and priority policy areas. Renewable and Sustainable Energy Reviews, 45: 879-901.

Geertz, C. (1973). Thick description. The interpretation of cultures, 3-30.

Hood, C. (2011). The blame game: Spin, bureaucracy, and self-preservation in government. Princeton, NJ: Publisher University Press. Retrieved from http://public.eblib.com/ choice/public full record.aspx?p=664551

Horne, F., \& Mousseau, F. (2011). Understanding land investment deals in Africa. Country report: Ethiopia. The Oakland Institute, Oakland CA.

Hughes A.K., Knox A., and Jones-Casey K., (2011). 'Rising Demand for Land and Tenure insecurity in Ghana'. Lesson 2: Pressures on Land from Large-Scale Biofuel Production. World Resources Institute in partnership with Landesa (Rural Development Institute). Funded by the Bill \& Melinda Gates foundation.

Jingura, R.M.; Matengaifa, R.; Musademba, D.; Musiyiwa, K. (2011). Characterization of land types and agro-ecological conditions for production of Jatropha as a feedstock for biofuels in Zimbabwe. Biomass Bioenergy, 35: 2080-2086.

Kant, P., \& Wu, S. (2011). The extraordinary collapse of Jatropha as a global biofuel. Lempert, R.J. (2003). Shaping the Next One Hundred Years: New Methods for Quantitative, Long-Term Policy Analysis; Rand Corporation: Santa Monica, CA, USA.

Keijzer, N. \& Lundsgaarde, E. (2017). When unintended effects become intended: implications of 'mutual benefit' discourses for development studies and evaluation practices Working Paper. Ministry of Foreign Affairs of the Netherlands, and Radboud University, Nijmegen.

Knobloch-Westerwick, S. \& Taylor, L. (2008). The blame game: Elements of causal attribution and its impact on siding with agents in the news. Sage. Retrieved from http://crx.sagepub.com/content/ early/2008/10/07/0093650208324266 doi:10.1177/0093650208324266.

Koch, D. J., \& Schulpen, L. (2017). Unintended effects of international cooperation: A preliminary literature review. In: Paper presented at the unintended effects of international cooperation.

Kothari, C. R. (2004). Research Methodology: Methods and Techniques. New Age International Limited. 
Kugelman M., and Levenstein S.L., (2009). 'Land Grab? The race for world's farmland'. Network, Kenya

Manoranjitham, S. \& Jacob, S.K., (2007). Focus group discussion. Journal of the Nursing Association of India, 98(6), 125-127

Miller, C. (2011). 11. The Future of the Basin: Thriving or dying communities? Basin Futures, 193.

Morris, M., Binswanger-Mkhize, H. P., \& Byerlee, D. (2009). Awakening Africa's sleeping giant: prospects for commercial agriculture in the Guinea Savannah Zone and beyond. The World Bank.

Obeng-Odoom, F. (2012). Neoliberalism and the urban economy in Ghana: Urban employment, inequality, and poverty. Growth and Change, 43, 85-109.

Ohimain E.I. (2013). Can the Nigerian biofuel policy and incentives transform Nigeria into a biofuel economy? Energy Policy, 54: 352-9. http://dx.doi.org/ 10.1016/j.enpol.2012.11.051

Paek, H.J., Reid, L.N., Jeong, H.J., Choi, H. and Krugman, D. (2012). 'Five decades of promotion techniques in cigarette advertising: A longitudinal content analysis', Health Marketing Quarterly, 29(1): 1-17

Polack, E., Cotula, L., and Côte, M. (2013). 'Accountability in Africa's Land Rush? What Role for Legal Empowerment?' http://pubs.iied.org/pdfs/12572IIED.pdf

Portner, B., Ehrensperger, A., Nezir, Z., Breu, T. and Hurni, H. (2013). Biofuels for a Greener Economy? Insights from Jatropha Production in Northeastern Ethiopia. Sustainability, 6: 6188-6202; doi:10.3390/su6096188

Poveda, C. S., \& Young, R. (2015). Potential benefits of developing and implementing environmental and sustainability rating systems: Making the case for the need of diversification. International Journal of Sustainable Built Environment, 4(1): 1-11

Schoneveld, GC. (2014). The geographic and sectoral patterns of large-scale farmland investments in sub-Saharan Africa. Food Policy, 48: 34-50. http:// dx.doi.org/10.1016/j.foodpol.2014.03.007.

Schoneveld GC. (2013). The governance of large-scale farmland investments in sub- Saharan Africa: a comparative analysis of the challenges for sustainability. Delft: Eburon Books.

Schoneveld, G. C., German, L. A. and Nutakor, E. (2011). Land-based investments for rural development? A grounded analysis of the local impacts of biofuel feedstock plantations in Ghana. Ecology and Society, 16(4). 
Schut, M., Slingerland, M. and Locke, A. (2010). Biofuel developments in Mozambique. Update and analysis of policy, potential and reality. Energy Policy, 38(9): 5151-5165

Sikor, T., \& Lund, C. (eds). (2010). The politics of possession: Property, authority, and access to natural resources. John Wiley \& Sons.

Timko, J.A., Amsalu, A., Acheampong, E. and Teferi, M.K. (2014). Local Perceptions about the Effects of Jatropha (Jatropha curcas) and Castor (Ricinus communis) Plantations on Households in Ghana and Ethiopia, sustainability, 6, 7224-7241. doi:10.3390/su6107224.

Timko, J. A. (2014). An analytical framework for assessing the impacts of jatropha curcas on local livelihoods. Conflicts over Natural Resources in the Global South-Conceptual Approaches, 173.

Tsegaye, W. and Glantz, M.H. (2011). Biofuels in Africa: A Path Way to Development, Occasional Paper No. 43; International Research Center for Energy and Economic Development: Boulder, CO, USA, 2009.

Tsikata, D., \& Yaro, J. (2011). Land Market Liberalization and Trans-National Commercial Land Deals in Ghana since the 1990s. Paper presented at the International Conference on Global Land Grabbing, Retrieved from http:// www.iss.nl/fileadmin/ASSETS/iss/Documents/ Conference papers/LDPI/33_Dzodzi_Tsikata_and_Joseph_Yaro.pdf.

Tufa, F., Amsalu, A., \& Zoomers, E. B. (2018). Failed promises: governance regimes and conflict transformation related to Jatropha cultivation in Ethiopia. Ecology and Society, 23(4).

Verschuren, P. (2003). Case study as a research strategy: some ambiguities and opportunities. International Journal of Social Research Methodology, 6(2): 121-139

Von Maltitz, G., Gasparatos, A., \& Fabricius, C. (2014). The rise, fall and potential resilience benefits of Jatropha in Southern Africa. Sustainability, 6(6): 3615-3643.

Wily, L. A., \& Hammond, D. (2001). Land security and the poor in Ghana: Is there a way forward? A land sector scoping study. Summary commissioned by the UK Department for International Development (DFID) Ghana's Rural Livelihood Programme

Wolford, W., Borras Jr, S. M., Hall, R., Scoones, I. and White, B. (2013). Governing global land deals: The role of the state in the rush for land. Development and change, 44(2): 189-210.

World Bank (2011). Rising global interest in farmland: can it yield sustainable and equitable benefits? World Bank, Washington, D.C., USA. 
Yin, R.K. (2003). Case study research: Design and methods, Applied social research methods series, Sage, Thousand Oaks, CA, Inc.

Yin, R.K. (2006). Case Study Methods. Available at www.sagepub.com/repositor

Yin, R. K. (2017). Case study research and applications: Design and methods. Sage publications.

Yusuf SA. (2012). The Biofuel energy alternative. West Africa insight. January: 2013 crude refining. Available online at: 〈http://www.westafricainsight.org/articles/PDF/ 225〉 [accessed on 04.04.15]. 


\title{
CHAPTER 2
}

\section{Global investment failures and}

\author{
transformations: A review of the boom
} and bust of jatropha spaces

An earlier version of this chapter was published in Sustainability 2019, 11, 3371; doi:10.3390/su11123371. Richmond Antwi-Bediako ${ }^{1 *}$, Kei Otsuki ${ }^{2}$, Annelies Zoomers ${ }^{2}$, Aklilu Amsalu $^{3}$ 


\begin{abstract}
There has been increased global interest in large-scale jatropha for the past few decades, and this has resulted in investments in the crop in many developing countries. Many saw jatropha as a green fuel that could possibly be an alternate fossil fuel, the combustion of which has adverse implications for climate change. However, jatropha investments have failed to meet global expectations, leading to the unexpected social, environmental and economic transformation of the investment spaces. The present research synthesized the jatropha investment complexities and transformations in six former major jatropha investment destinations across the world - Mexico, India, China, Ethiopia, Mozambique and Ghana - by using qualitative conventional content analysis. The findings show that the jatropha boom and bust contributed to global transformations in all the countries studied, where promoters including the central governments and private investors - adopted a 'wait-and-see' approach and had positive expectations. The research also found that the intended goal of establishing global jatropha investments to serve as an alternative source of fuel failed because of the unexpected complexities of the hype, which focused on the deferment option or the 'wait-andsee' approach. Unmet expectations have led to a shift of attention from jatropha to other crops (often food crops) or total abandonment. The findings of the research provide meaningful justification for policymakers and decision makers in the development space to tacitly reflect on and appraise new investment initiatives or interventions before endorsing them.
\end{abstract}

Keywords: biofuel; jatropha; investment; transformation; government; corporate; hype; bust 


\section{Introduction}

In the first decade of this century, investments in large-scale jatropha production gained prominence around the world. This was driven by the high price of oil on the international market, a desire to ensure energy security and the quest to reduce emissions of harmful gases that lead to climate change (Sulle \& Nelson, 2009). According to Openshaw (2000), jatropha was favoured by investors because the crop has many attributes, multiple uses and great potential for meeting global needs. For instance, the by-products of jatropha can be transformed into a fuel source (Achten et al., 2010) and used for preparing soaps and candle wax (Achten et al., 2007). The crop can also be used to impede soil erosion caused by rainwater, as fencing and to reclaim degraded lands (Achten et al., 2008); Openshaw, 2000). Driven by these expectations, governments, multilateral organizations and investors piled into jatropha (Bassey, 2008).

According to Jingura et al. (2011) and Tsegaye and Glantz (2011), as a result of the growing global demand for climate-friendly transport fuels, countries in Africa (e.g. Ghana, Ethiopia and Mozambique), Asia (e.g. China and India) and South America (e.g. Mexico and Brazil) became targets for large-scale land acquisition and investment in biofuels. Hence, governments in Africa, Asia, and South America collaborated with countries - notably Brazil and India - that have considerable experience in biofuel development to transfer technology to their biofuel sectors, and then invested in cultivating biofuel crops such as jatropha, sugarcane, teak and oil palm (Tsegaye and Glantz, 2011). The governments' interest was further heightened by the claims that jatropha could improve local livelihoods, alleviate poverty and kindle local development (Timko, 2014). Jatropha investment took the centre stage of agricultural investments in many countries in the global South due to its immense contribution to socioeconomic development (Bosch \& Zeller, 2013; FAO, 2013).

Jatropha originated in Mexico, where it was first used by the Olmeca people some 5000 years ago (Dias et al., 2012) for medicinal purposes (Leonti et al., 2003). It was then grown in Brazil and some parts of Central America. According to Henning (2003), Portuguese seafarers distributed jatropha through the Cape Verde Islands to Africa and Asia. Openshaw (2000) indicates that the potential of jatropha as an oil-producing crop has long been acknowledged in the form of demonstration farms in countries such as Nepal, Zimbabwe, Mali and Brazil for the utilization of the oil. One of the first instances of the wide-scale productions of jatropha was the Austrian-Nicaraguan project instituted in 1990. This project failed, however, as investors found it to be unprofitable (Noueira, 2004). Interest in energy security and climate change 
concerns reignited interest in jatropha in the early 2000s. International funding bodies started to robustly support investors to invest in jatropha (Bassey, 2008; Bassey, 2009) in anticipation of ensuring sustainable energy security whilst having a positive impact on climate change mitigation (Hill et al., 2006). Jatropha is argued to be a 'marvellous crop' with huge potential for economic growth (Openshaw, 2000) and environmental management attributes (Openshaw, 2000; Achten et al., 2010), since it thrives even on less productive land because it does not require much water and or compete for nutrients with other crops (Graham et al., 2014).

During the 2010s, many studies looked at the effects of large-scale jatropha investments on the environment and socioeconomic development (Bosch \& Zeller, 2013; FAO, 2013; FAO, 2012; Hughes et al., 2011). The findings from these studies are mixed. On the one hand, Bosch and Zeller (2013) and the FAO (2012) found that such investments enhanced employment opportunities, improved biodiversity and increased revenues in the host communities. On the other hand, Schoneveld et al. (2010) and Hughes et al. (2011) provided evidence to suggest that the investments led to impoverishment, since households' access to non-timber forest products, which are often considered as common-pool resources, is curtailed by such investments. International NGO Action Aid (2009) also found that jatropha investments had unintended consequences for total food production and increased poverty in investment-centred communities.

These revelations, together with the quest to deal with energy poverty and climate change, motivated governments to allow and support large-scale jatropha investments without sound preparation and arrangements in terms of studies on available and suitable lands, the legal incorporation of social and economic benefits, and conceptualized scientific studies. Many of the countries did not have legal mechanisms to protect the interest, rights, welfare and livelihoods of their rural populations (Cotula et al., 2008). Even during the jatropha investment boom, Skutsch et al. (2011) and Birega (2008) confirmed their doubts about jatropha in terms of its potential to boost Africa's rural development. The jatropha hype without commensurate arrangements for its investments led to poor development outcomes, including negative environmental implications, land alienation, rural livelihood loss, food insecurity, conflict and high investment losses.

According to Timko et al. (2014) and Hamenoo (2014), the outcomes of initial jatropha investments have been negative for local land tenure systems, food production and livelihoods. The annual output of farmers has declined due to their use of parcels of land that were smaller than the ones they had access to before the large-scale jatropha plantations were established (Aha \& Ayitey, 2017). However, little has been discussed about the relationship between the 
initial drivers of jatropha investments - which were intended to do good - and the environmental and socioeconomic development outcomes of the investments and transformation patterns after the jatropha investment failures, and how and why the jatropha investments failed to generate the expected positive environmental and socioeconomic development outcomes, and what prospects the land had for future investments.

This chapter presents a critical review of articles on the boom and bust of jatropha, most of which were derived from the special issue of Sustainability titled 'Global Jatropha HypeDrivers and Consequences of the Boom and Bust of a Wonder Crop'. It is a review and a synthesis of the jatropha investment transformations and the drivers influencing jatropha investment initiatives, government-driven initiatives and private sector-driven initiatives impacting on the production approaches of jatropha investment, and how the transformation influenced the environmental, social and economic systems in six former major jatropha investment destinations, namely Mexico, India, China, Ethiopia, Mozambique and Ghana.

\section{Transformation and investment debates}

Transformation theories are not entirely new in scientific research, as they have long been identified (Farazmand, 2003) in other fields, but they are new in land grab and investment debates. The term transformation can elicit associations ranging from organizational change and leadership, to land-based investment intervention changes. According to Deming (1993) and Daszko and Sheinberg (2005), transformation is like a never travelled journey and, as such, its destination is unknown, tentative and cannot be predicted, but welcomes new learning and actions based on new discoveries. Transformations in land spaces are a phenomenon of uncertainties surrounded with development decision-making at any given time (Murphy \& Hallinger, 1992). Several models of decision making under uncertainty have been proposed, including modern investment policy decisions (Sarasvathy \& Dew, 2005). In recent times, investment hypes like jatropha have been driven by uncertainties, randomness and unpredictable events (Gleick, 1987; Wheatley, 1999), and some uncertainties that occur in transformations are expected. Therefore, in the phenomenon of uncertainties in investment trends in such transformations, nothing happens out of nowhere, but is induced by cause-effect relationships and their associated challenges.

In some instances, unexpected events are triggered by mere chance or/and an accident with or without recourse to modern investment and therefore adds the risk element to modern investment. Even though the future outcomes of transformations are unknown, predictions such as goal setting are key in modern investment. According to Deming (1993), predicting without 
information and knowledge is merely guessing, which leads to crisis-related risk. Muys et al. (2014) support Deming's assertions and postulate that policy measures towards the adoption and promotion of new initiatives should hinge on multiple, interconnected and viable data. Therefore, interconnected and viable data to predict policies and develop policy are key to promoting new initiatives. Lempert (2003) contends that a single policy implementation is usually insufficient to tackle a particular development problem and risk. Farazmand (2003) highlights that the persuasive nature of risks associated with crisis in these contemporary times is worse than ever before. The outcomes of modern large-scale investments include land grabbing, which significantly transforms property relationships and social relationships of production (Brenner, 1982; Kenney-Lazar, 2012). Kenny-Lazar (2012) also postulates that modern large-scale investments may result from a variety of agrarian problems, such as land degradation, larger firms out-pricing smallholder crops on the market or the availability of more lucrative off-farm employment, which before the investment could not be predicted most probably due to the lack of an indigenous people's knowledge of a system. Keijzer and Lundsgaarde (2017) do not consider whether unforeseen or unintended changes occurred, but instead focus on two reasons why they occurred, namely because the occurrence of unintended changes linked to human errors made in planning and implementing development interventions, and because reality is inherently complex to the extent that unintended effects will be unavoidable even were it possible to plan and implement a perfect development intervention (Koch \& Schulpen, 2017).

\section{Methodology}

To understand the outcomes of how jatropha investments transformed global, national and local systems socioeconomically and environmentally during and after the jatropha hype, the existing literature was reviewed using qualitative conventional content analysis. This was done through a case study design involving the six countries that underwent major jatropha development in order to describe the pattern of transformation in terms of undesired socioeconomic and environmental outcomes. The development was intensified in these countries through a combination of government and corporate interventions. Since jatropha was abandoned almost a decade ago in these countries, no relevant studies have been conducted to understand the transformational complexities of endorsing other crops. It was therefore imperative to integrate the diverse unintended development consequences and transformational complexities of jatropha. The use of content analysis helped to provide in a pragmatic manner insightful knowledge and understanding (Downe-Wamboldt, 1992) of investment transformation, which 
has scant theoretical bedrocks and literature in the land grabbing discourse. Based on the current debate on large-scale biofuel investments and literature on the matter (Downe-Wamboldt, 1992), Kondracki and Wellman (2002) suggest that the use of qualitative conventional content analysis is requisite, and hence justify the use of this type of content analysis.

Secondary data collected through a review of the special issue of Sustainability mentioned above were subjected to a conventional content analysis to derive major themes in each country by capturing the key thoughts on transformation in Mexico, India, China, Ethiopia, Mozambique and Ghana (Morse \& Field, 1995; Miles \& Huberman, 1994). Based on the major themes, the findings were organized into a meaningful and logical cluster, as suggested by Patton (2002). The use of a conventional content analysis approach ensured that other relevant research findings could be addressed in the discussion section of this dissertation to inform policy actions and academic thinking in a concretized manner.

\section{Review of country cases: Transformations during the jatropha regime}

A review of country-specific transformations in the jatropha space during the hype reveals how approaches by investment sources transformed socioeconomic and environmental systems. Governments were the major driving force behind investments during the jatropha hype (Banerjee et al., 2017). Government policies led to two main investment approaches- namely government-led and corporate-led investment approaches - which eventually defined the production approach and investment sources as well as the transformations emerging from these approaches (Figure 2.1). In the government-led approach, the government initiated policies and drove the investment implementation, while in the corporate-led approach investors obtained government buy-in to invest and also sought collaboration with the government.

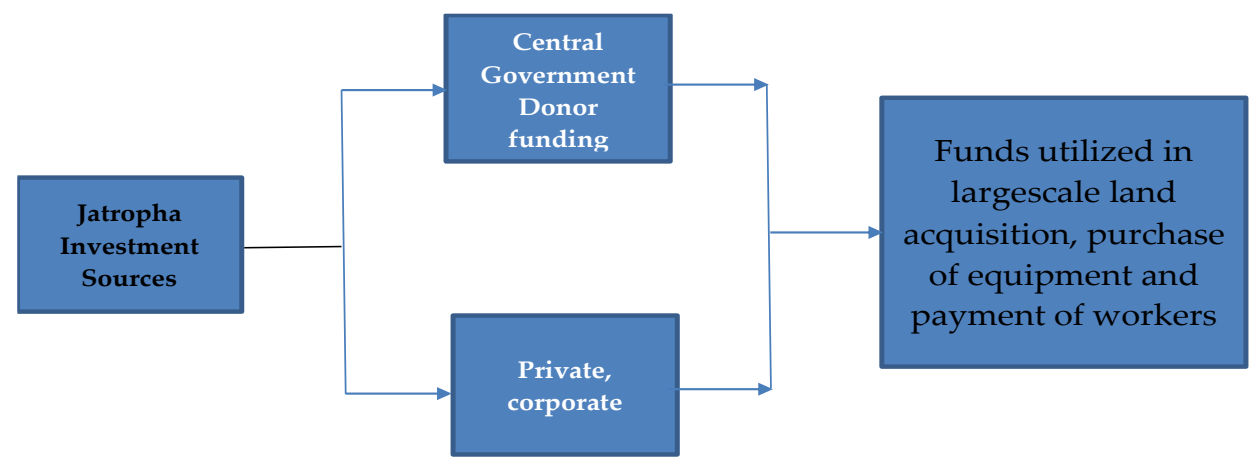

Figure 2.1. Jatropha Investment Sources and Utilization 


\subsection{Transformations in Mexico}

In Mexico, the jatropha investment sources and approaches were government-led. Although Mexico is the 'home' of jatropha, the potential of jatropha for the production of biofuels was unknown until the early 1990s. The renewal of interest in jatropha cultivation started in 2003, when its potential contribution to sustainable energy security sparked global interest in investing in the crop (Sulle \& Nelson, 2009; Birega, 2008). The Mexican government enacted a national biofuel law - the 2008 Bioenergy Promotion and Development Act - as a quick response to diversify Mexico's domestic energy production, commit to reducing greenhouse gases, rehabilitate and reforest degraded land through the ProArbol programme of CONAFOR (the national forestry commission), enhance rural employment, stimulate rural development, and produce biofuel energy to meet local and global needs (Skutsch et al., 2011; Banerjee et al., 2017; Montero et al., 2015).

The primary purpose of the law, however, was to contribute to energy diversification and the sustainable development of the country's agriculture sector, whilst making Mexico a prominent global centre of biofuel energy and contributing to the global goal of reducing the emission of greenhouse gases (GHGs) (Montero et al., 2015). To sustainably move the 2008 Act agenda forward, the Bioenergy Interministerial Strategy (2009-12) was introduced with the aim of reducing political favouritism in districts that lacked the agronomic requirements for the cultivation of jatropha (Sketsch et al., 2011). The government had the task of obtaining additional energy sources for export (Banerjee et al., 2017; Solomon \& Bailis, 2013), with the expectation of spearheading the future provision of additional energy sources to countries in the North. The aim of the biofuel policy was to enhance competitiveness and open the gate for local people to utilize the economic opportunities associated with biofuel investments.

The government initiated jatropha projects in the state of Chiapas through CONAFOR and provided subsidies to achieve positive outcomes. Later, the states of Colima, Michoacán, Morelos, Oaxaca, Sinaloa and Yucatan also benefited from government subsidies (IICA, 2010; Zamarripa-Colmenero, 2008). The government strategically encouraged jatropha along with other biofuel crops, such as castor and oil palm, that were already known. Jatropha was labelled as the preferred feedstock for biofuel investment (Robinson \& Beckerlegge, 2008). This preference was strengthened by the discovery that jatropha could be successful on marginal lands (Hinojosa and Skutsch, 2011) and the government's intention to increase the country's forest area (Skutsch et al., 2011).

The labour-intensive approach to cultivation was adopted to allow for the engagement of large-scale farmers to enhance their livelihoods through job creation and income provision 
(Skutsch et al., 2011; Rucoba et al., 2012). Both local and foreign private investors and agroindustries were also encouraged to invest in jatropha on a large scale, but the intention of the government was to limit their dominance (Hinojosa \& Skutsch, 2011). The local people were thus made the key actors in jatropha production. Farmers engaged in bean and maize production also turned to the production of jatropha (Rucoba et al., 2012; Valero et al., 2011). Agrobusinesses were involved in the production process, but the local people had a greater platform for jatropha production.

Generally, jatropha was invested in for more than three years in Mexico (Birega, 2008); however, the investment outcomes were poor (Valero et al., 2011). In states such as Michoacán, Veracruz, Chiapas, Quintana Roo and Yucatan, the use of marginal land for the cultivation of jatropha yielded poor returns (Ariza-Montobbio \& Lele, 2010). It was expected that the use of marginal lands for jatropha would not lead to negative implications for food production in the country (Schut et al., 2010), but the switch by bean and maize farmers to jatropha led to falls in the production levels of these crops (Skutsch et al., 2011; Hinojosa \& Skutsch, 2011; Rucoba et al., 2012; Valero et al., 2011). In addition, new diseases that damaged other food crops also affected jatropha production (Rodriguez et al., 2014) and jatropha investment did not have any meaningful impacts on local livelihoods. Although new jobs were created for farmers (Skutsch et al., 2011), they could not obtain adequate and expected incomes from these new jobs.

Valero et al. (2011) highlight that in Chiapas, the motivation of the participants was to earn enough income through the sale of jatropha seeds. This motivation was similar to that of the participants in Quintana Roo (Solomon \& Bailis, 2013; Sweitz, 2018; Chan, 2010). Disillusioned with the investment, some local individuals and agro-industries stopped producing jatropha, and in Chiapas State, the authorities abandoned the jatropha project. Institutions and refinery centres were closed down (Rodriguez et al., 2014) as the production could not lead to a substantial reduction in poverty as proclaimed in many studies, but instead deepened the levels of poverty of its actors (Skutsch et al., 2011).

The environmental implications of jatropha were generally a mixture of positive and negative outcomes (Skutsch et al., 2011). For instance, the jatropha project led to afforestation and reforestation in Yucatan: Skutsch et al. (2011) observed that about 2000 ha and 350 ha were used on two different commercial ranches to expand the forest. However, in Michoacán, the jatropha farmers adopted a shifting cultivation approach, which saw a significant number of farmers clearing the secondary forest on a rotational basis for jatropha plantations. The central government, corporate investors and local farmers were disappointed with the outcome of jatropha in terms of spearheading economic transformation and meeting energy needs (Valero 
et al., 2011). As a result, the National Biofuel Policy shifted its attention from jatropha to other biofuel crop research projects and development (Mexican Bioenergy Network as in GAIN [2012]). Investors have withdrawn their investments and some jatropha lands lie idle, whilst others are being used for food crop production by former jatropha farmers (Rodriguez et al., 2014).

\subsection{Transformations in India}

In India, jatropha investment sources and approaches were government-led initiatives through the government's 2003 declaration on the 'National Mission on Biofuels' (Axlesson \& Franzen, 2010). The global interest in biofuel investments encouraged the Indian government to invest in jatropha (Axlesson \& Franzen, 2010), as in the case of Mexico. It saw jatropha cultivation as a means to improve soil fertility, contribute to the reduction of soil erosion, help in the rehabilitation of lands through greening and create jobs for local people (Axlesson \& Franzen, 2010). Although several biofuel crops (e.g. oil palm, maize and sugar cane) received greater attention from the government, jatropha was ranked as the most preferred biofuel crop because it is easy to cultivate, it grows fast and is hardy, the seeds are easy to collect (they are ready to be plucked before the rainy season), the plants are not very tall but cannot be grazed by animals, the crop is rich in nitrogen and the seed cake is a source of plant nutrients. Based on these attributes, the government realized that the cultivation of the crop could help the country achieve its 20\% blending target (Axlesson \& Franzen, 2010; MNRE, 2008). About 11.2 million ha were needed for the cultivation of jatropha in the country (Axlesson \& Franzen, 2010).

Although the major investor was expected to be the government through its policy which demonstrated the government's total commitment to supporting local actors in jatropha enterprises - the implementation saw local corporate actors and farmers using their financial resources for the cultivation of jatropha (Zafar, 2011). The government policy acknowledged the massive involvement of local people as well as the engagement of private and corporate investment through minimum support price mechanizations, which were proposed in the country's Biofuel Policy (Romijn, 2011). To ensure active and massive local participation in the production of jatropha, the government proposed a special support package for local people who wanted to get involved in jatropha cultivation. This proposed support was quite different from Mexico's case, as the government never promised to directly incentivize local jatropha farmers. In Andhra Pradesh State, the government promoted jatropha through incentives in the form of free seedlings for farmers, a $90 \%$ subsidy for the installation of drip irrigation systems 
and free land preparation under the Food for Work and Assigned Land Development programme (MNRE, 2008). Poor farmers who had been assigned land owned by the government were to be provided with full financial assistance by the government, with $40 \%$ secured as a bank loan for the cultivation of jatropha. In the state of Tamil Nadu, companies and NGOs were encouraged to partake in the cultivation of jatropha. Thus, India's jatropha cultivation involved huge numbers of local participants as well as a few other private entities, which were mainly local companies and organizations due to the government's enticing proposals in its policy.

Axlesson and Franzen (2010) found that in certain parts of India, jatropha was cultivated on productive lands, but still failed. Therefore, it became very complex for stakeholders to explain why such production could not yield enough output. Studies have also shown that jatropha has positive environmental outcomes by reducing the emissions of greenhouse gases (Achten et al., 2010). Jatropha production was perceived to make an insignificant contribution to mitigating climate change (Reinhardt et al., 2007), since in India the number of plants per hectare was unlikely to have an important influence on the uptake of carbon (Zafar, 2011). This revelation support the assertions by Prueksakorn and Gheewala (2006) that the cultivation of jatropha has insignificant adverse impacts on climate change.

However, Indian engagement in jatropha production led to intense pressure on the country's limited water resources, due to the demand for water for irrigation purposes. Although it is perceived that jatropha is a drought-resistant crop, farmers realized that water was needed for positive yields. The government developed a plan to provide financial incentives as well as input to support the production of jatropha by local people (MNRE, 2008). The government's failure to deliver on its promises affected jatropha cultivation and local people were forced to use their limited financial resources for the production process, to the point that they could no longer finance their investments. As a result, they withdrew their efforts.

Additionally, the farmers also had very limited knowledge concerning the cultural practices and maintenance of jatropha plantations. Extension officers failed to periodically visit to educate the farmers on the maintenance practices needed for successful outputs, which also contributed to the disappointing yields. The national biofuel policy failed to provide clear marketing plans for jatropha products such as biodiesel, and there were no communication plans or strategies to ensure the flow of marketing information between farmers and biodiesel producers to ensure sustained demand. This led to the absence of a market for jatropha products and made the jatropha business unattractive for the local farmers to engage in. Thus, instead of jatropha investment contributing to poverty alleviation, it further exacerbated it (MNRE, 2008). 
Axlesson and Frazen (2010) further emphasized that poor cultural practices due to a lack of requisite technical management support from agricultural extension officers paved the way for pests and diseases to attack jatropha crops. In Tamil Nadu State, for instance, the pest attacks were generally mild and could have been tackled with the use of pesticides; however, in a few instances, the attacks were more severe than expected and this adversely affected the growth of the jatropha plants, leading to their forced removal. The common pest identified was the mealy bug, which destroyed several crops.

Jatropha production led to the creation of jobs, but this did not really contribute to advancements in local livelihoods. Issues of land alienation were virtually absent as the government incentivized local farmers to use their own land for the cultivation of jatropha, which in some cases was government land (Axlesson \& Frazen, 2010). The government, investors and community members have abandoned jatropha investment, and some jatropha lands are now occupied by community members whilst others have yet to be touched. The government has shifted its focus on jatropha to a wide array of potential feedstocks, including oil palm and sugarcane, in the hope of producing biofuels at a cost-convenient level (MNRE, 2017).

\subsection{Transformations in China}

Even though the Chinese government was the principal agent for initiating the jatropha investment policies in the country's centrally controlled economic system, jatropha investment sources and approaches leant towards a corporate-led production scheme with close monitoring by the government. According to Li et al. (2014), in 2005 the government took the lead in developing a policy environment to allow for biofuel cultivation, one policy being the 'Renewable Energy Industry and Development Supervision', which supports biofuel plantations through the selection of a better variety of crops. The government's initial attention was geared towards technological research and demonstration projects. Therefore, in 2006 it passed the National Forest Construction Plan, the aim of which was to create about 13 million ha of energy forest by 2020 as well as supply raw materials for the production of about 6 million tons of biodiesel.

In 2007, several plans of action were developed, the most significant of which was the 'Medium-Long Term Development Plan on Renewable Energy', which focused on experimental projects in selected provinces including the cultivation of jatropha and using jatropha as biodiesel feedstock. These projects were presumed to contribute towards achieving 
the yearly target for the utilization of biofuel with an expected increment of 1.8 million litres by 2020 , and the management instruction on financial subsidies supporting crops for energy. In 2011, the Chinese Biofuel Policy on Biodiesel Fuel Blend laid down the aim of blending 2-5\% biodiesel with 95-98\% diesel by 2020. Several governmental bodies were engaged with these policies, including the Ministry of Finance and the Ministry of Agriculture, to promote the development of jatropha production across the country. In Sichuan Province, about 14,667 ha were acquired for jatropha cultivation in 2007. Guanjxi and Yunnan were the other two provinces that were involved in jatropha cultivation in 2007. The concerned ministries came together to coordinate how best the country could invest in jatropha to meet their energy demands and for export (Weyerhaeuser et al., 2007). Furthermore, there were plans to increase the cultivation of jatropha (Weyerhaeuser et al., 2007). The large areas of unproductive land in southwestern China were seen as suitable for jatropha cultivation (Benge, 2006).

The government mainly played a supportive role in jatropha cultivation; the actual funds came from investors. As the government had an interest in enhancing wellbeing and tackling poverty amongst the rural population, the plan was to allow local people to engage in the production of jatropha. Corporate bodies could employ local people and train them in the production process, thus ensuring higher yields and enhancing the living conditions of the local people (Li et al., 2014). Corporate bodies, including foreign investors, and individuals were engaged in jatropha production. Two provinces, Sichuan and Guanjxi, were the predominant centres for the cultivation of jatropha. Corporate bodies employed community members to work as field workers/labourers, as the production approach was to make jatropha production labour intensive to allow for employment generation and the advancement of local livelihoods.

The government was unable to achieve its expectation of meeting the growing energy needs of local people using jatropha. According to Li et al. (2014), poor government support, the limited demand for biofuels produced from jatropha and severe frost led to the withdrawal of corporate investment, which contributed to the poor outcomes. Because of the poor investment outcomes, the corporate entities left without compensating the farmers for their services. In Guangxi, for instance, a private company known as the Guangxi Zhilian Renewable Energy Company was involved in the jatropha investment. The company employed farmers under a contract farming scheme. The company withdrew its investment shortly after beginning operations because it needed subsidies from the central government, which were not forthcoming. During the periods of operation, the companies paid their workers through an investor-government coordinated system. This, however, failed and as a result, the workers' livelihoods did not see massive improvements (Li et al., 2014). It is purported that in some 
countries, the heightened interest in biofuel investment led to dynamics in the land use rights and land tenure security of the local participants (Cotula et al., 2008; Rulli et al., 2013) However, in China, the jatropha investment did not alter land use rights or tenure security (Li et al., 2014). This was because the land used was government-acquired land, and as such, community members were not affected. However, jatropha production and processing expenses made its market value higher than fossil products, affecting demand and profitability. This made the investors lose interest, as the government failed to grant them subsidies, leading to the jatropha bust (Li et al., 2014).

\subsection{Transformations in Ethiopia}

Even though Ethiopia has a centralized controlled economic system, the jatropha investment sources and approaches leant towards a corporate-led production scheme with close monitoring by the government under the 'Open Door Policy' (MoME, 2007; FDRE, 2011; EBDD, 2011; Rahmato, 2011, Portner et al., 2013). During the jatropha era, advanced countries saw Ethiopia as an attractive destination to undertake large-scale investment in biofuel production, particularly in jatropha. Faced with global pressures from foreign-based investors, the government was concerned about how the country could take advantage of the jatropha hype to create a greener economy and produce energy to meet local needs. The government developed the Biofuel Strategy to ensure that its aims would be achieved (Portner et al., 2013). The strategy primarily paid attention to achieving a green economy using jatropha biofuel production as well as to improving agriculture, ensuring natural resource management and alleviating poverty (FDRE, 2011).

Jatropha investment was fuelled by two main forces: the government's quest to secure energy through local production, and the increase in demand for biofuels on the international market (MoME, 2007). In 2006, a British biofuel company (Sun Biofuels) started its jatropha operations in the country. By 2010, Ethiopia had about 83 licensed foreign companies investing in biofuel production (EBDD, 2011). Bossio et al. (2012) found that in 2011, foreign direct investment in jatropha amounted to $50 \%$ of the total foreign investment in the country. A land matrix in 2012 indicated that about 1,360,670 ha had been released for biofuel projects, with more than 700,000 ha being used for jatropha production (ILC, 2011). The global interest and pressure on Ethiopia influenced the government to make two main policy changes: it introduced the Ethanol Blending Policy and made changes to its agriculture development and taxation policies, making the country attractive to foreign biofuel investors. Rahmato (2011) called this latter policy the 'open door policy'. In 2007, the government further developed a 'desperate' 
policy titled the 'Biofuels Development and Utilization Strategy' (MoME, 2007). The policy spelt out the approach to enhance biofuel production and use within the country, and about 23.2 million ha of marginal land was earmarked for commercial jatropha production (Wendimu, 2016).

The major source of investment was foreign investors, who acquired large areas of land for jatropha production, while the government played a facilitating and supporting role (MoME, 2007; EBDD, 2011). The government's flexible and open-door policy led to an influx of foreign investors who acquired large area of land for jatropha production. The corporate investors employed local people to work on the plantations as wage labourers. Some local people were permanent workers whilst others were temporary. The production approach involved the use of both manual labour and machines on the plantations (Von Maltitz et al., 2016).

The government was very interested in ecological integrity, which is why it developed the 'Climate-Resilient Green Economy Strategy'. Jatropha production did not make any significant contribution to a greener economy in Ethiopia after the bust, although Portner et al. (2013) showed that it had great potential to reduce soil erosion and retain water for agricultural production in Ethiopia.

In terms of livelihood benefits, jatropha failed as its production did not make a substantial contribution to positive livelihood transformations. It could not be used to alleviate poverty, which is why Portner et al. (2013) found that for farmers to have benefited economically from jatropha would have required the implementation of measures concerning their workloads, the local processing of seeds, and training programmes and market interconnectedness. The investments led to the alienation of local farmers' land, which had served as their economic asset. Power holders and investors did not respect local land rights, and thus individuals whose farms were on the investors' acquired lands were alienated and this increased poverty in the affected communities (Jingura et al., 2011). Some local communities did not support the jatropha project and/or were promised developmental co-benefits, such as basic infrastructure and employment opportunities.

The findings confirmed the assertion by UN-Energy (2007) that biofuel production, such as jatropha plantations, does not benefit poor farmers, but puts them into 'deeper' poverty. This is why Openshaw (2000) called jatropha a 'poor man's crop'. As regards the impact of jatropha production on food production, the study by Von Maltilz et al. (2016) in Niqel, a jatropha investment destination in Ethiopia, revealed changes in food availability and accessibility due to the income received from the locals' participation in the jatropha production process. According to their study, the changes were mixed. In some areas, food production was 
negatively affected, as farmers using grazing and farmland for rotational farming were alienated. The widespread outcome of jatropha was negative, as investment proved impracticable to continue. Hence, they abandoned their acquired lands, thus allowing local farmers to utilize some areas of the jatropha land for food crops (Von Maltilz et al., 2016).

\subsection{Transformations in Mozambique}

Although Mozambique has a centralized economic system, jatropha investment sources and approaches leant towards a corporate-led production scheme with close monitoring by the government. As indicated by Mataveia (2009), the country is highly dependent on the international market, as it consumes about 700,000 cubic metres of petroleum products annually. During the phase of global forces driving the widespread production of biofuel crops such as jatropha, Mozambique also needed to enhance its energy security and reduce its overdependence on imported oil products. According to Schut et al. (2010), the country's National Biofuel Policy and Strategy (NBPS) was developed in 2009 based on the following motivations: the unstable and volatile nature of oil prices on the world market, biofuel as an alternative energy product to reduce dependence on fossil fuels and emissions of greenhouse gases (GHGs), as well as encourage the use of safe and clean energy in the country (Mataveia, 2009). The policy further emphasized poverty reduction and focused on encouraging privatesector participation through collaboration and networking with the government, ensuring crosssectoral coordination in the country through strengthening inter-institutional collaborations and frameworks comprising ministries, departments and agencies and involving tertiary institutions - notably universities, financial bodies, NGOs and civil groups - in biofuel development. The country further deployed the Kyoto Protocol Mechanisms and other international instruments with the quest to speed up the utilization of green fuels and to make an impact on the environment through the reduction of GHGs (Mataveia, 2009).

The major sources of investment were the central government's coffers and corporate funding. The government established a network with both local and foreign private investors to ensure effective investment in jatropha enterprises in the country (Von Maltitz et al., 2016). The government allowed the private sector to dominate jatropha cultivation, which enabled local people to obtain employment with jatropha companies. The private companies collaborated with the government during the production processes and local people participated in jatropha cultivation on individual farms. The government had the intention to collaborate with tertiary institutions to provide evidence-based information to support the investment (Von Maltitz et al., 2016), but this was unsuccessful. During the production processes, the 
government mainly focused on smallholders and communities by supporting them to cultivate jatropha.

The government showed great commitment to jatropha. Even with poor initial production outcomes in 2007, it encouraged investors to continue the project by providing tax incentives (Slingerland \& Schat, 2014). Regardless of such incentives, jatropha failed as a biofuel crop. The jatropha business was unprofitable, and the farmers withdrew their efforts (Bos et al., 2008). Instead of jatropha becoming a safety net, it became a huge risk venture for local people. Mozambique used large areas of land for jatropha cultivation (Batidzirai et al., 2006; Namburete, 2006; Cuvilas et al., 2010) and issues around land rights and tenure security became a critical development challenge. Aggrieved community members closer to the investment sites did not support the project since their lands were taken from them without their consent. Mozambique also had issues with the influx of diseases and pests (Slingerland \& Schat, 2014), and the long-term adverse effects of these diseases and pests are still unknown.

Van Eijck et al. (2013) noted that jatropha production in Mozambique had mixed impacts on farmers' food production. This is because whilst some community members said that jatropha production had adversely affected their food production, others reported improvements in meeting their food needs. Schut et al. (2010) found that the outputs and income obtained from jatropha production were lower compared to other crops, and thus it was better to utilize the available land to produce cash or food crops instead of jatropha. In terms of job creation, Bos et al. (2008) found that many of the local people were employed by investors during the jatropha investment. The study by Romijn et al. (2014) confirmed that more than 500 permanent jobs were created due to the investment decision in favour of jatropha.

\subsection{Transformations in Ghana}

Jatropha investment sources and approaches in Ghana were similar to those in Mozambique and Ethiopia, where there was corporate-led production with monitoring mechanisms and interest from the government in the form of biofuel policy guidelines and tax incentives. The jatropha investment in Ghana was started by Annuanom Industrial Project Limited (Boamah, 2014). In 2003, it called on the government to consider jatropha investment as an innovative avenue to ensure local development transformation (Brew-Hammond, 2009). Background studies convinced the government to commit its resources to jatropha investments. According to Ahmed et al. (2014), a National Jatropha Project Planning Committee was set up to assist in establishing jatropha plantations in the country. The committee recommended pilot jatropha plantations on unproductive and dormant land in 53 districts over a period of five or six years, 
(Amoah, 2006; Agyekumhene, 2006). The government was expected to lead the jatropha investment initiative by encouraging local farmers to transform their livelihoods positively (Brew-Hammond, 2009). The committee suggested that these farmers should be trained extensively by the Ministry of Food and Agriculture (Energy Commission, 2010) to ensure that they gained knowledge on the agronomy practices of jatropha. A market strategy specified that the government should purchase the farmers' outputs, as the biofuel policy mandated that government-owned vehicles were to run on biodiesel on a minimum of B20 (i.e. a blend of of $20 \%$ biodiesel and $80 \%$ petroleum diesel) (ibid).

Technoserve (2007) showed that the Ghanaian government had two biofuel crops to choose from: oil palm and jatropha. The government chose jatropha and decided to pump funds into its cultivation. Agyekumhene (2006) and Ghana Energy Commission (2005) confirmed that the government was dedicated to jatropha investment because of the huge cost of importing crude oil, which increased from USD 516.8 million in 2003 to USD 816.1 million in 2004. Unfortunately, the intended jatropha project came to a halt when Ghana discovered crude oil in 2007. Therefore, both foreign and local investors were granted the opportunity to invest in jatropha (Iddrisu \& Bhattacharyya, 2015). These investors acquired large stretches of land for jatropha plantations (Schoneveld et al., 2010; Boamah, 2014) through negotiations with the chiefs (Boni, 2006). Energy-focussed civil society groups such as the Kumasi Institute of Technology, Energy and Environment (KITE-Ghana), the Gratis Foundation, and New Energy-Ghana also engaged in jatropha investment, but on a smaller scale with funding support from the United Nations Development Programme. These organizations had an interest in using jatropha to benefit local communities (UNDESA, 2007; Karlson and Banda, 2009).

Jatropha investment in Ghana has generally led to unsatisfactory development outcomes for both investors and local communities. Timko et al. (2014) identified the following in some selected jatropha investment sites in Ghana. First, an average of 22.46 ha of land utilized per farmer were taken over by investors for large-scale jatropha. The takeover of farmers' land was not expected, as the motivation for the push for jatropha was that jatropha could be successful on marginal lands (supported by Hinojosa and Skutsch, 2011). Hence, there was the stance that local farmers would not be alienated from their land (James, 2010). However, most of the largescale production was on productive lands, leading to the alienation of farmers.

Timko et al. (2014) also found that the failure of large-scale jatropha investments had a massive negative impact on the expected infrastructure growth and expansion. Except for the Jimle/Kpachaa investment destination, the jatropha investment communities did not benefit from the investors in terms of infrastructural provisions. This finding is contrary to that by 44 | P a g e 
Brittaine and Lutaladio (2010), namely that jatropha investment could trigger the provision of rural-based infrastructure for local transformation. In many of the jatropha centres, jobs were created, but this did not lead to substantial economic improvements in affected communities. In fact, community members were generally worse off as a result of large-scale jatropha cultivation (Acheampong \& Campion, 2014).

Jatropha investments also led to conflicts of varying types (Acheampong \& Campion, 2014) amongst the various interest groups, including investors, farmers, traditional authorities and government agencies. The conflicts were triggered by the lack of community participation and official notifications of the affected individuals during the periods of jatropha investments; the meagre and inconclusive compensation packages; the lack of transparency in the lease arrangements; the lack of trust in the overall negotiation process for jatropha investments; ambiguous landownership structure; and the lack of alternative productive agricultural lands for dispossessed farmers. Acheampong and Campion (2014) asserted that Ghana's jatropha investment outcomes during the initial stages were indications that large-scale jatropha plantations would not help the country attain the proposed ecological and livelihood benefits from jatropha as widely hyped in the early 2000 s.

\section{Discussion}

This review has shown that none of the former jatropha producing countries carried out scientific studies on the crop before investing in it (Banerjee et al., 2017). The general enticing factors attributed to the crop were enough to lure these countries into investing in it, thus placing huge expectations on the crop as a 'miracle' that would meet most of their development expectations. Indications, including Openshaw's (2000) provisions that jatropha could rapidly spearhead economic growth, provided grounds for countries to start its cultivation. All the cases showed the strong government-corporate relationships, and the motivations of countries were manifested through the initiation of biofuel policies with various levels of targets within a specified period. However, as the biofuel policies of the six reviewed countries hinged on specific investment opportunities in favour of green fuel, the central and common reason for the decision to invest in jatropha without commensurate and proper empirical research work was the quest to become energy autonomous and to create job opportunities for local farmers.

There was no local-level research into the country-specific conditions or the suitability of jatropha, its genetic composition, characteristics and soil requirements, or agronomy practices, marketability and other undisclosed information about the crop. In Ethiopia, 
Mozambique and Ghana, where land is the greatest asset for rural livelihoods, there was no critical consideration of land issues in terms of how best to incorporate jatropha investments without local land denial and subsequent land alienation. The research thus found that the time for jatropha investment was generally wrong, since it should have been a period of in-depth studies and knowledge sharing amongst countries before investments were gradual started. The period was thus 'research to prove before production' instead of the 'wait-and-see approach' (Gordon et al., 2003) after production, which was an easy way out and a short-cut to meet doubtful expectations.

The wait-and-see approach, according to Gordon et al. (2003), is a deferment option approach, which is adopted due to the uncertainties associated with the potential allocation of information breaches. This uncertainty is the result of the potential vulnerabilities and threats associated with breaches. Due to these uncertainties, it may be rational to take a wait-and-see approach.

In the case of Mexico, it was obvious that the local systems of jatropha production needed improvement through training and capacity building before the actual jatropha investment, but this never took place. In the Indian case, the government was not financially prepared for jatropha investments and vague promises were made but not fulfilled; as such, noone expected positive outcomes from the jatropha investment in the country. The Chinese case also saw limited support offered by the government to corporate jatropha investors, which led them to pull out from the investments. If the government had positioned itself to substantially support corporate bodies through subsidies during the investment, the development outcomes might have been positive. In Ethiopia, Mozambique and Ghana, foreign investors rushed to invest without recognizing the traditional land rights of the local people. Without this social license from the traditional landowners and users, instituting a successful business will always be difficult to achieve. Figure 2.2 presents a summary of the global transformation creation trajectory through jatropha investment and its diversity, based on the approach to investment. 


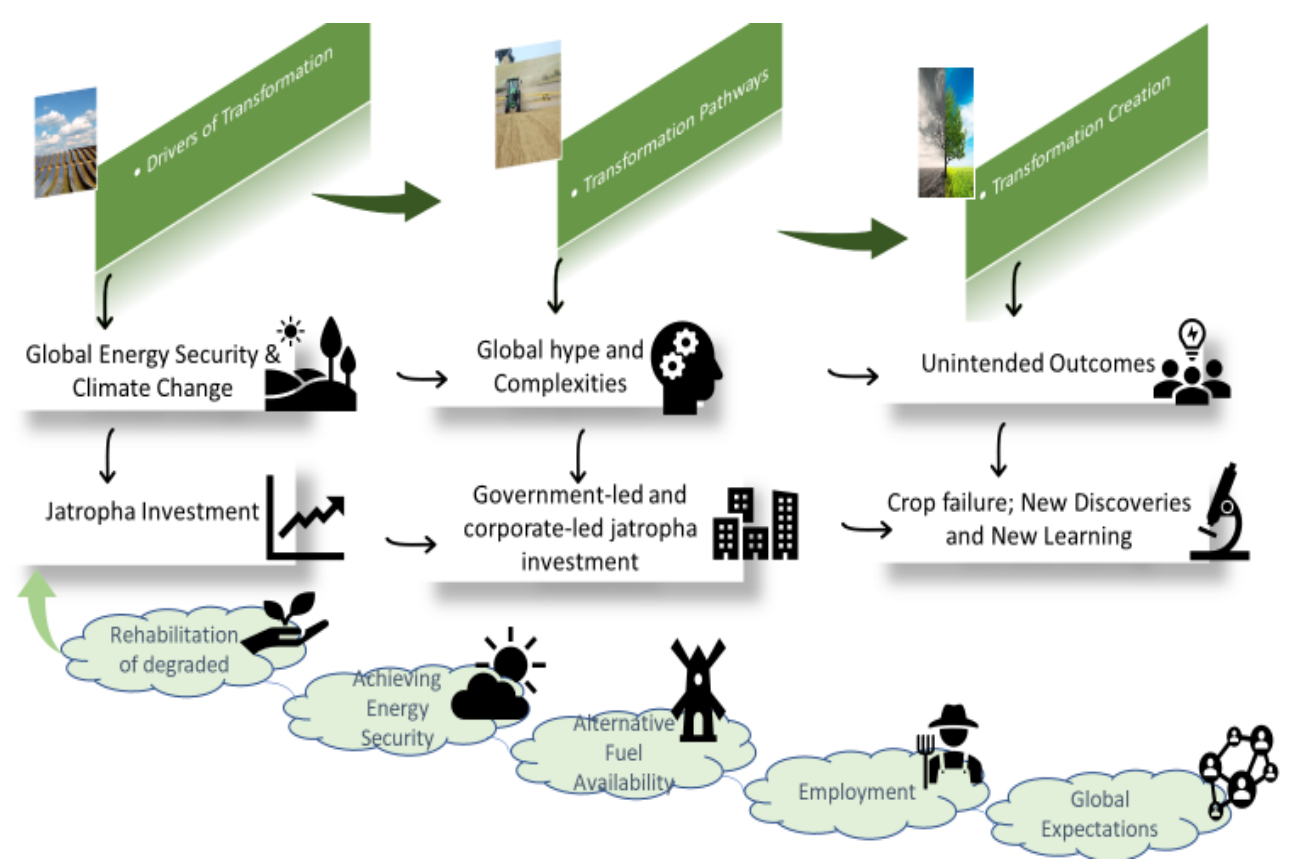

Figure 2.2. Global transformations trajectories of jatropha investments.

\subsection{Transformations in government- versus corporate-led jatropha investment}

Jatropha production has taken two main forms, that is, production initiated by the government and production initiated by corporate or private investors. In all six countries considered in the research, there was a jatropha boom and bust, whether led by the government or by corporate investors. In Mexico and India, jatropha investment was a national priority with the government direct involving itself in the cultivation process. The Chinese embraced a mix of socialist and capitalist approaches, but the government was somewhat reluctant to inject subsidies into the jatropha initiative. Though Ethiopia and Mozambique have centralized government control systems, the corporate agenda (capitalist approach) was embraced. In Ghana, it was corporateled in a decentralized democratic system.

Based on the corporate production approach adopted by these countries, there have been diversities in terms of the environmental, economic and social transformations after the collapse of jatropha. From the narrative, government involvement (socialist approach) tried to put people at the centre of the investment, whilst corporate investors (capitalist approach) placed the emphasis on profit. In relation to the differences in priorities, government-led production focused on marginal lands, instead of productive lands occupied by indigenous and tenant farmers (Axlesson \& Franzen, 2010; FDRE, 2011; Li et al., 2014; Ahmed et al., 2014; Montero 
et al., 2015). Thus, the rate of environmental destruction caused by government-led production has been lower than that caused by corporate investors. In fact, governments tried to put environmental integrity at the core of their investments. In India, for instance, Zafar (2011) showed that the government involvement in jatropha production was aimed at reducing soil erosion and rehabilitating land for the benefit of communities. In Mexico, the use of marginal lands by the government also meant that jatropha cultivation would not consume communities' green vegetation (Schut et al., 2010). In Yucatan State, Mexico, the government tied jatropha production to afforestation/reforestation, with 2350 ha used specifically to expand forests. Chinese government engagement in the investment also led to the extensive use of marginal lands, thus safeguarding productive land for the production of food crops.

In relation to corporate investors, the top priority of profit meant that land as host communities' main livelihood asset was taken away from them, and forests were transformed into large-scale jatropha plantations, as in the case in Ethiopia, Mozambique and Ghana. Flexibility in the use of abandoned land by both the government and corporate investors has varied sharply. In most of the government-led projects, local farmers were advised to use their land for jatropha production. After the poor outcomes of the initial investment, farmers transformed their land back into food crop production with ease. The marginal lands designated by the government for jatropha have lain idle, probably due to the fear of low fertility to support farming or the complexities associated with using government land for personal projects (Lambin, 2001).

In Mexico, India and China, for instance, where there was some active form of government participation, land used for the investment still lies dormant. As for the corporate investors, once they were unable to realize gains from their investments, they left their land dormant, and some community members have started using it for their own farming. In Ethiopia, Mozambique and Ghana, where investments were predominantly led by private investors, some farmers have returned to the jatropha land for farming purposes (Namburete, 2006; Cuvilas et al., 2010; Von Maltitz, 2016). The subsequent re-transformation of land back into farmland has helped to advance the livelihood of such farmers, though they can be alienated at any point in time, especially when another investment arrives. There have also been instances of corporate lands being re-leased to other private investors for investment; hence, farmers still face alienation despite the bust of jatropha projects in their communities.

The social implications associated with government- versus private-led investment vary. Whilst land resource conflict has become the hallmark of private investment due to alienation and unfair compensation, government-led investment has intensified social capital, 
helping to concretize social cohesion. In Ethiopia, Mozambique and Ghana, where investment was intensified by private actors, land rights issues became critical, leading to investor-farmer conflicts in the host communities (Mataveia, 2009; FDRE, 2011; Acheampong \& Campion, 2014). These conflicts affected social relations and somewhat interrupted the operational peace investors needed for sound investment. In the case of government-led investments, governmentowned lands were used; hence, issues of eviction did not arise (Valero, 2011). Again, farmers were encouraged to use their own land for jatropha cultivation. This solidified the unity of work, as farmers had to coordinate efforts and share responsibilities for the cultivation of a common crop, jatropha. As a result, government-led investment did not create social disturbances vis-àvis private investments.

In countries where the government led jatropha projects, particularly in India, the government's intention was to encourage local farmers through incentive-driven approaches, even though they were not successful. However, the government played the leading role, allowing farmers and agribusiness groups to use their own resources for investment. Jatropha was planted on large, medium and small scales, depending on the financial viability of the entities and individuals involved. Ethiopia, Mozambique, Ghana and China, to a certain extent saw the direct participation of corporate bodies in jatropha investment. These corporate bodies were both local and foreign entities. Most foreign investors (corporate bodies) invested in these countries due to the government's 'open-door policy'.

Unlike in Mexico and India, jatropha in Ethiopia, Mozambique and Ghana was cultivated on a large scale, with investors acquiring large tracts of land for their investments. Although there was land use change, issues regarding land takeovers and the recognition of local land rights were rare in Mexico, India and China due to the widespread use of marginal land (especially in Mexico and China) and the farmers' decision to use their own land for jatropha (India). In contrast, issues of land use rights and tenure security became a critical development issue in Ethiopia, Mozambique and China, as many local farmers were evicted from their land without their approval or commensurate compensation. This affected local agriculture, which had direct negative implications for food security. Concerns about food insecurity were also common in Mexico and India, where new pests and diseases were introduced, thus affecting food crops. Particularly in Mexico, the case was further worsened by some of the farmers deciding to abandon crop production for jatropha cultivation. China was unusual in that it did not suffer negative impacts on food production, as jatropha was predominantly cultivated on marginal land. 


\subsection{Bust of investment}

Jatropha investment led to the creation of temporary jobs for the local actors involved, but this did not really enhance their livelihoods. In all six cases, jatropha was unprofitable, and thus the target of meeting global energy needs through biofuel was dashed. This led to the jatropha bust. Actors including governments, local agribusiness groups, farmers and foreign investors have largely withdrawn their investments due to the unprofitability of jatropha. In Mexico, India, Ethiopia, Ghana and Mozambique, some parts of jatropha land are used for the cultivation of other crops either by farmers or other investors, whilst other parts are yet to be used. Since marginal land was used for jatropha in China, the land is still idle after the cessation of investment. Generally, jatropha failed because investments were made without commensurate empirical studies, especially at country-specific levels to prove or disprove the bold claims about the crop. Jatropha was just an ordinary crop, rather than a 'wonder' or 'miracle' crop.

The foregoing discussions imply that interventions based on lessons from both government-led and private-initiated investments need to critically address the outcomes associated with large-scale investment projects. This needs critical scrutiny and policy-based initiatives to comprehensively address the problems associated with large-scale investments initiated by either governments or private individuals.

These countries have now come to terms with the uncertain path of jatropha transformation. Transformation patterns have ultimately followed policy, investment and land use transformations (see Table 2.1). Thus, biofuel policy attention has shifted from jatropha to other feedstocks, investments in jatropha are now made in other crops or are not made at all, and land once used for jatropha is now used for farming by either smallholders or other investors or has been abandoned. Jatropha transformation creation has led to socioeconomic and environmental outcomes, with their diversities widely dependent on the perspective from which such investments were implemented, namely either by the government (Mexico and India) or corporate investors (Ethiopia, Mozambique and Ghana), or by both (China). As inferred from Deming (1993), and Dazko and Sheinberg's (2005) theory of transformation creation, the socioeconomic and environmental outcomes of jatropha transformation in these six countries have led to new discoveries and learning, especially towards an effective response to inform future investments. These countries have therefore come to terms with the outcomes of investment transformation system change through the path of transformation, so vast potential lessons exist for them to tap into to drive future agro-investment in a positive direction. Table 2.1 presents a summary of the reviewed literature on transformation creation through global 
jatropha investment of the six selected former jatropha producing countries, and their patterns of transformation vis-à-vis policy, investment and land use.

Table 2.1. Global perspectives of transformation creation in different jatropha centres.

\begin{tabular}{llllll}
\hline \multirow{2}{*}{ Support } & \multicolumn{4}{c}{ Transformation } \\
\cline { 3 - 6 } sources: & Policy & Environmental, & Investment & Land use \\
Government- & transforma & social and & transforma & transforma \\
versus & tion & economic & tion & tion \\
& corporate-led & & transforma & & \\
jatropha & & tion & & \\
investment & & & &
\end{tabular}

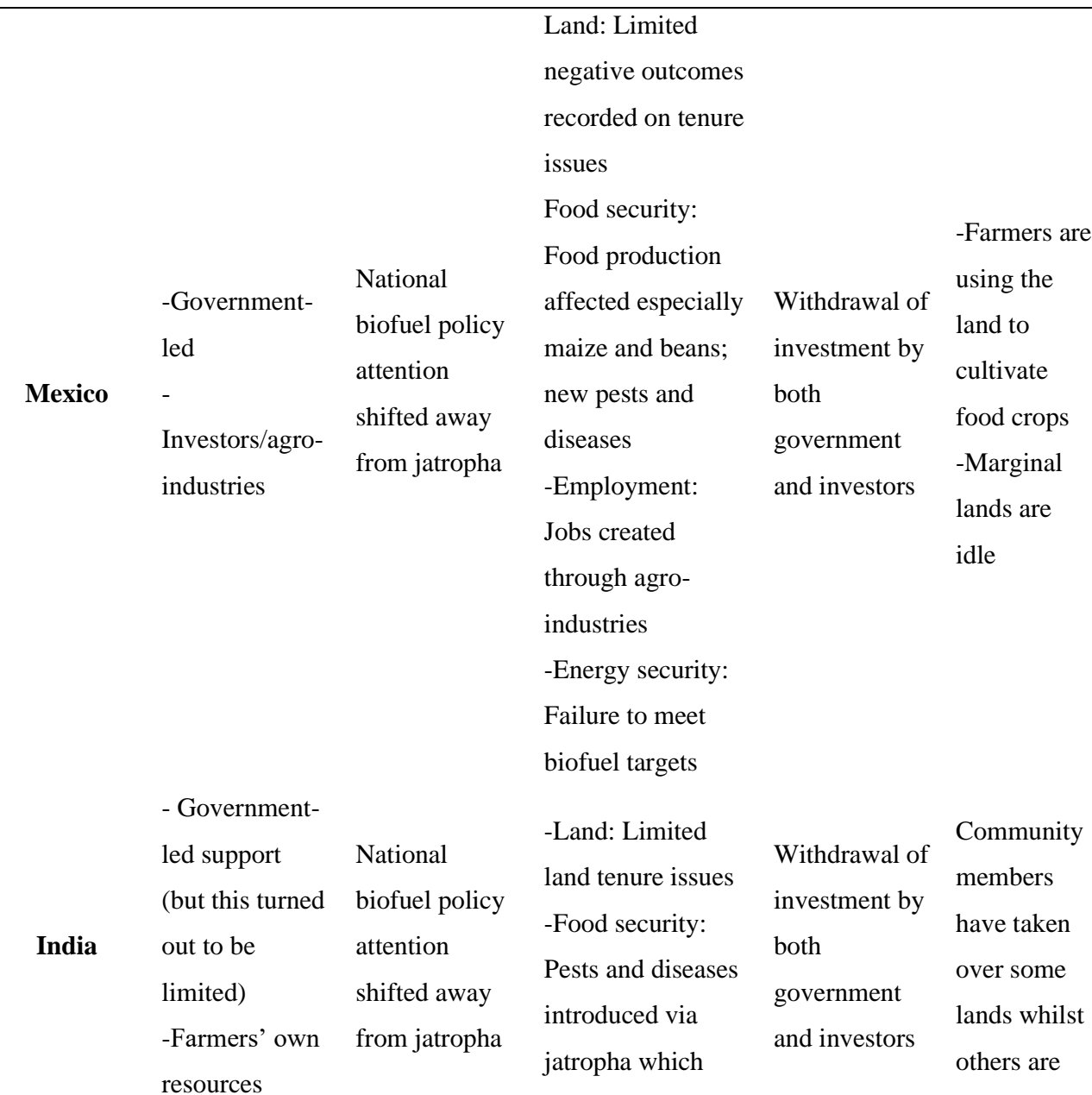


-Finance from

local

enterprises

- Corporate-led National

- Investors in

biofuel policy

collaboration

with the

government attention

shifted away

from jatropha affected food crop

production

-Employment:

Jobs created via

jatropha

production at the

local level

-Energy security:

Failure to meet

biofuel targets

-Land: -Land:

Limited land

tenure issues

Food security:

Food production

and availability

were not affected

by Jatropha

Employment: Jobs

were created

through contract

farming

-Energy security:

Failure to meet

biofuel targets

-Land: Issues on

land use rights and

National

- Corporate-led

biofuel policy

attention

-Government

Ethiopia support foreign

direct

investment

(FDI)

from jatropha

\section{shifted away}

towards

resilient policy

on agriculture

modernization tenure security

became a critical

development

concern

-Food security:

Jatropha somehow

affected food

production as

grazing areas and yet to be

utilized

Investment

withdrawn by

investors and -Lands lie

government's abandoned

interest has

dwindled

\section{-Investment}

halted in some

areas

-Investment

shifted to

other crops in

other areas
-Lands used

for other

crops by

investors

-Farmers

have taken

over their

land 
farmlands used for

rotational farming

were alienated

-Employment:

Contract jobs were

created, but

payments were

neither fair nor

competitive

-Energy security:

Failure to meet

biofuel targets

-Land: Issues on

land rights and

tenure security

became critical

development

concern -Investment

-Food security: diverted to -Land used

Mix results Pests other crops by for other

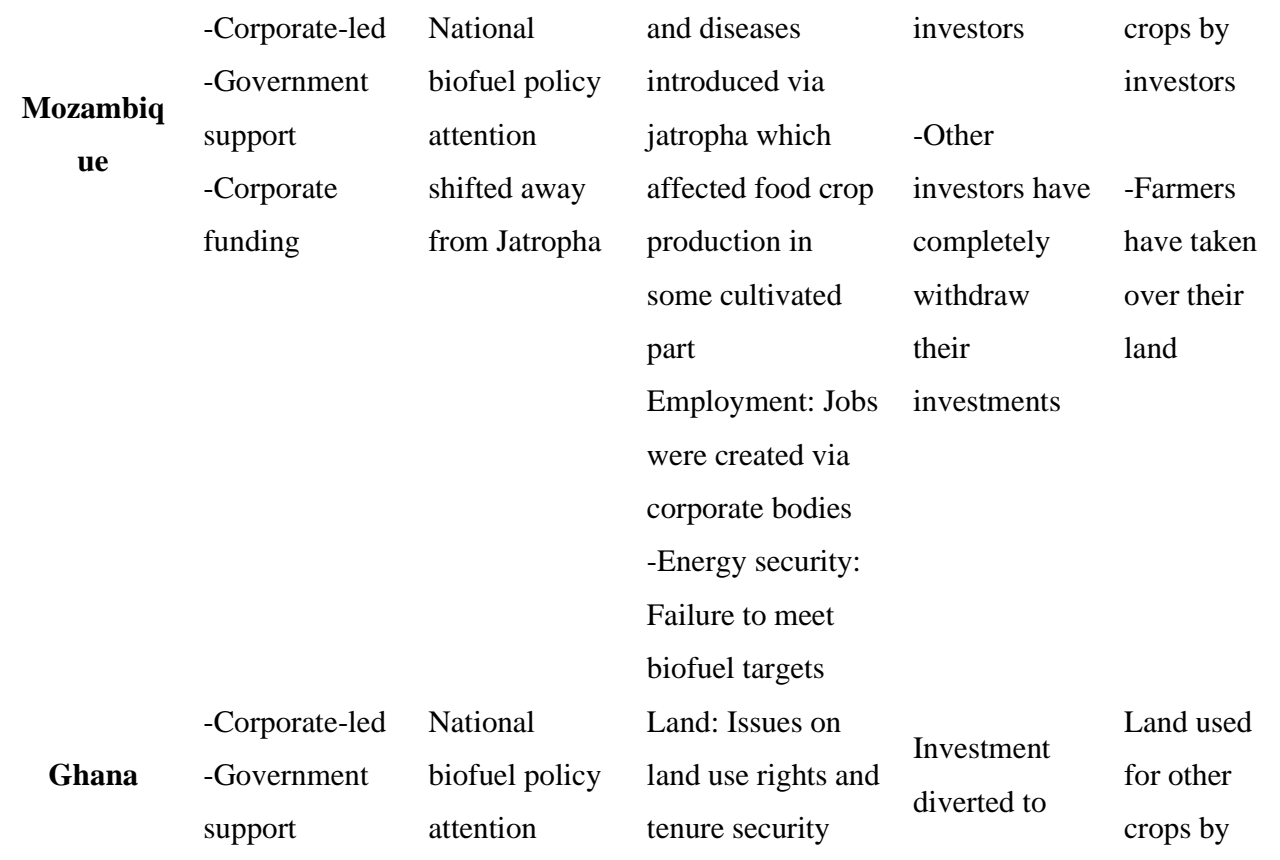




\begin{tabular}{|c|c|c|c|c|}
\hline $\begin{array}{l}\text {-Foreign direct } \\
\text { investment } \\
\text { (FDI) }\end{array}$ & $\begin{array}{l}\text { shifted away } \\
\text { from jatropha } \\
\text { towards }\end{array}$ & $\begin{array}{l}\text { became a critical } \\
\text { development } \\
\text { concern }\end{array}$ & $\begin{array}{l}\text { other crops by } \\
\text { investors }\end{array}$ & $\begin{array}{l}\text { Jatropha } \\
\text { investors/ne } \\
\text { w investors }\end{array}$ \\
\hline $\begin{array}{l}\text {-NGOs' } \\
\text { support }\end{array}$ & $\begin{array}{l}\text { resilient policy } \\
\text { on agriculture } \\
\text { modernization }\end{array}$ & $\begin{array}{l}\text {-Food security: } \\
\text { Jatropha somehow } \\
\text { affected food } \\
\text { production as } \\
\text { grazing areas and } \\
\text { farmlands used for } \\
\text { rotational farming } \\
\text { were alienated } \\
\text {-Employment: } \\
\text { Contract jobs were } \\
\text { created, but } \\
\text { payments were } \\
\text { neither fair nor } \\
\text { competitive } \\
\text {-Energy security: } \\
\text { Failure to meet } \\
\text { biofuel targets }\end{array}$ & $\begin{array}{l}\text {-Other } \\
\text { investors have } \\
\text { completely } \\
\text { withdrawn } \\
\text { their } \\
\text { investments }\end{array}$ & $\begin{array}{l}\text {-Farmers } \\
\text { have taken } \\
\text { over their } \\
\text { land but with } \\
\text { no tenure } \\
\text { security on } \\
\text { land }\end{array}$ \\
\hline
\end{tabular}

\section{Conclusions}

The global recognition of jatropha as a 'wonder' crop has clearly faded. The major investment destinations reviewed in this study failed to achieve the expected results in terms of alleviating local and global energy poverty, reducing greenhouse gas (GHG) emissions, and enhancing local livelihoods and development. The review established that the reason for establishing global jatropha investment - namely to serve as an alternative source of fuel - failed because of the unexpected complexities of the uncertainties and the ubiquitous nature of the hype, which focused on the deferment option or the 'wait-and-see' approach to global jatropha investment. These frustrations have caused governments and investors to lose interest in jatropha. It was over-hyped and lacked extensive and convincing scientific research. Jatropha will no longer attract popular attention, as countries seem reluctant to invest in it.

The current phase of jatropha transformation in the studied countries calls for them to move on, as they need to appreciate diversity in policy interventions in relation to key factors 
that lead to the investment implementation processes. This is premised on the fact that the outcomes of the jatropha transformations in these countries are opposite to what was expected. Differences in socioeconomic and environmental outcomes call for these countries to reflect upon the existing potentials and constraints created for responsive policy measures towards their biofuel sectors. These countries have now switched their biofuel policy attention from jatropha to other feedstocks, and it is expected that these transformed policies will take precautions based on lessons learnt from the jatropha investments as well as the current situations that have been presented as an outcome through their respective travels on the path of transformation (Deming, 1993; Daszko \& Sheinberg, 2005).

We support the shift in policy attention, since we are not optimistic about the economic and production viability of jatropha (even if treated with adequate responsibility). Perhaps considerable attention paid to other feedstocks, as these countries have adopted, might have a future as a better alternative source of energy. It is expected that countries that embrace similar investment approaches - for instance, Mexico and India for government-led investment and Ethiopia, Mozambique and Ghana for corporate-led investment - might have some interrelated responses. Policy measures should, however, clearly reflect the peculiar dynamics in each country for effective outcomes.

Our research shows that the adoption and promotion of any new crop must be based on incremental measures for sound policy responsiveness and implementation. A rapid switch to any new crop just because it has been widely propagated by the international community as a response to a particular development need is not justified. Thought-provoking policy measures are needed, premised on broad consultations and a participatory paradigm characterized by indepth empirical research within a particular country. As suggested by Muys et al. (2014), policy measures towards the adoption and promotion of new crops should hinge on viable data from proposed investment communities as well as a cost-benefit analysis of the outcomes of such investments. Even if this proves satisfactory, initial investment based on experimental trials in selected locations should be the first step, as this can help to reveal peculiar uncertainties and problems associated with such crops, as suggested by Soto et al. (1991).

Another policy implication of these findings is centred on policy interconnectedness, and the need for countries to be aware and appreciate such connections for effective measures. Lempert (2003) showed that a single policy implementation is usually insufficient to tackle a particular development problem. Therefore, there is a need for national governments, corporate investors and other major stakeholders to understand that the policy environment is a system made up of a network of several policies that work interrelatedly to address a particular 
development need (Kenis \& Schneider, 1991). This policy system is also applicable to the emergence and promotion of a new crop that is likely to present solutions to a development problem. Ultimately, government and private investors must reflect on the suitability of endorsing new investment initiatives before appraising the investment viability. Even if there is such an endorsement, the aftermath of the failures of such initiatives should be appraised to understand the impacts of the failure to transform the system.

The above discussions have provided insights into jatropha investment from the global perspective, demonstrating the interconnectivity of national issues. Here, we see that the jatropha spaces have produced an array of new issues. This is why the subsequent empirical cases will build on this review and policy discussion to understand these new issues emerging from the trajectory of jatropha investment and the aftermath of jatropha failure in Ghana. Ghana as a case is interesting, because it is a former epicentre of jatropha investment and the trajectory of jatropha from its boom to its bust and aftermath is highly visible, as are new investments in former jatropha spaces. Ghana also has complex socio-political systems that have a strong influence on land tenure arrangements. Hence, the next three chapters will show the trajectories of these complexities.

\section{References}

Acheampong, E. \& Campion, B.B. (2014). The Effects of Biofuel Feedstock Production on Farmers' Livelihoods in Ghana: The Case of Jatropha curcas. Sustainability 2014, 6, $4587-4607$.

Achten, W. M., Mathijs, E., Verchot, L., Singh, V. P., Aerts, R., \& Muys, B. (2007). Jatropha biodiesel fueling sustainability? Biofuels, Bioproducts and Biorefining: Innovation for a sustainable economy, 1(4), 283-291.

Achten, W. M., Verchot, L., Franken, Y. J., Mathijs, E., Singh, V. P., Aerts, R., \& Muys, B. (2008). Jatropha bio-diesel production and use. Biomass and bioenergy, 32(12), 10631084.

Achten, W., Maes, W., Aerts, R., Verchot, L., Trabucco, A., Mathijs, E., \& Muys, B. (2010). Jatropha: from global hype to local opportunity. Journal of Arid Environments, 74(1), 164-165.

Action Aid. (2009). Rethinking the Rush to Agrofuels: Lessons from Ghana, Senegal and Mozambique on the Unintended Consequences of Agrofuels Production for Food Security; Action Aid: Johannesburg, South Africa. 
Agyekumhene, J.K. (2006). Supporting the development of Jatropha farms with Microfinance for job and wealth creation, reduction in urban drift. In Proceedings of the UNCTAD Biofuels Workshop, Financing Biofuels with Special Emphasis on Jatropha and CDM, Accra, Ghana, 13-14 November 2006.

Aha, B., \& Ayitey, J. Z. (2017). Biofuels and the hazards of land grabbing: Tenure (in) security and indigenous farmers' investment decisions in Ghana. Land Use Policy, 60, 48-59.

Ahmed, A.; Kanton, S.; Godwin, K.; Rahim, A.A., \& Salia, R.A. (2014). Biofuel development and large-scale land acquisition in Ghana, implications for land use planning. International Journal of Development Research, 4, 2563-2571.

Amoah, O. (2006). Jatropha: A Catalyst for Economic Growth in Africa; An Official

UNCTAD Document; Anuanom Industrial Bio Products Limited: Accra, Ghana, 2006. Available online:

https://unctad.org/Sections/wcmu/docs/ditc_comb_Jatropha001_en.pdf (accessed on 25 December 2018).

Ariza-Montobbio, P., \& Lele, S. (2010) Jatropha plantations for biodiesel in Tamil Nadu, India: Viability, livelihood trade-offs, and latent conflict. Ecological Economics, 70, 189-195.

Axlesson, L., \& Franzen, M. (2010). Performance of Jatropha Biodiesel Production and Its Environmental and Socio-Economic Impacts-A Case of Southern India. Master's Thesis, Department of Energy and Environment, Chalmers University of Technology, Goteborg, Sweden.

Banerjee, A.; Halvorsen, K.E.; Eastmond-Spencer, A., \& Sweitz, S.R. (2017). Sustainable development for whom and how? Exploring the gaps between popular discourses and ground reality using the Mexican Jatropha biodiesel case. Environmental Management, 59, 912-923.

Benge, M. (2006). Assessment of the Potential of Jatropha Curcas, (Biodiesel Tree,) for Energy Production and Other Uses in Developing Countries; Agroforestry Office, USAID: Laguna, Philippians. Available online:

http://www.ascension-publishing.com/BIZ/jatropha.pdf (accessed on 1 January 2019).

Bassey, N. (2008). The Agrofuels Debate in Africa: Challenges and Opportunities. In Proceedings of the Ecological Agriculture: Mitigating Climate Change, Providing Food Security and Self-Reliance for Rural Livelihoods in Africa Conference, Addis Ababa, Ethiopia, 26-28 November 2008.

Bassey, N. (2009). Agrofuels: The corporate plunder of Africa. Third World Network, 223, 2126. 
Batidzirai, B.; Faaij, A.P.C., \& Smeets, E. (2006). Biomass and bioenergy supply from Mozambique. Energy for Sustainable Development, 10, 54-81.

Birega, G. (2008). Agrofuels beyond the hype lessons and experiences from other countries. Agrofuel development in Ethiopia: Rhetoric, reality and recommendations, 67-83.

Boamah, F. (2014). How and why chiefs formalize land use in recent times: The politics of land dispossession through biofuel investments in Ghana. Review of African Political Economy, 41, 406-423.

Boni, S. (2006). Indigenous Blood and Foreign Labor: The Ancestralization of Land Rights in Sefwi (Ghana). In Land and the Politics of Belonging in West Africa; Kuba, R., Lentz, C., eds; E.J. Brill: Leiden, The Netherlands, pp. 161-186

Bos, H.L.; Slingerland, M.A.; Elbersen, W., \& Rabbings, R. (2008). Beyond Agrification; twenty years of policy and innovation for non-food application of renewable resources in the Netherlands. Biofuels, Bioproducts and Biorefining, 2, 343-357.

Bosch, C.; Zeller, M. The impacts of wage employment of jatropha plantation on income and food security of rural households in Madagascar-A panel data analysis. Quarterly Journal of International Agriculture, 52, 119-140.

Bossio, D.; Erkossa, T.; Dile, Y.; McCartney, M.; Killiches, F., \& Hoff, H. (2012). Water Implications of Foreign Direct Investment in Ethiopia's Agricultural Sector. Water Alternatives, 5, 223-242.

Brenner, R. (1982). The agrarian roots of European capitalism. Past Present, 97, 16-113.

Brew Hammond, A. (2009). Bioenergy for accelerated agro-industrial development in Ghana. In Proceedings of the Bioenergy Markets, West Africa Conference, Accra, Ghana, 27 October 2009.

Brittaine, R., \& Lutaladio, N. (2010). Jatropha: A Smallholder Bioenergy Crop: The Potential for Pro-Poor Development; Food and Agriculture Organization of the United Nations (FAO): Reading, UK, Volume 8.

Chan, C.J. (2010). En proceso el cultivo de 62,000 hectáreas de jatropha enYucatán. Diario. (In Spanish). Available online: http://biodiesel.com.ar/3289/cultivo-de-jatropha-paraproducir-biodiesel-en-mexico (accessed on 28 August 2018).

Cotula, L., Dyer, N., \& Vermeulen, S. (2008). Fueling Exclusion? The Biofuels Boom and Poor People's Access to Land. IIED.

Cuvilas, C.A.; Jirjisa, R., \& Lucas, C. (2010). Energy situation in Mozambique: A review. Renewable \& Sustainable Energy Reviews, 14, 2139-2146. 
Dias, L. D. S., Missio, R. F., \& Dias, D. C. F. S. (2012). Antiquity, botany, origin and domestication of Jatropha curcas (Euphorbiaceae), a plant species with potential for biodiesel production. Genetics and Molecular Research, 11(3), 2719-2728.

Deming, W. E. (1993). The New Economics; MIT Press: Cambridge, UK, 1993.

Daszko, M., \& Sheinberg, S. (2003) Survival is optional: Only leaders with new knowledge can lead the transformation. Transformation, 408, 247-7757.

Downe-Wamboldt, B. (1992). Content analysis: Method, applications, and issues. Health Care Women InternationL, 13, 313-321.

Energy Commission. (2006). Strategic National Energy Plan 2006-2020; Energy Commission: Accra, Ghana.

Energy Commission. (2010). Draft Bioenergy Policy of Ghana; Energy Commission: Accra, Ghana.

Ethiopian Biofuels Development Directorate (EBDD). (2011). Assessment of Biofuels Projects Status in Ethiopia; Melca Mahiber: Addis Ababa, Ethiopia, 2011. Available online: http://melcaethiopia.org/wpcontent/uploads/2011/05/Eth_Biofuel_AssessmentFinal.pdf (accessed on 2 March 2019).

Farazmand, A. (2003). Chaos and transformation theories: A theoretical analysis with implications for organization theory and public management. Public Organization Review, 3, 339-372.

Federal Democratic Republic of Ethiopia (FDRE). (2011). Ethiopia's Climate-Resilient Green Economy. Green Economy Strategy; Environmental Protection Authority: Addis Ababa, Ethiopia; Available online: https://theredddesk.org/resources/ethiopias-climateresilient-green-economy-green-economy-strategy (accessed on 10 June 2019).

Food and Agriculture Organization (FAO). (2012). The State of Food and Agriculture. Investing in Agriculture for a Better Future; International Institute of Environmental Development (IIED): London, UK.

Food and Agriculture Organization (FAO). (2013). The Gender and Equity Implications of Land-Related Investments on Land Access, Labour and Income-Generating Opportunities in Northern Ghana: The Case Study of Integrated Tamale Fruit Company; FAO: Rome, Italy.

Ghana Energy Commission. (2005). Ghana Bio-fuels Policy. Policy Recommendations. Final Draft. Accra: Ghana Energy Commission.

Gleick, J. Chaos. (1987). Making a New Science; Knopf: New York, NY, USA. 
Global Agricultural Information Network (GAIN). (2012). Biofuel Annuals: Uncertainty of the Future of Mexican Biofuels. Gain Report Number MX2507; GAIN: Washington, DC, USA.

Gordon, L.A.; Loeb, M.P., \& Lucyshyn, W. (2003). Information security expenditures and real options: A wait-and-see approach. Computer Security Journal, 19, 1-7.

Graham, V.M.; Gasparatos, A.; Fabricius, C. The Rise, Fall and Potential Resilience Benefits of jatropha in Southern Africa. Sustainability, 6, 3615-3643.

Hamenoo, S.V.Q. (2014) The Effects of Large-Scale Land Acquisition for Jatropha Plantation on Small-Scale Farmers in Rural Communities in the Asante Akim North District. Master's Thesis, School of Graduate Studies Kwame Nkrumah University of Science and Technology, Kumasi, Ghana. Available online: http://dspace.knust.edu.gh/bitstream/123456789/7157/1/HAMENOO\%2C\%20SIMON \%20VICTORY\%20QUARCSON.pdf (accessed on 10 July 2018).

Henning, R. K. (2003). The jatropha booklet: A guide to jatropha promotion in Africa. Bagani GbR: Weissensberg, Germany, 5-33.

Hill, J., Nelson, E., Tilman, D., Polasky, S., \& Tiffany, D. (2006). Environmental, economic, and energetic costs and benefits of biodiesel and ethanol biofuels. Proceedings of the National Academy of Sciences, 103(30), 11206-11210.

Hinojosa, F.I.D., \& Skutsch, M. (2011). Impact of establishing jatropha curcas t produce biodiesel in three communities of Michocan, Mexico, approached from different scales. Revista geográfica de América Central, 2, 1-15.

Hughes, A.K.; Knox, A., \& Jones-Casey, K. (2011). Focus on Land Brief in Africa: Pressure on Land from Large Scale Biofuel Production. Lesson 2; Funded by the Bill and Melinda Gates foundation. IFAD Occasional Paper 2; World Resources Institute in Partnership with Landesa Rural Development Institute: Washington, DC, USA.

Iddrisu, I., \& Bhattacharyya, S.C. (2015). Ghana's bioenergy policy: Is $20 \%$ biofuel integration achievable by 2030? Renew. Sustainable Energy Reviews, 43, 32-39.

IICA. (2010). México-Inicia Yucatán Cuzltivo de Jatropha para Biodiesel; IICA: New Delhi, India.

International Land Coalition. (2011). Global Assembly 2011; ILC: Tirana, Albania.

James, L. (2010). Theory and Identification of Marginal Land and Factors Determining Land Use Change. Master's Thesis, Department of Agricultural, Food, and Resource Economics, Michigan State University, East Lansing, MI, USA. 
Jingura, R. M., Matengaifa, R., Musademba, D., \& Musiyiwa, K. (2011). Characterisation of land types and agro-ecological conditions for production of Jatropha as a feedstock for biofuels in Zimbabwe. Biomass and Bioenergy, 35(5), 2080-2086.

Lambin, E.F.; Turner, B.L.; Geist, H.J.; Agbola, S.B.; Angelsen, A.; Bruce, J., \& George, P. (2001). The causes of land use and land cover change: Moving beyond the myths. Global Environmental Change 11, 261-269.

Lempert, R.J. (2003). Shaping the Next One Hundred Years: New Methods for Quantitative, Long-Term Policy Analysis; Rand Corporation: Santa Monica, CA, USA.

Karlson, G., \& Banda, K. (2009). Biofuels for Sustainable Rural Development and Empowerment of Women: Case Studies for Africa and Asia; Energia: Leusden, The Netherlands.

Keijzer, N., \& Lundsgaarde, E. (2017). When Unintended Effects Become Intended: Implications of 'Mutual Benefit' Discourses for Development Studies and Evaluation Practices; Working Paper; Ministry of Foreign Affairs of the Netherlands: Hague, The Netherlands; Radboud University: Nijmegen, The Netherlands.

Kenis, P., \& Schneider, V. (1991). Policy networks and policy analysis: Scrutinizing a new analytical toolbox. In Policy Networks: Empirical Evidence and Theoretical Considerations; Campus Verlag: Frankfurt, Germany; pp. 25-59.

Kenney-Lazar, M. (2012). Plantation rubber, land grabbing and social-property transformation in southern Laos. Journal of Peasant Studies, 39, 1017-1037.

Koch, D.J., \& Schulpen, L. (2017). Unintended effects of international cooperation: A preliminary literature review. In Proceedings of the Unintended Effects of International Cooperation, Hague, The Netherlands, 16-17 January 2017.

Kondracki, N.L., \& Wellman, N.S. (2002). Content analysis: Review of methods and their applications in nutrition education. Journal of Nutrition Education and Behavior, 34, 224-230.

Leonti, M., Sticher, O., \& Heinrich, M. (2003). Antiquity of medicinal plant usage in two Macro-Mayan ethnic groups (Mexico). Journal of ethnopharmacology, 88(2-3), 119124.

Li, J.; Bluemling, B.; Mol, A.P.J., \& Herzfeld, T. (2014). Stagnating Jatropha Biofuel Development in Southwest China: An Institutional Approach. Sustainability, 6, 31923212 . 
Mataveia, M. (2009). Biofuel Policy and Strategy for Mozambique. Presented at a Conference on 'Bioenergy for Sustainable Development in Africa-Lessons learnt from COMPLETE'; Available online: http://www.globalbioenergy.org/fileadmin/user_upload/gbep/docs/2009_events/CSD_ side_event_NY/Mataveia_-_GBEP_CSD_side_event_140509.pdf (accessed on 10 June 2019).

Miles, M.B., \& Huberman, A.M. (1994). Qualitative Data Analysis: An Expanded Sourcebook; Sage: Thousand Oaks, CA, USA.

Ministry of Mines and Energy (MoME). (2007). Biofuel Development and Utilization Strategy; The Federal Democratic Republic of Ethiopia: Addis Ababa, Ethiopia.

Ministry of New and Renewable Energy (MNRE), Government of India (2008). National Policy on Biofuels. Available online: https://mnre.gov.in/filemanager/UserFiles/biofuel_policy.pdf (accessed on 5 January 2019).

Ministry of New and Renewable Energy (MNRE). (2017). Remap Renewable Energy

Prospects for India. Available online: https://www.irena.org//media/Files/IRENA/Agency/Publication/2017/May/IRENA_R Emap_India_paper_2017.pdf (accessed on 3 February 2019).

Montero, G.; Stoytcheva, M.; Coronado, M.; García, C.; Cerezo, J.; Toscano, L., \& León, J.A. (2015). An overview of biodiesel production in Mexico. In Biofuels-Status and Perspective; InTech: London, UK.

Morse, J.M., \& Field, P.A. (1995). Qualitative Research Methods for Health Professionals, 2nd ed.; Sage: Thousand Oaks, CA, USA.

Murphy, J., \& Hallinger, P. (1992). The principalship in an era of transformation. Journal of Educational Administration, 30(3).

Muys, B.; Norgrove, L.; Alamirew, T.; Birech, R.; Chirinian, E.; Delelegn, Y.; Ehrensperger, A.; Ellison, C.A.;

Feto, A., \& Freyer, B. (2014). Integrating mitigation and adaptation into development: The case of Jatropha curcas in sub-Saharan Africa. Global Change Biology Bioenergy, 6, 169171.

Namburete, S. (2006). Mozambique biofuels. In Proceedings of the African Green Revolution Conference, Oslo, Norway; Volume 31. Available online: http://mediabase.edbasa.com/kunder/yaraimages/agripres/agripres/j2006/m09/t04/000 0443_2.pdf (accessed on 3 March 2019). 
Nogueira, L.A.H. (2004) Perspectivas de un Programa de Biocombustibles en América Central; CEPAL/GTZ: Mexico City, Mexico, 2004. Available online: https://repositorio.cepal.org/bitstream/handle/11362/25669/LCmexL606_es.pdf?seque nce $=1 \&$ isAllowed $=y$ (accessed on 1 June 2019).

Openshaw, K. (2000). A review of Jatropha curcas: an oil plant of unfulfilled promise. Biomass and Bioenergy, 19(1), 1-15.

Patton, M.Q. (2002). Qualitative Research and Evaluation Methods; Sage: Thousand Oaks, CA, USA.

Portner, B.; Ehrensperger, A.; Nezir, Z.; Breu, T., \& Hurni, H. (2013). Biofuels for a Greener Economy? Insights from Jatropha Production in Northeastern Ethiopia. Sustainability, 6, 6188-6202.

Prueksakorn, K., \& Gheewala, S.H. (2006). Energy and Greenhouse Gas Implications of Biodiesel Production from Jatropha curcas. In Proceedings of the 2nd Joint International Conference on Sustainable Energy and Environment (SEE 2006), Bangkok, Thailand, 21-23 November 2006.

Rahmato, D. (2011). Land to Investors: Large-Scale Land Transfer in Ethiopia; FSS Policy Debate Series No.1; Forum of Social Studies (FSS): Addis Ababa, Ethiopia.

Reinhardt, G.; Gartner, S.; Rettenmaier, N.; Munch, J., \& Von Falkenstein, E. (2007). Screening Life Cycle Assessment of Jatropha Biodiesel; IFEU-Institute for Energy and Environmental Research Heidelberg Gmbh: Heidelberg, Germany.

Robinson, S., \& Beckerlegge, J. (2008). Jatropha in Africa: Economic Potential. 2008. Available online: http://www.wolfsberg.com/documents/Jatropha_in_Africa_Economic_Potential.pdf (accessed on 18 January 2019).

Rodriguez, O.A.V.; Vazquez, A.P., \& Gamboa, (2014). C.M. Drivers and Consequences of the First Jatropha Curcas Plantations in Mexico. Sustainability, 6, 3732-3746.

Romijn, H.A. (2011). Land clearing and Green House Gas emissions from jatropha biofuels on African Miambo Woodland. Energy Policy, 39, 5751-5762.

Romijn, H.; Heijnen, S.; Colthoff, J.R.; De Jong, B., \& Van Eijck, J. (2014). Economic and Social Sustainability Performance of Jatropha Projects: Results from Field Surveys in Mozambique, Tanzania and Mali. Sustainability, 6, 6203-6235.

Rucoba, G.A.; Munguía, G.A., \& Sarmiento, F.F. (2012). Between Jatropha and poverty: Reflections about biofuels production in temporary lands in Yucatan (Entre la Jatropha 
ylapobreza: Reflexiones sobre la producción de agrocombustibles en tierras de temporal en Yucatán). Revista geográfica de América Central, 21, 115-142.

Rulli, M.C., Savioria, A., \& D’Odorico, P. (2013). Global land and water grabbing. Proceedings of the National Academy of Sciences of the United States of America, 110, 892-898.

Sarasvathy, S. D., \& Dew, N. (2005). New market creation through transformation. Journal of evolutionary Economics, 15(5), 533-565.

Schoneveld, G., German, L., \& Nutakor, E. (2010). Towards sustainable biofuel development: Assessing the local impacts of large-scale foreign land acquisitions in Ghana. CIFOR. https://www.cifor.org/knowledge/publication/3597/

Schut, M.; Slingerland, M., \& Locke, A. (2010). Biofuel developments in Mozambique. Update and analysis of policy, potential and reality. Energy Policy, 38, 5151-5165.

Skutsch, M., de los Rios, E., Solis, S., Riegelhaupt, E., Hinojosa, D., Gerfert, S., \& Masera, O. (2011). Jatropha in Mexico: environmental and social impacts of an incipient biofuel program. Ecology and Society, 16(4).

Slingerland, M., \& Schat, M. (2014). Jatropha Developments in Mozambique: Analysis of structural conditions influencing Niche-Regime Interactions. Sustainability, 6, 75417563.

Solomon, B.D., \& Bailis, R. (2013). Sustainable Development of Biofuels in Latin America and the Caribbean; Springer Science \& Business Media, 2013; Available online: https://link.springer.com/book/10.1007\%2F978-1-4614-9275-7 (accessed on 10 June 2019).

Soto, I.; Ellison, C.; Kenis, M.; Diaz, B.; Muys, B., \& Mathijs, E. (2018). Why do farmers abandon jatropha cultivation? The case of Chiapas, Mexico. Energy for Sustainable Development, 42, 77-86.

Sulle, E., \& Nelson, F. (2009). Biofuels, land access and rural livelihoods in Tanzania. IIED.

Sweitz, S. (2018). Sustainability, Biofuels, and the Future in Yucatán. In The Quest for Jatropha Biodiesel and Sustainability in Yucatan; Ediciones de la Universidad Autónoma de Yucatán: Mexico City, Mexico, p. 239.

Technoserve. (2007). Feasibility Study of Biofuel Production in Ghana: Assessing Competitiveness and Structure of the Industry's Value Chain; Final Report; Technoserve: Washington, WA, USA. Available online: http://s3.amazonaws.com/zanran_storage/elliott.gwu.edu/ContentPages/2454285956.p df (accessed on 18 August 2018). 
Timko, J. A. (2014). An analytical framework for assessing the impacts of jatropha curcas on local livelihoods. Conflicts over natural resources in the global south conceptual approaches, 174-191.

Timko, J., Amsalu, A., Acheampong, E., \& Teferi, M. (2014). Local perceptions about the effects of Jatropha (Jatropha curcas) and Castor (Ricinus communis) plantations on households in Ghana and Ethiopia. Sustainability, 6(10), 7224-7241.

Tsegaye, W., \& Glantz, M.H. (2011) Biofuels in Africa: A Pathway to Development; Occasional Paper No. 43; International Research Center for Energy and Economic Development: Boulder, CO, USA.

UNDESA. (2007). Small-Scale Production and Use of Liquid Biofuels in Sub-Saharan Africa: Perspective for Sustainable Development; UNDESA: New York, NY, USA.

UN Energy. (2007). Sustainable Bioenergy: A Framework for Decision Makers; Henceforth UN-Energy: New York, NY, USA. Available online: http://www.fao.org/3/a1094e/a1094e00.pdf (accessed on 4 February 2019).

Von Maltitz, G.P.; Gasparatos, A.; Fabricius, C.; Morris, A., \& Willis, K.J. (2016). Jatropha cultivation in Malawi and Mozambique: Impact on ecosystem services, local human well-being and poverty alleviation. Ecology and Society, 21, 3.

Valero, P.J.; Cortina, V.S., \& Vela, V.S. (2011). The project of biofuels in Chiapas: Experiences of physic nut (Jatropha curcas) farmers within the rural crisis framework. Estud. Soc., $19,120-144$.

Van Eijck, J.; Rom, C.J.; Romijn, H.; Heijnen, S.; De Ruijter, F., \& Jongschaap, R. (2013). Jatropha Sustainability Assessment, Data from Tanzania, Mali and Mozambique; NL Agency: Utrecht, The Netherlands.

Wendimu, M.A. (2016). Jatropha potential on marginal land in Ethiopia: Reality or myth? Energy for Sustainable Development, 30, 14-20.

Weyerhaeuser, H.; Tennigkeit, T.; Yufang, S., \& Kahrl, F. (2007). Biofuels in China: An Analysis of the Opportunities and Challenges of Jatropha Curcas in South West China, ICRAF Working Paper Number 53; ICRAF: Beijing, China.

Wheatley, M. (1999). Leadership and the New Science: Discovering Order in a Chaotic World, 2nd ed.; Berrett-Koehler: Washington, WA, USA.

Zafar, S. (2011). Biodiesel Scenario in India. Available online: https://www.academia.edu/30151096/Biodiesel_Scenario_in_India (accessed on 22 October 2018). 
Zamarripa-Colmenero, A., \& Diaz Padilla, G. (2008). Areas de Potencial Productivo del Pinon Jatropha Curcus, L., Como Especie de Interés Bioenergético en Mexico; Boletin No. 16; Oleaginosa: Mexico City, Mexico, pp. 4-6. 


\section{CHAPTER 3}

The case of Kobre:

From jatropha to abandonment 


\begin{abstract}
In the past 10 years, large-scale jatropha investments and their implications for agrarian environments and rural livelihoods have received significant scholarly and policy attention. Using a case study this chapter contributes to literature by analysing the impacts of the jatropha trajectory from boom to bust, and the impact dynamics after jatropha failure and the abandonment of jatropha investment, and how the impacts of the failure could be incorporated into the analysis of agrarian change. Jatropha investment and failure in the case of Kobre, Ghana, shows how migrant farmers were evicted from the investment area, and that the investment failure and abandonment of the land did not result in the restitution of their land access. Rather, due to land conflicts instigated by the investment failure, the migrant farmers suffered from permanent exclusion from the land. The chapter calls for a critical evaluation of the impacts of large-scale land investments and their failure in socio-politically complex spaces in order to reorient agrarian change towards inclusive sustainable development.
\end{abstract}

Key words: biofuels; jatropha; landscape; migrants; indigenous people; large-scale investment; Ghana. 


\section{Introduction}

Pru East District is in Ghana's guinea savannah woodland zone, which is well known for fishing and agriculture and popularly known as one of the country's food baskets. The territory is a mosaic of tall grassland and forest agriculture, characterized by small agricultural plots with patches of open and closed forest and woody fallow. The abundant water resources provided by Lake Volta and the rivers Kefoose, Sele, Pre, Kalekya and Nyelase support the year-round irrigation of small-scale agriculture, fishing and potential large-scale agriculture investment (GSS, 2014). According to a study by USAID (2017), in 2010-15, yam and cassava were produced in commercial quantities by approximately $66 \%$ of the population of the district, making it a part of the 'yam belt' (yam is the most important consumed staple food in Ghana).

The district is within the newly formed Brong East Region, which is in the north-eastern part of the former Brong Ahafo Region and covers about $3220 \mathrm{~km}^{2}$, constituting $5.6 \%$ of the region (GSS, 2014). The 1992 constitution of Ghana allows leasehold of the customary or traditional lands, thus embracing the coexistence of traditionalism and government-managed land administrative systems. The traditional paramountcies own about $80 \%$ of the land in Ghana; the remainder is owned by the government and private individuals (Amanor et al., 2008; Peters, 2010; Antwi-Bediako, 2018). Land administration in Pru East District is no different from the national landownership structure. There are five recognized traditional paramountcies in the district - namely Abease, Kojobofour, Konkoma, Prang and Yeji traditional paramountcies - and they own about $80 \%$ of the land in the district. The traditional system is hierarchical and land is acquired from the traditional paramount chief through the village chief. The village chief consults the divisional chief before communicating with the paramount chief (Figure 3.1). 


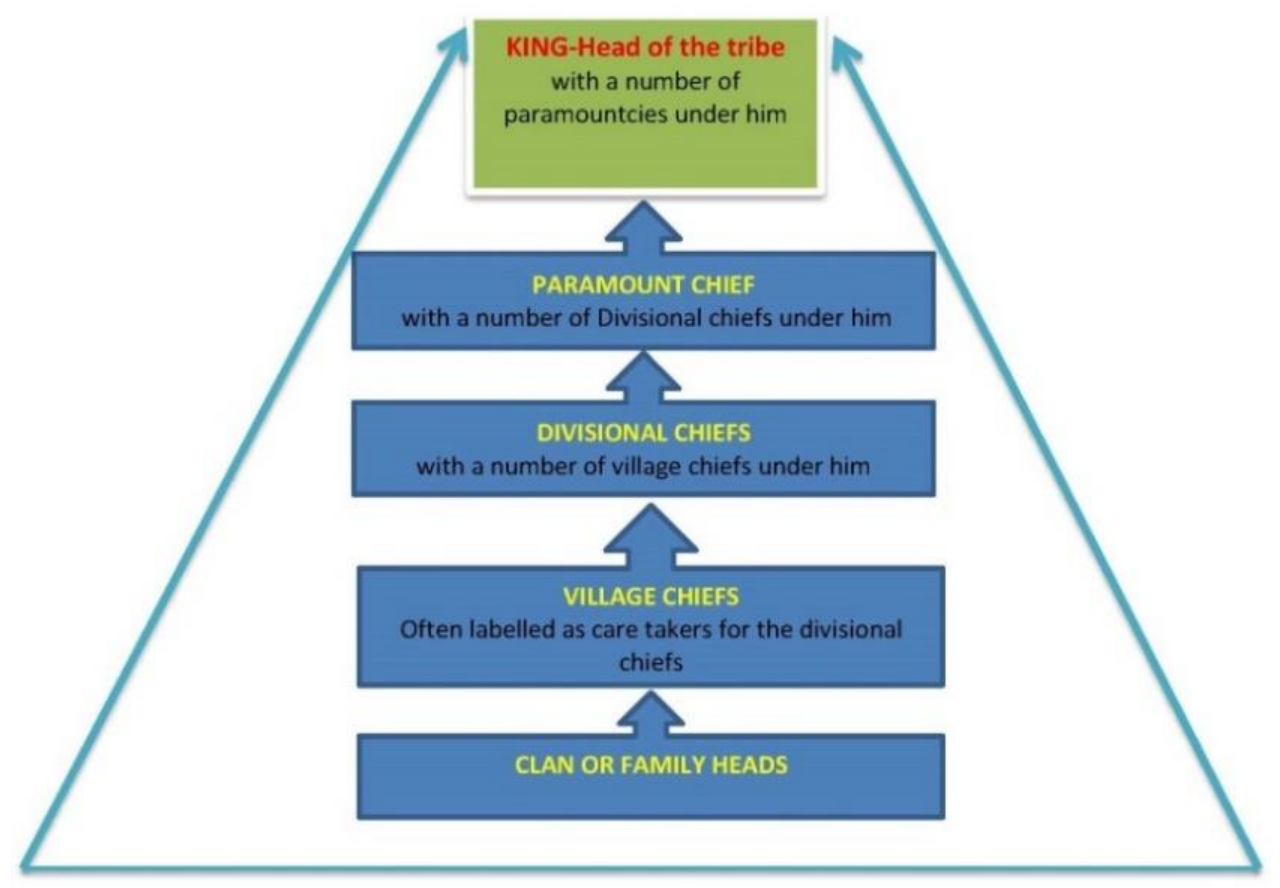

Figure 3.8: Ghana's traditional power structure and hierarchy

Source: Adopted from Antwi-Bediako, 2018

\section{Migration, land tenure and investments in Pru East District}

Pru East District has a mixed population of indigenous and migrant people, most of whom live in large towns such as the district capital, Yeji (Figure 3.2). About 23\% of the population are migrants, who tend to live in villages as farmers. The majority of the migrants in the district $(10,627$ out of a total population of 129,248$)$ came from the Northern Region; the rest are migrants from Volta $(5,952)$, Upper West $(3,645)$ and Ashanti $(1,829)$ regions (GSS, 2014). In 2010, migrants had lived in the district for as long as 19 years (ibid).

The migrants from the Northern Region entered the district in the 1980s. Migration was triggered by a number of reasons and push and pull factors during that decade, that is, long and persistent disputes over customary landownership between tribes, long-running violent conflicts over succession of chieftaincy (particularly between the Konkomba and Dagomba tribes), and relatively better farming prospects than in the arid Northern region, in that land in Pru East has a low population density and is located close to Lake Volta and its flood plains (see Figure 3.2) (Tonah, 2007). The practice of land tenure in the district includes shared cropping arrangements and annual ground rent in the form of provision of food produce, mainly 
yam, to the traditional paramountcy through the caretakers or community village chiefs (Tonah, 2007).

Pru East District became famous for its large-scale investments between 2007 and 2009, when four foreign agri-business investors acquired 152,500 ha, equivalent to $69 \%$ of the district's total land area, for jatropha and sugarcane cultivation (Schoneveld et al., 2011). Jatropha was a new crop to the district and it was introduced on such a large scale that it took centre stage. Specifically, in the area of Kobre, a Canadian company - Kimminic Company Limited - invested in the large-scale cultivation of jatropha, which changed the agricultural landscape and community dynamics.

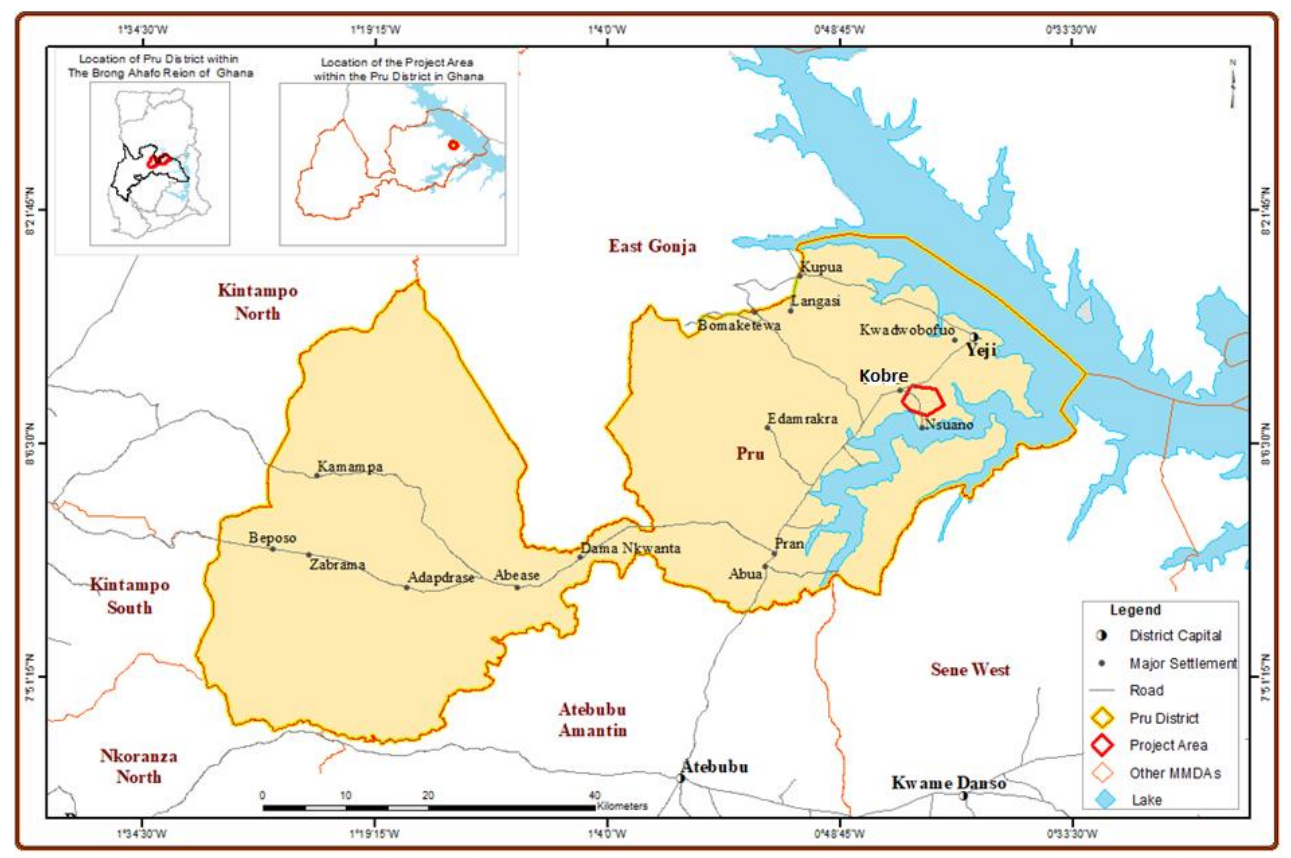

Figure 3.9: Map of Pru East District showing the project area near Kobre

Kobre is a small community of about 500 people (District Planning Officer, 2015), whose population is mainly made up of migrants from the Northern Region. The migrants acquired their land from the Kojobofour paramountcy. Kobre is about $20 \mathrm{~km}$ from the district capital (Figure 3.2) and it is quite isolated along the Atebubu-Yeji road, as the closest community, Prusu, is about $15 \mathrm{~km}$ away. Kobre is an interesting community worth understanding because 
of the dynamic changes that occurred after its exposure to the large-scale jatropha investment and the aftermath of investment failure.

This chapter discusses encounters between businesses and local indigenous and migrant people that have had a significant impact on the people's development agenda and their relationships. It identifies the impacts resulting from the creation of jatropha space, particularly on migrant farmers, as well as the impacts resulting from the total abandonment of this space. The chapter focuses on what has been created in the invested space since the business failure in relation to ecological, economic and socio-political changes.

\section{Methodology}

Within the project area of Kobre, data for this study were secondary and primary in nature. Secondary data sources were institutional documents and publications.

Table 3.1: Summary of project area in Kobre

\begin{tabular}{|c|c|c|}
\hline \multicolumn{3}{|l|}{ No } \\
\hline a. & Former land use & Cropland, grazing \\
\hline b. & Ecological zone & Guinea savanna-woodland \\
\hline c. & Water management for agriculture & Rain-fed and small-scale irrigation \\
\hline d. & Average temperature & $28^{0} \mathrm{C}$ \\
\hline e. & Soil type & Sandy loam \\
\hline f. & Land acquisition process & Through broker \\
\hline g. & Compensation issues & No \\
\hline h. & Consultations with communities & No \\
\hline i. & Land title type & Lease \\
\hline \multirow[t]{7}{*}{ j. } & Jatropha investors name & Kimminic Company Limited \\
\hline & - Investor origin & Canada \\
\hline & - Start year & 2007 \\
\hline & - Year of abandonment & 2011 \\
\hline & - Land acquired & 13,000 ha \\
\hline & - Land cultivated & 960 ha \\
\hline & - Number employed in peak season & 350 \\
\hline k. & After Jatropha & Abandonment \\
\hline
\end{tabular}


In 2014, preliminary surveys and actual fieldwork started with the collection of primary data. An interview guide, focus group discussions and participant observations were used to collect the primary data from the respondents; this was complemented by telephonic contacts and audio recordings. Respondents selected for the study in Kobre met the following set of criteria: must be a locally resident (indigenous or migrant) farmer and a local resident who had lived in the community for at least four farming seasons before the commencement of the jatropha investments.

Table 3.2 Key informants and participants in focus group discussions (FGDs) in Kobre

\begin{tabular}{|c|c|c|c|c|}
\hline Kobre & Type of respondent & $\begin{array}{c}\text { FGD } \\
\text { participants }\end{array}$ & $\begin{array}{c}\text { Key informant } \\
\text { interviews }\end{array}$ & Total \\
\hline Subtotal & $\begin{array}{ll} & \text { Kimminic employees } \\
\text { (company workers) } \\
\text { - } & \text { Farmers } \\
\text { - } & \text { Ministry of Food and } \\
\text { Agriculture } \\
\text { - } \\
\text { - } & \text { Traditional land owners } \\
\text { - } & \text { Broker }\end{array}$ & $\begin{array}{c}14 \\
8\end{array}$ & $\begin{array}{c}1 \\
9 \\
2 \\
6 \\
4 \\
1 \\
23\end{array}$ & \\
\hline Total & & & & 45 \\
\hline
\end{tabular}

Key informant interviews and FGDs were conducted to understand the concerns and complexities within the study area, which include information on how they were affected by jatropha investments and their abandonment. Each interview lasted 30-60 minutes. Primary data were collected mostly by note taking and audio recordings. The key informants were selected through both purposive and snowballing sampling techniques.

\section{Key informant interviews}

To gain an impression of the study area, face-to-face interviews were conducted with 23 key informants in 2014-18. The key informants were one representative from Kimminic Limited, nine individual farmers who were directly affected by the investment abandonment, two key government officials connected to the project at the district level, six traditional landowners and stool land representatives who had taken part in the land negotiation and acquisition process, four Assembly members from the districts affected by investment abandonment, and one broker who had played a role in the acquisition of land and agri-investment projects in the study areas. 


\section{Focus group discussions participants}

In 2014-18, three rounds of FGDs were conducted to explore the direct and indirect impact trajectories of jatropha investment and the aftermath of jatropha investment abandonment. The participants were 14 company employees who had been engaged in large-scale land acquisition and investment in jatropha spaces and eight farmers who were directly affected by the investment abandonment or diversification. In order to interview respondents directly affected by investments and investment abandonment, farmers and employees were sampled based on these criteria: must be a resident of Kobre and have lived in the Kobre community for at least four farming seasons before the commencement of the jatropha investments. The in-person focus group discussions were composed of eight participants to ensure greater control of the discussion subjects and allow each participant ample time to share their views and insights (Manoranjitham \& Jocob, 2007). The respondents' views were used to understand community land use patterns before and during the jatropha investment.

The first point of contact in 2014 was the assemblyman of Kobre, who was chosen due to his knowledge of the investor's operations. The assemblyman identified other community members who could assist in identifying and interviewing other community members who were affected by jatropha investment and its transformation. The respondents were jatropha workers/employees, affected migrants and landowners, who were interviewed for relevant data. The District Assembly planning officer of Pru East District was also interviewed because he had substantive knowledge of the land acquisition process and investment outcomes of jatropha in the area. After the failure of the investment, abandoned plots were intermittently observed during field studies in 2014-18 to evaluate the landscape and the socioeconomic situations of the people of Kobre.

\section{Results}

\subsection{Historical trajectories of jatropha space in Pru East District.}

As part of the 1980s migration, migrants - mainly Sisalas, Kokombas and Dagaabas from the Northern Region - acquired land from Kojobofour paramountcy and settled in Kobre. Konkoma and Kojobofour paramountcy trace landownership to their unique historical trajectories, a history that is not officially documented but commonly known and upheld by these diverse groups of indigenous peoples. The Kojobofour group migrated from southern Ghana and claim they have descended from the Akan lineage, whilst the Konkoma group is a mix of Guans from coastal Ghana and Konkomba from northern Ghana, who moved to Yeji and subsequently integrated through inter-marriage, becoming one group. 
These two paramountcies claim ownership of Kobre farmlands, but for some reason, migrants contacted a broker when they first arrived. The broker was associated with Kojobofour paramountcy; hence, the migrants were subsequently linked to Kojobofour paramountcy for land acquisition and gained unlimited rights to cultivate virgin farmland for yam and cassava in exchange for an annual rent of 10 tubers of yam, two bottles of schnapps per household and one sheep from the whole community. For this reason, the migrants owe allegiance to Kojobofour paramountcy. The occupation of Kobre farmlands by migrants and their allegiance to Kojobofour paramountcy progressively led to litigation between the Konkoma and Kojobofour paramountcies even before the jatropha investment. The migrants did not know about this litigation; only the chiefs or caretakers knew.

Most migrants built and dwelt in mud houses after obtaining land from the Kojobofour paramountcy. The migrants saw themselves as one group, instituting one member as its head to effectively engage with the representative (caretaker) of Kojobofour paramountcy on tenure issues. Team spirit, unity of efforts and group-based initiatives are common characteristics of the migrants living in Kobre. They used the land to produce food crops, especially yam, cassava, vegetables and maize for the local market. The vast area of land still had some areas to be cleared and used by migrant farmers. According to farmers, these areas were covered with vegetation and other green resources such as medicinal plants and herbs for local use. The migrant farmers cultivated 1.6- to 2.4-ha plots to feed themselves and to sell at the market, mainly at Prusu or the district capital, Yeji, helping them to support their households.

Here in Kobre, the land was used for crop farming before the investors came. We the migrants were involved in crops, especially yam, which were produced and sold in Yeji market, our district capital. (FGDs, farmers, Kobre, 2015)

The migrants produced to feed themselves, but generally their living standards were poor as they lived in dilapidated mud houses just along the main road passing through Kobre to Yeji. (Interview, assemblyman, 2015)

Members of the land-owning paramountcies - indigenous people - mainly lived in Kojobofour, Konkoma and Yeji, and were mostly not involved in the utilization of the land. Instead, they benefited hugely from the migrant farmers, buying non-competitively from them and dictating the prices of food products, and selling produce such as yam, maize, vegetables and cassava to major buyers from the cities. 


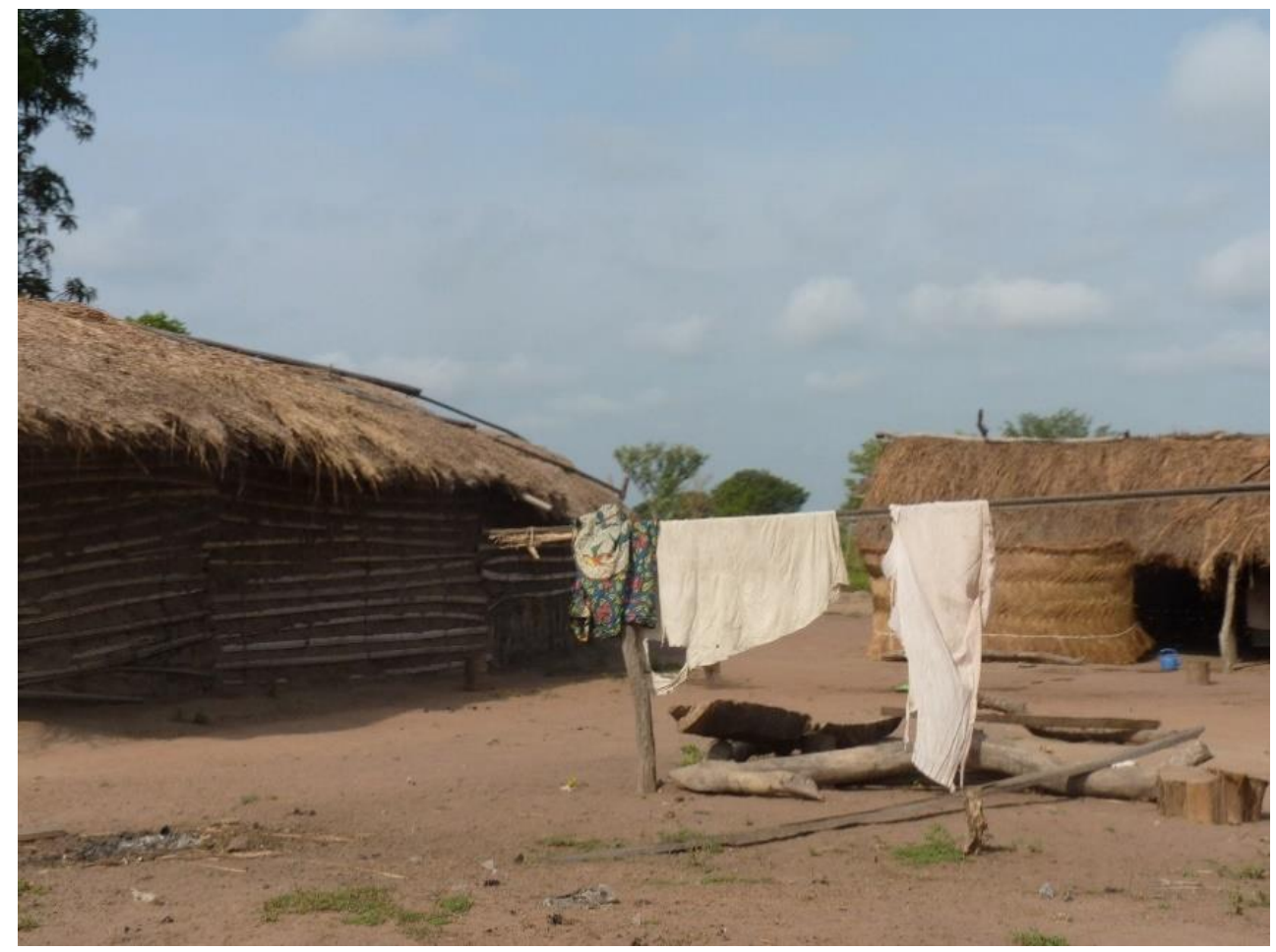

Photo 3.19: Migrants' housing units at Kobre

Source: Field Survey, Author (2015)

\subsection{Entry of the jatropha investment in Kobre}

In 2007, a management consultant, George Amponsem - a Ghanaian who had become a naturalized Canadian and was searching for a non-fossil fuel source - had the idea of starting a jatropha plantation to feed the renewable fuel market. In March that year, George registered a jatropha investment company - Kimminic Corporation - in Ghana. George had worked for Price Waterhouse Coopers (PWC) as a consultant for seven years and had experience in business planning, but not in farming or the oil business. Despite this, he launched the business in Ghana with a start-up of $\$ 16$ million. The plan was to fully integrate all aspects of the jatropha value chain from cultivation to market, and become vertically integrated. In order to meet targets in the last item in the chain, Kimminic registered as a free-zone company to export at least $70 \%$ of its produce and use the rest in the domestic market.

In mid-2007, Kimminic went through the process of acquiring land for the cultivation of jatropha in Brong East Region. First, it acquired land from the paramount chief of Nkoranza, 
in Nkoranza South municipality adjacent to Pru East District. In 2008, it acquired an additional 13,000 ha in Kobre through a broker. In Ghana, brokers largely facilitate the acquisition of land. In most cases, brokers are elites in the cities and mostly the first point of contact for investors. In this case, the broker was the first point of contact and part of the traditional paramountcy of Konkoma. George was introduced to the Konkoma paramountcy for the land negotiation and acquisition process and paid an undisclosed amount to the head of the Konkoma traditional paramountcy to acquire the 13,000 ha.

In early 2008, Kimminic started jatropha cultivation by clearing about 960 ha in Kobre. To improve the farm investment and agronomic practices of Kimminic within the value chain of jatropha, Kimminic relied on the extensive knowledge of Kofi Marfo.

Kofi Marfo had already established a biofuel company, and had knowledge of advanced management, remuneration and control systems, which he used as a leverage to head Kimminic Corporation in 2009. (Interview, assemblyman, 2015)

By late 2009, an oil refinery that had the capacity to process 400 tonnes of jatropha seed (equivalent to the amount produced on 80,000 ha) per day had been built to process jatropha seeds for the export market. By 2010, Kimminic was the most successful jatropha cultivation company in Ghana, with a functioning large-scale jatropha investment fully integrated in the whole value chain of jatropha (Nygaard \& Bolwig, 2018).

\subsection{Impacts of jatropha investment}

The jatropha investment by Kimminic in Kobre had three major impacts, namely it changed the tenure arrangement for migrant farmers and had conflict implications, it deprived migrants of their main livelihood source through land alienation, and it had an ecological impact.

\section{Tenure arrangement and land conflicts}

When Kimminic's employees first arrived at the project site with machinery to start the operation, they met with opposition from the Kojobofour group, because Kimminic had acquired the land from the Konkoma traditional paramountcy, who were contending with Kojobofour for the same land. This triggered a conflict between the Konkoma and Kojobofour paramountcies, as the Kojobofour traditional paramountcy also claimed ownership of the jatropha land. The migrants who were allowed to cultivate under the Kojobofour paramountcy 
did not know about the dispute over land in Kobre. They suddenly found themselves asked by Konkoma paramountcy to leave the land so that an investor could cultivate it.

Despite the conflict between the two paramountcies, Kimminic went ahead with preparing the land and cultivating jatropha. The migrant farmers were alienated from their lands in 2008 and started exploring the district for alternative lands. The leaders of Kojobofour paramountcy were enraged by the outcome of the land acquisition by the Kimminic and the subsequent alienation of migrants, and reacted by going to the court of law.

If they were serious investors, they should have delved deep to find out about who the true owner was. If they need land, the first thing is to see the Kobre chief or caretaker of Kobre and ask for the right thing to be done. Alternatively, even seek information from the community members from Kobre. We had no option than to litigate in court. (FGD, opinion leaders from Kojobofour, 2014)

Even though the issue was being litigated in the court of law, the conflict was unresolved because in 2008, the paramount chiefs of Konkoma and Kojobofour paramountcies, who were leading the litigation, died.

The land is owned by the traditional groups of Kojobofour, and it is managed by the chiefs. This land is not part of the Konkoma traditional area. The chief of Konkoma is no longer alive, and the chief who reigned at the time of the start of the jatropha plantation is also not alive. (FGD, migrant farmers, Kobre, 2016)

The litigation between Kojobofour and Konkoma paramountcies induced various issues between the Kojobofour paramountcy and migrant farmers. The key issue was the migrant farmers' demand that the Kojobofour leadership make available alternative lands for migrants in Kobre. The leadership of Kojobofour paramountcy, who claimed that they had not caused the eviction of the migrants from their farmlands, eventually refused this demand. The leadership of Kojobofour paramountcy asserted that it was the illegal interference by the Konkoma paramountcy that caused Kobre migrant farmers to lose their land. This marked the beginning of using local citizen status against the migrant Kobre farmers. Local citizenship status was invoked, creating a distinction between migrants and indigenous people. 
Why should we have to bear the responsibility of giving them new farmlands? If they want new lands to farm on, they have to renegotiate as migrants. (FGD, opinion leaders and representatives of the landowner, Kojobofour, 2016).

The Kojobofour paramountcy was adamant that it would not give alternative lands to the migrants, as the call from the leadership of the paramountcy requires a new payment for 'drink' money and increased ground rent. This condition was considered economically harsh by migrant farmers and they contested it, but to no avail.

There was no way we could pay such a demand. Payment of five times more than what we were contributing initially. The only way for us as farmers, is to move to new places without such conditions from the landowners. (FGD, farmers, Kobre, 2016)

Subsequently, the unemployed migrants switched to trading goods mainly in Yeji. Other migrant farmers were able to reconnect to alternative lands at convenient locations under different traditional paramountcies in Pru East District. Also, a number of the migrant farmers in the community were forced to secure alternative lands from Kojobofour paramountcy under an unfavourable tenure arrangement, because these migrants were comfortable dealing with Kojobofour paramountcy due to their long-standing relationship and had few alternative options.

\section{Livelihoods}

Kimminic's main agenda for the district was employment creation and technology transfer. Whereas the migrant farmers were severely affected due to dispossession, many of them (about 350), mostly youths, were employed by the company. The migrants lost their livelihoods as farmers to Kimminic and ended up working as wage labourers. Their monthly wages were based on the number of days they worked and ranged from GHS 80 (USD 20) for low-grade workers (sprayers and other field labourers) to GHS 380 (USD 95) for high-grade workers (supervisors). In addition to community members from Kobre, more than 100 indigenous individuals from nearby communities also worked for Kimminic. With heavy equipment like tractors and biofuel refineries, the company fulfilled Kimminic's agenda on technology transfer agenda by providing training for most employees in agronomic practices related to jatropha cultivation, machine operation and repair, and the operation of tractors. Furthermore, Kimminic 
was the only biofuel company in Ghana that acquired equipment to build a biofuel oil extraction/processing facility in Kobre.

Apart from employment, there were some other co-benefits for the local people. For example, female vendors sold food and water to the workers at the jatropha farm sites. This contributed positively to the vendors' livelihood advancements, as they were able to obtain income from both the investor and the employees. However, there were some negative attributes, as indicated by jatropha workers:

Even though we were not willing to work for them, the only employable venture we could identify ourselves with was becoming wage labourers. We were fortunate to even be employed. At least we were employed as farm labourers with wages, even though they were meagre. Moreover, our wives could sell on farm sites to supplement the household income. (FGD, former plantation workers, Kobre, 2015)

Though most workers received an average wage of about 50 US dollars a month, the wages were not paid consistently every month ... there were some corrupt activities by the managers in relation to salary payment ... during the cultivation and plantation phases of the project, we were marked down for five hours of work even though we operated for only one hour, and when we are about to be paid, the managers would take the extra four hours salary and pay us for one hour. (FGD, former plantation workers, Kobre, 2015)

With these negative attributes, some of the wage workers left to look for alternative lands for farming even before the collapse of the investment.

\section{Ecological impacts}

The impact on vegetation was negative during the jatropha investment. Trees, tall grasses, shrubs, medicinal plants and herbs were all removed to make way for the plantations. Farmlands with food crops, notably vegetables and cereals, cultivated mainly by migrant farmers were transformed into jatropha plantations and the site of the processing factory and the Kimminic office. The migrant farmers' reliance on the land as a common pool resource was impacted, mostly because they were prevented from using the land for shifting cultivation, especially yam cultivation, and the collection of forest and non-timber forest products. 
The land was used by migrants for farming purposes. So, when the investor acquired the land, all the vegetation and crops were destroyed and replaced with jatropha [even though they had employment]. (A key informant, Kobre)

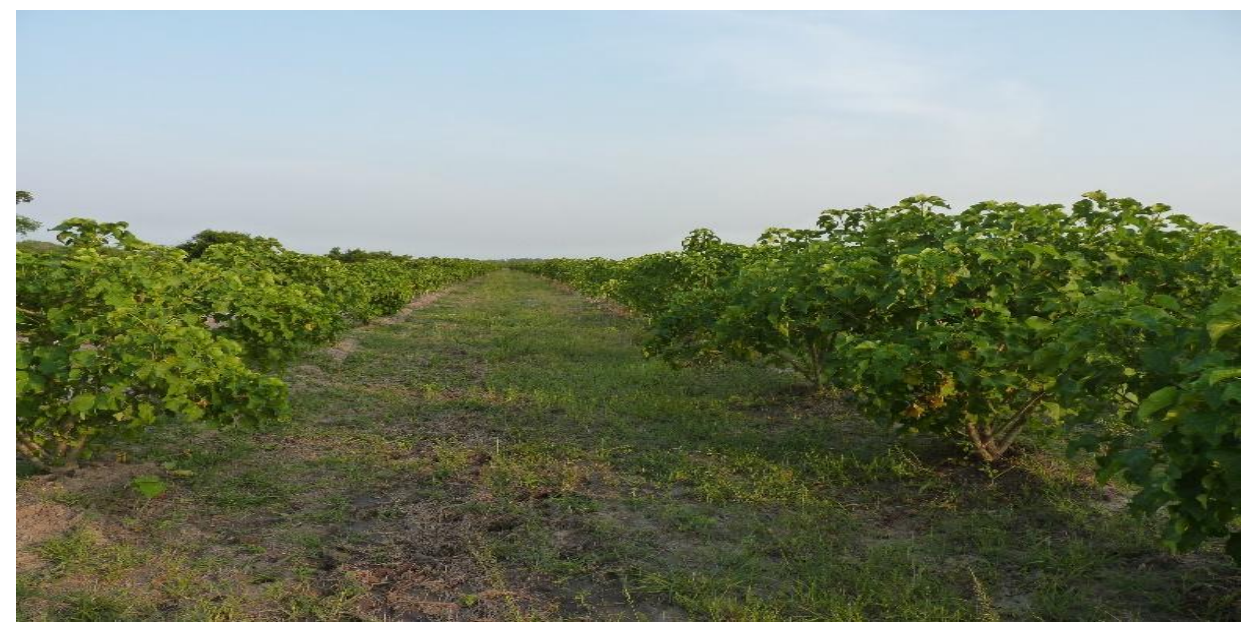

Photo 3.20: Kimminic jatropha farm during biofuels scoping campaign in 2009

Source: Field Survey, Author, 2009

\subsection{Abandonment of the jatropha space and its impacts}

The success of jatropha investment was short-lived. By 2011, Kimminic was facing several challenges and setbacks. Kimminic's financiers had refused a USD 3 million cash injection requested by Kimminic to sustain the business; there had been mismanagement of the investment; the export market had dried up due to the global jatropha bust; there was criticism from NGOs (Acheampong \& Campion, 2014); and the investors lacked experience in cultivating and processing jatropha and were new to the cultivation of biofuel feedstock like jatropha. Kimminic lacked experienced agronomists in the field of harnessing jatropha for better yield and profits, especially when they procured and built an oil extraction facility that cost the company huge sums of money and exceeded Kimminic's planned financial and investment model. This was tantamount to mismanagement of the funds by Kimminic management staff and a drain on the company's resources. Kimminic could not consistently pay workers' salaries as planned, and subsequently the latter could not repay their domestic loans. A lack of government tax incentives to serve as an added advantage for smooth financial management and reduction of operation costs also led to the collapse of Kimminic. All these setbacks led to Kimminic officially halting its investment operations in early 2012, and 
abandoning its assets, including, tractors, equipment and plants, which were seized by their domestic bankers (Photo 3.3). Kimminic totally abandoned the investment without paying its workers severance pay. This abandonment of the jatropha space further modified the impacts created by the jatropha investments, as described in the following paragraphs.

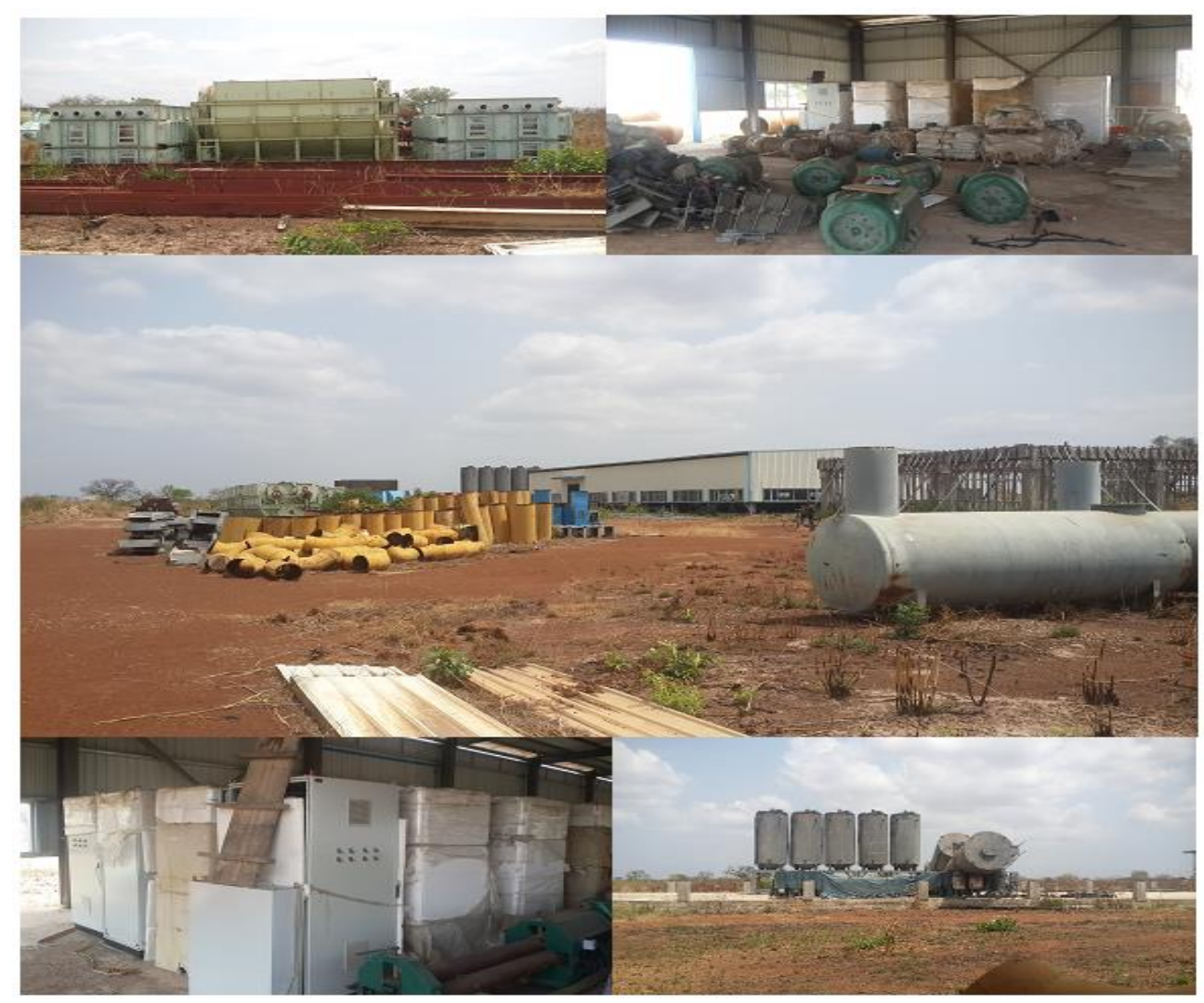

Photo 3.21: Some of the abandoned infrastructure after the abandonment of the investment Source: Fieldwork, Author, 2016

\section{Tenure arrangement and land conflicts}

Tenure arrangements continued to be an issue for the migrants after the abandonment of jatropha. The two paramountcies will not allow the migrants to farm the land until the litigation in the court of law is settled. In addition, some of the land had Kimminic's assets on it that had been seized by Kimminic's domestic bankers. The bankers also prevented Kobre farmers from farming in and around the zones where their equipment and offices are. With the collapse of 
Kimminic and the persistent conflict over the 13,000 ha of jatropha land, there was no reason for most migrants to stay.

... viewed from afar, I am sure that the jatropha crops have been replaced with other vegetation. The land is no longer in use by us, since there is conflict over who is the rightful owner of it. My family and I are now working at Yeji, helping my friend with fishing. (Migrant farmer, Kobre, 2017)

The migrants who attempted to secure alternative lands from Kojobofour could not afford the tenure arrangement and so migrated to new spaces where the tenure arrangement was reasonably priced.

\section{Livelihoods}

In the phase of investment abandonment in Kobre, rural livelihoods were not guaranteed for migrants for a number of reasons. The aftermath of investment was beset by a long-standing land conflict and litigation between the Konkoma and the Kojobofour paramountcies. With both claiming ownership of the investment spaces, migrants - the original land users - were prohibited from farming the land. This affected the migrants' livelihoods and had a number of consequences, including the migration of farmers from Kobre in search of alternative jobs and land for farming, leading to the depopulation of Kobre village and other agglomeration effects, such as child labour in the fishing communities around Yeji.

Thus, investment abandonment did not create opportunities for community members in Kobre to reconnect with abandoned jatropha land for economic activities; rather, it triggered internal mobility from Kobre to other rural communities in Pru East District. For instance, migrant women who used to depend on other agriculture-related activities as their sources of livelihood - such as the collection and sale of firewood, wild fruits and herbs on the investment land - were affected by the prohibition on accessing the investment land. This supports the assertion by Behrman et al. (2012) and Tsikata and Yaro (2011) that in the event of investment, women whose activities are limited to the gathering and selling of agricultural products such as medicinal herbs tend to have their activities halted, which pushes them further into poverty and vulnerability. Many of the affected community members moved to adjoining communities and districts in search of economic opportunities. 


\section{Ecological impacts}

Personal observation and the community's perspective revealed three main ecological consequences: vegetation homogenization, vulnerability to harsh conditions and the exposure of vegetation to annual bushfires, and the loss of indigenous species. The land is now covered with desiccated short grass and jatropha plants (Photo 3.4), which are vulnerable to annual bushfires that destroy most indigenous species.

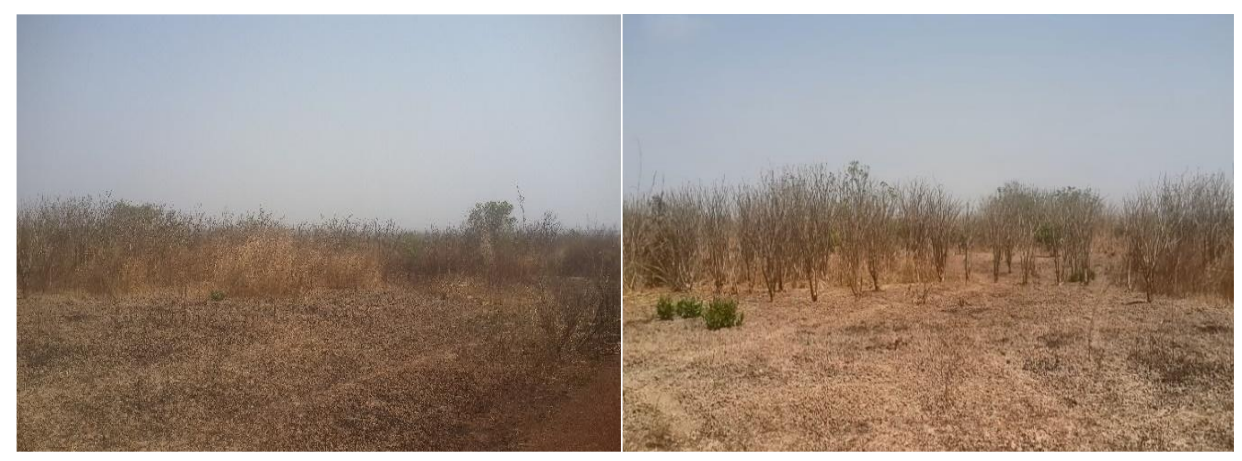

Photo 3.22: Landscape after abandonment

Source: Fieldwork, Author, 2016

Table 3.3: Summary of the impacts of jatropha investment after its abandonment in Kobre

\begin{tabular}{lllll}
\hline No $\begin{array}{l}\text { Impact } \\
\text { classification }\end{array}$ & & \multicolumn{2}{c}{ Description } \\
\cline { 3 - 4 } & & Before investment & During investment & $\begin{array}{c}\text { After abandonment of } \\
\text { investment }\end{array}$ \\
\hline $1 \quad$ Tenure & Migrant farmers & - Investors acquired & - Land abandoned by \\
and & acquired land & 13,000 ha from & investor, but investor \\
land conflict & from Kojobofour & Konkomba & left without giving \\
& as landowner & without & tenure right to \\
& Land tenure & consulting the & migrant farmers to \\
& arrangement & community head & reuse \\
& between & - Migrant farmers & - No migrant farmer \\
& indigenous & alienated and lost & could use land \\
& landowners and & right to use land & because of litigation \\
& migrant farmers & - Limited & between the two \\
& through land rent & opportunities for & litigating \\
\hline
\end{tabular}




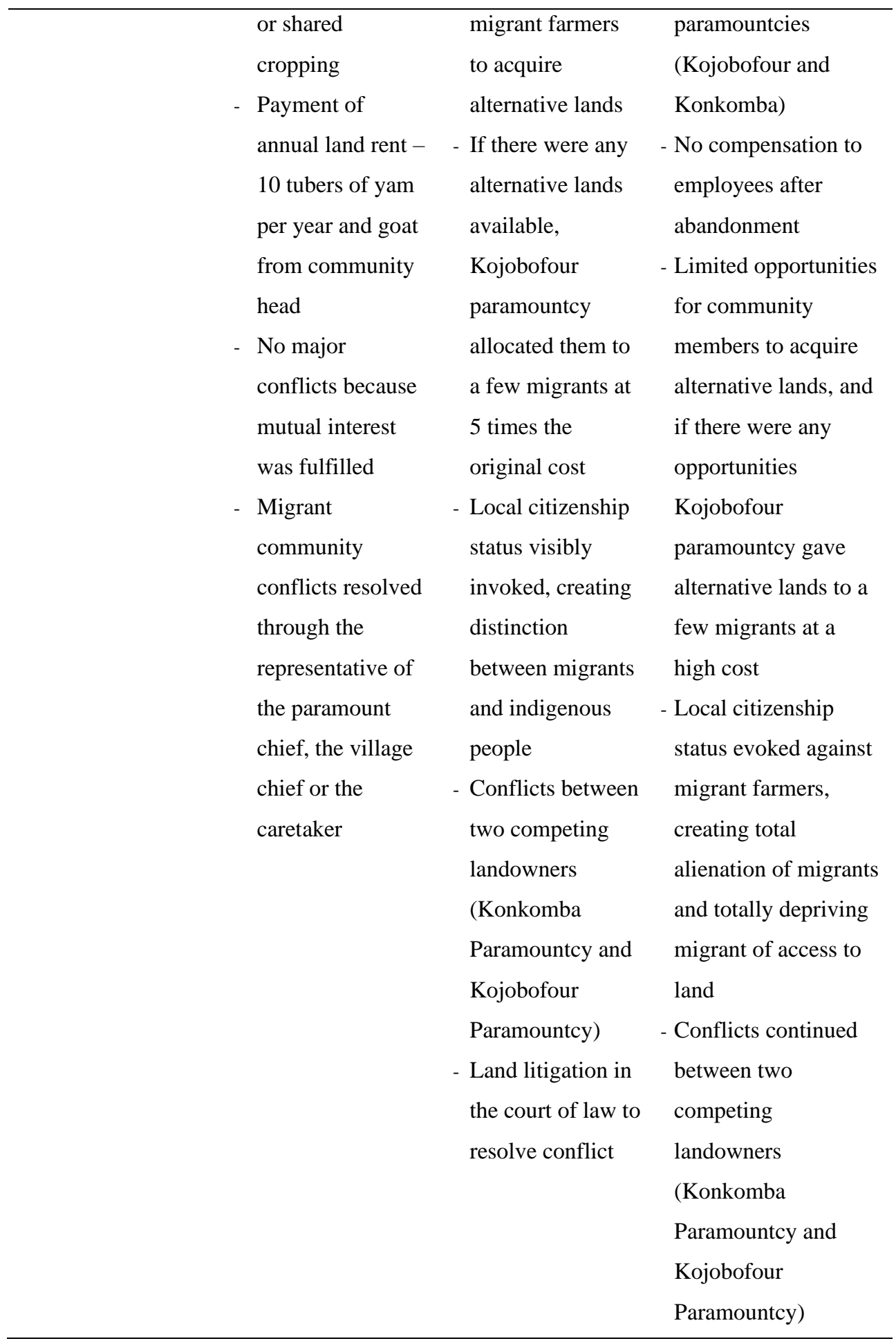


- Land litigation in the

court of law to

resolve conflict

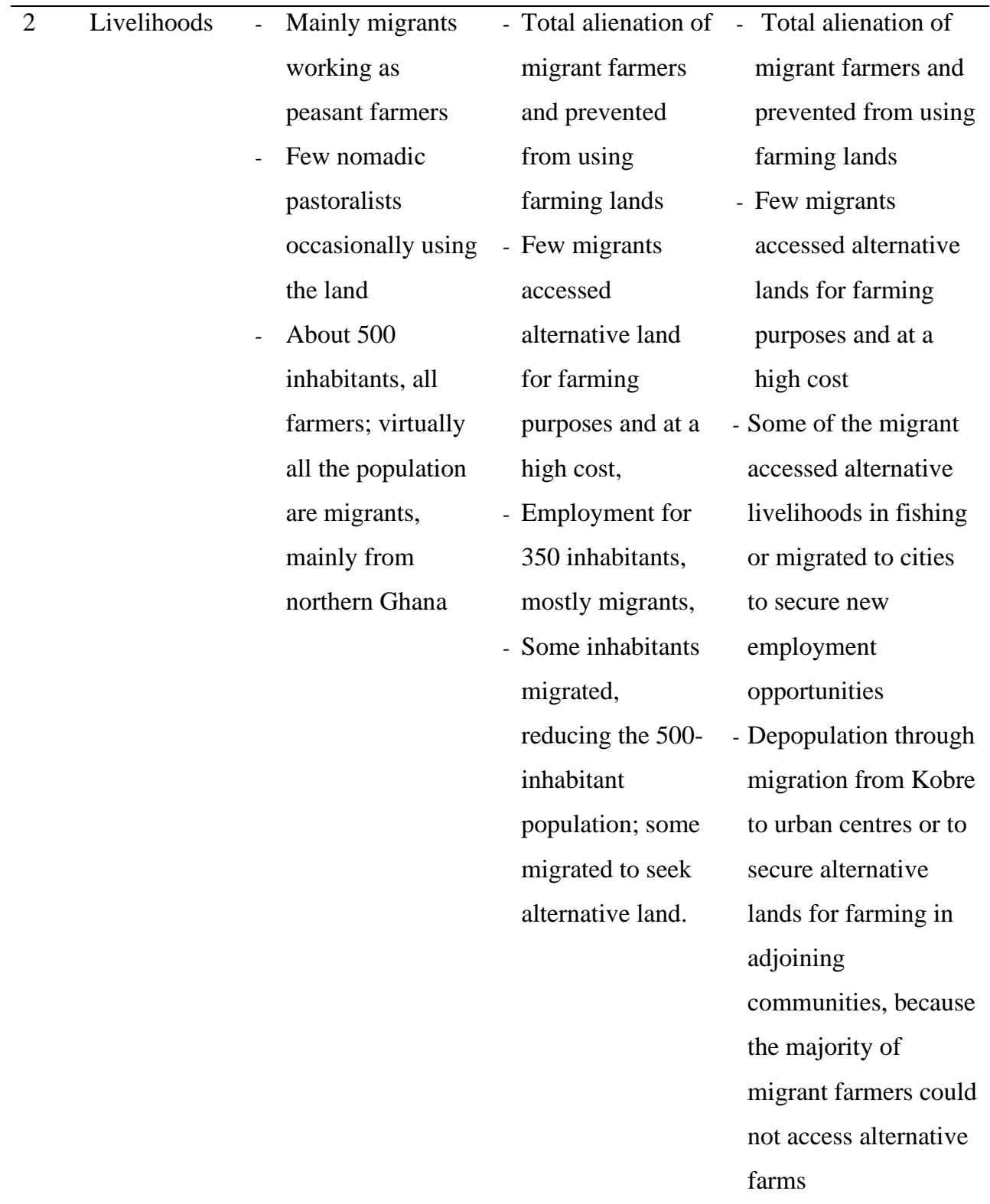

\begin{tabular}{|c|c|c|c|c|}
\hline 3 & $\begin{array}{l}\text { Ecological } \\
\text { change }\end{array}$ & $\begin{array}{l}\text { - Flat landscape } \\
\text { - Forest agriculture } \\
\text { mosaic }\end{array}$ & $\begin{array}{l}\text { - 1,000 ha } \\
\text { homogenized with } \\
\text { jatropha }\end{array}$ & $\begin{array}{l}\text { - Dry homogenized } \\
\text { landscape } \\
\text { - Annual bushfires }\end{array}$ \\
\hline
\end{tabular}




\begin{tabular}{ll}
\hline & Patches of open $\quad-12,000$ ha unused \\
& and closed forests, by either farmers \\
& and woody fallow $\quad$ or investors \\
- & Small agricultural \\
& plots \\
- & Water resources \\
& $($ e.g. Lake Volta \\
& and the rivers \\
& Kefoose, Sele, \\
& Pre, Kalekya and \\
Nyelase $)$ &
\end{tabular}

Source: Author, 2019

\section{Discussion}

The case of Kobre in Pru East District shows that the jatropha investment and abandonment created conflicts and impacted tenure arrangements, livelihoods and the environment, which led to the total marginalization of, limited opportunities for and then the permanent exclusion of Kobre migrant farmers and exacerbated the dry condition of the ecological landscape. The local impacts were mostly negative, as land as an asset for rural growth and subsistence was transformed through massive investment. There is no doubt that large-scale agri-investment in Kobre caused huge changes in the local context that particularly affected rural migrants and the ecological landscapes.

\subsection{Exclusion and marginalization}

The study shows that the absence of inclusiveness from large-scale investment can increase the marginalization of vulnerable groups. The results indicate that before the investment, the tenure arrangement was inclusive. Migrants in Kobre and some of the indigenous population were in consultation with the Kojobofour paramountcy, and once they met the set conditions, access to and control over land were granted. Exclusion and marginalization materialized when jatropha investment began in 2008. Identity status was only used in Kobre when the KojobofourKonkoma litigation started, leading to the marginalization and exclusion of migrant farmers from any tenure arrangement and land use.

As indicated by Lund (2011) and Berry (1989), identity status spearhead in the mantra 'local citizens' is used as a discriminatory tool against migrants. Historically, 'local citizenship 
status' was derived by individuals who have a strong informal understanding and belief that they were the first to identify and settle on a piece of land (Lund, 2011). Thus, migrants are seen as new arrivals and should be treated separately and quite abusively in terms of access to and use of communal properties such as land. This was triggered in Kobre, as lands that were occupied by migrants were taken over, and their reconnection to other resourceful lands was only possible by meeting unfair economic conditions. External influences of the large-scale investment worked to break the social relations that usually result in gains for the stronger - in this case, the indigenous people/land-owning paramountcies - to the detriment of migrants. In Kobre, the indigenous people were able to dictate land prices and tenure arrangements to their advantage. The Kojobofour's insistence that migrant farmers should pay additional money to requalify for access to and use of lands in Kobre is a clear manifestation of partiality against the migrants, as they lacked the financial strength to meet these exorbitant tenure arrangements.

Migrants initially had communal rights as they met the locally agreed conditions for access to and use of land. However, they were not notified of the impending jatropha investment in Kobre. With the use of this discriminatory regime, migrants saw themselves as inferior and perceived the indigenous population as their superiors, who could help them to obtain alternative lands for their farming activities. As indicated by the results, the aftermath of investment failure triggered the unexpected alienation of migrant farmers from the land. The dispute between the two paramountcies over the investment land weakened the existing relation between migrants and the indigenous population. The dispute continued after the abandonment of the investment. The bonding relations amongst the indigenous population weakened through the exposure of unresolved conflicts between the Kojobofour and Konkomba paramountcies.

Conflict generated amongst the local leaderships of Kojobofour and Konkomba paramountcies, and clan heads, reveals the social vulnerability of the communities. The social inclusivity towards marginalized groups of people such as migrant farmers is an important bedrock for sustainable community peace and coexistence (Gupta et al., 2015), but the conflict amongst the local leaderships made social inclusion unachievable. To ensure inclusive sustainable development, it is imperative for large-scale investors to implement, for example, inclusive business models and inclusive tenure arrangements to foster operational peace and local support for their projects. Migrants in Kobre, the landowning paramountcy (Kojobofour) and the indigenous population had customary systems that bonded them socially. When communities are able to build strong social relations, they are usually also able to harness efforts and resources to prevent external alterations to their social systems (Grootaert \& Thiery, 2002). As shown by Szreter and Woolcock (2004), the successful creation of good relationships 
can help rural communities to have frequent interactions with and support from power structures and institutions, which could spearhead their development. It is no surprise that the conflicts and land deals in the case of Kobre resulted in the creation of even more diverse social, economic and ecological complexities.

\subsection{Opportunities and livelihood arrangements}

The present study showed that the investment, which had an emphasis on poverty alleviation and food security, had a negative influence on local livelihoods and food security, thus affecting the achievement of the sustainable development goals regarding the reduction of poverty and hunger (Matondi, 2011; German et al., 2011; Cotula \& Vermeulen, 2009). Yet, it had some positive implications in terms of employment. Jatropha cultivation by Kimminic led to employment opportunities for 350 workers, mostly migrant farmers from Kobre. In addition, the sustained conflicts between two customary landowning paramountcies and the abandonment of the 13,000 ha of land, led to the land lying fallow for a long period and thus increasing in soil fertility.

Land conflicts also disrupt livelihood arrangements by preventing community members from exploiting the land for farming purposes. If in such circumstances there are no alternative solutions to mitigate the situation, the land is abandoned. Kobre agricultural land was subject to conflicts and litigation during and after the jatropha investment, and there were not enough opportunities for migrant farmers to return to the land after the investment abandonment. Thus, the abandonment of the jatropha investment forced farmers to seek alternative land to escape the consequences of the decline in farm income, the shortage of food and dependence on unguaranteed alternative livelihoods and permanent exclusion from land use and opportunities. This triggered migrations from Kobre community to peri-urban centres like Yeji and Atebubu. Even though some of the migrants after migration from Kobre secured new economic opportunities, most of the migrants with their children ended up in the fishing community of Yeji. When poor migrants in Ghana are dispossessed and they relocate, this usually leads to child fostering (Imoh, 2012) because most of them lack the resources to feed their families. In these circumstances, migrants send their children to families and friends to be fostered in the Yeji fishing area, under undisclosed arrangements. Before the de-socialization of parents from children, children are taught how to earn money in order to mitigate the family distress.

The above confirms the words of the assemblyman of Kobre (2016), who said that the plight of some migrants led to child labour in the fishing community in Yeji, with children working in harsh and unsafe conditions as fishing assistants. These migrants are members of 
low-income households who are forced to migrate from the village to other land spaces within the region, or to the urban centres in search of jobs that require a high degree of skill. As such, most of them end up in peri-urban centres working as labourers. According to Vranken et al. (2004), the global phenomenon of rural community members seeking new economic opportunities in urban centres is caused by their being prevented from using abandoned agricultural lands. For instance, in Kobre, their disempowerment opened avenues for new economic opportunities like fishing and trading in Yeji and other market centres in urban areas.

\subsection{Accelerated dry conditions}

The study showed that the abandonment of the jatropha investment led to accelerated dry conditions, which led to bushfires, making the area unattractive for local socioeconomic activities. Local ecological resources make substantial contributions to local socioeconomic growth and development (Walker, 2005). This is because such resources serve as the main bedrock for the livelihoods of the local people (Watson et al., 2016). Studies by Zou and Shen (2003) and Myers et al. (2000) have also shown that the presence and preservation of the local ecology enhance social cooperation amongst local economic actors who commonly use such resources for sustenance. Rural communities depend extensively on ecological services for livelihood sustenance (Watson et al., 2006), and this makes ecological resources of substantial importance. The emergence of eco-sustainability projects in recent years tends to emphasize the need to streamline efforts to preserve ecological resources. Green resources play an instrumental role in liveability, social cohesion and economic regeneration for migrants and indigenous populations, as was the case in Kobre before the investment in jatropha. Prior to the exposure to the large-scale investment, the land was an economic asset (e.g. Obeng-Odoom, 2012; Matondi, 2011; Agbosu, 2000) and a place for community members to cultivate food.

However, the long rest period of the agricultural land after the abandonment led to different natural dynamics and transformation, including dry homogenous vegetation and regular bushfires. This aligns with Laiolo et al. (2004), who stated that the abandonment of agricultural land or allowing land to lie fallow for a long period may either homogenize or maintain the heterogeneity of the vegetation. However, exposure to large-scale agricultural land expansion and abandoned mono-crops leads to vegetation homogenization and reduced heterogeneity (Lasanta-Martínez et al., 2005). Observation from the study were corroborated by Lasanta-Martínez et al. (2005), who found that the exposure of land to long-term abandonment can lead to annual bushfires. None of these impacts were envisaged in the development of the jatropha investment or after its failure. 


\section{Conclusion}

The case study revealed the implications of large-scale investment for farmers, especially migrant farmers, and how abandonment of the investment created different dynamics of impacts in a jatropha space. This chapter also makes a unique contribution to literature on largescale agricultural investments by arguing that inclusive sustainable development cannot be achieved if large-scale investments and their abandonment have negative impacts on the social wellbeing and way of life of migrant farmers. It shows that jatropha investment generally had unpredictable negative implications on livelihoods and food security even though community members benefited from employment. The conclusion is that:

1) Large-scale investment can contribute to employment, which eventually improves the lives of rural community members, but can also create negative livelihood changes that adversely affect households' food security.

2) Large-scale investments may be accompanied by a benefit package for community members, but this package is temporary as most benefits disappear once the investment is abandoned.

3) Large-scale investment with a relatively high level of inconsistence between the truth and the promises of the investors and the expectations of affected farmers with unresolved local conflicts can provoke unexpected local complexities, which may result in changes in local land tenure arrangements and the social alienation of marginalized groups.

These implications have led to migrant farmers being unexpectedly excluded from practising what they know best. Thus, inclusive sustainable development can be achieved only if vulnerable groups (e.g. migrant farmers) are protected against tenure and social alienation as well as ecological impacts. Our results suggest reconsideration of inclusive sustainable development policies for large-scale agri-investment - policies that seek to promote the empowerment and protection of vulnerable farmers and decent living conditions for community members. In order to reorient agrarian change towards inclusive and sustainable development, policies promoting the empowerment and protection of local community members can be geared towards land rights for farmers during investment, partnership of 
farmers in commercial farming, and inclusive schemes such as contract farming and out-grower schemes.

\section{References}

Antwi-Bediako, R., Otsuki, K., Zoomers, A., \& Amsalu, A. (2019). Global Investment Failures and Transformations: A Review of Hyped Jatropha Spaces. Sustainability, 11(12), 3371.

Acheampong, E., \& Campion, B., 2014. The effects of biofuel feedstock production on farmers' livelihoods in Ghana: the case of jatropha curcas. Sustainability, 6, 45874607. http://dx.doi.org/10.3390/su6074587.

Agbosu, L.K. (2000). Land Law in Ghana: Contraction Between Anglo-America and Customary Conceptions of Tenure and Practices 1-3 (Land Tenure Ctr., Working Paper, No. 33).

Amanor, K., Ubink, J., \& Berry, S. (2008). Contesting Land and Custom in Ghana: State, Chief and the Citizen (p. 230). Leiden University Press.

Behrman, J., Meinzen-Dick, R., \& Quisumbing, A. (2012). The gender implications of large-scale land deals. Journal of Peasant Studies, 39(1), 49-79.

Berry, S. (2009). Property, authority and citizenship: land claims, politics and the dynamics of social division in West Africa. Development and Change, 40(1), 23-45

Cotula, L., \& Vermeulen, S. (2009). Land Grabs' in Africa: Can the Deals Work for Development. International Institute for Environment and Development Briefing.

German, L., George C. S., \&Pablo P. (2011). Local Social and Environmental Impacts of Biofuels: Global Comparative Assessment and Implications for Governance. Ecology and Society, 16 (4): 29.

Ghana Statistical Service-GSS (2014). 2010 Population and Housing Census. District Analytical Report; South Tongu District. Ghana Statistical Service (GSS), Accra.

Grootaert, C., \& Thierry, V. B. (2002). Conclusion: measuring impact and drawing policy implications. In V. B. Thierry (Ed.), the Role of Social Capital in Development (pp. 341 - 350). Melbourne: Cambridge University Press

Imoh, A. T.-D. (2012). From Central to Marginal? Journal of Family History, 37(4), 351- 363. doi:10.1177/0363199012440081

KITE, 2012. Assessment of biofuel producers in Ghana. Report prepared by KITE and commissioned by the UNEP Ris $\varnothing$ Centre (URC). 
Laiolo, P., Dondero, F., Ciliento, E., \& Rolando, A. (2004). Consequences of pastoral abandonment for the structure and diversity of the alpine avifauna. Journal of Applied Ecology, 41(2), 294-304.

Lasanta-Martínez, T., Vicente-Serrano, S. M., \& Cuadrat-Prats, J. M. (2005). Mountain Mediterranean landscape evolution caused by the abandonment of traditional primary activities: a study of the Spanish Central Pyrenees. Applied Geography, 25(1) 47-65.

Lund, C. (2011) Property and Citizenship: Conceptually Connecting Land Rights and Belonging in Africa. Africa Spectrum, 46(3), 71-75.

Manoranjitham, S. \&Jacob, S.K., (2007). Focus group discussion. Journal of the Nursing Association of India, 98(6), 125-127

Matondi, P. (2011). 'Argo-investments in Zimbabwe at a Time of Redistributive Land Reforms.' In Biofuels, Land Outsourcing and Food Security in Africa, edited by Prosper B. Matondi, Kjell Havnevik and Atakilte Beyene. New York: Zed Books

Matondi, P. (2011). Agro-investments in Zimbabwe at a Time of Redistributive Land Reforms. In Biofuels, Land Outsourcing and Food Security in Africa, edited by Prosper B. Matondi, Kjell Havnevik and Atakilte Beyene. New York: Zed Books

Myers, N., Mittermeier, R.A., Mittermeier, C.G., GaB, Da Fonseca., Kent, J., (2000). Biodiversity hotspots for conservation priorities. Nature, 403, 853-858.

Nygaard, I., \& Bolwig, S. (2017). Evolution of the Jatropha Biofuel Niche in Ghana. Technical University of Denmark: UNEP DTU Partnership. UNEP DTU Partnership Working Paper Series 2017, No. 1

Nygaard, I., \& Bolwig, S. (2018). The rise and fall of foreign private investment in the jatropha biofuel value chain in Ghana. Environmental Science \& Policy, 84, 224-234.

Obeng-Odoom, F. (2012). Neoliberalism and the Urban Economy in Ghana: Urban Employment, Inequality, and Poverty. Growth and Change, 43: 85-109, doi: 10.1111/j.1468-2257.2011. 00578.x

Peters, P. E. (2010). Contesting Land and Custom in Ghana. State, Chief and the CitizenEdited by Janine M. Ubink and Kojo S. Amanor. Journal of Agrarian Change, 10(4), 604-608.

Pru East District, 2019. Pru East District data. http://www.ghanadistricts.com/Home/District/47 
Schoneveld, G., German, L., \& Nutakor, E. (2011). Land-based investments for rural development? A grounded analysis of the local impacts of biofuel feedstock plantations in Ghana. Ecology and Society, 16(4).

Szreter, S. and Woolcock, M. (2004). Health by association? Social capital, social theory, and the political economy of public health. International Journal of Epidemiology, 33(4), $650-67$

Tonah, S. (2007). Managing farmer-herder conflicts in the middle Volta Basin of Ghana. In S. Tonah (Ed.), Ethnicity, conflicts and consensus in Ghana (pp. 240-260). Accra: Woeli Publishing Services.

USAID, 2017. The Feed the Future. Ghana District Profile Series is produced for the USAID Office of Economic Growth in Ghana by the Monitoring, Evaluation and Technical Support Services (METSS) Project. February 2017 - Issue 1

Vranken, L., Noev, N., \& Swinnen, J. (2004). Fragmentation, abandonment, and co-ownership: transition problems of the Bulgarian land market. Quarterly Journal of International Agriculture, 43(4), 391-408.

Walker, P.A. (2005). Political ecology: where is the ecology? Progress in Human Geography 29(1), 73-82

Watson, J.E.M., Shanahan, D.F., Di Marco, M., Allan, J., Laurance, W.F., Sanderson, E. W., Mackey, B., Venter, O. (2016). Catastrophic declines in wilderness areas undermine global environment targets. Current Biology, 26, 2929-2934.

Tsikata, D. and Yaro, J. (2011). Land market liberalization and trans-national commercial land deals in Ghana since the 1990s. In International Conference on Global Land Grabbing, 6, 8.

Zou, C.X., and Shen, W.S. (2003). Advances in ecological security, Rural Eco-Environment, $19(1), 56-59$. 


\section{CHAPTER 4}

The case of Agogo:

From jatropha to maize 


\begin{abstract}
The findings presented in academic literature on rural land tenure and agri-investment often reveal the inequality of land control, land conflicts, and the exclusion and alienation of local land users. However, the aftermath of large-scale agri-investment failure and investment diversification does not feature prominently in this literature. The aim of this chapter is to show the historical trajectories of agrarian investment from pre-investment to post-investment failure to reveal the knowledge gap surrounding the investment diversification in the jatropha space of the Agogo Traditional Area. The chapter discusses significant encounters marked by conflicts between local farmers and pastoralists (Fulani herdsmen) since the 1980s, and how jatropha investment in 2007 and investment diversification into maize since 2011 have triggered various forms of unpredictable local agrarian transformations in the area. The chapter presents lessons from investment diversifications to respond to the demands for inclusive sustainable development in large-scale investment spaces where local migrant/indigenous farmers and pastoralists coexist.
\end{abstract}

Keywords: Large-scale investment, land, conflict, tenure, pastoralists, Fulani herdsmen, migrants 


\section{Introduction}

The Agogo Traditional Area has undergone various forms of transformation since the 1980s, with local migrations and local agrarian change, large-scale agri-investment, investment failures and investment changes. In 1983, bushfires transformed the area from forest into land suitable for agriculture and cattle grazing (Amissah et al., 2010; Nsiah-Gyabaah, 1996; Hawthorne, 1994; Ampadu-Agyei, 1988). This triggered the migration of pastoralists - mainly nomad Fulani herdsmen and migrant farmers from northern Ghana - to the area, and they acquired lands through the traditional authorities. The two migrant resource users - pastoralists (Fulani herdsmen) and migrant farmers - coexisted but their coexistence was marked by violent conflict from the 1990s (Gyesi Zadok, 2017; Nhyira FM, 2017; Kaledzi, 2016). In 2007, largescale agri-investors commenced investments in these volatile spaces, notably where investors cultivated jatropha and food crops.

Before the major bushfires, Agogo had been known for its cocoa production and tropical forest, but a low annual rainfall led to dry, harsh conditions and Ghana was plagued with bushfires. The destruction of the tropical forest vegetation resulted in a new tropical savanna landscape. After the bushfires, the Agogo Traditional Area became a well-known centre for agriculture investment, including pastoralism, small- and large-scale investments in food crops and biofuel feedstock, and teak plantations for export because of the receptiveness of the landowners and the suitability of the land for agriculture, plantations and grazing.

In this process of agricultural development, migrants - mainly Kokombas and Dagaabas from the northern part of Ghana - migrated to Agogo and started to cultivate maize, plantain and other staple foods. With these migrations tilted towards agriculture, Agogo earned its name as one of the country's food baskets, producing most of the staple food and cash crops in Ghana, for example maize, rice, plantain, cassava, tomatoes, garden eggs (egg-shaped white aubergines), oil palm and oranges. Maize production increased from 11,331 metric tonnes in 2010 to 15,324 metric tonnes in 2012, making the district one of the main maize-producing districts in Ghana.

At the same time, pastoralists - mainly Fulanis - migrated from Burkina Faso, Niger, Nigeria and Benin to Agogo (Tonah, 2005). With the influx of Fulani herdsman, livestock became a major component in the district. For example, cattle stock increased from 1,500 head of cattle in 2010 to 2,100 in 2012, making the area a significant meat-producing enclave for Ghana (GSS, 2014; GoG, 2014).

Since 1990, the Agogo Traditional Area has been in the media spotlight for nonconsensual dispossession through large-scale investments in jatropha and maize, and violent 
conflict between pastoralists and farmers (Gyesi Zadok, 2017; Nhyira FM, 2017; Kaledzi, 2016). According to Olaniyan et al. (2015), there were extremely violent conflicts in 2001, 2002, 2004 and 2009, with lesser conflicts continuing until 2011, necessitating the intermittent deployment of soldiers to calm things down. In the midst of these conflicts, in 2006 large-scale jatropha investments and forest plantations started appearing in the area. The major players in this were Miro Company Limited, a company supported by the Forestry Commission to engage in teak plantations; Bernard Kojo Ofori Teak Plantation Ltd, a usufruct title holder, which also owned a large-scale teak company; and ScanFuel, a Norwegian company that was engaged in biofuel cultivation.

These various forms of transformation in the Agogo Traditional Area since the 1980s have had unpredictable local agrarian impacts. The aim of this chapter is twofold. First, it seeks to show the historical trajectories of agrarian investment in the area to fill the knowledge gap surrounding the changing investment patterns in the jatropha space of the Agogo Traditional Area. Second, it seeks to use lessons learned from the changing investment patterns to respond to demands for inclusive sustainable development in the policy space of agri-investments to benefit local migrant/indigenous farmers and nomad Fulani pastoralists.

The chapter focuses on socioeconomic and socio-political issues, mainly tenure, livelihood and conflict in three phases, namely before the arrival of large-scale investments and the cohabitation of indigenous land users and nomad Fulani pastoralist; during large-scale jatropha investment in a volatile environment of existing conflicts between the indigenous land-owning farmers and migrant farmers; and the aftermath of jatropha investment failure and its effects on pastoralists and farmers.

This chapter is relevant for appreciating unpredictable development challenges for investment change, which started with jatropha and changed to maize after the jatropha failure, affecting the volatile environment of the Agogo area and causing the unintended exclusion and alienation of pastoralists and crop farmers.

\section{The study area in context}

The Agogo traditional paramountcy is the allodial land title owner of the Agogo Traditional Area, which includes Asante Akim North District (Figure 4.1). In 2012, Agogo became the capital of Asante Akim North District, which is in the eastern part of Ghana's Ashanti Region, when it was carved out from Asante Akim Central Municipality under L.I. 2057. The total land area of the district is estimated to be nearly 1,217 square kilometres, representing almost 5\% of the total land area of the Asante Region. In terms of adjoining districts, the district is to the 
east of Kwahu East District, to the west of Sekyere East District, to the north of Sekyere Kumawu District and to the south of Asante Akim South District, which was also formerly part of Asante Akim Central Municipality (Ghana Statistical Service, 2010). The district has a population of 71,508, of whom about $67.8 \%$ live in the urban area of Agogo and the remainder in the rural area. The major language spoken in Agogo is Asante Twi, the dialect of the indigenous population (GSS, 2014). The area has a wet semi-equatorial climate with double maxima rainfall occurring from May to July and September to November.

The topography is generally undulating and is interrupted by a stretch of the Akuapim Mampong Range, which serves as a watershed for the numerous rivers and streams in Asante Akim North District. The annual average temperature is 26 degrees Celsius, with the harmattan season, which is associated with drought conditions, occurring between December and March. The entire district lies within the semi-deciduous forest belt, and the major vegetation types are a mix of open forest in highland areas, closed forest on the range and wooded savannah with tree species including wawa, ofram, otie, sapele, sanfina and onyina. To maintain the microclimate of the district, parts of the forests in the district have been made reserves; these are the Bandai Hill reserves at Nyinatokrom, Bebome, Abrewapon and Nyamebekyere. The forest reserves serve as a source of raw materials for the building and construction industries and an income source for the District Assembly and traditional authorities in the form of royalties.

\section{Methodology}

The study was conducted in Asante Akim North District, where the focus of the project was affected communities, namely the district capital and traditional paramountcy (Agogo) and Dukusen, Ananekrom and Nso-Nyameye, where the investment projects were hosted (see Figure 4.1). 


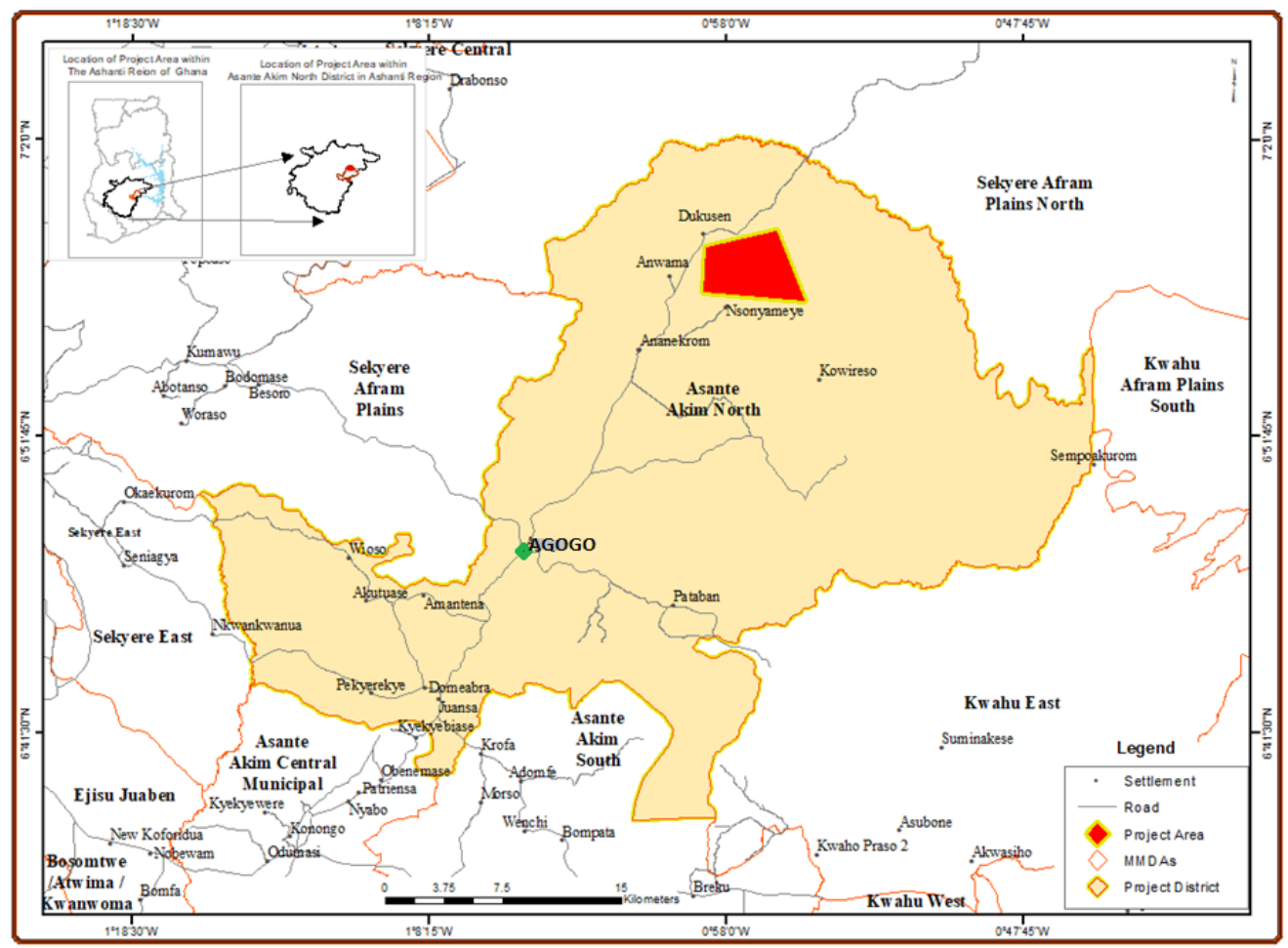

Figure 4.1: Map of Asante Akim North District showing the district capital - Agogo - and the ScanFarm investment area

Source: Author, 2019

The study adopted a qualitative method with a case study approach to explore the interaction between the social phenomenon and the social actors (Yin, 2003). The data for the study were obtained from both secondary and primary sources. Secondary data sources were online institutional documents/publications, library books, resources from the internet, conference papers, theses and journal articles on land issues. For the collection of primary data, the instruments used were interview guides, focus group discussions, telephonic contacts and audio recordings. These instruments were chosen because they allowed the representation of the collective voice and the triangulation of information. 
Table 4.3: Summary of the project in the Agogo area

No

\begin{tabular}{|c|c|c|}
\hline a. & Former land use & Cropland, grazing \\
\hline b. & Ecological zone & Semi-deciduous forest \\
\hline c. & Water management for agriculture & Rain-fed and small-scale irrigation \\
\hline d. & Average temperature & $28^{0} \mathrm{C}$ \\
\hline e. & Soil type & Sandy loam \\
\hline f. & Land acquisition process & Broker \\
\hline g. & Compensation issues & Land owners were compensated \\
\hline h. & Consultations with communities & No \\
\hline i. & Land title type & Lease \\
\hline \multirow[t]{7}{*}{ j. } & Jatropha investment & \\
\hline & - Investor origin & Norway \\
\hline & - Start year & 2007 \\
\hline & - Year of abandonment & 2011 \\
\hline & - Land acquired & 13,000 ha \\
\hline & - Land cultivated & 300 ha \\
\hline & - Number employed in peak season & 150 \\
\hline \multirow[t]{6}{*}{ k. } & Maize investment & \\
\hline & - Investor origin & Norway \\
\hline & - Start year & 2011 \\
\hline & - Land acquired & 13,000 ha \\
\hline & - Land cultivated & 10,500 ha \\
\hline & - Number employed in peak season & 250 \\
\hline
\end{tabular}

In 2014, preliminary surveys led to the identification of a population of about 600 people, mainly migrant farmers, in the study area. To sample from this population, purposive and snowballing sampling techniques were employed to identify 72 individuals connected with or affected by jatropha and maize investment. An interview guide, focus group discussions and participant observations were used to collect the primary data from the respondents; this was complemented by telephonic contacts and audio recordings. Respondents selected for the study in Agogo area met the following set of criteria: must be a local resident (indigenous or migrant) farmer and a local resident who had lived in the study communities for at least four farming 
seasons before the commencement of the jatropha investments. The unit of inquiry comprised indigenous and migrant farmers, Fulani herdsmen, workers (temporary, permanent and any individual who had once worked for ScanFarm before and/or after the investment transformation), landowners or the allodial titleholder (paramount chief - specifically, land management chief and sub-chiefs), investors and government officials.

Table 4.2 Key informants and participants in focus group discussions (FGDs) in the Agogo area

\begin{tabular}{|c|c|c|c|c|}
\hline Agogo & Type of respondents & $\begin{array}{c}\text { FGD } \\
\text { participants }\end{array}$ & $\begin{array}{c}\text { Key informant } \\
\text { interviews }\end{array}$ & Total \\
\hline & $\begin{array}{l}\text { - } \text { ScanFarm (company } \\
\text { - } \text { Forkers/management) } \\
\text { - } \text { Ministry of Food and } \\
\text { Agriculture } \\
\text { - } \text { Traditional land owners } \\
\text { - } \text { District Assembly } \\
\text { members } \\
\text { - } \text { Broker }\end{array}$ & $\begin{array}{l}31 \\
24\end{array}$ & $\begin{array}{l}4 \\
1\end{array}$ & \\
\hline Subtotal & & 55 & 17 & \\
\hline Total & & & & 72 \\
\hline
\end{tabular}

Key informant interviews and FGDs were conducted to understand the concerns and complexities within the study area, which include information on how they were affected by jatropha investments and their abandonment, and investment diversification. Each interview and FGD lasted 30-60 minutes. Primary data were recorded mainly in the form of hand-written notes and audio recordings.

\section{Key informant interviews}

To gain an impression of the study area, face-to-face interviews were conducted with 17 key informants between 2014 and 2018. The key informants were three key informants from ScanFarm, which had been a large-scale investor in jatropha and later maize production; three individual farmers who had been directly affected by the jatropha investment and investment 
diversification into maize; one key official from the Ministry of Food and Agriculture connected to the project at the district level; five traditional landowners and stool land representatives who had taken part in the land negotiation and acquisition process; four Assembly members from the districts affected by the investments; and one broker who had played a role in the acquisition of land and agri-investment projects in the study areas.

\section{Focus group discussions participants}

Three rounds of FGDs were conducted to explore the direct and indirect impact trajectories of jatropha investment and the aftermath of jatropha investment abandonment. The groups participants in the FGDs were 31 company employees who had been engaged in large-scale land acquisition and investments in jatropha and maize, and 24 farmers who had been directly affected by the investment abandonment or diversification. In order to interview respondents directly affected by investment and investment abandonment, farmers and employees were sampled based on these criteria: must be a local resident within the jatropha space of Agogo, and a local resident who had lived in the jatropha space of Agogo for at least four farming seasons before the commencement of the jatropha investments. Each FGD was composed of eight participants to ensure greater control of discussion subjects and allow each participant ample time to share their views and insights (Manoranjitham \& Jocob, 2007). Respondents' views obtained through the FGDs were used to perceive community land use patterns before and during jatropha investment.

Regarding the sampling steps, the first point of contact was made through purposive sampling to the assemblyman of Agogo, who facilitated contact with various community members and the administrative manager of ScanFarm, who revealed the communities that were affected by jatropha investment and investment diversification into maize, namely Dukusen, Ananekrom and Nso-Nyame ye, all of which are within the Agogo Traditional Area.

\section{Results}

\subsection{Before large-scale investment: The land tenure regime and conflicts}

The 1992 constitution of Ghana allows the leasehold of customary or traditional lands, thus embracing the coexistence of traditionalism and government-managed land administrative systems. More than $70 \%$ of the land in Agogo is traditionally managed by the Agogo Traditional Council (TC), while the government manages the remainder as forest reserves and for government projects. The Agogo traditional system is similar to the Kobre traditional system, having a unique hierarchical system with the aim of managing administratively the 
people in the Agogo Traditional Area and the land resources. The clan or family head (abusuapanin) is the lowest form of authority in the hierarchy; above that is the odikro (subchief/caretaker chief), who rules one specific community; and above that is the divisional head, who is in charge of a number of communities and reports to the omanhene (paramount chief), who is the highest in the hierarchy as head of the Agogo TC.

The roles of these leaders at the various levels of authorities include serving as the custodians of land and holding land in trust for the local citizens of Agogo, supporting the development agenda for the communities, and maintaining law and order in their defined territories (Antwi-Bediako, 2018). The odikro manage land in their individual communities (Kugbega, 2018). In addition, the indigenous people, through their clan heads or family heads, have usufruct or ownership rights to land. The TC has a hegemonic power through the paramount chief, who has the overarching power to lease land to migrants, investors or pastoralists, such as Fulani herdsmen.

The indigenous population of Agogo can lease and use land, but migrants do not have the right to lease although they can be granted access rights by the indigenous population or the TC. The odikro also have the power to allocate plots of land up to a maximum size of five hectares; the allocation of plots larger than this is the responsibility of the paramount chief (omanhene). The land tenure regime is such that there are some usufruct families that manage their family lands, and through the heads of such families, stool land may be leased or sublet to other individuals in consultation with the TC, and does not necessarily need the consent of the TC. The traditional land tenure system protects the rights of indigenous people and migrants.

Before 1983, the area was mainly tropical forest that was mostly used to cultivate cocoa. In 1983, bushfires destroyed large tracts of farmland, especially cocoa farms and forest vegetation. This changed the status of Agogo as one of the prominent communities engaged in cocoa production in Ghana. The affected forest was totally transformed into tropical savannah, and this prompted the government, through the Forest Commission, to revegetate the degraded lands through afforestation programmes aimed at reclaiming areas earmarked for forest reserves. At the same time, the landscape transformation attracted Fulani herdsmen - nomadic herders from Niger, Benin and Nigeria (see Figure 4.2). Conditions like the absence of tsetse flies, fresh grassland for grazing with semi-humid conditions, and the availability of streams and rivers as water sources for cattle attracted pastoralists and migrant farmers to the area.

The presence of Fulani herdsmen in Ghana dates back to colonial times. According to the census reports on the Fulani in Ghana, the number of Fulani increased from 100 people in 
1901 to around 302 in 1921. In 1931, the number increased from 302 to 784, made up of 400 males and 384 females, an indication that they had perhaps moved with their wives to Ghana (Tonah, 2005). Their first entry into the Agogo area was through the Afram Plains, because of its sparse population, the low-lying plateau and the presence of water resources, including the Afram River. It was not until the 1980 decentralization efforts that the Afram Plain was divided into four districts, namely Asante Akim North, Sekyere East, Afram Plains and Kwahu. Asante Akim North was further divided into Asante Akim Central Municipality, Asante Akim South District and Asante Akim North District, of which Agogo is the district capital.

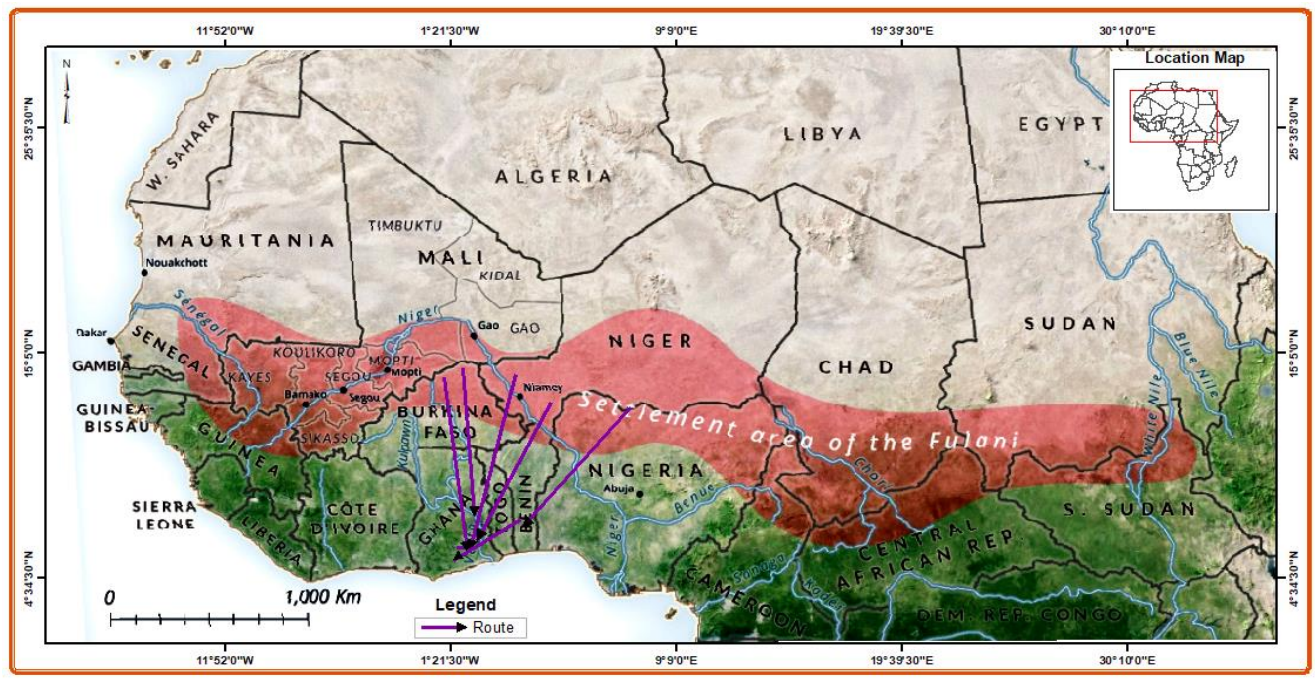

Figure 4.2: Migration of Fulani herdsmen from Fulani settlements in the Sahel region to the Agogo Traditional Area

Source: Adapted from McGregor (2017); Antwi-Bediako (2019).

In the context of the Agogo area, the encroachment by the Fulanis became very intense after the 1983 bushfires. The herdsmen initially operated without formal land leases, and this led to conflicts with the indigenous population and settler farmers over the destruction of crops and other natural resources. The TC decided to resolve these conflicts by allowing formal leases with the Fulani herdsmen. The herdsmen then started negotiations with the traditional landowners, either the paramount chief or usufruct families, but mainly the latter.

The first formal lease agreements between the TC and the Fulani herdsmen, was a lease of 77 ha of land for cattle ranching in 2006 (Kuusana \& Bukari, 2015). Kuusana and Bukari 
(2015) further confirmed that, in a similar manner, other cattle owners acquired land in the area from family heads instead of the traditional paramount chiefs. Whilst lands were leased by Fulani herders, lands adjoining them were leased to smallholder farmers, mainly migrants. Again, several indigenous locals farmed land adjoining that of these pastoralists. These lease arrangement, which created such adjoining land arrangements, exacerbated the conflicts between the Fulani herdsmen and the farmers, because the Fulani's cattle could now easily stray on to farmland and graze on the farmers' food crops. Hence, leasing land to the Fulani did not resolve the conflicts in Agogo. The indiscriminate land leases and the failure of the herdsmen to manage their cattle led to serious and violent conflicts between the herders and farmers.

It is known that during the 2001 to 2013 period, about 50 cases of violent conflicts between farmers and Fulani herdsmen were recorded, with some deaths and injury casualties. (Assemblyman, 2016)

On the other hand, the Fulani herdsmen contend that farmers and other indigenous people encroached upon their land and killed their cattle, despite being given the go-ahead by the landowners to operate in Agogo. The conflict became a national issue as some individuals were killed and properties were destroyed. Agogo gained media coverage as a conflict zone in the Ashanti region. According to a newspaper report:

Since 1990, these Fulani herdsmen have killed about 40 farmers, raped women and girls, and resorted to burning our farms when we confront them after destroying our crops. The Fulani herdsmen have AK 47 assault rifles and deadly guns, so we cannot do anything to defend ourselves. (Gyesi, 2017)

The Newspaper Report-Graphic by Gyesi (2017) claimed that the farmers who had died were the ones who had engaged in violent conflict with the Fulani herdsmen.

\subsection{Impacts of the large-scale land investments}

In the early 2000s, global enthusiasm for biofuel was heightened in the bid to contribute to the fight against climate change, through a reduction in the use of fossil fuel as an energy source. Green energy was thus preferred, and jatropha emerged along with other crops, such as sugar cane and oil palm. Ghana is one of the countries where foreign investors engaged in commercial 
jatropha production for green fuel. This was because of the country's stable political environment, the abundance of land and government commitment to support the production of jatropha.

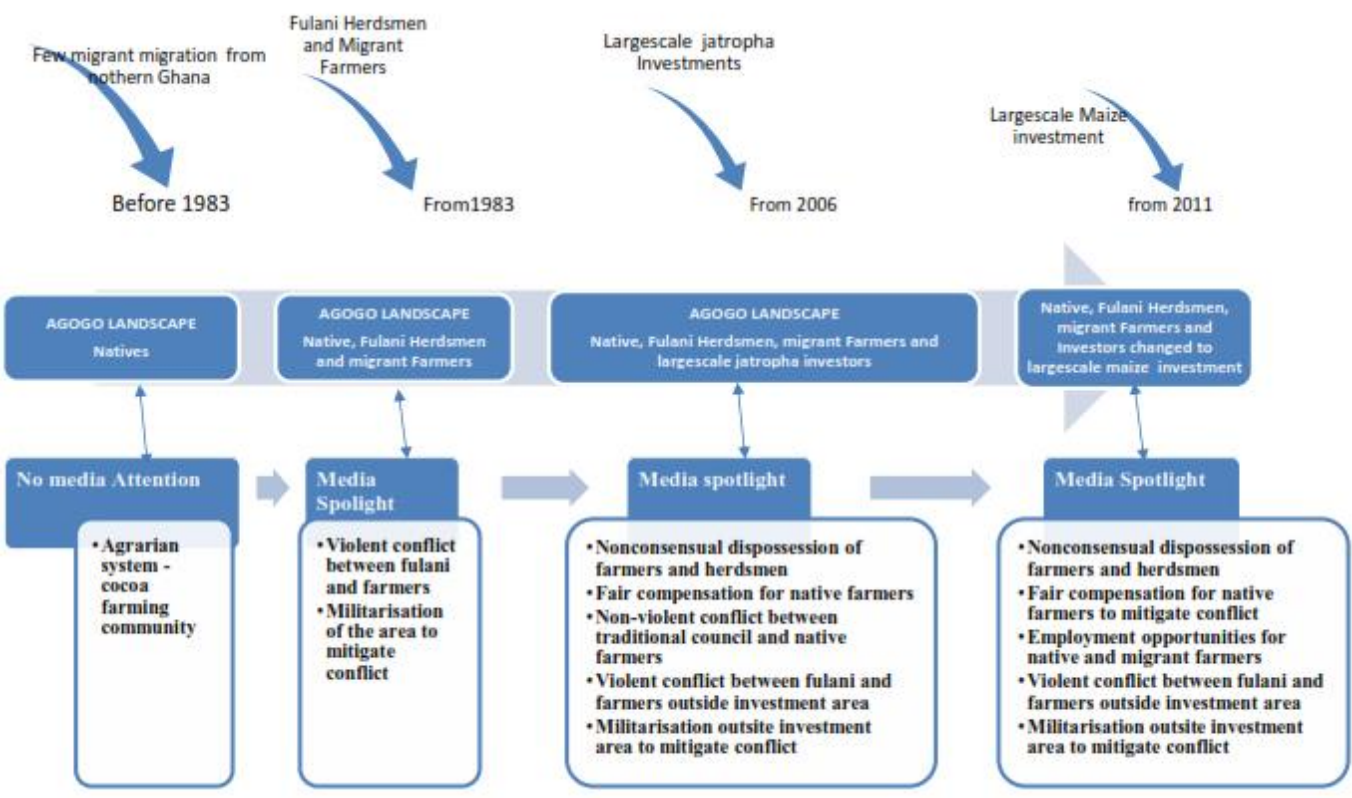

Figure 4.3: Trajectory in the Agogo Traditional Area before and after large-scale investment

Source: Author's own construct, 2019

\subsubsection{Entry of jatropha}

In 2006, a Norwegian enterprise - New Farm Company Limited - established a NorwegianGhanaian partnership to engage in the jatropha investment. The new company - ScanFuel liaised with an elite broker who had told the investor about the huge areas of available land in his hometown in Ghana. The broker was an Accra-based businessman and a member of the Agogo TC. By early 2007, through the support of the broker, the TC welcomed ScanFuel and signed a contract for the lease of about 19,000 ha for a period of 50 years, subject to renewal after 25 years based on a review of the annual ground rent (see Figure 4.3). ScanFuel paid the TC USD 23,000 and the annual ground rent was set at USD 1.00 per 0.4047 ha (= 1 acre) (Kuusana, 2016).

The lease gave the company unrestricted access to any water resources on the acquired land for agricultural purposes and the TC would resolve any emergent land disputes. After 
acquiring the 19,000 ha, ScanFuel proceeded to demarcate the land but was stopped by Bernard Ofori, a usufruct title holder, who also owned a large-scale teak company, Bernard Kojo Ofori Teak Plantation Ltd. Bernard laid claim to 6,000 ha of the land acquired by ScanFuel and proceeded to a formal court of law to have the issue resolved. The formal court ruled in favour of Bernard Ofori and in furtherance to that, the area of leased land was reduced to 13,000 ha (Figure 4.4) through the ceding of 6,000 ha to Bernard Ofori. This resolved the conflict between the two investors. This initial land conflict was an indication that several community members were likely to challenge ScanFuel. The TC resolved the issue with ScanFuel by promising it another tract of land - a promise that was not fulfilled.

In 2007, ScanFuel started cultivating jatropha on its concession near Dukusen (Figure 4.5). A month earlier, the TC had told the odikros (sub-chiefs) of the affected communities to inform their community members about an upcoming meeting with ScanFuel to inform the community about of the company's operation, but few people turned up because of their experience with some investors who were already operating in the area (FGD, Dukusen, 2015). Local communities did not support the jatropha investment partly because of the operational experiences they had had with Miro Company Limited and Bernard Kojo Ofori Teak Plantation. According to the farmers in a focus group discussion in 2015, Miro was engaged by the Forestry Commission of Ghana to participate in its teak planting programme earmarked for Agogo. This partnership led to the acquisition of land allocated to farmers by the TC in 1983. Miro's operations destroyed farmlands and the food crops growing on them along the road linking Agogo to Kumawu. Farmers were therefore disturbed by the arrival of another large-scale investor like ScanFuel. Fears of the likely alienation of local farmers justified the abstention of the community from engaging in dialogue with ScanFuel. 

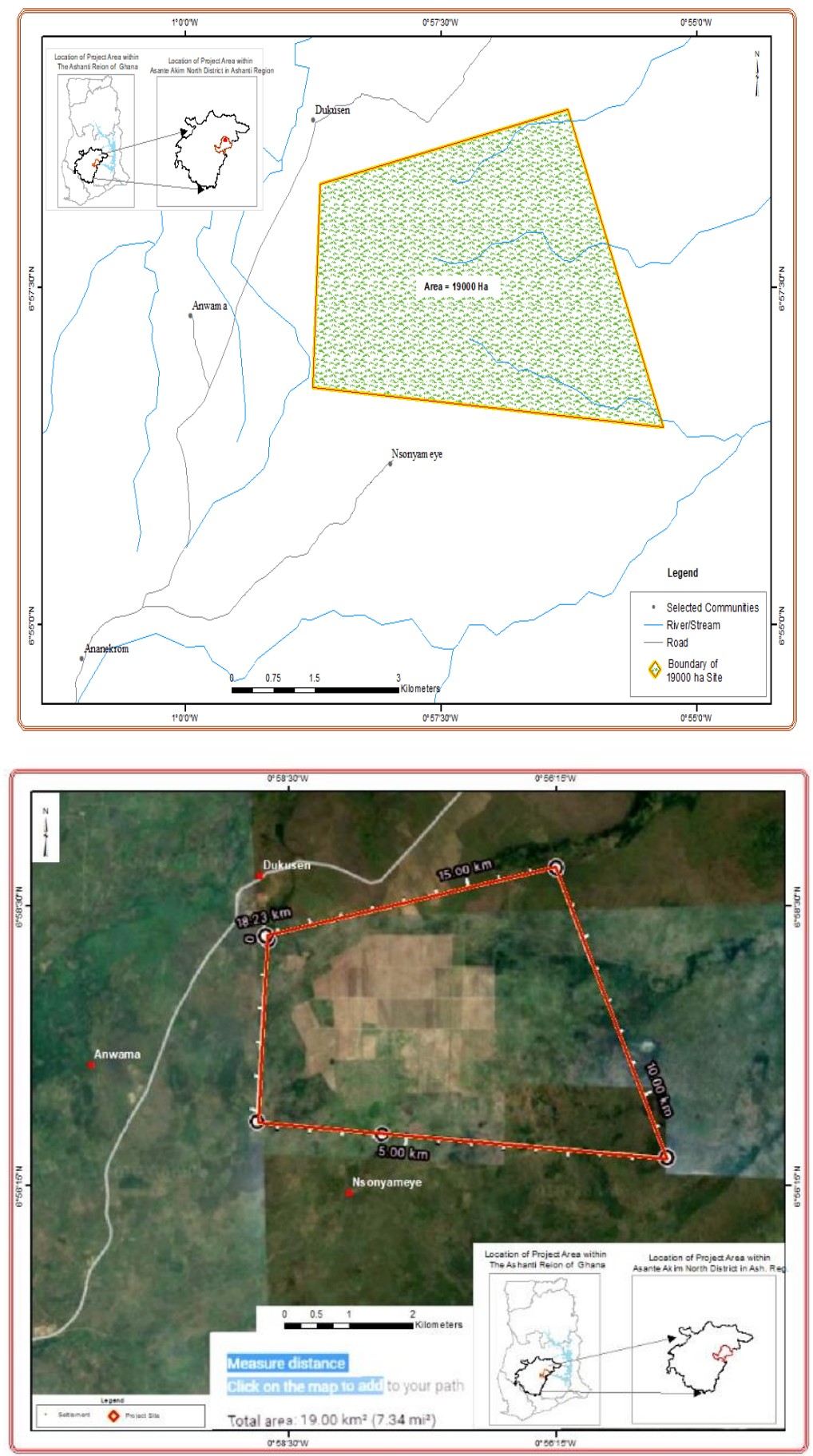

Figure 4.4: Area of land in the Agogo area initially acquired by ScanFuel in 2007 Source: Author, 2019 

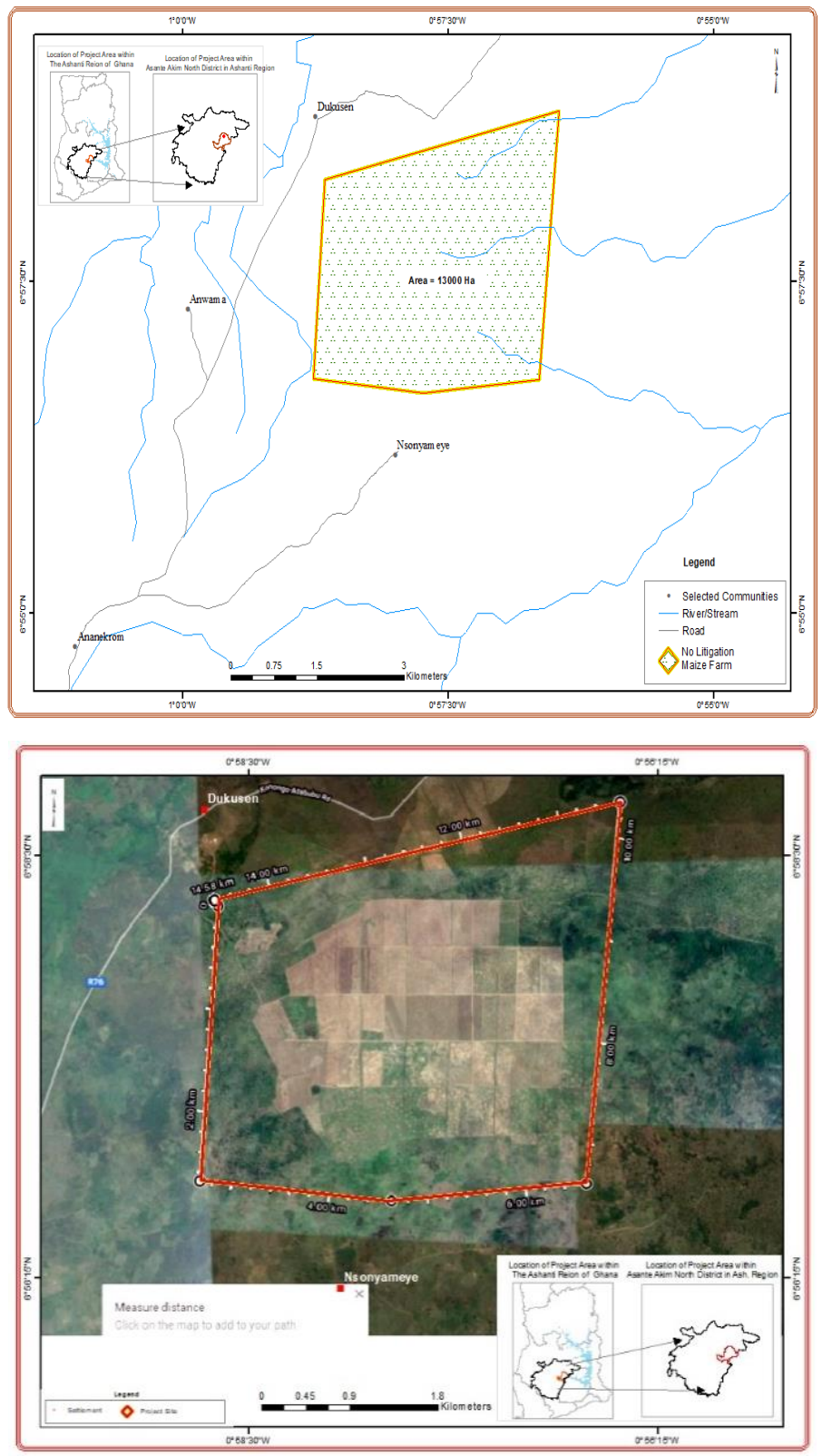

Figure 4.5: Area of land legitimately acquired by ScanFuel after ceding 6,000 ha to Bernard Kojo Ofori Teak Plantation Limited in 2008 Source: Author, 2019 


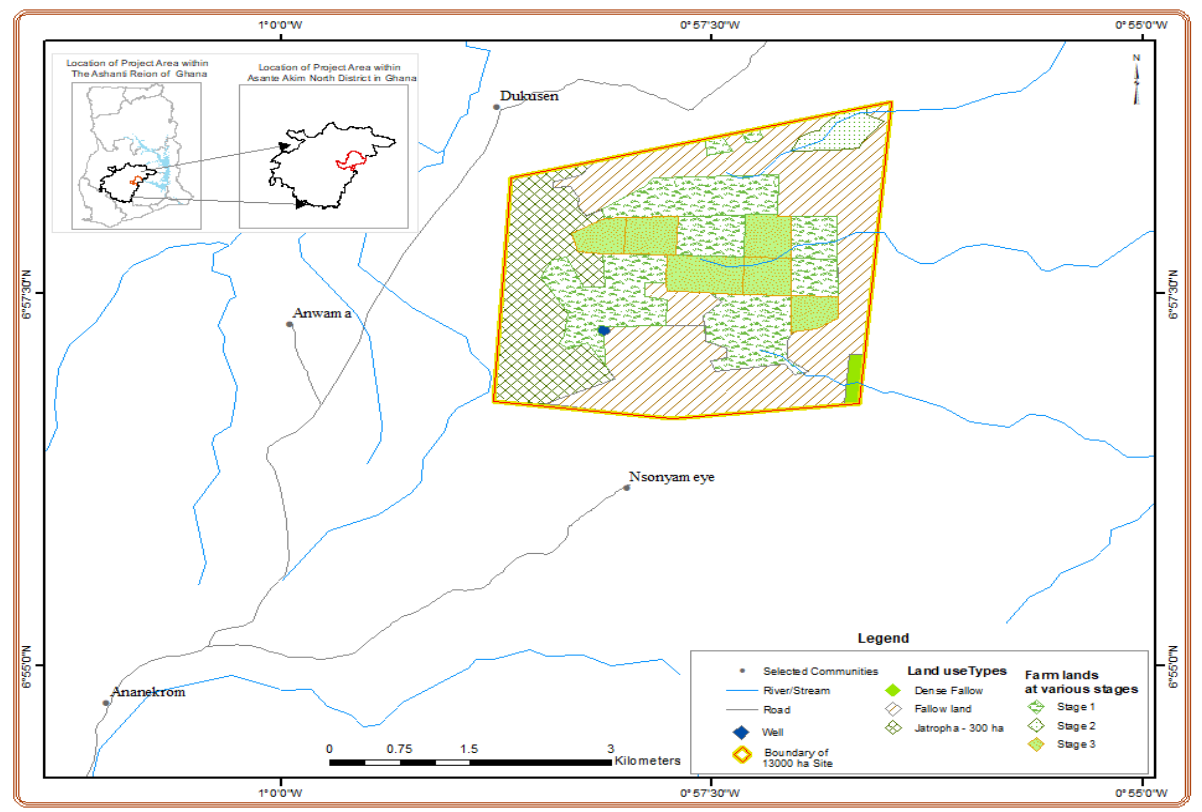

Figure 4.6: Map of the Agogo area showing the land acquired by ScanFarm for jatropha as well as the cultivated and uncultivated areas

Source: Author, 2019

\subsubsection{Jatropha cultivation}

ScanFuel considered its agreement with the traditional paramountcy of Agogo as sufficiently legitimate to start cultivating jatropha. Therefore, disregarding the community's resistance, it started cultivating about 300 ha of jatropha on parts of the fallow land within its concession (see Figure 4.4). The company left crops belonging to farmers untouched, and it employed about 100 farmers for the jatropha operation.

The main issues during the first year of jatropha cultivation were conflicts between ScanFuel and the indigenous farmers, who are mainly usufruct landowners through family heads or clan heads. The farmers and their clan/family heads claimed that they had not been informed about the land transaction and the amount of money received by the TC, while it was they - not the TC - who had the right to lease land to potential investors. The dynamics of conflict thus emerged as conflicts between indigenous farmers and ScanFuel, and between indigenous farmers and the TC. Even though the TC unsuccessfully attempted to mitigate the conflict by getting all parties - the traditional heads, the indigenous farmers and the ScanFuel managers - to come to the table to negotiate and mitigate these conflicts, the contestation continued. Thus, ScanFuel was left to deal with the conflict situation itself. 
This was a breach of the TC's obligation to resolve all conflicts that may arise from the investment. In order to continue its operations, ScanFuel had no choice but to devise a mitigation strategy to resolve the conflict between it and the indigenous farmers who laid claim to the land under cultivation.

We kept asking the traditional council to honour the lease agreement by helping us resolve the conflict, but efforts to get them to sit down with the indigenous farmers came to nothing. The traditional council later tried but the indigenous farmers were very resistant, and so we had to face the full rigor of the pressure mounted on us to resolve the situation.

(Manager of ScanFarm, 2015)

The management of ScanFuel finally managed to get the indigenous farmers, through their family heads and the odikros (sub-chiefs), to negotiate a compensation package. The package, serving as a conflict mitigation strategy, was largely accepted by the indigenous farmers. ScanFuel initially proposed to pay GHS 10 (USD 2.28) per 0.4047 ha (=1 acre) per year to each affected indigenous farmer who claimed to own land acquired by ScanFuel. Even though some indigenous farmers accepted the compensation, a large number did not, as they considered the payment meagre.

I usually get about 42 bags of maize per ha per year, which is about 5,800 cedis [USD $1,000]$, so anything less than that is bad. The company wants a continuous stretch of land but that is not possible until I am well compensated. Different farmers have different interests. (Key informant, Agogo, 2014)

The farmers claimed that the returns from re-leasing the same land to a migrant farmer are better than those from leasing to ScanFuel. By the end of 2007, ScanFuel had increased the annual ground rent to GHS 15 (USD 3.42) per 0.4047 ha.

When we met the company, it said it intended to impose 10 cedis on us - and I did not agree. Finally, we settled on 15 cedis, but we still think it is meagre even though we have accepted payment for now. (Field interview, Odikro' of Nso-Nyame Ye, 2015) 
With compensation set at GHS 15 (USD 3.42) per 0.4047 ha, communities left their land without contestation. Unlike the indigenous farmers, however, the migrant farmers who lost land could not contest the decision of the investors and the TC, and thus did not receive any compensation. Information received from 56 respondents indicates that the amount of land farmers lost due to jatropha cultivation ranged from up to 4 ha (68.5\% of cases) through 5-8 ha $(7.4 \%)$ to more than 40 ha $(7.1 \%)$.

The compensation allowed ScanFuel to cultivate about 300 ha without much interference from indigenous farmers. However, the loss of farmlands meant that both indigenous and migrant farmers had to move to spaces outside the investment area, which led to new conflicts due to potential competition for space between farmers and Fulani herdsmen. For example, at Dukusen in the Agogo area, migrant farmers claimed that the loss of land to the investment had forced them to move to marginal lands that are unproductive and infertile, or to deal with the constant encroachment by Fulani herdsmen on their farms.

We moved to spaces that were not fertile because the investor took over the fertile land we used to farm on. Contrary to the belief that jatropha does well on marginal lands, the land given to the jatropha company by the chief was productive or fertile land, which was being used to cultivate crops such as maize, yam and plantain. (FGD, farmers, 2015)

\subsubsection{After jatropha}

In late 2009, it became clear that jatropha was not a financially viable venture for ScanFuel. First, the alienated farmers did not identify with jatropha because it was a non-food crop conflicting with local food production in the communities. Second, the low yield of jatropha did not give the product market competitiveness. Third, jatropha investments globally had gone bust, prompting ScanFuel to withdraw from the cultivation of jatropha as a biofuel feedstock. Fourth, civil society organizations fuelled the negative perceptions of the 'land grabbing' caused by large-scale jatropha investments, leading to the unfavourable judgement of such investments. Fifth, Ghana discovered oil and the government rapidly lost interest in exploring alternative biofuel opportunities. This led ScanFuel's financiers to stop funding jatropha investment.

Sensing the danger of the failure of jatropha, ScanFuel saw the annual compensation payment to indigenous farmers as a threat to its survival and decided to offer the affected communities GHS 30 (USD 6.84) per 0.4047 ha as a one-time payment. The offer was rejected 
by the indigenous farmers, who told ScanFuel that if it wanted to continue using their land it must also continue to pay the annual payment of GHS 15 (USD 3.42) per 0.4047 ha. ScanFuel decided to stay and switch to a crop more suitable for the land. By the beginning of 2010, ScanFuel had changed the company's name to ScanFarm (see Photo 4.2) and abandoned jatropha cultivation.

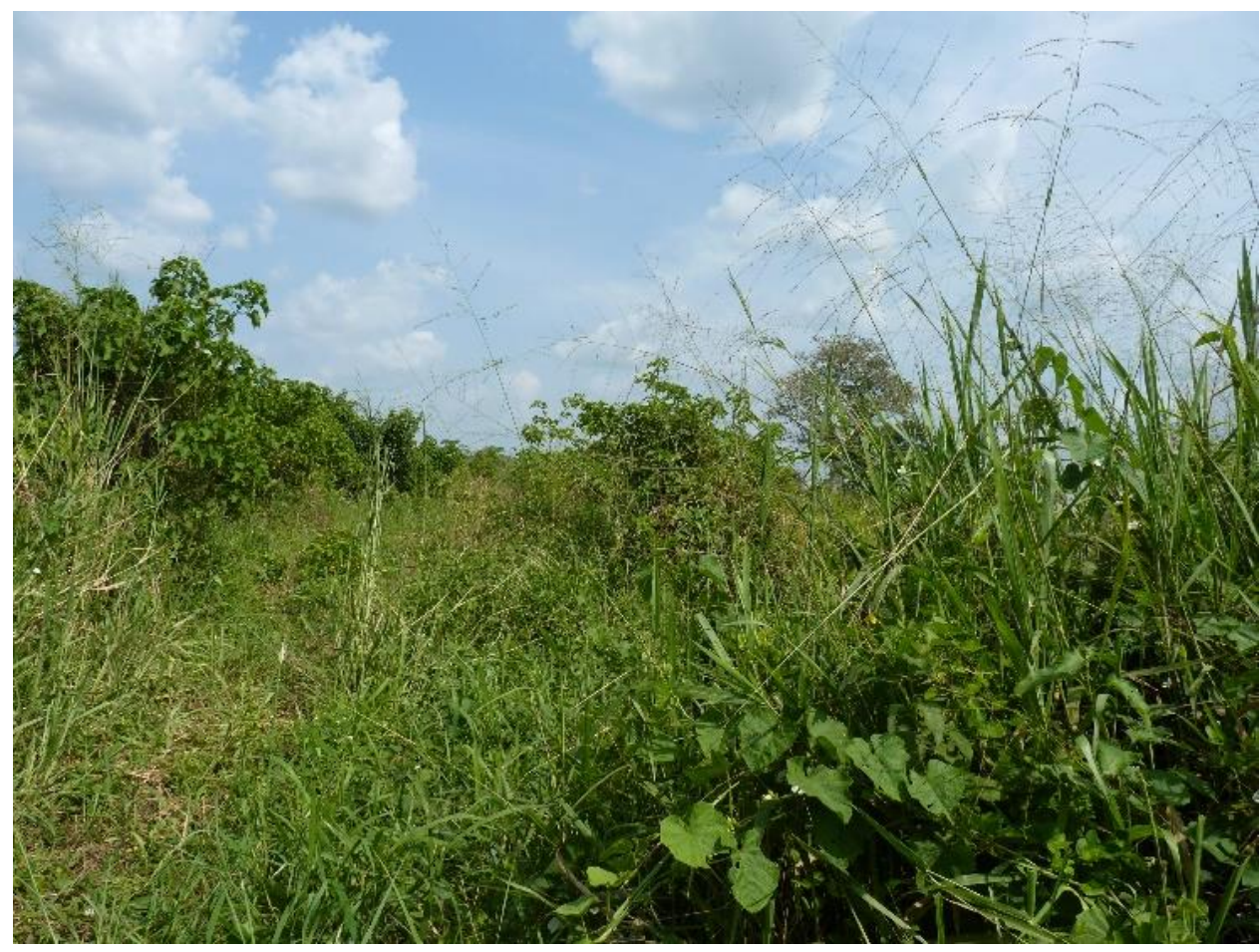

Photo 4.23: Abandoned jatropha on the ScanFarm concession

Source: Field survey, Author, 2011 


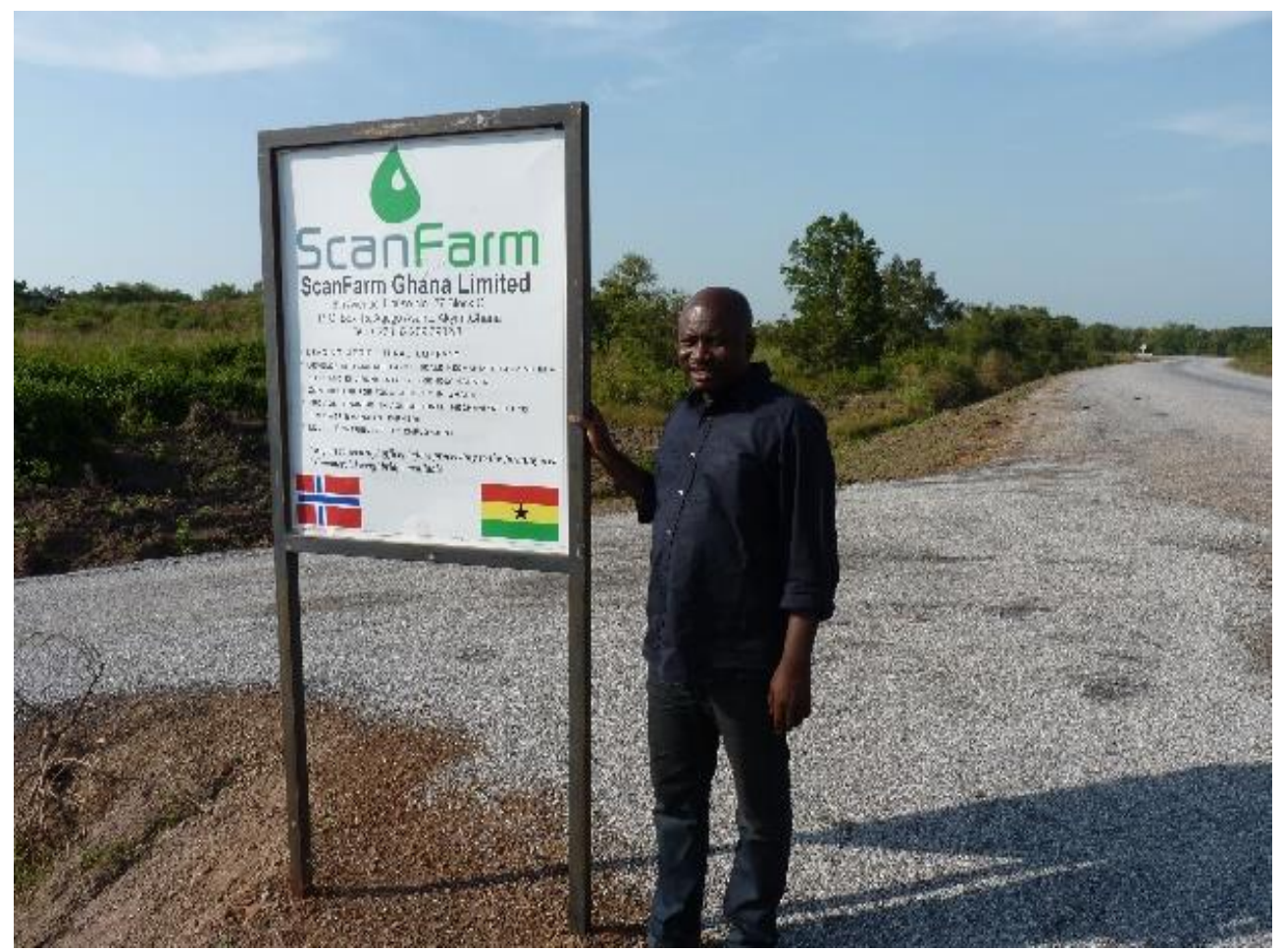

Photo 4.24: A ScanFarm 'Acquired Lands' sign on the Agogo-Etwira Highway

Source: Field survey, Author, 2015.

\subsection{From jatropha to maize}

Having abandoned jatropha, ScanFarm decided that maize, soybean, cassava, sorghum and rice would be suitable crops for the soil type in the jatropha space. Maize was the most preferred because of the available national and international market. Hence, in 2010, the company started a maize pilot project on about 400 ha of the jatropha land. The outcome was successful, and this was gradually expanded to 600 ha, whilst soybeans were cultivated on 20 ha as an experimental crop. Cassava was also cultivated on about 1.2 ha whilst sorghum was planted on 0.8 ha as an experiment.

As the company was convinced that maize would be profitable, it expanded production from 400 to 10,500 ha. By 2011, the Ministry of Food and Agriculture (MoFA) had identified ScanFarm according to a competitive criterion and subsequently adjudged ScanFarm as the best maize producer for Ghana's 2011 Farmers' Day for producing for the World Food Programme (WFP) in 2011 and feeding the domestic market. Since 2011, ScanFarm has engaged in maize production. Other crops are not being considered. 


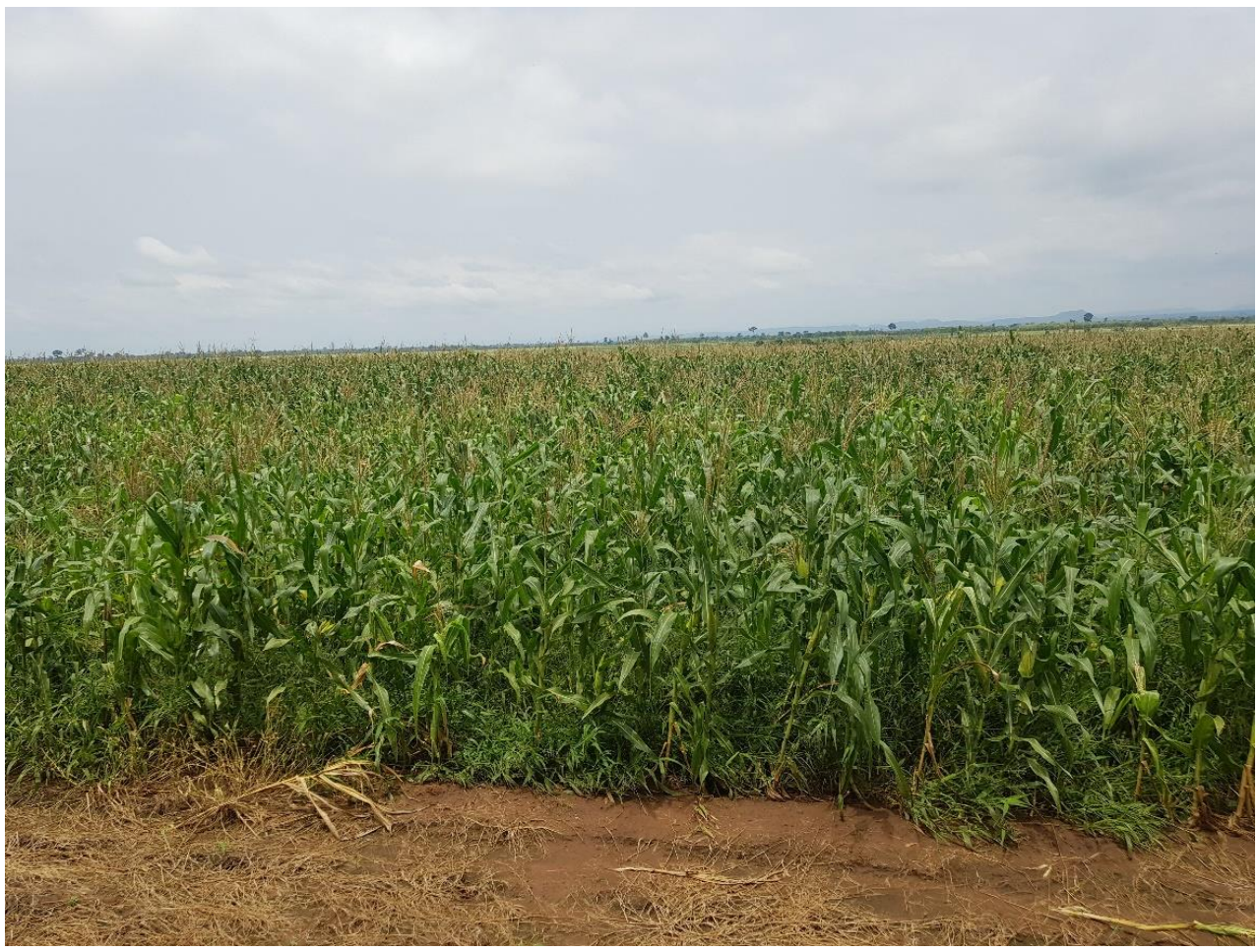

Photo 4.25: ScanFarm maize plantation in the Agogo area

Source: Field survey, Author, 2017

The shift from jatropha to maize, however, induced three major conflicts, namely land conflicts resulting from changing the community tenure arrangement and the non-consensual dispossession of community land users, conflicts between farmers and Fulani herdsmen, and land conflicts resulting from livelihood changes and ecological implications.

\section{Land conflicts}

The traditional tenure arrangement was seriously distorted by the large-scale investment in the Agogo Traditional Area. The tenure arrangement was that both migrants and indigenous people had the right to use land without being dispossessed non-consensually. Before the investment, the dispossession of any farmer had to pass through rigorous traditional court systems to ascertain the reasons for dispossession before alternative land was made available to the dispossessed farmer (FGD, farmers, 2015). According to a ScanFarm manager (2017), 
ScanFarm invested in jatropha in the Agogo Traditional Area without having much information about the tenure arrangement. The community members were not given the opportunity to engage with the TC and ScanFarm to discuss conflict mitigation plans according to traditional rules.

It was well known in Agogo customs that traditional tenure is to the advantage of the land user, but this time - with the arrival of large-scale investment - it did not.

(FGD, farmers, Dukusen, 2016)

The study found that the tenure arrangement was left in the hands of ScanFarm, which had to establish an alternative arrangement to enhance cohabitation with community members affected by dispossession. It did so by instituting the following: a compensation arrangement to reduce community agitation by paying an annual ground rent of GHS 15 (USD 3.42) per 0.4047 ha per year for the deprivation of land, and subsuming community livelihood arrangements into the employment agenda of ScanFarm for both indigenous and migrant farmers by employing 250 temporary casual workers during the harvest season and 50 permanent workers as security and farm labourers.

In practice, the shift from jatropha to maize led to wider dispossession of both migrant and indigenous farmers. During the jatropha investment, jatropha was cultivated on 300 ha and Fulani pastoralists and migrant and indigenous farmers could use the rest of the 12,700 ha for farming and cattle grazing. However, with the emergence of maize cultivation for the World Food Programme and the local market, ScanFarm expanded the cultivation area to 10,500 ha. The expansion was done by non-consensually displacing over 600 migrant farmers and Fulani herdsmen without compensation, unlike indigenous farmers, who qualified for compensation.

There was no community consultation. About 600 people were affected and lost their land. Only the indigenous people were compensated. When people resisted, the company cultivated at night. (Assemblyman, Agogo, 2014)

However, although the indigenous farmers who own land within ScanFarm's 13,000-ha concession were non-consensually dispossessed during the jatropha era, they continue to benefit from annual compensation or ground rent amounting to GHS 15 (USD 3.42) per 0.4047 ha per year. It was affirmed by the manager of ScanFarm (2017) that compensation for indigenous land users and owners is part of company policy to facilitate coexistence with 
communities. This means that the non-consensual dispossession mainly affected migrant farmers and Fulani herdsmen, most of whom dispersed to conflict-prone spaces outside the investment area, where farmer-Fulani conflicts were frequent.

\section{Conflict between farmers and Fulani herders}

During and after jatropha investment and the shift to maize cultivation, conflicts between Fulani herdsmen and farmers took place in and around the ScanFarm concession. The government decided to resolve the conflict by dispatching a team of security officials to drive the Fulani out of Agogo. Some Fulani herdsmen were murdered, but the annual migration of a new wave of Fulani people flooded into the Agogo area. The Agogo TC resorted to mitigating the conflict by leasing lands for ranching to the Fulani herdsmen in the 2000s. The new inclusive strategy by the TC to mitigate conflict induced the further migration of Fulani herdsmen to the Agogo area, as they realized that their predecessors were on good terms with the investors and the community members. These new groups, however, did not enter into formal agreements with the TC; rather, they made informal arrangements with some usufruct families. This complicated the situation, as competition for space for grazing was intensified. Land scarcity was exacerbated as the available land had been leased to ScanFarm in 2007. The increasing number of Fulani arriving from Benin, Niger, northern Ghana and Nigeria made land a very scarce commodity for different resource users. This period therefore saw nonconsensual dispossession of the Fulani herdsmen to spaces outside the ScanFarm investment area; hence the intensification of violent conflict especially between the local communities and the herdsmen outside the large-scale investment spaces of ScanFarm. This was caused by the destruction of crops by the herdsmen's cattle. The study shows that violent conflict exists outside the investment area, mainly between farmers and Fulani herdsmen (Table 4.3; Figure 4.2; Figure 4.5).

The incidence of farmer-Fulani conflicts was minimal in the investment area because of the strong presence of security personnel in the ScanFarm's investment area:

In 2013, herds of cattle strayed into our concession, destroying the maize, which resulted in confrontations between our security staff and the pastoralists. We resolved to kill any stray cattle and bill the owners for every crop destroyed using the court of law. We have not had any incidents since that one. (Field survey, ScanFarm worker, 2018) 
According to participants in an FGD in Dukusen in 2017 and interviews with the officials of ScanFarm in 2016 and 2017, conflict induced by the investment was on the decrease in and around the investment area because ScanFarm had resorted to coercive measures by fencing some parts of its 13,000 ha and deploying a large number of security officers. These strategies to reduce conflicts inside its concession, however, promoted and contributed to the intensification of conflicts outside the concession between the community members (the original farmers) and the Fulani herdsmen due to the competition for land resources between these two main land users.

\section{Non-violent conflict to no conflict between farmers and ScanFarm}

Another strategy employed by ScanFarm to move on from the non-violent stage to a no-conflict stage was the strategic employment of farm supervisors, labourers and security staff from the affected communities. This community-company interface addressed grievances on multiple occasions. Nonetheless, the drive of the investors for employment was not based on professional qualifications; most respondents believe they were employed because they had stakes in the land.

Table 4.3: Summary of conflicts before, during and after jatropha investment in the Agogo area

\begin{tabular}{|c|c|c|c|c|c|}
\hline \multirow[t]{7}{*}{ No } & CLASSIFI & & \multicolumn{3}{|c|}{ DESCRIPTION } \\
\hline & \multirow[t]{6}{*}{ CATION } & \multicolumn{2}{|c|}{ BEFORE INVESTMENT } & DURING & AFTER \\
\hline & & \multirow{5}{*}{$\begin{array}{c}\text { Before the } \\
1983 \text { bushfires }\end{array}$} & \multirow{5}{*}{$\begin{array}{l}\text { After the } \\
\text { bushfires }\end{array}$} & JATROPHA & SWITCH \\
\hline & & & & INVESTMENT & FROM \\
\hline & & & & $2007-11$ & JATROPHA \\
\hline & & & & & TO MAIZE. \\
\hline & & & & & from 2011 \\
\hline \multirow[t]{8}{*}{1} & \multirow{8}{*}{$\begin{array}{l}\text { Tenure } \\
\text { and } \\
\text { land } \\
\text { conflict }\end{array}$} & - Central & \multirow{3}{*}{$\begin{array}{c}\text { - Central control } \\
\text { traditional land } \\
\text { tenure systems }\end{array}$} & - Partial non- & - Non-consensual \\
\hline & & control & & consensual & dispossession of \\
\hline & & traditional & & dispossession of & migrant and \\
\hline & & land tenure & \multirow{2}{*}{$\begin{array}{l}\text { give user rights to } \\
\text { migrant farmers }\end{array}$} & migrant and & indigenous \\
\hline & & systems & & indigenous & farmers \\
\hline & & gave user & Shared cropping & farmers & - Investors pay \\
\hline & & rights to & land tenure & - Investors pay & annual ground \\
\hline & & & arrangement & annual ground & rent to \\
\hline
\end{tabular}




\begin{tabular}{|c|c|c|c|c|}
\hline & $\begin{array}{l}\text { migrant } \\
\text { farmers } \\
\text { - Shared } \\
\text { cropping } \\
\text { land tenure } \\
\text { arrangement } \\
\text { - Population } \\
\text { mainly } \\
\text { indigenous } \\
\text { - No major } \\
\text { conflicts }\end{array}$ & $\begin{array}{l}\text { - Major migration } \\
\text { from the northern } \\
\text { part of Ghana } \\
\text { - } \text { Major migration } \\
\text { from the Sahel } \\
\text { region and other } \\
\text { parts of Nigeria } \\
\text { and Benin of } \\
\text { mainly Fulani } \\
\text { herdsmen } \\
\text { Violent conflict } \\
\text { between farmers } \\
\text { and pastoralists } \\
\text { Militarization as } \\
\text { mitigation } \\
\text { mechanism } \\
\text { Media spotlight } \\
\text { because of violent } \\
\text { conflicts and } \\
\text { militarization }\end{array}$ & $\begin{array}{l}\text { rent to Agogo } \\
\text { TC } \\
\text { - Conflicts outside } \\
\text { the investment } \\
\text { area } \\
\text { - Militarization as } \\
\text { mitigation } \\
\text { mechanism } \\
\text { outside the } \\
\text { investment area } \\
\text { - Media spotlight } \\
\text { because of } \\
\text { violent conflict } \\
\text { outside } \\
\text { investment area } \\
\text { and impacts of } \\
\text { jatropha } \\
\text { investments }\end{array}$ & $\begin{array}{l}\text { indigenous } \\
\text { farmers. } \\
\text { - No Fulani } \\
\text { herdsmen in } \\
\text { investment area } \\
\text { - All farmers } \\
\text { secure } \\
\text { alternative lands } \\
\text { for crop farming } \\
\text { outside } \\
\text { investment } \\
\text { concession } \\
\text { - Conflicts } \\
\text { outside the } \\
\text { investment area } \\
\text { - Non-violent } \\
\text { conflict } \\
\text { between } \\
\text { indigenous } \\
\text { people and TC } \\
\text { - Militarization } \\
\text { as mitigation } \\
\text { mechanism } \\
\text { outside the } \\
\text { investment area }\end{array}$ \\
\hline $\begin{array}{l}2 \text { Livelihood } \\
\text { conflicts }\end{array}$ & $\begin{array}{ll}\text { - } & \text { Main } \\
\text { livelihood } \\
\text { was farming } \\
\text { - Cash-crop } \\
\text { farm } \\
\text { produce, } \\
\text { mainly } \\
\text { cocoa. }\end{array}$ & $\begin{array}{l}\text { Main livelihood } \\
\text { crop farming and } \\
\text { pastoralism with } \\
\text { periodic violent } \\
\text { conflicts }\end{array}$ & $\begin{array}{l}\text { - Employment of } \\
100 \text { farmers by } \\
\text { jatropha investor } \\
\text { but periodic } \\
\text { conflicts between } \\
\text { pastoralists and } \\
\text { farmers outside }\end{array}$ & $\begin{array}{l}\text { - Employment } \\
\text { of } 250 \\
\text { farmers by } \\
\text { maize } \\
\text { investor, but } \\
\text { periodic } \\
\text { conflicts } \\
\text { between }\end{array}$ \\
\hline
\end{tabular}




\begin{tabular}{|c|c|c|c|c|c|}
\hline & & $\begin{array}{l}\text { Staple food } \\
\text { mainly } \\
\text { maize, } \\
\text { cassava and } \\
\text { plantain. }\end{array}$ & & $\begin{array}{l}\text { the investment } \\
\text { area }\end{array}$ & $\begin{array}{l}\text { pastoralists } \\
\text { and farmers } \\
\text { outside the } \\
\text { investment } \\
\text { area }\end{array}$ \\
\hline 3 & $\begin{array}{l}\text { Ecological } \\
\text { Degradation }\end{array}$ & $\begin{array}{l}\text { - National } \\
\text { Forest } \\
\text { Reserves. } \\
\text { - Traditional } \\
\text { forest. }\end{array}$ & $\begin{array}{l}\text { - Grassland with } \\
\text { patches of forest } \\
\text { - National Forest } \\
\text { Plantation } \\
\text { programme }\end{array}$ & $\begin{array}{l}\text { - Depletion of } \\
\text { green vegetation } \\
\text { through } 300 \text { ha of } \\
\text { jatropha } \\
\text { cultivation and } \\
\text { alienation of } \\
\text { farmers and } \\
\text { pastoralists } \\
\text { - National Forest } \\
\text { Plantation } \\
\text { programmes } \\
\text { outside } \\
\text { investment area } \\
\text { limited space for } \\
\text { farmers and } \\
\text { pastoralists and } \\
\text { creation of } \\
\text { periodic conflicts }\end{array}$ & $\begin{array}{l}\text { - Depletion of } \\
\text { green } \\
\text { vegetation } \\
\text { through } \\
\text { 10,500 ha of } \\
\text { maize } \\
\text { cultivation } \\
\text { and alienation } \\
\text { of } 600 \\
\text { farmers and } \\
\text { pastoralists } \\
\text { - National } \\
\text { Forest } \\
\text { Plantation } \\
\text { programmes } \\
\text { outside } \\
\text { investment } \\
\text { area limiting } \\
\text { space for } \\
\text { farmers and } \\
\text { pastoralists } \\
\text { and creating } \\
\text { periodic } \\
\text { conflicts. }\end{array}$ \\
\hline
\end{tabular}

Source: Author, 2019

\section{Discussion}

This case shows that the dynamics of land tenure in the Agogo Traditional Area changed after the 1983 bushfires in major forest reserves in the area, which led to conflicts and the 
diversification of crops, which in turn had impacts on land tenure, livelihoods and the ecological landscape. This catalysed a land rush by Fulani herdsmen and indigenous and migrant farmers to spaces under fallow and to forest reserves at the local and regional levels, as well as by largescale investors to such land spaces during the globalized search for alternative fuels (Headley \& Fan, 2008; Piesse \& Thirtle, 2009). This was to be expected, because Fulani herders traditionally take advantage of post-harvest opportunities by moving from the north to the south so that their cattle can feed on the crop remnants, or to escape from environmental pressures in the north (McGregor, 2017). More especially, the bushfire disaster in the Agogo area served as favourable conditions for two major land users - farmers and Fulani herdsmen - whose coexistence, according to Colchester (2011), has often been characterized by unresolved violent conflicts. Thus, conflicts leading to the death of pastoralists or farmers were an expected phenomenon.

The case presents factors that contribute to land scarcity and the non-consensual dispossession of local land users (Anseeuw et al., 2012) due to the entry of large-scale investments. The failure of jatropha and crop change after jatropha have created various types of conflicts, including conflicts induced by tenure arrangement issues incited by the nonconsensual dispossession of farmers and Fulani pastoralists; livelihood conflicts induced by competition for space between farmers and Fulani pastoralists; ecological alterations to the investment environment, inciting the migration of affected farmers and pastoralists to spaces that are not favourable for the coexistence of farmers and pastoralists; conflicts induced by the exclusion of farmers and pastoralists from consultations on benefit sharing arrangements between farmers and the TC; and conflicts induced by the marginalization and exclusion of farmers and pastoralists from dialogues with the TC and investors about alternative lands and livelihoods.

\subsection{Land tenure, livelihood and conflicts}

Land tenure and livelihood considerations in terms of land rights, labour conditions and food security are considered important for local land users in any large-scale investment initiative (Hunsberger et al., 2014). When inequities result in the exclusion and marginalization of farmers from tenure and livelihood considerations, conflicts are inevitable (ibid). The study found that migrant farmers on the 5260 ha (13,000 acres) of jatropha land in 2007 were excluded from dialogues with investors and were non-consensually dispossessed and subsequently lost their rights to use the land. Hence, it is possible to suggest that the tenure issues resulting in the exclusion and marginalization of migrant farmers from consultations on benefit sharing 122 | P a g e 
arrangements and land rights issues hampered the peaceful coexistence between farmers and ScanFuel (now ScanFarm) Limited during the jatropha investment regime.

After the investment change, ScanFarm leaned more on the tenure dynamics of the Agogo Traditional Area and strategized by re-engaging with farmers, especially the original land users, and entering into new negotiations and compensation arrangements to resolve conflicts and support farmers' livelihoods. We can gain a substantive understanding by observing the way the traditional institution disconnected itself from all further mitigation measures after leasing the land to ScanFarm. Such disconnection also indicates the loss of control by the TC over communities' tenure issues in the volatile environment of the Agogo area. The TC disconnect in the real crisis is rooted in escaping from the costs involved in mitigating conflicts through paying compensation. As noted by Ubink and Quan (2008), some chiefs administered lands as though they were their private property, and they benefited unilaterally from the proceeds whilst the community members were negatively affected. The marginalization and exclusion of farmers in the affected communities was confirmed by Acheampong and Campion (2014) and have resulted in land conflict induced by large-scale land acquisition.

The exclusion and marginalization of migrant farmers, pastoralists and indigenous farmers confirms that the TC failed to settle the land tenure disputes. Hence, the persistent pressure on the investor forced the investor to put in place compensation arrangements to meet the needs of the affected indigenous farmers without recourse for migrant farmers and pastoralists. ScanFarm went through the renegotiations and compensated the indigenous farmers to mitigate major potential conflicts with indigenous landowners. It is therefore important for the TC to take another look at re-institutionalizing the traditional systems to make decision making on livelihood arrangement as inclusive as possible.

It is clear from the findings that ScanFarm's investment in jatropha in 2007 and change to maize in 2011 accelerated the dispossession of pastoralists. However, the presence of the large-scale investment could not influence new negotiations and tenure arrangements with local farmers and Fulani pastoralists outside the investment area; thus, violent conflicts continued outside the investment area and were left for the government to deal with. Therefore, I argue that conflict between local farmers and Fulani pastoralists will be unavoidable as long as there is weak control of tenure arrangements by the TC, but it can be resolved by supporting inclusive coping mechanisms on a case-by-case basis backed by policy direction and strong traditional institutions. 


\subsection{Changing landscape and conflicts}

Prior to the investment, the indigenous people of Agogo depended on the forest landscape and resources and green vegetation for their livelihoods, and used the land to produce cocoa and a wide range of food crops, including tubers, maize, legumes and vegetables. Although corporate investors have been blamed for the destruction of local ecological environments in order to meet their needs (profit) to the detriment of affected communities (Achten et al., 2010; Openshaw, 2000), Agogo faced various challenges: it was under siege from large-scale investment, pastoralism and small-scale migrant farmers, all of which contributed enormously to the deterioration of green resources, preventing the local ecological environment from rejuvenating. Thus, the destruction of the green resource cannot be attributed only to large-scale investment. However, the planting of jatropha and maize led to the transformation of over 10,000 ha of secondary forest and forced farmers to move to other areas, where they used new lands - mainly fertile, green vegetated lands - for farming purposes. As rural communities depend greatly on ecological services for their livelihoods (Watson et al., 2006), preventing local land users from using ecological environments can result in diversified conflicts.

\section{Conclusion}

The chapter showed that after the jatropha investment failure, crop diversification from jatropha into maize changed the dynamic of the volatile environment. The chapter presented a unique case of investment change from jatropha to maize investment, and the effects on local development and the conflict dynamics for farmers and pastoralists that are relevant for appreciating the unpredictable development challenges brought about by investment change. Whereas this chapter concentrated on understanding conflicts as diversified due the effect of large-scale investment changes from jatropha to maize, the events of 1983 depict the case study area as one of volatility and conflicts for pastoralists and local farmers, even before the investments. However, the investment change brought about new diversities of conflicts between pastoralists and farmers, and a volatile environment marked by new fragmented and periodic conflicts.

The chapter shows the change in land tenure systems in the Agogo area since the 1983 bushfires and the underlying reasons for the migration of farmers from northern Ghana, Fulani herdsmen from the Sahel region of West Africa and large-scale investors from abroad. The Agogo Traditional Area thus became a potential development hub and a conflict zone. Largescale investors contested spaces with farmers and pastoralists, and non-consensually 
dispossessed both farmers and pastoralists. Indigenous farmers who were non-consensually dispossessed were compensated, unlike the migrant farmers and pastoralists. However, the roughly 250 casual workers who were employed were mainly migrant farmers.

Regarding conflicts due to investment diversification, conflicts were mainly influenced by land tenure issues, limited space for local land users and competition for space for livelihoods, and ecological impacts outside the investment area. Hence, farmer-Fulani-investor conflict was prevalent because of the competing claims for land for either grazing or farming purposes. Notwithstanding, if investors decide to expand there, the tendency to exacerbate future conflicts because of competition and the increasing need for space for grazing and farming, and various forms of land litigation may re-emerge. Hence, whilst actions are needed to ensure co-existence amongst these actors, attention should be geared towards land use planning for the Agogo Traditional Area, the strengthening of tenure practices that favour all actors, and the possible formation of anti-Fulani and anti-large-scale investment vigilante groups.

\section{References}

Acheampong, E. and Campion, B.B., 2014. The effects of biofuel feedstock production on farmer's livelihoods in Ghana. The case of Jatropha curcas. Sustainability, 6(7), 45874607. http://dx.doi.org/10.3390/su6074587.

Achten, W.M.; Maes, W.H.; Aerts, R.; Verchot, L.V.; Trabucco, A.; Mathijs, E.; Singh, V.P.; and Muys, B. (2010). Jatropha: From global hype to local opportunity. Journal of Arid Environments, 74, 164-165.

Amissah, L., Kyereh, B., \& Agyeman, V. K. (2010). Wildfire incidence and management in the forest transition zone of Ghana: farmers' perspectives. Ghana Journal of Forestry, 26(1).

Ampadu-Agyei, O. (1988). Bushfires and management policies in Ghana. Environmentalist, $8(3), 221-228$.

Anseeuw, W., Wily, L. A., Cotula, L., \& Taylor, M. (2012). Land rights and the rush for land: Findings of the global commercial. ILC: Rome, Italy.

Antwi-Bediako, R. (2018). Chiefs and nexus of challenges in land deals: An insight into blame perspectives, exonerating chiefs during and after Jatropha investment in Ghana. Cogent Social Sciences, 4(1), 1456795. https://doi.org/10.1080/23311886.2018.1456795 
Colchester, M. 2011. Palm oil and indigenous peoples in South East Asia. FPP contribution to ILC Collaborative Research Project on Commercial Pressures on Land, Rome.

Government of Ghana, 2014. Ministry of Local Government and Rural Development, Asante Akim Central Municipal Assembly Medium Term Development Plan 2014-2017. https://new-

ndpcstatic1.s3.amazonaws.com/CACHES/PUBLICATIONS/2016/04/04/AR_AsanteAkim+Central_2014-2017+MMTDP.pdf

Ghana Statistical Service (2010). 2010 Population and Housing Census, District Analytical Report for Asante Akim North District, Ashanti region, Ghana

Gyesi Zadok K. 2017. We feel neglected and abandoned-Agogo residents cry over Fulani herdsmen activities. https://www.graphic.com.gh/news/general-news/we-feelneglected-and-abandoned-agogoresidents-cry-over-fulani-herdsmen-activities.html

Hawthorne, W. D. (1994). Fire damage and forest regeneration in Ghana: forestry inventory and management project of the Ghana Forestry Department (No. 4). Natural Resources and Environment Department, Overseas Development Administration (ODA).

Headley, D. and S. Fan. 2008. Anatomy of a Crisis. The Causes and Consequences of Surging Food Prices. IFPRI. Washington D.C.

Hunsberger, C., Bolwig, S., Corbera, E., and Creutzig, F. 2014 Livelihood impacts of biofuel crop production: Implications for governance. Geoforum, 54, 248-260

Kaledzi, I. 2016. Farmers, nomadic herdsmen clash in Ghana. https://www.dw.com/en/farmersnomadic-herdsmen-clash-in-ghana/a-19028767

Kugbega, S. (2018). Are Indigenous Farmers' Investments Under Siege? Implications of farmer-herder conflicts and threats to customary land tenure on indigenous farmers' agricultural investment decisions in Agogo, Ghana.

Kuusana, D.K. and Bukari, K.N. (2015). Land conflicts between smallholders and Fulani pastoralists in Ghana: Evidence from the Asante Akim North District (AAND), Journal of Rural Studies, 42 (2015), 52-62.

Manoranjitham, S. \&Jacob, S.K., (2007). Focus group discussion. Journal of the Nursing Association of India, 98(6), 125-127

McGregor, A. (2017). The Fulani Crisis: Communal Violence and Radicalization in the Sahel. CTC Sentinel, 10(2), 34-40. 
Nhyira FM, 2017. Children of victims of farmer-herdsmen conflict in Agogo receive support. https://www.myjoyonline.com/news/2017/october-18th/children-of-victims-ofherdsmen-farmer-herdsmen-conflict-in-agogo-receive-support.php

Nsiah-Gyabaah, K. (1996). 'Bush fires in Ghana. IFFN Country Reports, No 15, pp 1-10.

Olaniyan, A., Francis, M., \& Okeke-Uzodike, U. (2015). The Cattle are 'Ghanaians' but the Herders are Strangers: Farmer-Herder Conflicts, Expulsion Policy, and Pastoralist Question in Agogo, Ghana. African Studies Quarterly, 15(2), 53.

Openshaw, K. (2000). A review of Jatropha curcas: An oil plant of unfulfilled promise. Biomass and Bioenergy, 19, 1-15

Piesse, J. and C. Thirtle. 2009. Agricultural R\&D, technology and productivity. Philosophical Transactions of the Royal Society: Biological Sciences, Vol. 365.

Tonah, S. (2005). Fulani in Ghana: Migration history, integration and resistance. Research and Publication Unit, Department of Sociology, University of Ghana.

Ubink, J. and Quan, J. (2008). 'How to Combine Tradition and Modernity? Regulating Customary Land Management in Ghana'. Land Use Policy, 25 (2), 198-213

Yin, R.K., 2003, Case study research: Design and methods, Applied social research methods series, Sage, Thousand Oaks, CA, Inc. 


\title{
CHAPTER 5
}

\author{
The case of Lolito:
}

From jatropha to rice 


\begin{abstract}
In Ghana, agri-investments and the aftermath of their failures have led to new investment dynamics, whereby lands are increasingly being re-occupied by new types of agricultural monoculture. This chapter explore the trajectory of monoculture investments from jatropha to rice cultivation, and how monoculture investments have enclosed jatropha spaces and exposed the vulnerability of common pool resource users. The findings suggest that any action to change an agrarian rural landscape by promoting the enclosure of large-scale agriculture monoculture must consider the entire environment and the socioeconomic complexities. Given the importance of land to both rural and commercial land users, it is imperative to develop clear guidelines, especially ones that promote inclusive sustainable development.
\end{abstract}

Keywords: Jatropha, rice, enclosure, large-scale, monoculture, transformation, broker. 


\section{Introduction}

In Ghana, jatropha investment and the aftermath of jatropha investment failure have led to a new form of investment dynamics whereby jatropha lands are increasingly being re-occupied by new types of large-scale agricultural enclosures for food crops. South Tongu District in the Volta region of Ghana has been the target of a number of large-scale agri-investments and new enclosures, known to be a rapidly growing and booming district agri-business. In recent years, the district has attracted intensive agri-investors like Biofuel Africa Limited from Norway, which was involved in jatropha investment from 2008 to 2010; Global Agricultural Development Company (GADCO), an organization made up of companies from the United Kingdom, Nigeria and India that has been cultivating rice in the district since 2011; and Brazil Agro-Business, which is also engaged in large-scale rice cultivation in the district. These are just a few examples of foreign agricultural investments in different parts of Ghana that are taking advantage of the country's neoliberal political environment.

South Tongu District attracts investments because of the low-lying coastal savanna zone (max. $75 \mathrm{~m}$ above sea level), available water resources, attractive policy conditions on commercial agriculture and climatic conditions suitable for agriculture. The district covers 644 $\mathrm{km}^{2}$ in the southern part of the Lower Volta Basin in the Volta region of Ghana (Figure 5.1) and lies between latitudes $6^{\circ} 10^{\prime}$ and $5^{\circ} 45^{\prime}$ north and longitudes $30^{\circ} 30^{\prime}$ and $0^{\circ} 45^{\prime}$ east. It has a population of 87,950 people, accounting for about $4.1 \%$ of the total population of the entire region (Ghana Statistical Service-GSS, 2014). With an annual growth rate of $3.6 \%$, the district population is likely to exceed 140,000 in 2019. 


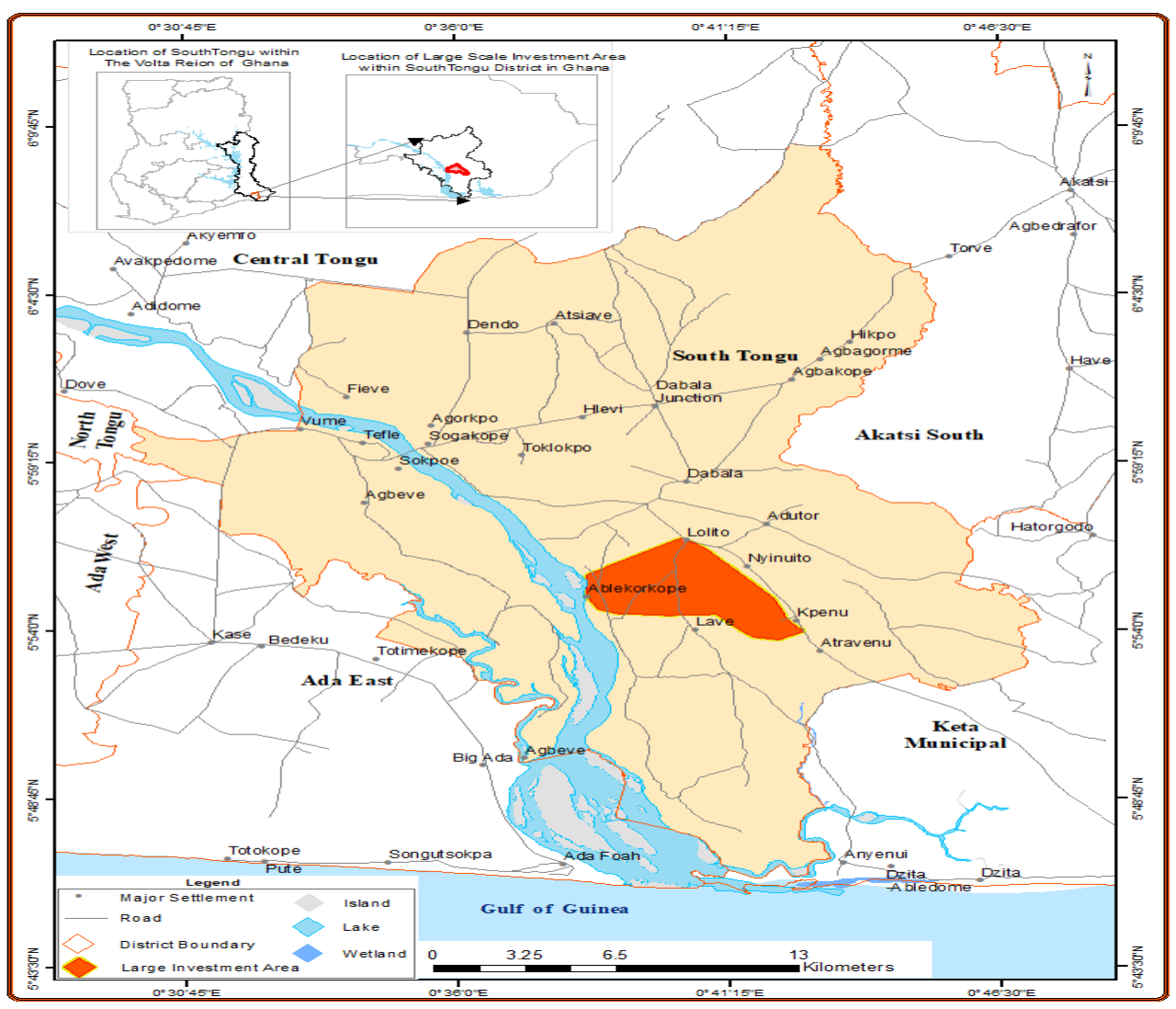

Figure 5.10: Map of South Tongu District showing the jatropha investment area.

Source: Author, 2019

Approximately $74 \%$ of the people are literate (one of the highest rates amongst the districts in Ghana), with over $65 \%$ of such people living in urbanized communities, such as Sogakope and Dabala (Ghana Statistical Service, 2014). Illiterate people are predominantly found in the rural agrarian communities, and they depend on land, water and other natural resources as their main sources of livelihood. There is a very high rate of emigration of literate people to other urban centres, such as the regional capital (Ho) and Accra, the national capital.

The district is endowed with large clay deposits, specifically in the jatropha and rice investment sites Lolito, Vume and Sokpoe, which according to geologists will last for over 100 years if mined commercially in a sustainable manner (GSS, 2014; South Tongu District Assembly, 2014). These communities also have a large volume of mineral deposits that can be developed into paints and other chemical products. There are also large deposits of sand, gravel and salt. In the southern part there are areas of swamps and mangroves, and in the northern part 
there is savannah woodland (ibid). The main rainy season starts in late March or early April and continues to July, with the highest rainfall (an average of $195 \mathrm{~mm}$ per annum) in MayJune. These features make the district suitable for the cultivation of such crops as sugar cane, rice, okra and pepper, as well as for raising livestock.

More than half of the population use the resources on the land and in the rivers for their livelihoods. Crop farming is predominant but cattle rearing is also common; in fact, according to the Ghana Statistical Service (2014), the district ranks second in terms of heads of cattle. The Volta River provides fishing in the form of capture fisheries and the culture of tilapia, shrimp and catfish. These are usually harvested and sold to travellers along the Trans ECOWAS Highway linking Accra to Lomé (the capital of Togo), which passes through Sogakope (the district capital of South Tongu) and other nearby urban centres, such as Keta and Aflao, in the Volta region.

With more than half the population in the district depending on land and water resources, the large-scale investments, which have resulted in landscape changes in the district, have given rise to concerns about the various socio-political, socioeconomic and environmental effects of these investments and thus reason to investigate the dynamics of these effects. As shown in Table 6.1, Biofuel Africa Limited invested in jatropha in South Tongu District in 2006 and abandoned the investment in 2010. Another investor, a Brazilian company (Brazil AgroBusiness Group Limited; BABGL) took over in 2011 and cultivated rice on the same land.

The investment transitions led to diverse regimes of intended and unintended realities that need to be understood, appreciated and documented to inform future policy options in relation to changing investments. Therefore, this chapter seeks to ascertain broader changes resulting from these changing investments and to answer questions concerning the effects of open communal land without investment, when there was jatropha investment and when there was rice investment in South Tongu's agricultural land. The chapter adopts a descriptive approach for the purposes of understanding the development outcomes and realities from the community's perspective because they are users of the common pool resources within the landscape.

\section{Methodology}

This case study investigated the transformations of landscape and the socioeconomic situation of investment areas mainly in Lolito, as well as in other communities affected by the jatropha and rice project, namely Nyinato, Kpenu, Ablekorkope and Atravenu (Figures 5.1 
Figure 5.11).

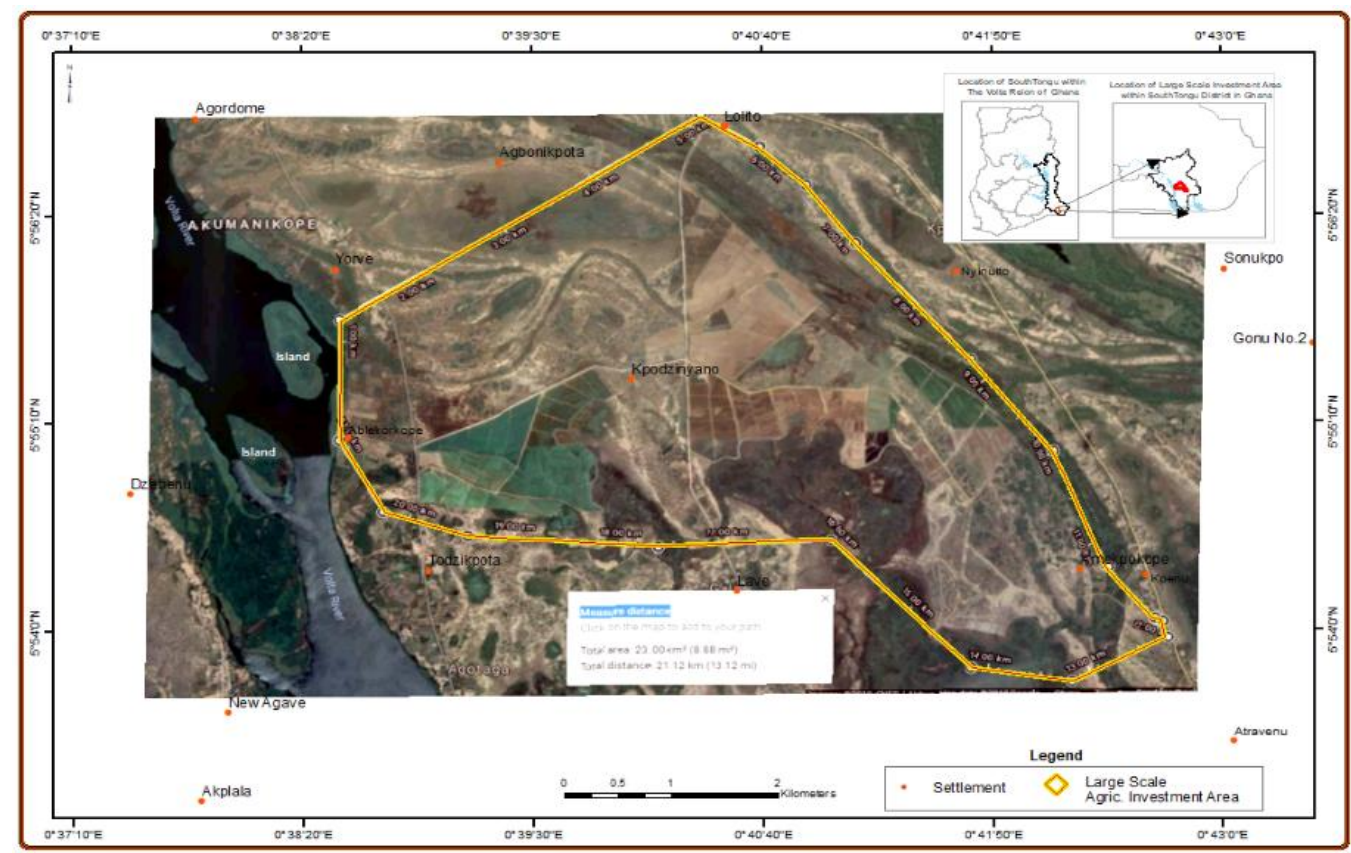

Figure 5.11: Map of South Tongu District of Ghana showing the Brazil Agro-Business Group Limited project area in 2018

Source: Author, 2019

The study adopted a case study design approach using qualitative methods that embraced the pre- and post-introduction studies. These methods were used since the effects and impacts of investments happened after the investments were made. The investigation was carried out in the former jatropha spaces in South Tongu District to understand the impacts resulting from changing investments. For this reason, a qualitative descriptive approach was adopted for this chapter, as it is flexible and relevant for a concentrated and detailed analysis of the work (Yin, 2003; Yin, 2006; Yin, 2017). The method was used to ensure a long-term engagement with the respondents, which helped to better understand multiple realities and the cultural attributions and to substantially use 'insiders' revelation', as suggested by Geertz (1973). Data were collected periodically from 2014 to 2018 . This approach ensured that emerging realities were identified and studied to inform the conduct of the study. The approach was also informed by a problem-oriented provision based on the question 'What was/is the impact during and after jatropha?' This also helped to examine the perceptions of community members and key 
stakeholders based on their experiences in the study community regarding the periods of changing investments (from jatropha to rice). To clearly present the realities, the findings are presented in a logical pattern of story-telling for easy understanding.

Table 5.4: Summary of project in Lolito area

\begin{tabular}{|c|c|c|}
\hline \multicolumn{3}{|l|}{ No } \\
\hline a. & Former land use & Cropland, flood plans \\
\hline b. & Ecological zone & Coastal shrub and savannah \\
\hline c. & Water management for agriculture & Rain-fed and small-scale irrigation \\
\hline d. & Average temperature & $14-28^{0} \mathrm{C}$ \\
\hline e. & Soil type & Coarse texture, alluvial \\
\hline f. & Land acquisition process & Broker \\
\hline g. & Compensation issues & No \\
\hline h. & Consultations with communities & No \\
\hline i. & Land title type & Lease \\
\hline \multirow[t]{7}{*}{ j. } & Jatropha investment & \\
\hline & - Investor origin & Norway \\
\hline & - Start year & 2006 \\
\hline & - Year of abandonment & 2010 \\
\hline & - Land acquired & 2,300 ha \\
\hline & - Land cultivated & 400 ha \\
\hline & - Number employed in peak season & 150 \\
\hline \multirow[t]{7}{*}{ k. } & Rice investment & \\
\hline & - Investor origin & Brazil \\
\hline & - Start year & 2011 \\
\hline & - Land acquired & 2,300 ha \\
\hline & $\begin{array}{l}\text { - Intended land acquisition and } \\
\text { expansion }\end{array}$ & 5,000 ha \\
\hline & - Number employed in peak season & 200 \\
\hline & - Land cultivated & 1,600 ha \\
\hline
\end{tabular}

In 2014, preliminary surveys and actual fieldwork started with the collection of primary data. An interview guide, focus group discussions and participant observations provided the means 134 | P a g e 
for the collection of the primary data from the respondents, and this was complemented by telephonic contacts and audio recordings. Respondents selected for the study in Kobre met the following criteria: must be a local resident (indigenous or migrant) farmer, and a local residents who had lived in the study communities for at least four farming seasons before the commencement of the jatropha investments.

Table 5.2: Key informants and participants in focus group discussions (FGDs) in Lolito

\begin{tabular}{|c|c|c|c|c|}
\hline Lolito & Type of respondents & FGD participants & $\begin{array}{c}\text { Key informant } \\
\text { interviews }\end{array}$ & Total \\
\hline & $\begin{array}{l}\text { - Biofuel Africa / Brazil } \\
\text { Agri-business } \\
\text { (company }\end{array}$ & & & \\
\hline & workers/management) & 39 & 1 & \\
\hline & - Farmers & 48 & 5 & \\
\hline & - Ministry of Food and & & & \\
\hline & Agriculture & & 2 & \\
\hline & - Traditional land owners & & 8 & \\
\hline & - District Assembly & & 4 & \\
\hline & - Broker & & 1 & \\
\hline Subtotal & & 87 & 21 & \\
\hline Total & & & & 108 \\
\hline
\end{tabular}

Two main sampling techniques were used to collect data, namely purposive and snowball sampling techniques. Through these techniques, a total of 108 people were selected as key informants and participants in FGDs to understand the concerns and complexities within the study area. Each interview and FGD lasted 30-60 minutes. Primary data were mostly collected by note taking and audio recordings. The respondents were selected through purposive and snowballing sampling techniques.

\section{Key informant interviews}

To gain an impression of the study area, face-to-face interviews were conducted with 21 key informants between 2014 and 2018. The key informants were one key informant from Brazil Agro-Business Group who was engaged as a large-scale investor, five individual farmers who 
were directly affected the investments, two key government officials connected to the project at the district level, eight traditional landowners and stool land representatives who had taken part in the land negotiation and acquisition process, four Assembly members from the districts affected by investment abandonment, and one broker who had played a role in the acquisition of land and agri-investment projects in the study areas.

\section{Focus group informants}

In Lolito, the research mainly used focus group discussions (FGDs) with farmers, migrant farmers, former employees of Biofuel Africa Limited and employees of Brazil Agro-Business Group Limited. Three rounds of FGDs were conducted to explore the direct and indirect impact trajectories of jatropha investment and the aftermath of jatropha investment from 2014 to 2018 . The participants in the FGDs were 39 company employees who had been engaged in largescale land acquisition and investment in jatropha spaces, and 48 farmers who were directly affected the jatropha investment and investment change to rice production. In order to interview respondents who were directly affected by the investments, farmers and employees were sampled based on the following criteria: must be a local resident of a community in or around the Lolito area and must have lived in the Lolito area for at least four farming seasons before the commencement of the jatropha investments. The in-person focus group discussions were composed of eight participants to ensure greater control of discussion subjects and allow each participant ample time to share their views and insights (Manoranjitham \& Jocob, 2007). Respondents' views expressed during FGDs were used to perceive community land use patterns before and during jatropha investment.

The first approach used in 2014 was purposive sampling to identify the first point of contact, which led to the establishment of a key informant linked to both projects. The initial institution consulted was the South Tongu District Assembly through the director of the District's Ministry of Food and Agriculture (MoFA), because they were connected to the communities through the extension services they offer the communities, and because of the role they play as the government's representative in the Ghana Commercial Agriculture Project (GCAP) where the government strongly supported the investors under the GCAP programme. After the snowballing approach was used to identify key informants through the District MoFA director, the extension officers put us in touch with the landowner, the head of the Tsiala clan, affected communities and key community members, company workers who were also community members, and the investors. After the initial identification of the key respondents, 
data collection was done in the investment community area every year from 2015 to 2018 . By 2018, a total of 108 respondents had been interviewed.

Data analysis was conducted in a descriptive manner, involving the drawing of valid inferences through the stories of respondents and the systematic evaluation of open-ended data collected through field surveys, as espoused by Paek et al. (2012). Datasets for analysis were obtained from both secondary and primary data. The secondary data were obtained from public documents, journal articles and other research materials. The primary datasets were obtained through a field exercise, during which an interview checklist was used to guide the FGDs and key informant interviews. Participatory community mapping was used to establish community perceived land use before and during jatropha investment (Figures 5.3 and 6.4). Data obtained from the study were analysed qualitatively. The results and discussions are mainly primary data, with some secondary data to support the findings. Before the analysis, all primary and secondary data were validated by five key respondents to ensure the data were true reflections of the issue examined in the study

\section{Results}

\subsection{Diverse land use before the creation of jatropha space}

Before the entry of investments in South Tongu, the people living in the investment area were largely rural-based agrarian and fishing communities that depended on economic activities such as farming, fishing, grazing, weaving, alcohol distillation and petty trading. The traditional clan heads control the land tenure system. The traditional setup is composed of five recognized autonomous traditional areas with independent landownership, namely Agave, Fieve, Sokpe, Tefle and Vume traditional areas. The land, which later became jatropha investment land, is owned by the Agave TC, which is made up of five clans and owns over 25,000 ha. The Tsiala clan, one of the Agave traditional clans, is the largest landowning clan among the five clans. This clan is headed by a clan leader who oversaw the negotiations of the jatropha land on behalf of the other members of the clan. The land negotiations were done in due consultation with the clan members and the 16 divisional chiefs of the Tsiala clan, who serve as the traditional overseers of the day-to-day administration of the villages and towns. The traditional-political dynamics of the Agave Traditional Area are such that the divisional chiefs deal with administrative issues while the Tsiala clan heads are responsible for land management and deals on behalf of the divisional chiefs and community members (excluding migrants). 
We the Tongu people, more especially my clan and my tribesmen, have always had the privilege of using the main lands that I mostly allocate for farming and grazing purposes; and the floodplains that are also used as a common pool resources or planting of sugarcane with the purposes of distilling alcohol, harvesting of reeds for mat weaving, and fishing. (Tsiala clan head, $\left.{ }^{2} 2015\right)$

Except for migrant Fulani herdsmen, migrants - who are few in number - are mainly ewes ${ }^{3}$ from other parts of South Tongu District and nearby villages. The migrant Fulani herdsmen are largely caretakers for indigenous cattle owners or entrepreneurs in the business of cattle rearing. The migrants do not have user rights to land. The community members conformed to the traditional and property rights provisions in place. The indigenous people can lease their lands to migrants under locally agreed conditions without necessarily consulting the Tsiala clan head, but some migrants obtained user rights to land through agreement with the Tsiala clan head.

According to the traditional standards, the community members had first user rights to the land and could negotiate by presenting a drink (a bottle of gin) to the clan head and promising to pay a token annual rent of about GHS 10 (USD 2.1). Individuals could also enter into other forms of tenure such as a shared cropping system, annual renting of ponds for fishing, leases for the rearing of cattle and land leases for building purposes. The land tenure systems were quite flexible but highly regulated by the traditional structure. The social environment was conducive and provided a platform for cohesion and joint development initiatives for favourable and supportive local economic ventures. The traditional clan head allowed both indigenous people and migrants to use existing common pool resource, mainly flood plains, without any traditional tenure arrangement.

The flood plains made sugar cane farming a very successful activity especially during the rainy season. There were also crabs, which were harvested and sold by farmers. The presence of reeds, raffia and short grasses encouraged some community members to engage in basketry and mat weaving - a prominent source of income for women. The presence of clay also made pot making another activity commonly engaged in by women. Some people depended on the clay for brick and tile for housing. It was also

\footnotetext{
${ }^{2}$ The Tsiala clan head, the allodial title holder was interviewed at Ablekorkope, Tsiala Clan Head in 2015.

${ }^{3}$ The ewe tribe is an ethnic group in the Volta region of Ghana. All tribes in South Tongu District belong to this ethnic group. The language spoken by the ewe tribe is also known as 'ewe'.
} 
common to identify women engaged in firewood fetching. (FGD, women's group, 2015)

Most of the indigenous people and migrants had land to live on, since most of the indigenous elites had migrated to the cities and the population left in the area could sustainably depend on the land for their livelihoods without any competing claims to the land. This led to the proximate and convenient use of resources in the area. For example, farmers and fishermen confirmed that the proximate location to the Volta River and its associated creeks made fishing a commonly practiced economic activity. Pastoralists had permanent settlements in the area because the area was also suitable for cattle rearing and grazing.

The communities were predominantly known for cattle grazing. This was because of the presence of large tracts of land covered with short grasses, the absence of tsetse flies and a low rainfall pattern. (District MoFA officer, 2015)

The communities are closer to Dabala - the main market centre of the entire South Tongu District - and connected by a good road network, making mobility very easy and convenient. Land users, including farmers, pastoralists and common pool users, could easily sell their outputs because of intense demand, with the availability of a market for the incremental selling of produce. Most women were therefore traders who sold the produce of their husbands at the market to generate income for the entire household.

Socio-politically, the structured and traditional norms, land tenure and land use systems functioned in harmony without conflicts. These norms and the low population of resource users allowed the smooth communal use of common pool resources without conflicts. The stable traditional norms and equitable share in resource use minimized conflict in the area. The flexibility in customary provisions allowed both indigenous and migrant farmers easy access to land without the manifestation of conflicts. As a result, local cooperation and joint development initiatives were easily identified within the communities in the area.

Using participatory community mapping (Figure 5.3), the ecological conditions of the common pool and community land use before jatropha investments were perceived along with their livelihoods. The common pool resource mainly hosted indigenous species like neem trees and short savanna grass; the marshy land was home to with crabs and reeds, and creeks and rivers teemed with fishes. Additionally, the ecological conditions were suitable for wildlife such as sitatunga (a swamp-dwelling antelope), waterfowl, migratory birds such as egrets, francolins, 
kites and waver, and many other species of animals that could have been harnessed as an ecosustainability tourist site for local revenue generation. The socioeconomic activities correlate with the resources in the area where the pastoralists - mainly Fulani herdsmen - largely depend on the short savanna grass for cattle grazing. Also, parts of the land were suitable for vegetable farms, most of the indigenous people are fishermen and hunt for crabs in the marshy regions, local alcohol distillers depend on the marshy region for the cultivation of sugarcane to feed their local distillation plants (Photo 5.2), and women use reeds and raffia for mat weaving and basket making (Photo 5.1).

Table 5.3: Impacts before jatropha introduction in the Lolito area

\begin{tabular}{ll}
\hline Conditions & \multicolumn{1}{c}{ Respondents' knowledge of realities before jatropha } \\
\hline Environment & Presence of common pool resources sustainably exploited, e.g. reeds, \\
& raffia, clay, floodplains \\
- & No displacement of indigenous species because of low exploitation of \\
& the land. Presence of indigenous species e.g. sitatunga amphibious \\
& antelope, water fowls, migratory birds such as egrets, francolins, kites \\
& and wave \\
- & Sustainable use of creeks and rivers for fishing and irrigating farms. \\
& Presence of creeks and rivers (e.g. the Ekpe, Lolidze and Volta), various \\
& varieties of fishes including tilapia and fresh water clam locally known \\
& as adode. \\
- & Sustainable exploitation of neem for medicinal and firewood purposes. \\
- & Presence of short grasses. Sustainable exploitation by pastoralists and \\
& farmers. \\
\hline & - Indigenous and migrants have access to traditional landowners and \\
- & systems for farmlands and grazing. \\
- & Different livelihood options, sustainable livelihood e.g. raffia for mat- \\
& weaving, sustainable harvesting of neem trees for firewood, and pottery \\
& making, planting of sugarcane and distillation of alcohol for sale. \\
\hline Socioeconomic & Access to common pool for grazing and free movement of pastoralists.
\end{tabular}




\begin{tabular}{ll}
\hline Political & No broker interference in land deals; land deals made directly with \\
& landowners. \\
- & Limited or no internal conflict between land-owning clan and \\
& community members on land issues; no competing claims to land \\
& resources. \\
- & Strong attachment to traditional values and community use of resources \\
& demonstrate stable local norms to protect local people from external \\
& threats.
\end{tabular}

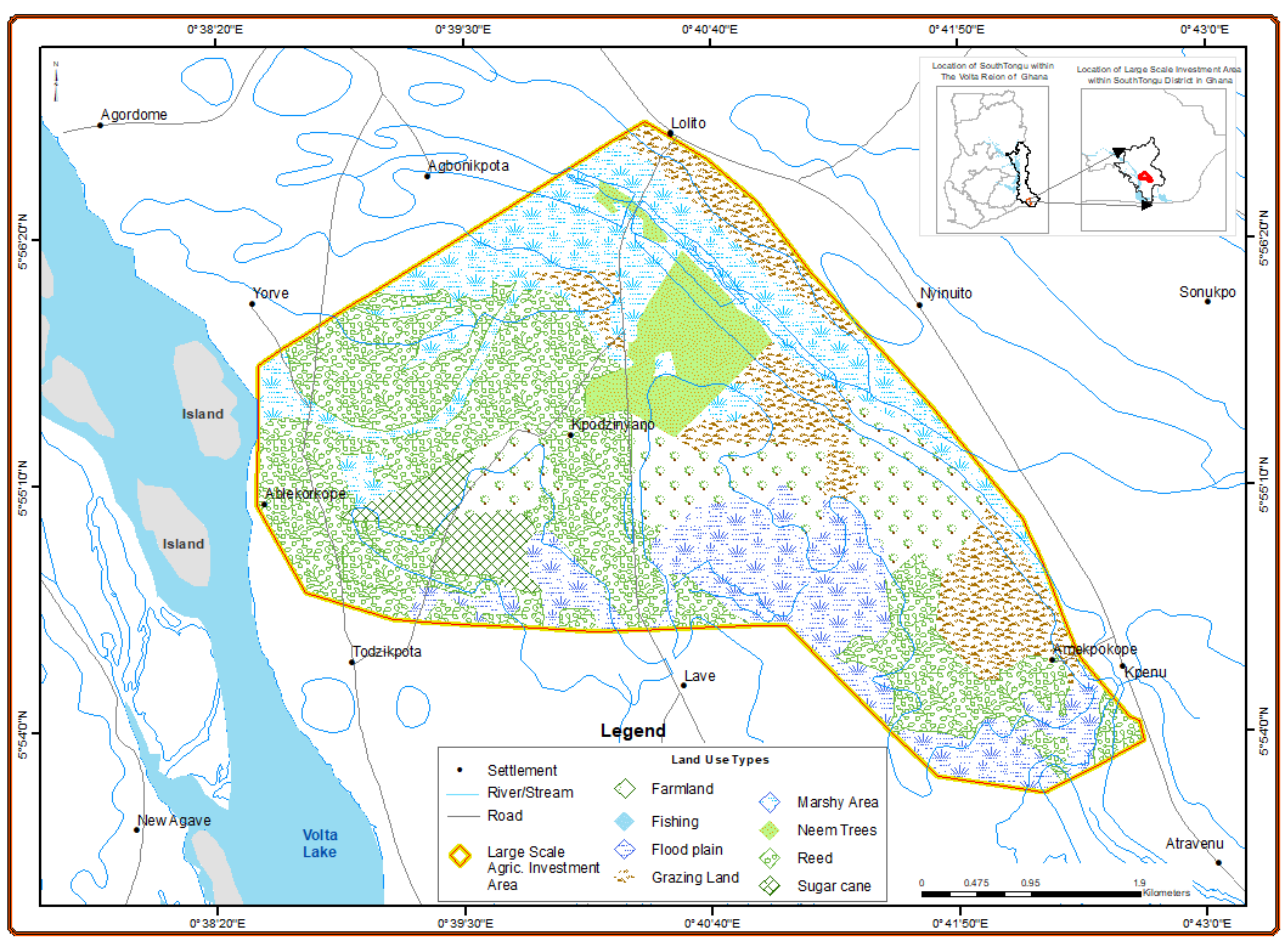

Figure 5.12: Map of South Tongu showing community perceived land use maps before jatropha investment

Source: Author, 2019 


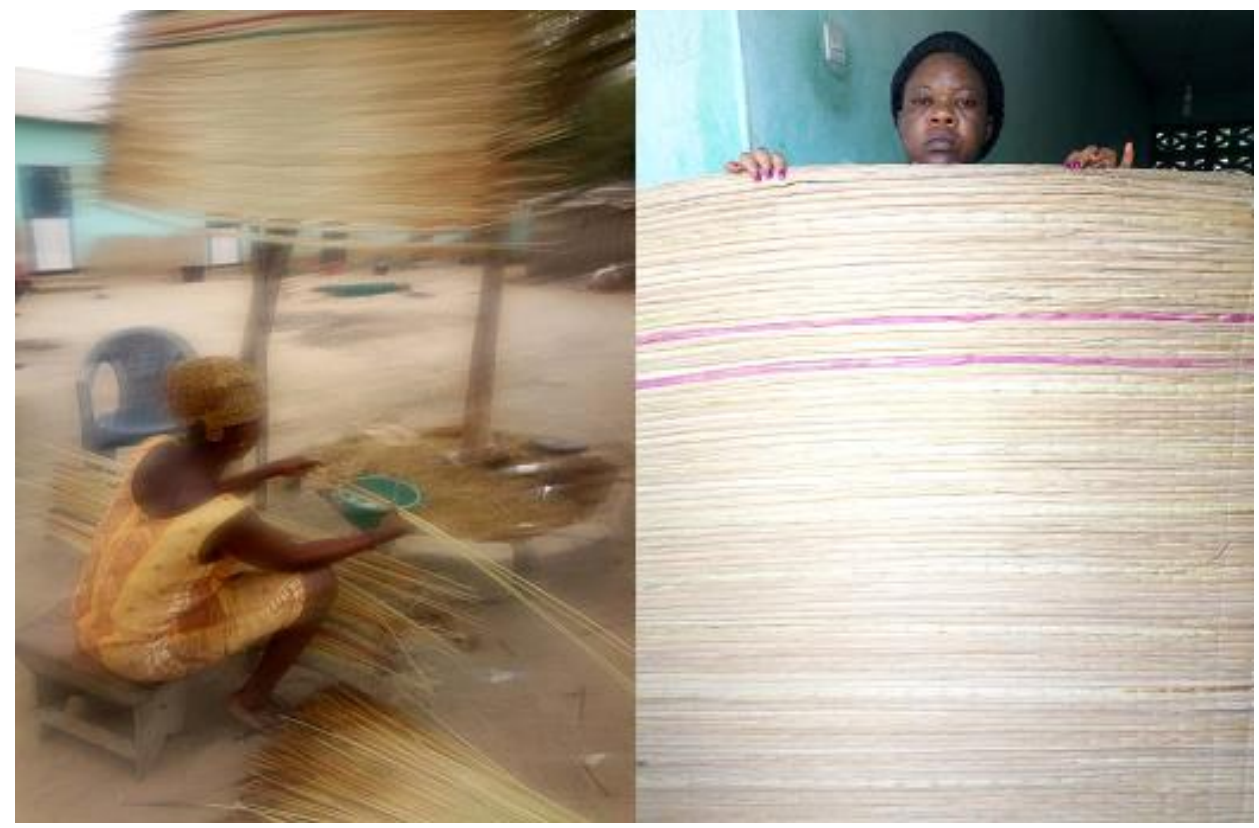

Photo 5.26: Mat weaving, one of the community livelihood activities

Source: Field survey, Author, 2016

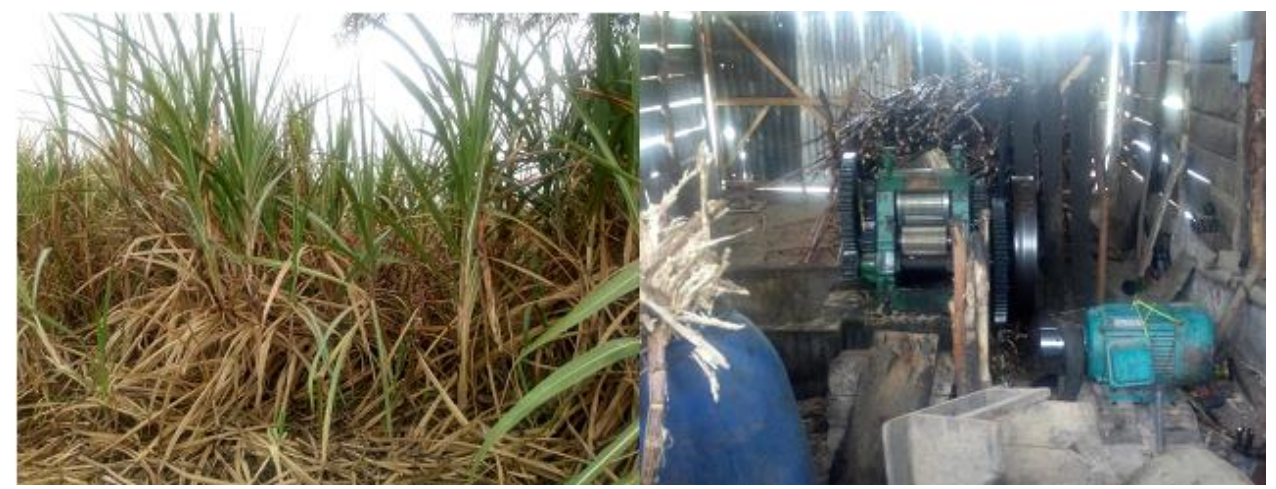

Photo 5.27: Sugarcane cultivation in marshy area to feed the processing plant for alcohol distillation in the South Tongu area

Source: Field survey, Author, 2014

\subsection{Creation of jatropha space}

The jatropha investment was introduced by a member of the indigenous population, namely Professor Lade Wosornu, who had moved to Saudi Arabia but wanted to be part of the community development agenda. Having realized that his own community needed development 
and had a huge amount of land for agrarian investment, in 2005 Professor Wosornu leased about 2,300 ha, which were mostly being used by common pool users (e.g. pastoralists, farmers, mat weavers and potters) who depended on the land for their livelihoods.

As the head of the Tsiala clan and the landowning clan, I leased 2,300 hectares to Professor Lade Wosornu, a renowned physician-surgeon, businessman and a native of the community, which he promised to utilize in the near future to enhance the development of the community. (Tsiala clan head, 2015)

As a business-minded individual with extensive experience, in 2006 Professor Wosornu met Norwegian Biofuel AS, an investor group based in Norway. This group was already interested in the potential of jatropha through the wave of global enthusiasm for the crop (Sanderson, 2009), particularly as an alternative to fossil fuel and a climate mitigation strategy (Sulle \& Nelson, 2009; Birega, 2008; Bassey, 2008; Hill et al., 2006; Openshaw, 2000). The investor group was therefore prepared to commit resources to the crop's investment. As Allan et al. (2013) have contended, Africa has always presented itself as an ideal location for agricultural commercialization due to the continent's favourable biophysical resources. Again, the ineffectiveness of legal processes and institutional pluralism has persistently served as a catalyst for large-scale agricultural commercialization (Batterbury \& Ndi, 2018). Amidst other appealing African countries, Ghana is specifically preferred by some foreign investors due to the political stability, abundant natural resources, favourable climate and presence of productive lands for agri-investments (Aryeetey \& Udry, 2010). Biofuel AS therefore decided to invest in Ghana, once Professor Wosornu had made land available. The land was subleased to Biofuel AS, which opened a subsidiary in Ghana - Biofuel Africa Limited.

As an elite and industrious person in my traditional area, Professor Wosornu was able to convince me and my family members that he was now ready to utilize the acquired land to enhance development, as already promised. He introduced the foreigners as individuals who would be utilizing the land for large-scale jatropha. We agreed; after all, we had already leased the land to him. (Tsiala clan head, 2015)

The investment was expected to improve the living conditions of the local community. In this regard, the landowner was convinced about the positive outcomes of the proposed jatropha investment. The process of land lease from Professor Wosornu to Biofuel Africa Limited went 
smoothly without due consultation with the potentially affected communities, especially Lolito. This implied that a large number of the community members were unaware of the investment. They were informed only when the employment process started, and they mostly benefited from the employment created.

Even the initial stage of land acquisition by Professor Wosornu in early 2005 was not known to the local community members, and without proper consultation at the time of the jatropha investment, community members still accepted the investment. (Anonymous local farmer, Lolito, 2015)

\section{Operations in jatropha space}

Biofuel Africa Limited started with a 400-ha jatropha demonstration farm in 2007 (Figure 5.4). This meant that 1,900 ha remained unutilized.

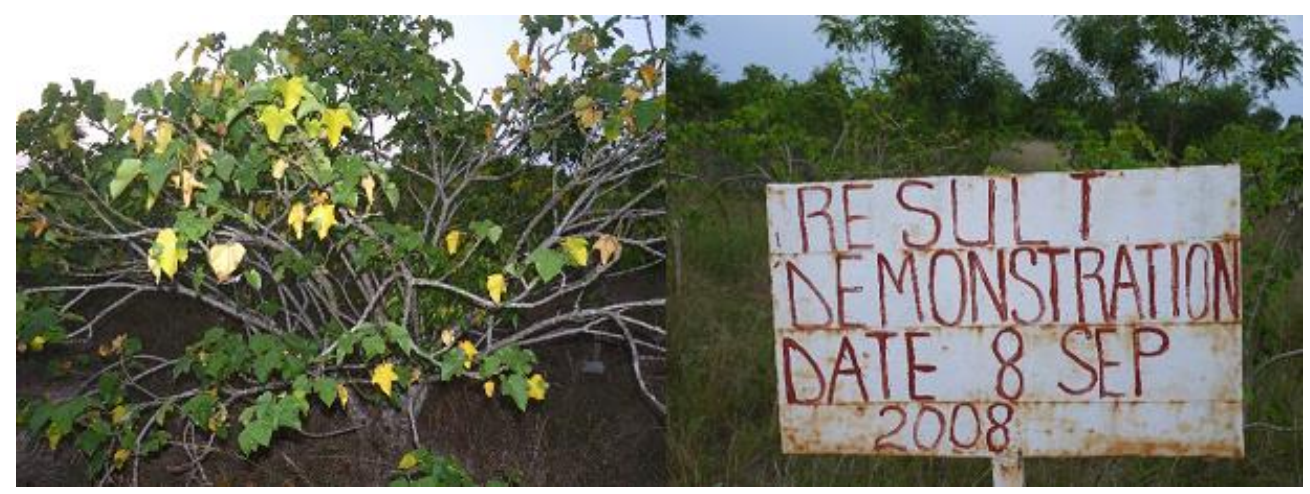

Photo 5.28: Biofuel Africa Limited jatropha demonstration farm at Lolito.

Source: Field Survey, Author, 2011

Though the initial plantation was just a demonstration farm, the consequences of the landscape alteration deprived local people of some of the ecological benefits and non-timber forest products (Figure 5.4).

Some community members were using some portions of the jatropha land for crop production whilst others were using other areas as grazing grounds for their cattle. There were reeds growing for making mats, but the acquisition 
and alteration of the land limited individuals' free movement to access the reed. (FGD, 2015)

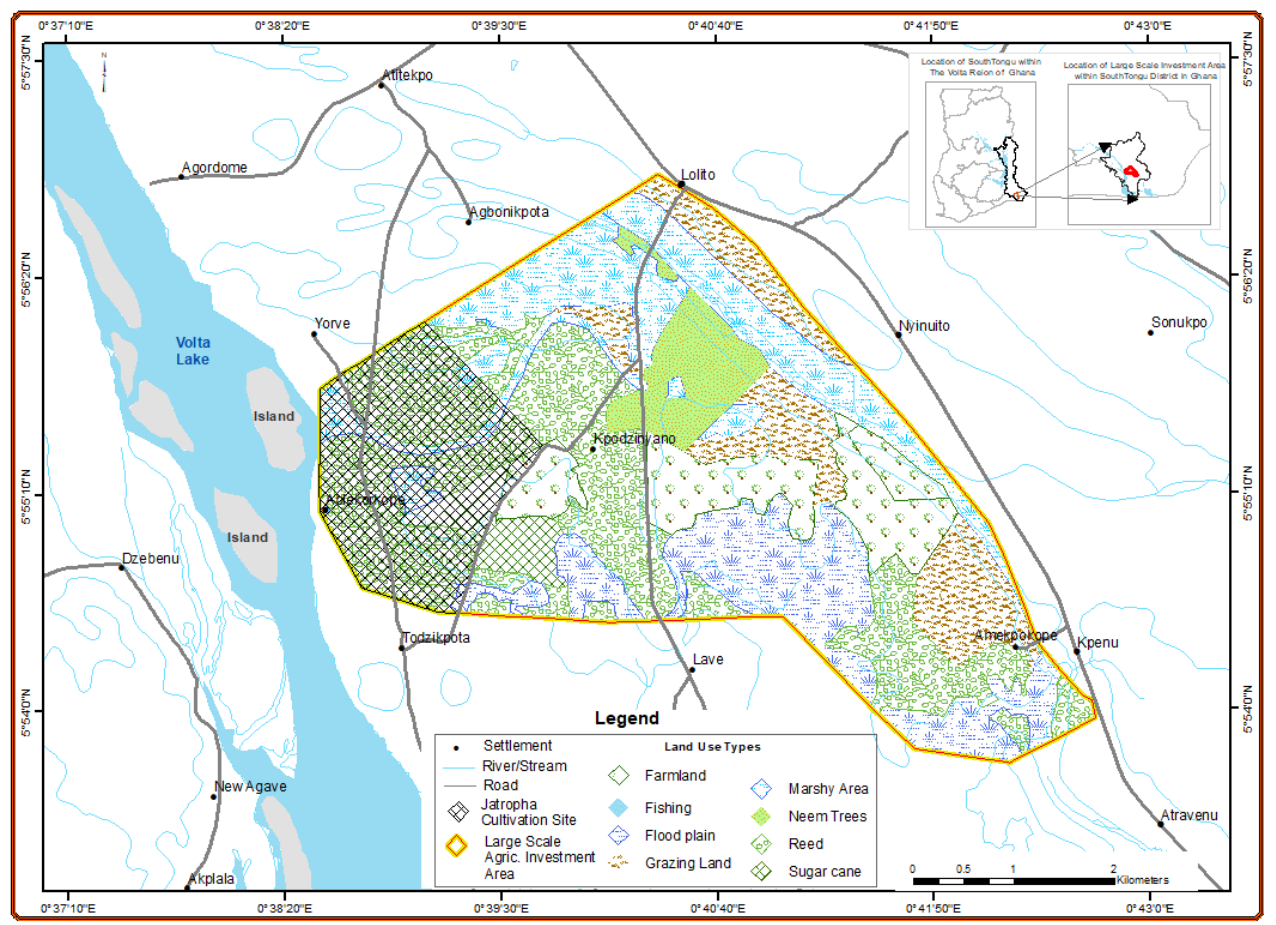

Figure 5.13: Land use and land cover in the Lolito area during the jatropha era Source: Author, 2019

During its operations, the investor employed 80 workers on a temporary basis, mainly members of the local communities; this figure was increased to 150 workers during the peak season. It trained some as tractor and machine operators and the rest as farm labourers. The workers received a monthly salary of between GHS 80 and GHS 120 (about USD 21-32), depending on their job type and role, such as supervisor, security staff, field worker, tractor and equipment operator and repairer.

We were happy to be employed because we were guaranteed a monthly salary, but we were generally not satisfied with the amount of money given to us as salaries for our services. (FGD, workers, Lolito 2015) 
Even though employees were not satisfied with their pay and allowances, other opportunities arose. For example, some were trained to operate and repair tractors and other equipment. Thus, there was technology and knowledge transfer to some community members, which is often seen as one of the benefits of commercial investments. Another move by Biofuel Africa to resolve community and workers' agitation was the intention to improve the economy of the affected communities by introducing an out-grower scheme by 2011 (FGD, workers, Lolito, 2015) after a successful jatropha farm demonstration. However, this never materialized because of the collapse of the jatropha project.

During the farm demonstration stage of the project, Biofuel Africa Limited resolved to allow the common pool users to use the idle land for their activities. Individuals engaged in fishing were not prevented from accessing the portion of the Volta River adjacent to the demonstration sites. Thus, small-scale farmers, particularly those engaged in vegetables and sugar cane farming, and fishermen were able to continue their economic activities. In some cases, women who depended on the reeds and short grasses for mat weaving and other products could still use the idle portions of the land.

The broker, Professor Wosornu, initiated other initiatives to enhance community economic growth and empowerment. He had negotiated with Biofuel Africa in 2008 to accept a foundation (the Wosornu Foundation) he had formed in Lolito and to incorporate it as part of its corporate social responsibility (CSR) agenda to empower the community members by contributing to community education and training through scholarships, and technology transfer through the out-grower scheme with the intention to experiment with different seeds and the mechanized harvesting of grains, and for community development and empowerment (FGD, 2015). All these provisions put in place by the investors and Professor Wosornu were to enhance cooperation between community members and investors and to build the capacity of the community members. 


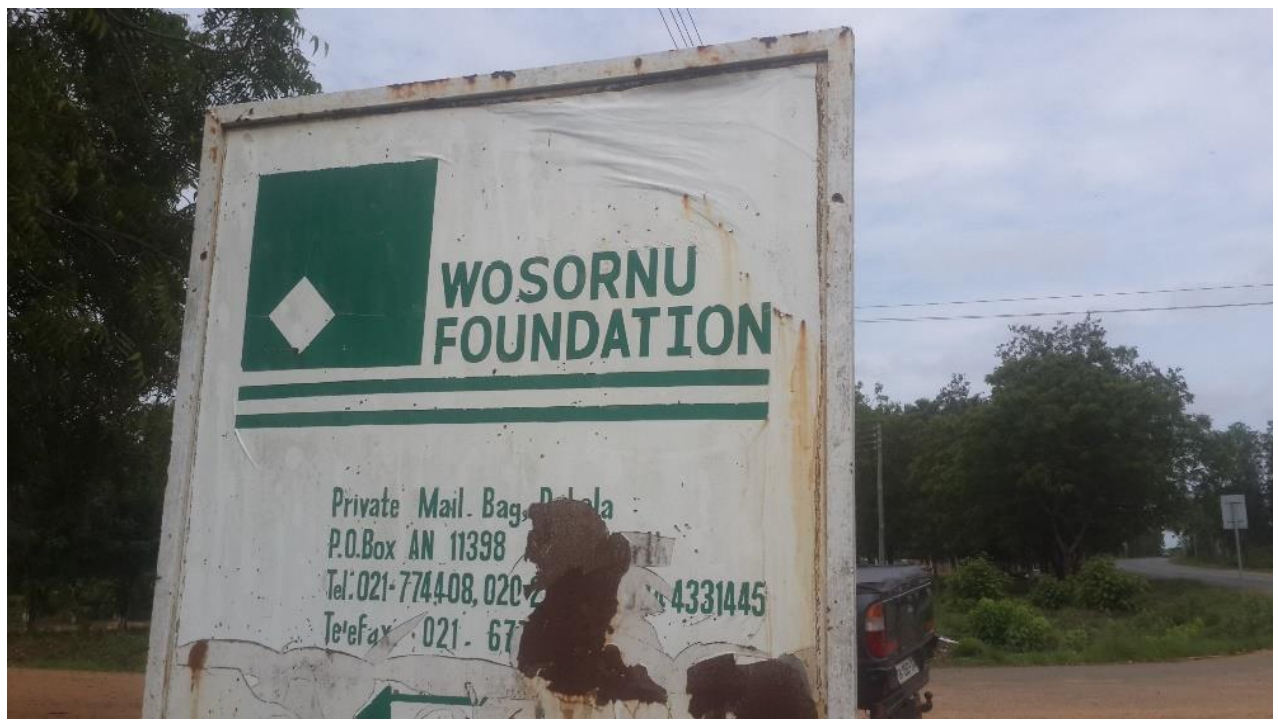

Photo 5.29: A Wosornu Foundation sign in Lolito

Source: Field survey, Author (2015)

\subsection{From jatropha to rice monoculture}

\section{The collapse and exit of jatropha}

As jatropha incrementally proved unsuccessful by 2010, workers were frequently laid off until there were only 10 left (five security staff to safeguard the company's properties and five administrative staff to assist with administrative work and to close the accounts to end the business operations). Due to the unprofitable nature of the jatropha business, the investor had difficulties paying the workers. Thus, some workers were laid off without payment, and this created tension between the investor and the community, until the investor left in November 2010 without formally informing the landowners or the community of its exit. Subsequently, at the end of 2010, Professor Wosornu took charge of the land again and started looking for another investor.

After the abandonment of the jatropha farm by Biofuel Africa Limited, Professor Wosornu took back the land ... How the land was transferred back to Professor Wosornu after the collapse of jatropha is unknown to us. (Field interview, Tsiala traditional clan head, 2015) 


\section{Transition from jatropha to rice cultivation}

By the second half of 2010, Professor Wosornu had met another investor, Brazil Agro-Business Group Limited (BABGL), for commercial rice production. Rice production was suggested because the jatropha land was located close to the Volta River and some of the land on the flood plains was suitable for waterlogged crops like rice. Professor Wosornu subleased the land to BABGL without involving the landowner (the Tsiala clan head) in the negotiation and leasing process. When the landowner became aware of the proposed operations of BABGL, he asked Professor Wosornu for re-negotiation arrangements, which Professor Wosornu refused, leading to a brewing conflict between them. The landowner then used his authority to prevent BABGL from proceeding with the project. This triggered a second negotiation between the investor and the landowner. The investor had, however, paid an unknown amount of money to Professor Wosornu.

By the time I became aware of the dealings of Professor Wosornu, the only solution I had was to stop the investors and enter into a new and direct negotiation with them as the landowner ... (Tsiala clan head, 2015)

Thus, BABGL entered into an agreement with the landowner and in 2011 proceeded to start cultivation. BABGL, in consultation with the Tsiala Clan head, informed the community members and started employing both skilled and unskilled labourers.

In fact, the initial lease agreement between Professor Wosornu and the landowner [head of the Tsiala clan] for the jatropha project had already incited some form of tension and conflict between the divisional chief and the clan head because of the lack of due consultation during the lease of the land to Wosornu. Hence, the head of the Tsiala clan needed to act with caution and start consultations to protect the interests of the community in subsequent agreements. (Anonymous key informant, Lolito, 2015)

The investment initiated by BABGL was strongly supported by a governmental initiative under the Ghana Commercial Agriculture Project (GCAP). It was expedient for BABGL, because before it had begun cultivation in 2011, it had prepared a proposal to be considered for the GCAP, which was to be implemented in 2012 through the Ministry of Food and Agriculture with funding support from the World Bank and USAID. By 2013, BABGL was one of the 31 firms in the GCAP. The GCAP had a matching grant scheme to leverage private investment to $148 \mid \mathrm{P}$ a g e 
spur inclusive and competitive agricultural growth that integrates smallholder farms into commercial agriculture in Ghana. BABGL had obtained funding support through the GCAP to integrate a rice farming project on the 31 ha that operated under out-grower schemes. About 30 farmers have been employed through the GCAP programme, in which their produce is bought, processed and sold by the investor, helping the beneficiaries to obtain ready income with the intent of benefiting the community.

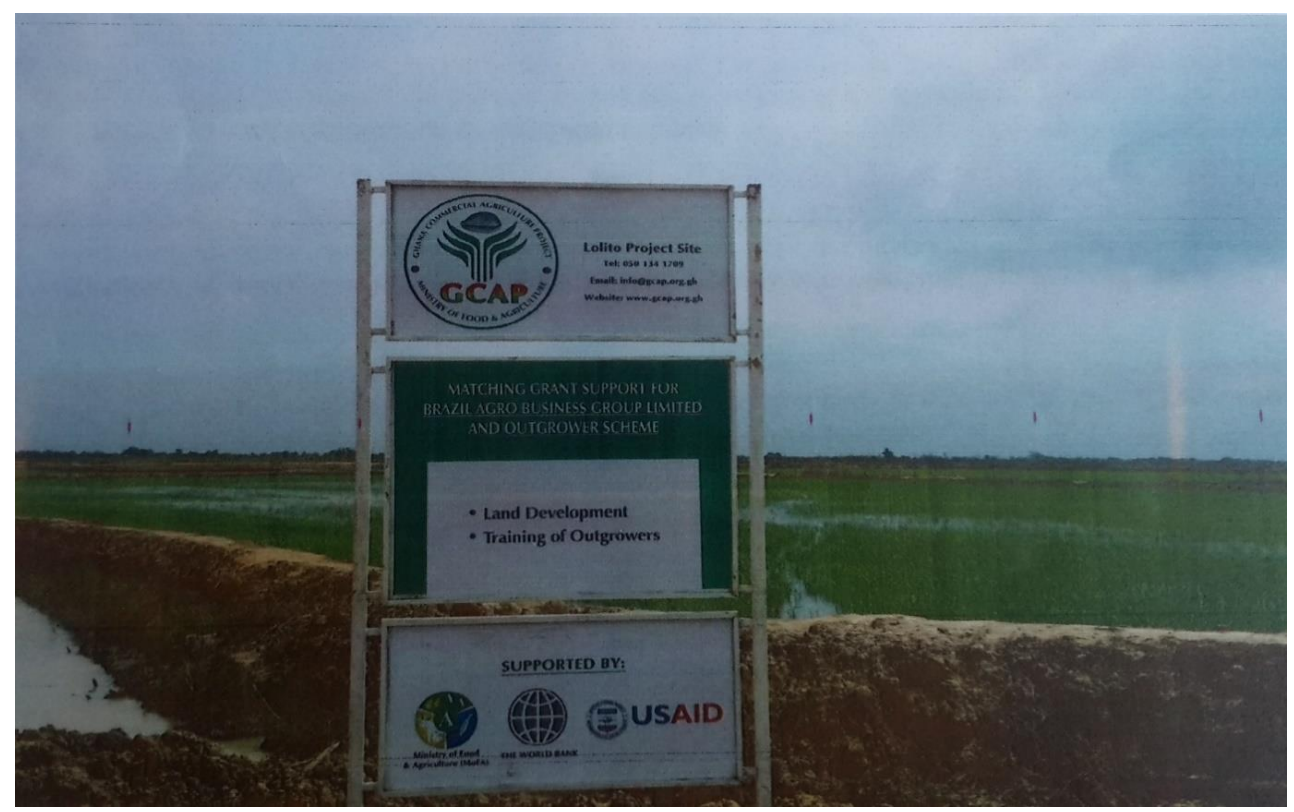

Photo 5.30: Site of the BABGL out-grower scheme for rice cultivation for 30 community members.

Source: Author, 2015

The company's operating strategy was based on four strategic business models: employment of 200 members of the community; knowledge transfer by building the capacities of the communities in agronomic practices of cultivating rice; using the GCAP initiative to integrate the out-grower scheme as a business model, the piloting of 30 member out-growers and cultivating about 13 ha of rice farm under the GCAP; and technology transfer by training community members to operate and maintain the machines, including combine harvesters, tractors, mills and factory equipment. According to a key informant in 2017, the BABGL strategic business model facilitated the coexistence of the community members and the investors, but not the unemployed. 


\subsection{Impact of rice cultivation}

Once the land issues were settled, BABGL started to build the irrigation infrastructure, which involved sourcing water from the Volta River through a canal irrigation system (Photo 5.3.1) for the rice farms. This was followed in 2011 by the preparation of 1,600 ha for the cultivation of rice. Since 2018, the area under rice has been expanded to almost 2,300 ha (see Figure 5.14), which has had its impacts (Table 5.4).

Table 5.4: Impacts of rice production in the Lolito area of South Tongu District

\begin{tabular}{ll}
\hline Conditions & \multicolumn{1}{c}{ Respondent knowledge of realities after jatropha } \\
\hline Environment & - Conversion of jatropha to rice and cultivating 2,300 ha and intention to \\
& expand to $5,000 \mathrm{ha}$; pollution of nearby rivers with chemicals, \\
& construction of dusty road causing pollution. \\
- Ecological resources are facing a severe threat from the gradual \\
expansion of investment operations. No access to common pool \\
resources.
\end{tabular}

Socioeconomic

- Out-grower scheme initiated through GCAP. Integrating out-grower scheme business model and the piloting of 30 member out-growers cultivating about 13 ha under the Ghana Commercial Agriculture Project (GCAP)

- Livelihoods have generally worsened, since all local economic actors (farmers, herders, mat weavers, fishermen, etc.) have been denied access to and use of land and other natural resources.

- Limited or no access to common pool resources like reeds, clay, raffia and neem.

- Employment of 200 community members.

Socio-political - Broker subletting land to new investor leading to an agreement between investor and landowning clan; conflict situations moderated because of investment (e.g. out-grower scheme); indigenous people can reconnect to opportunities created through investment. 


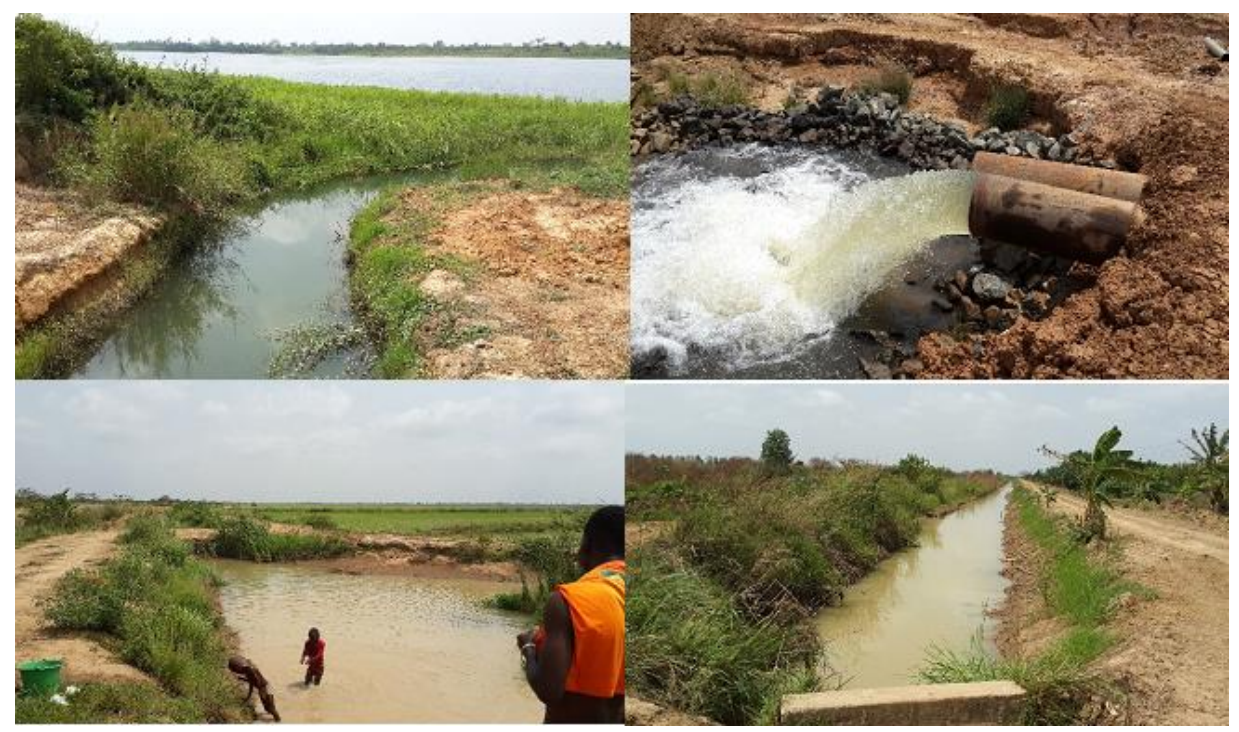

Photo 5.31: Irrigation infrastructure sourcing water from the Volta River to irrigate the rice farm

Source: Field survey, Author, 2015

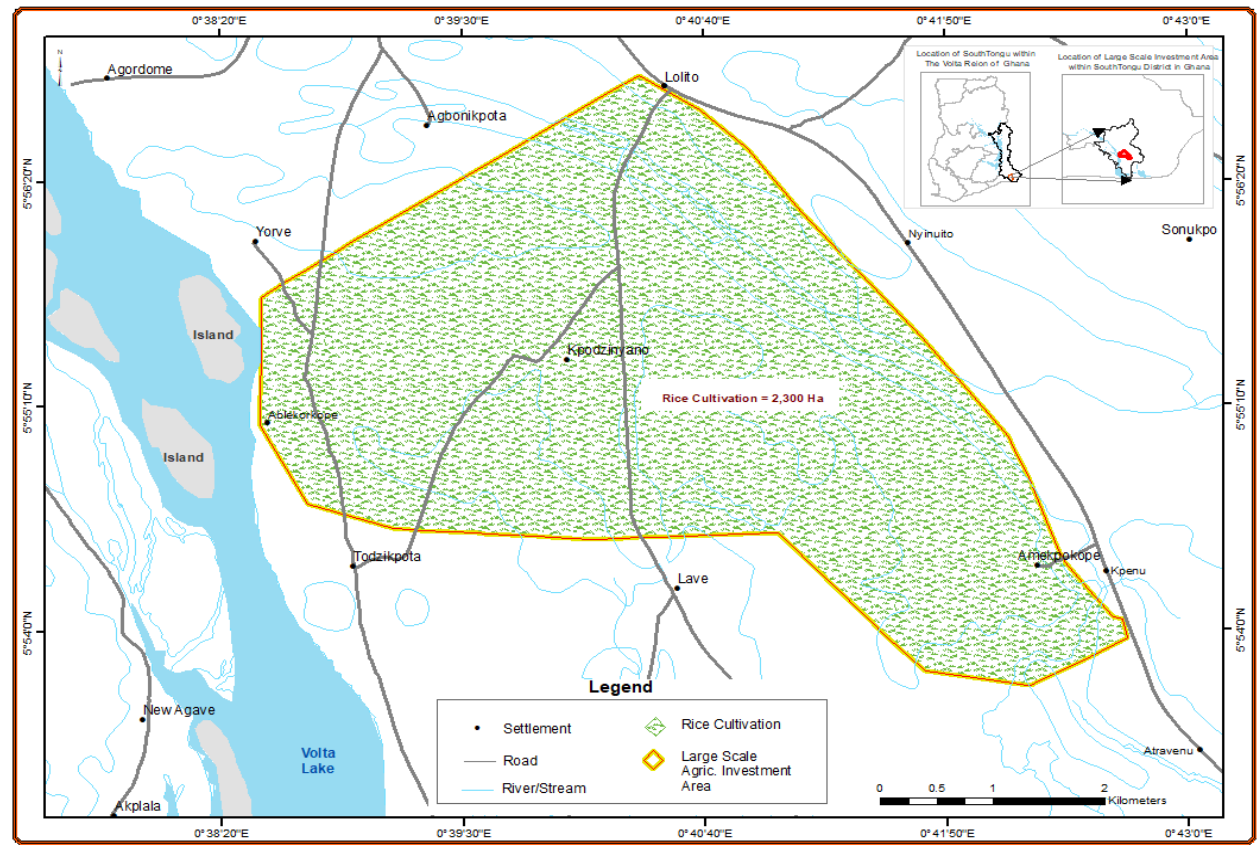

Figure 5.14: The current rice cultivation area of Brazil Agro-Business Group Limited in South Tongu District.

Source: Author, 2019 


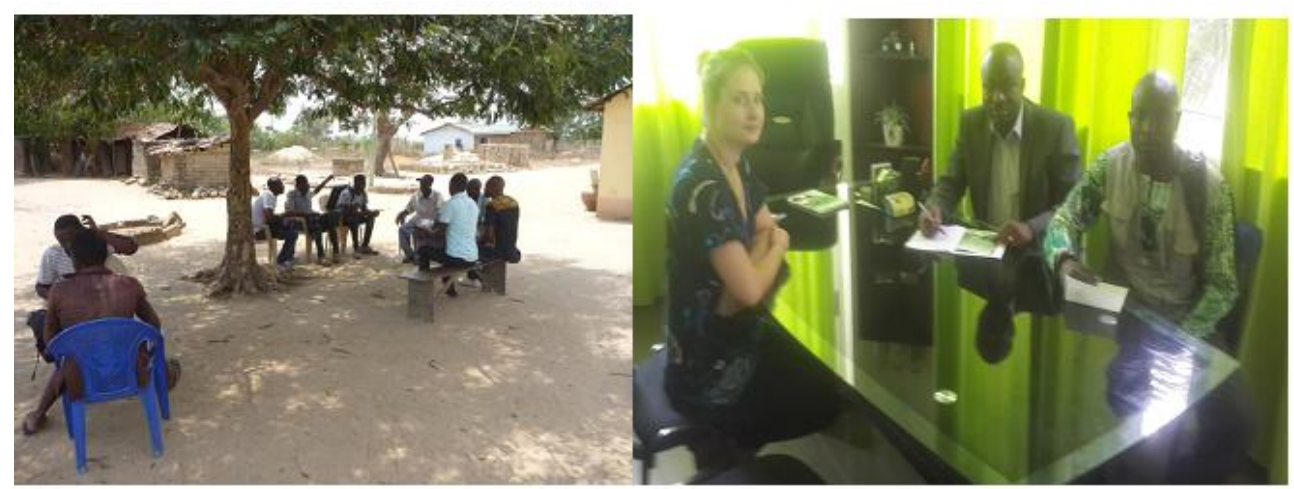

Photo 5.32: Interviews at Lolito with key informants (left) and with the manager of Brazil AgroBusiness Group Limited and the MoFA District Agric Officer (right).

Source: Field Survey, Author, 2017.

By 2017, the landscape alteration had led to the major displacement of communities that had been utilizing the land for their livelihoods. Unlike Biofuel Africa, which had allowed some community members to use its unused lands, BABGL has cleared and prepared all parts of the acquired lands. Almost all the common pool resources have been cultivated within the 2,300ha investment area; consequently, a large number of common pool users in the affected communities are dissatisfied with the operations of BABGL. The fact that the highly commended development was only beneficial for some 200 people, meant that the majority of the common pool users were dispossessed.

The continuous expansion of the rice farm is an indication that BABGL will operate in the project area for a longer period of time compared to the jatropha investor, and also indicates that more livelihood marginalization on the part of the community members will persist. (MoFA officer, 2017)

The switch from jatropha to rice has led to drastic changes in the landscape. All vegetation on the land was cleared to make way for rice cultivation (Photo 5.7), thus depriving the community members and common pool users of their farmlands, grazing lands and access to firewood, as well as fishing in streams and mat weaving. The landscape alterations created by BABGL tend to be more severe than the jatropha era, when the jatropha investor allowed grazing and the 
collections of non-timber forest products. Thus, most of the pastoralists have away migrated from the area to other spaces. According to a women's FGD in 2017, there were many neem trees growing on the now-submerged land and their husbands used to help them harvest firewood for domestic and economic purposes. The trees were green, and they could use them for shade even during the farming season, but now they are almost gone. The district MoFA director supported the claims in his statement that:

It is estimated that for every 500 hectares accessed by the investor, about 100 local people lose their livelihood sources, and the clearing of raffia, neem and reeds affects over 200 weavers and cattle ranchers. (District MoFA director, 2016)

The fact that the expansion of the investment meant more employment for the common pool users in the affected communities did not mean the common pool users were content. The common pool users who were employed by BABGL felt that their control over their resources and privileges had been taken away from them. They had lost the advantages of being selfemployed while working under the new investment dynamics, which is different from their livelihood independence.

Before the investment, people were self-employed with different forms of livelihood and this area was largely known as a 'multifunctional local community'. They are commonly identified with names like 'the clay community', 'the pot community' or 'the firewood community'. People now refer to these areas as 'the Brazilian community' due to the gradual takeover of the community by BABGL, a Brazilian company. (FGD, 2017)
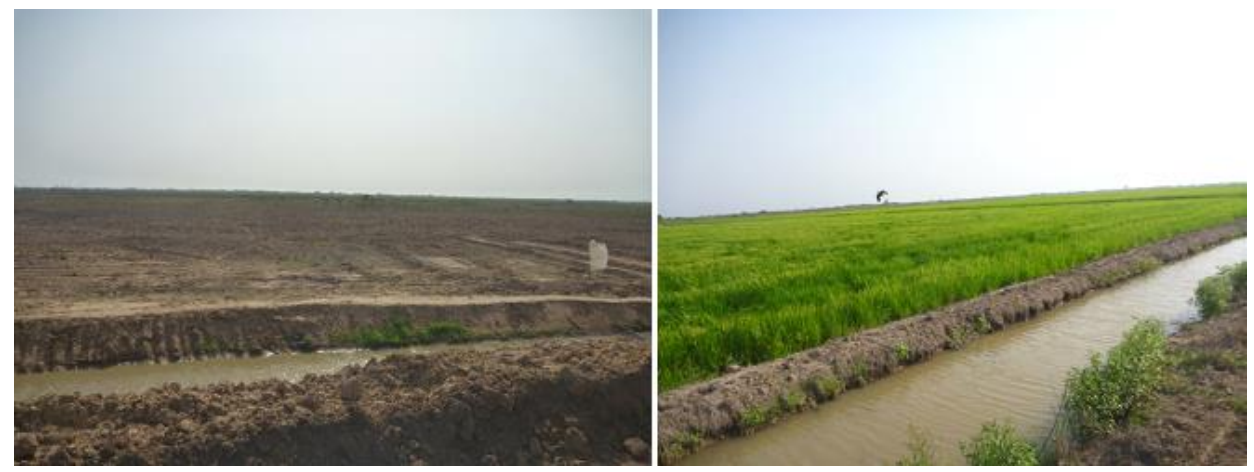

Photo 5.33: Site prepared (left) and cultivated (right) for rice cultivation

Source: Field survey, Author, 2016. 
In terms of the use of water resources, a vivid alteration of the ecological landscape occurred between Kpenu (the community hosting the factory office) and communities in the investment site (farm site), where the river previously used as a source for irrigation and fishing is blocked by a road that was built by the investor without consulting the community users.

The new investor has created a short-cut from its factory office at Kpenu to the farm site around Lolito. Unfortunately, the road has blocked a river source that was used for irrigation farming and fishing. Now the river has dried up. (FGD, opinion leaders Kpenu, 2017).

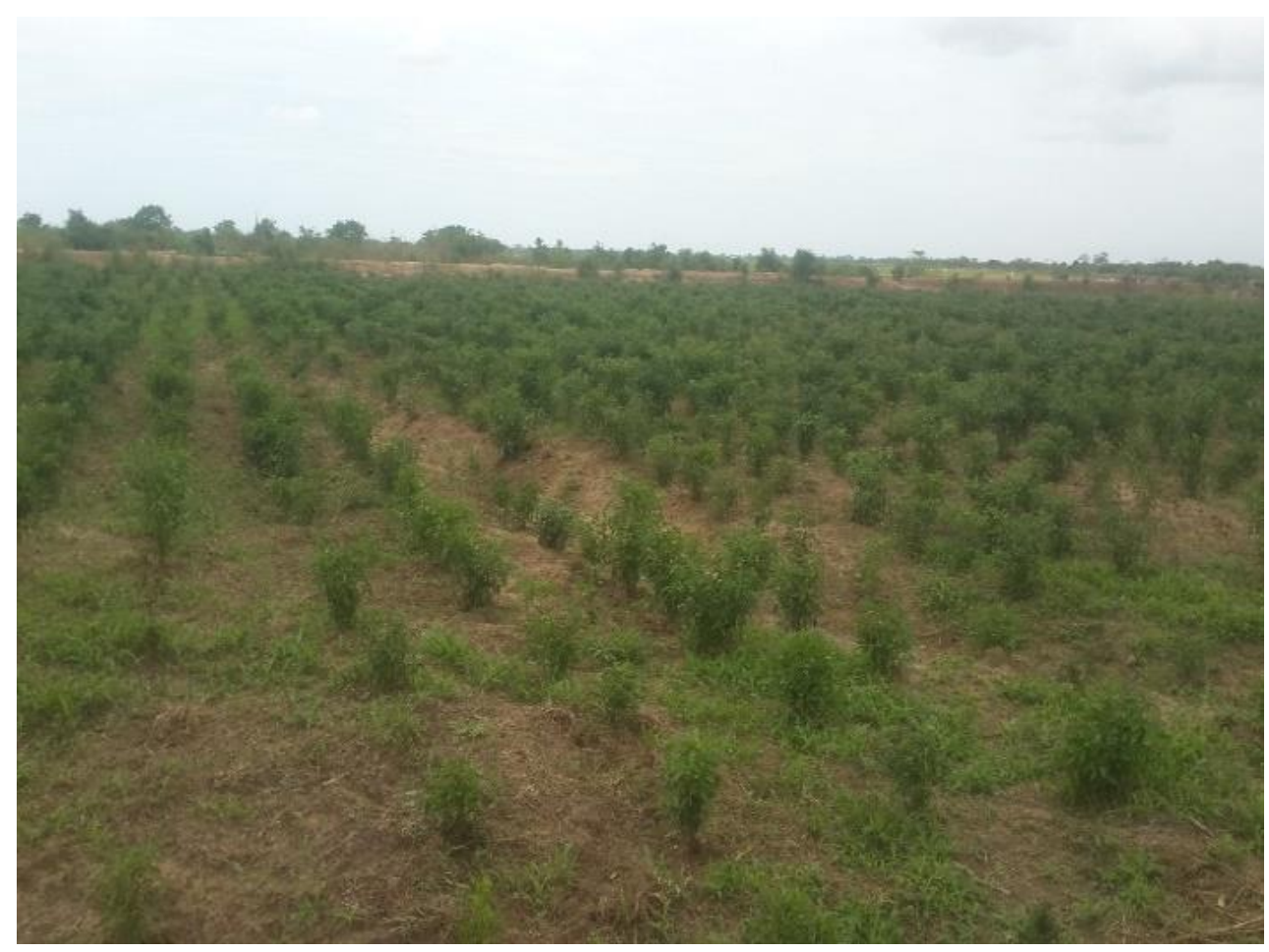

Photo 5.34: Farm adjoining the investment threatened by the expansion of rice Source: Field survey, AuthorAntwi-Bediako, 2015. 


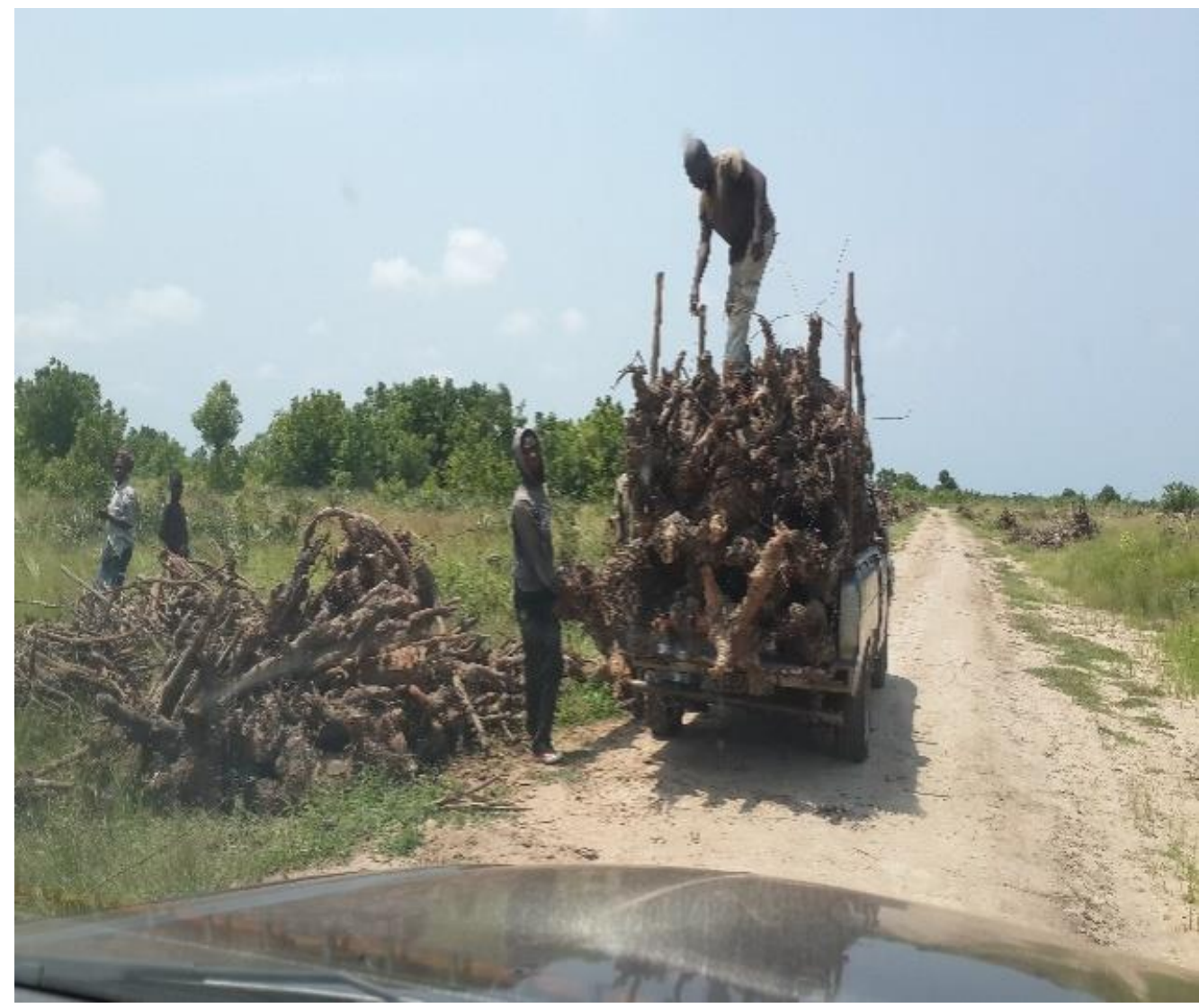

Photo 5.35: Neem trees fetched for firewood and for sale before rice investment Source: Field survey, Author, 2015.

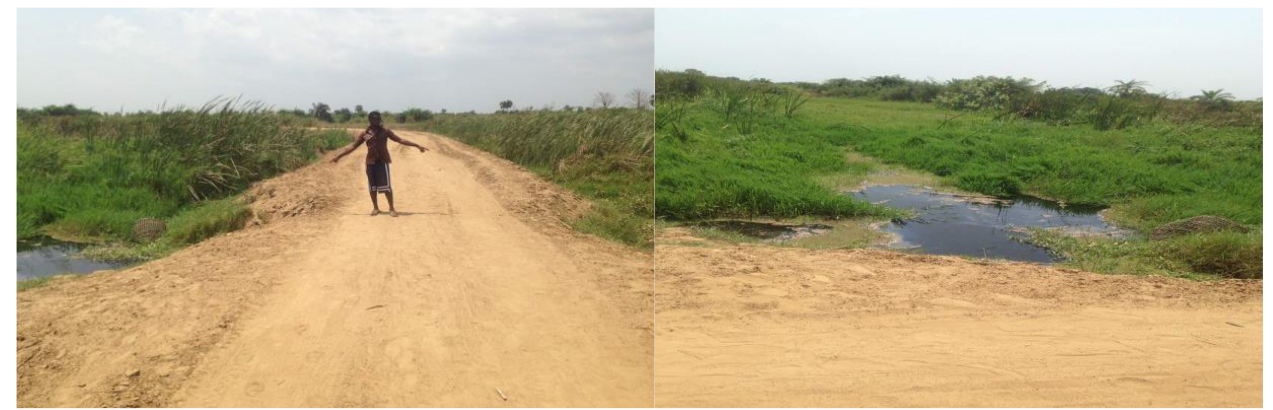

Photo 5.36: River blocked by a road built by the investor to link its factory to its field site Source: Field survey, Author, 2016. 
The lack of a consultation process and the continuous expansion of rice cultivation have led to community agitation especially among common pool users; however, some of those who are employed have better conditions than before. In addition, this situation has led to indifference between the divisional chief of the study area and the Tsiala clan head, the landowner. Since 2016, the divisional chief has prevented the clan head from leasing more lands for the expansion and cultivation of rice.

We heard that the Tsiala clan head and the divisional chief are going through a litigation process at the Agave Traditional Council to define the traditions on land negotiations as to who should lead the negotiations on the next land transaction. (Anonymous, 2017)

Even though the government is not playing any part in this litigation, it does support the expansion of the rice investment to promote its food security agenda in the context of the GCAP.

Transformations of both jatropha and rice cultivation include levels of socioeconomic, socio-political and ecological impacts. Transformation of the 2,300 ha in the era of rice cultivation was severe as compared to the jatropha era, when only 400 of the 2,300 ha were disturbed to make way for planting. As such, there was no threat to most of the species in the area during the jatropha era, as compared to the rice cultivation era, which clearly led to the total enclosure of the land. Socio-economically, the livelihoods of users of common pool resources were reduced, especially for the pastoralists in the era of rice as compared to the jatropha era. However, the rice investment employed 200 community members and, with government support through the GCAP initiative, created opportunities for 30 community members to be part of the out-grower scheme, as compared to the jatropha era when there was no out-grower scheme and only 100 community members were employed. Major conflicts occurred between the landowner and the broker during the transition from jatropha to rice cultivation. The land leases went through dynamics of controversies between the broker and the landowner, thus stalling the process until the rice investor renegotiated with the landowner.

Table 5.5: Summary of impacts of transformations the in jatropha space in Lolito

\begin{tabular}{|c|c|c|c|c|c|}
\hline \multirow[t]{2}{*}{ No } & Impact & \multicolumn{4}{|c|}{ Description } \\
\hline & $\begin{array}{l}\text { classifica } \\
\text { tion }\end{array}$ & Before investment & $\begin{array}{l}\text { During } \\
\text { investment }\end{array}$ & jatropha & $\begin{array}{l}\text { After switch from } \\
\text { jatropha to rice }\end{array}$ \\
\hline
\end{tabular}




\begin{tabular}{|c|c|c|c|c|}
\hline 1 & Tenure & $\begin{array}{l}\text { - Indigenous people and migrants } \\
\text { have access to traditional lands } \\
\text { and systems for farm lands and } \\
\text { grazing. } \\
\text { - No broker interference in land } \\
\text { deals; } \\
\text { - Land deals direct with } \\
\text { landowners. } \\
\text { - Limited or no internal conflict } \\
\text { amongst land-owning clan and } \\
\text { community members on land } \\
\text { issues; } \\
\text { - No competing claims to land } \\
\text { resources. } \\
\text { - Community connectedness } \\
\text { demonstrated stable local norms } \\
\text { to protect local people from } \\
\text { external threats. } \\
\text { - Population mainly indigenous } \\
\text { with a few migrants. } \\
\text { - Few Fulani pastoralists. }\end{array}$ & $\begin{array}{l}\text { - Broker interface in land } \\
\text { deals. } \\
\text { - Access to alternative } \\
\text { common pool resource } \\
\text { like reeds, clay, raffia, } \\
\text { fetching of neem in the } \\
\text { study area. } \\
\text { - Broker annexation of } \\
\text { land for investment; } \\
\text { internal conflict } \\
\text { amongst land-owning } \\
\text { clan; fragility of local } \\
\text { norms to protect local } \\
\text { people from external } \\
\text { threat. } \\
\text { - Partial dispossession, } \\
\text { mainly of indigenous } \\
\text { population and a few } \\
\text { migrants }\end{array}$ & $\begin{array}{l}\text { - Total alienation of } \\
\text { common pool resource } \\
\text { users. } \\
\text { - Broker interface in } \\
\text { land deal. } \\
\text { - Broker subletting land } \\
\text { to new investor, } \\
\text { leading to the } \\
\text { emergence of an } \\
\text { agreement between } \\
\text { investor and } \\
\text { landowning clan. } \\
\text { - Conflict situations } \\
\text { moderated because of } \\
\text { investment (e.g. out- } \\
\text { grower scheme). } \\
\text { - Fully dispossessed, } \\
\text { mainly indigenous } \\
\text { population and a few } \\
\text { migrants and } \\
\text { pastoralists. }\end{array}$ \\
\hline 2 & $\begin{array}{l}\text { Liveli- } \\
\text { hood }\end{array}$ & $\begin{array}{l}\text { - Different livelihood options, e.g. } \\
\text { raffia for mat weaving, } \\
\text { sustainable harvesting of neem } \\
\text { trees for firewood, pottery } \\
\text { making, planting of sugarcane } \\
\text { and distillation of alcohol for } \\
\text { sale; crop farming. } \\
\text { - Use of common pool resource } \\
\text { - Major pastoralism using part of } \\
\text { the common pool resource. }\end{array}$ & $\begin{array}{l}\text { - Out-grower scheme } \\
\text { was part of the } \\
\text { strategies but was not } \\
\text { implemented. } \\
\text { - Farmers (especially } \\
\text { vegetable farmers) } \\
\text { allowed access to } \\
\text { acquired land; cattle } \\
\text { grazing, firewood } \\
\text { business and raffia for } \\
\text { mat-weaving were } \\
\text { impeded; limited } \\
\text { investment in jobs, } \\
\text { migration and internal }\end{array}$ & $\begin{array}{l}\text { - Out-grower scheme } \\
\text { initiated through } \\
\text { GCAP. Integrating } \\
\text { out-grower scheme } \\
\text { business model and } \\
\text { the piloting of } 30 \\
\text { member out-growers } \\
\text { cultivating } 13 \text { ha } \\
\text { under the Ghana } \\
\text { Commercial } \\
\text { Agriculture Project } \\
\text { (GCAP). } \\
\text { Livelihood has } \\
\text { generally worsened, }\end{array}$ \\
\hline
\end{tabular}




\begin{tabular}{|c|c|c|c|}
\hline & & $\begin{array}{l}\text { mobility of some } \\
\text { affected people. } \\
\text { - Employment of } 100 \\
\text { community members. }\end{array}$ & $\begin{array}{l}\text { since local } \\
\text { economic actors } \\
\text { (farmers, herders, } \\
\text { mat weavers, } \\
\text { fishermen, etc.) have } \\
\text { been denied access to } \\
\text { and use of land and } \\
\text { other } \\
\text { resources. } \\
\text { Limited or no access } \\
\text { to common pool } \\
\text { resource like reeds, } \\
\text { clay, raffia and neem } \\
\text { in the study area. } \\
\text { Employment of } 200 \\
\text { community } \\
\text { members. } \\
\text { Indigenous people } \\
\text { can reconnect to } \\
\text { opportunities created } \\
\text { through investment. }\end{array}$ \\
\hline Ecology & $\begin{array}{l}\text { - Presence of common pool } \\
\text { resources sustainably exploited } \\
\text { e.g. reeds, raffia, clay, } \\
\text { floodplains. } \\
\text { - No displacement of indigenous } \\
\text { species because of low } \\
\text { exploitation of the land. } \\
\text { Presence of indigenous species } \\
\text { e.g. sitatunga amphibious } \\
\text { antelope, water fowls, migratory } \\
\text { birds such as egrets, francolins, } \\
\text { kites and wave. } \\
\text { - Sustainable use of creeks and } \\
\text { rivers for irrigating farms and } \\
\text { fishing. Presence of creeks and }\end{array}$ & $\begin{array}{l}\text { - Depletion of } 400 \text { ha of } \\
\text { farmland; destruction } \\
\text { of raffia, grasses and } \\
\text { other resources on the } \\
\text { jatropha land. } \\
\text { - Generally, ecological } \\
\text { resources for local use } \\
\text { were negatively } \\
\text { affected but } \\
\text { community had access } \\
\text { to alternative common } \\
\text { pool resources. }\end{array}$ & $\begin{array}{l}\text { - Conversion of } \\
\text { jatropha to rice and } \\
\text { cultivating } 2,300 \text { ha } \\
\text { and intention to } \\
\text { expand to } 5,000 \text { ha; } \\
\text { pollution of nearby } \\
\text { rivers with } \\
\text { chemicals, } \\
\text { construction of dusty } \\
\text { road causing } \\
\text { pollution. } \\
\text { Generally, ecological } \\
\text { resources are facing } \\
\text { a severe threat } \\
\text { through the gradual }\end{array}$ \\
\hline
\end{tabular}


rivers (e.g. the rivers Ekpe,

Lolidze and Volta); various

varieties of fishes including

tilapia and fresh water clam

locally known as adode.

- Sustainable exploitation of neem

for medicinal and firewood

purposes.

- Presence of short grasses.

Sustainable exploitation by

pastoralists and farmers. expansion of

investment

operations. No

access to common

pool resources.

Source: Author, 2019

\section{Discussion}

The results show that land tenure conflicts and livelihood and ecological impacts (Table 5.5) resulting from large-scale investment initiatives have become more prominent over time. Before the large-scale investments, a large variety of unique traditional systems and common use of the land influenced the interactions among and the connectedness of land users. Common resource structures provide various significant environmental services of social and economic importance to the lives of common pool users. In this regard, there are supporting claims in literature that community members manage their resources in a sustainable manner unlike the corporate use of such resources (Tsikata \& Yaro 2011; Dietz et al. 2003; Agrawal, 2001). In the case of the local community members in the study area, they were responsible for utilizing and managing natural resources, including the land, as their main source of livelihood and sustenance.

In more detail, the solicited community perceptions of the sustainability of common resource use primarily reflect the stories told by the traditional leaders and the indigenous population, which include performance of the traditional systems in land acquisition and land use, access to the varieties of resources in the common pool area which allowed for resources for livelihoods, the undisrupted mobility of pastoralists and familiarity with indigenous agronomic practices. Connectedness and interactions within the communities was exemplified in Lolito and Kpenu where the people were known for farming, mat weaving and the harvesting of neem for firewood, while the Ablekorkope community was known for fishing. Jatropha investment still allowed the common resource use to some extent, but the shift to rice monoculture significantly changed this access mechanism for common resource users. Therefore, 
understanding the socioeconomic conditions in terms of livelihoods - which include land rights, labour conditions, food security and environmental conditions - is important to build interventions towards inclusive sustainable development.

\subsection{Socioeconomic and socio-political transformation of jatropha space}

It is clear from the findings that the elite broker sparked the social, economic and political transformation in the investment space. This is because the broker understood the favourable policy environment for large-scale agricultural commercialization and took advantage of government cooperation to develop the area as an ideal location for agricultural commercialization with favourable biophysical resources. Again, the ineffectiveness of legal processes and institutional pluralism served as a catalyst for large-scale agricultural commercialization (Batterbury \& Ndi, 2018) and played to the advantage of the broker. The broker's 50-year leasehold of common pool resources was a trigger for different dynamics of transformations. Thus, the broker played a conspicuous role in obtaining most of the benefits from large-scale land investments (Fairbarn, 2013).

In the phase when traditional landowners leased land to the elite broker, community consultation was not part of the large-scale land acquisition process. The land was simply handed over to the investor without consulting the land users. It was only when the investor started employing local people that the land acquisition was introduced to the affected communities. In the context of the results, the broker obtained land from the traditional authorities at a minimal price and convinced them of his intense interest in contributing to the transformation of the area. The broker introduced investors to utilize the already grabbed space all in the name of 'rural development', as he told the local leaders and community members and this was widely accepted. This move shows that brokers are interested in rural transformation and advancement.

This supports Anseeuw (2013) and O'Brien (2011), who argue that corporate investors, with the help of brokers, are usually presented to community members and agencies to lure them to believe that large-scale investment will remedy their livelihood deficiencies through employment generation, technology transfer and comprehensive compensation promises. Again, the initiative to establish a foundation to support inclusive investments tends to cement the idea that 'local development' is the main interest of elite brokers.

However, the key question that keeps arising is: are brokers interested in the development of local communities while making huge profits from their tactical land deals? The exit of jatropha and the arrival of a new investment seems to show that brokers are focussed $160 \mid \mathrm{P}$ a g e 
on making huge profits. After the failure of the jatropha investment, the broker was swift to release the jatropha space to another investor without informing the indigenous landowners. Despite brokers' roles in land deals, they have paradoxically received very little blame when issues emerge concerning local community exclusion from land deals. Brokers have commonly acted in their own interest to the detriment of local communities by making undisclosed gains from land negotiations, but they escape the blame (Antwi-Bediako, 2018).

Common pool resource users (e.g. the local farmers, pastoralists and local artisans) did not have the right to participate in land deals as they were seen as having conditional access to the land - a condition that allows landowners to evict land users whenever they deem it fit to lease land out to investors. Therefore, the commoners cannot participate in land deals and face a higher risk of being prevented from using common pool resources without being allowed access to an alternative tenure arrangement.

\subsubsection{Jatropha space and new enclosure}

Agrarian communities have often been said to be 'poor' and to need specific interventions to transform them for development (Fairbairn, 2013; MoFA, 2015). In respect of the emergence of large-scale investment, the reality of investment in both periods of investment (jatropha and rice) was in the national interest - namely to mitigate food insecurity and unemployment - but did not respond well to the needs of local communities. Jatropha and the new monoculture of rice have led to new enclosure and limits on people's access to common pool resources, even though new forms of opportunities have been created through job creation and perhaps outgrower schemes. However, the opportunities do not meet the needs of the local people, who used to be engaged in food crop farming, cattle raising, the sale of firewood, raffia for mat weaving and fishing activities - activities that defined the case community.

Jatropha and the new monoculture of rice gained government support through various policy initiatives. The government, through state institutions, still endorses a neoliberal approach to development (MoFA, 2015), implying that large-scale agro-investments and related transitions that align with ecological, socioeconomic and socio-political realities are likely to be intensified. Both large-scale jatropha and large-scale rice investments have negatively affected community members, but when asked, community members said that they preferred jatropha to rice. This is because during the jatropha era, they had access to alternative land and water resources, but with the cultivation and expansion of rice, more common pool resource users were dispossessed. 
However, the government has taken positive steps within the strategic models and investment of BABGL in terms of improving national food security and reducing overdependence on rice importation. Between 2007 and 2015, rice became a leading import commodity, with imports increasing from USD 151 million in 2007 to USD 1.6 billion in 2015 (GNA, 2018). Therefore, any private initiative complementing the government's efforts to reduce such huge amounts of imported rice is welcomed by the government, because it saves foreign currency. Such a positive step towards food security in Ghana involved the government's strong support for private agri-investments, especially the one initiated by the BABGL under the Ghana Commercial Agriculture Project (GCAP). This shows a general trend of government and some community members applauding the use of land for the production of food rather than non-food, like jatropha. In general it was presumed that biofuel production specifically jatropha - would have competed with food production. However, a shift to largescale food cultivation has its own challenges, which include massive landscape change and limited access to common pool resources for indigenous people and migrants. This is expected to continue due to the endorsement of agricultural commercialization and the government's neoliberal approach to development (Ghana Shared Growth and Development Agenda (GSGDA) 2018-21). For example, the Ministry of Food and Agriculture (MoFA, 2015) has endorsed capitalist-driven agricultural development to substantially advance economic development in a sustainable manner. To that effect, the government has launched three flagship agricultural programmes: 'Planting for Foods and Jobs', 'Rearing for Foods and Jobs' and 'One district, one factory', all of which are driven by corporate investors on large tracts of lands.

The outcomes of large-scale investments have been discordant with local needs and aspirations, adding to the complex question 'Do large-scale food agri-investments complement local economic development in Ghana while mitigating food insecurity?' - a question that underpins arguments for or against corporate investments. In the current development era when global enthusiasm is centred on 'leaving no one behind', which seems to have become a 'tinkling cymbal' in the development space (see United Nations General Assembly, 2015), the need for investment realignment to meet the needs of local people should not be downplayed. If host communities (especially commoners) are to see advancement in their socioeconomic conditions, then inclusive development should be tied to emergent investments. This may, however, remain a tricky puzzle to be solved by development practitioners and thinkers, as large-scale investments tend to distort indigenous growth and development. Altogether, the government's capitalist-driven agenda in Ghana will consistently spearhead corporate $162 \mid \mathrm{P}$ a g e 
investments. So, calling for a swift assessment of investments in an attempt to transform its negative attributions into positive ones can benefit the livelihood conditions of community members rather than completely distort them.

Large-scale investments have, in most cases, been accepted as way to achieve rural transformation and positive livelihood development (Bahrman et al., 2012). Generally, however, rural communities have unique attributes that make them conducive niches for community members. The investment communities, for instance, were very vibrant and provided multiple livelihood options for their members. This intensified local-level cooperation and collaborative development initiatives through strong social ties and relations. Taylor (2010) has argued that there is a need to rethink about local communities and how we perceive them, and that instead of prescribing what needs to be done, local communities' development priorities should be at the forefront. To this end, large-scale agri-investors must align their investment priorities with local initiatives in order to ensure that such investments do not deprive community members of their livelihood opportunities for local economic development.

\subsection{Alteration of ecology and implications for sustainable development}

Local communities usually have vibrant ecological conditions that attract particular types of investment. In Lolito and its environs, for instance, vast areas of land, favourable climatic conditions, abundant vegetation, flood plains, creeks, rivers and forest resources support diverse large-scale crop investments. These conditions also defined local livelihood opportunities such that majority of the community members were, for instance, farmers, herders, mat and pot makers, or fishermen. However, as Zou and Shen (2003) argued, despite the presence of favourable ecological resources and conditions for local livelihood sustainability, development actors have embraced agri-investments that usually lead to the alteration of the local ecological landscape, leading to negative development consequences. Turner et al. (2001), however, indicated that efforts need to be redirected towards protecting local ecological conditions. In fact, investors could develop mechanisms that protect and conserve the local ecology for the benefit of themselves and local communities, with positive multiplier implications for the entire country. Xiao et al. (2004) added that countries are becoming aware of the need to conserve ecological resources and that ecological security has gradually emerged as a major factor influencing national environmental policies, with an increasing number of studies exploring human activities' diverse implications for and influences on ecological services (Sanderson et al., 2002; Venter et al., 2016). This positive 
step is necessary, as this study has further shown the significance of ecological resources for local-level development and sustainability.

Local ecological resources have been altered and this has changed the real potentials of the agrarian communities in the investment spaces. The realities of ecological alterations, for instance, caused through changing investments are in tandem with the diverse and complicated unanticipated socioeconomic and socio-political outcomes. The presence of neem, raffia, water bodies, migratory birds and other special species that defined the ecology and gave it unique attributes has been diminished through the investments in jatropha and now rice.

Corporate investors are to be blamed for the destruction of local ecological resources (Hughes et al. 2011; Cotula et al., 2008), a revelation that supports the realities of changing investments in the case study community. Beroya-Eitner (2006) indicates that as an ecological system is exposed to alterations, for example by large-scale agro-investment, its level of resilience is tested. Ecological systems in rural areas usually have a low level of resilience to alterations (Hong et al., 2006); therefore, investments must be made in a manner that does not downplay the protection of the ecological landscape.

\section{Conclusion}

The findings presented in this chapter suggest that jatropha and the new monoculture of rice led to new enclosure and limits on local people's access to common pool resources, and subsequently ecological landscape alterations. To appreciate the implications of these findings, this chapter described how communities used the land before the investments and how the land offered resources that were vital for local people's livelihoods, including reeds for mat weaving, pasture for grazing and neem trees for firewood. The chapter presented the diverse realities of changing investment implications, including the impacts on the livelihoods of the rural dwellers whose occupations were mostly reliant on common pool resources, and the impacts on local food security because of investors' desire to annex lands initially occupied by local land users and to use them for large-scale agri-investment.

First and foremost, the case has shown that the community felt secure under the traditional systems that had previously protected them and their livelihoods and their stake in the land, and that allowing access to large-scale investment has largely dispossessed those who were using the investment area for their livelihoods. Second, the case has shown that the landowners and the investors often ignored concerns of local community members seeking to find alternative land in and around the investment area. Third, the case has shown that the endorsement of a neoliberal approach to development by the government of Ghana evidences 
its efforts to achieve food security and reduce overdependence on rice importation; however, the neoliberal approach has disadvantaged the rural economy. For instance, the BABGL alliance with the government in the Ghana Commercial Agriculture Project (GCAP) has complemented the government's efforts to mitigate food insecurity in Ghana and partly reduced the importation of huge quantities of rice (over USD 1 billion's worth in 2015), but has also prevented rural farmers from using the land resource for the cultivation of food crops and pastoralism.

The results suggest that any action to change an agrarian rural landscape by promoting monoculture and commercial large-scale investment must consider the entire environment and socioeconomic complexities, because monoculture and commercial agricultural initiatives have several negative implications, which include creating new enclosures and socioecological impacts.

Given the importance of land to both rural and commercial land users, it is imperative to develop clear guidelines to promote inclusive sustainable development and, for example, support the creation of buffer zones for common pool resource users. This can mitigate the loss of livelihood while enhancing food security through agriculture commercialization, which always receives political support from most governments in Ghana. The creation of buffer zones for common pool resource users can ensure ecological sustainability and the livelihoods of people who depend on the environment. This can provide a concrete platform to undertake sound large-scale investment without completely disrupting community conditions and development. Finally, as agri-investments are growing rapidly both in Ghana and in Africa at large, critical studies should focus on the role of brokers in rural land markets and corporate investments. This can help in drawing up insightful policies to govern brokers in such a way that their activities do not have escalating negative implications for rural communities.

\section{References}

Agrawal, A. (2001). Common property institutions and sustainable governance of resources. World Development, 29(10), 1649-1672

.Allan, J.A., M. Kellert, S. Sajama and J. Warner (eds) (2013). Handbook of Land and Water Grabs in Africa: Foreign Direct Investment and Food and Water Security. London: Routledge

Anseeuw, W. (2013). The rush for land in Africa: Resource grabbing or green revolution? South African Journal of International Affairs, 20(1), 159-177. 
Antwi-Bediako, R. (2018). Chiefs and nexus of challenges in land deals: An insight into blame perspectives, exonerating chiefs during and after Jatropha investment in Ghana. Cogent Social Sciences, 4(1), 1456795

Aryeetey, E. and Udry, C. (2010). Creating Property Rights: Land Banks in Ghana,' American Economic Review, 100, 130-34

Bassey, N. (2008). The Agrofuels Debate in Africa: Challenges and Opportunities. In Proceedings of the Ecological Agriculture: Mitigating Climate Change, Providing Food Security and Self-reliance for Rural Livelihoods in Africa Conference, Addis Ababa, Ethiopia, 26-28

Batterbury S.P.J. and Ndi, F. (2018). Land grabbing in Africa. In Binns J.A., K. Lynch and E. Nel (eds) The Routledge Handbook of African Development. London: Routledge. PP 573-582

Beroya-Eitner, M.A. (2016). Ecological vulnerability indicators. Ecological Indicators, 60, 329-334.

Birega, G. (2008). Agrofuels Beyond the Hype: Lessons and Experiences from other countries. In Agrofuel Development in Ethiopia: Rhetoric, Reality and Recommendations; Heckett, T., Aklilu, N. (eds), Forum for Environment: Addis Ababa, Ethiopia, pp.67-83

Cotula, L., Dyer, N., and Vermeulen, S. (2008). Fuelling Exclusion? The Biofuels Boom and Poor People's Access to Land. IIED, London, ISBN: 978-1-84369-702-2

Dietz, T., Ostrom, E., \& Stern, P. (2003). The struggle to govern the commons. Science, 302(5652), 1907-1912. http://dx.doi.org/10.1126/science.1091015

Fairbairn, M. 2013. Indirect dispossession: Domestic power imbalances and foreign access to land in Mozambique. Development and Change, 44 (2), 335-56.

Geertz, C. (1973). Thick description. The interpretation of cultures, 3-30

Ghana News Agency (2018). Ghana Rice importation. https://www.businessghana.com/site/news/business/167665/Ghana-imports-over-US1162-billion-worth-of-rice-annually-Minister

Ghana Statistical Service (2014). 2010 Population and Housing Census. District Analytical Report; South Tongu District. Ghana Statistical Service (GSS), Accra.

Hill J., Nelson E., Tilman D, Polasky S. and Tiffany D. (2006). Environmental, economic and energetic costs and benefits of biodiesel and ethanol biofuels. PNAS, 103, 11206-11210

Hong, W., Jiang, R., Yang, C., Zhang, F., Su, M., Liao, Q., 2016. Establishing an ecological vulnerability assessment indicator system for spatial recognition and management of ecologically vulnerable areas in highly urbanized regions: a case study of Shenzhen. 
$\begin{array}{llll}\text { China. } & \text { Ecological } & \text { Indicators, } & 69,\end{array}$ http://dx.doi.org/10.1016/j.ecolind.2016.05.028.

Hughes, A. K., Knox, A., and Jones-Casey. K., (2011). 'Focus on Land Brief in Africa: Pressure on land from large scale biofuel production'. Lesson 2. World Resources Institute in partnership with Landesa Rural Development Institute. Funded by the Bill and Melinda Gates foundation. IFAD OCCASIONAL PAPER 2.

Manoranjitham, S. \&Jacob, S.K., (2007). Focus group discussion. Journal of the Nursing Association of India, 98(6), 125-127

Ministry of Food and Agriculture (2015). Responsible Agricultural Investment. A report on The Ghana Commercial Agricultural Project (GCAP), Accra-Ghana

O'Brien, E. (2011). 'Irregular and Illegal Land Acquisition by Kenya's Elites: Trends, Processes and Impacts of Kenya's Land Grabbing phenomenon'. ILC Collaborative Research project On Commercial Pressures on Land, Rome.

Openshaw, K.(2000). A review of Jatropha curcas: An oil plant of unfulfilled promise. Biomass Bioenerg.,9, 1-15

Paek, H.J., Reid, L.N., Jeong, H.J., Choi, H. and Krugman, D. (2012). Five decades of promotion techniques in cigarette advertising: A longitudinal content analysis. Health Marketing Quarterly, 29(1), 1-17

Sanderson, K., (2009). Wonder weed plans fail to flourish. Nature 461, 328-329. doi: $10.1038 / 461328 \mathrm{a}$

Sanderson, E.W., Jaiteh, M., Levy, M.A., Redford, K.H., Wannebo, A.V., Woolmer, G., (2002). The human footprint and the last of the wild. Bioscience 52, 891-904.

Sulle, E., and Nelson, F. (2009). Biofuels, Land Access and Rural Livelihoods in Tanzania, IEED: London, UK

Taylor, M. (2000). Communities in the lead: power, organisational capacity and social capital. Urban Studies, 37(5-6), 1019-1035.

Tsikata, D., and Yaro, J. (2011). Land market liberalization and trans-national commercial land deals in Ghana since the 1990s. In: International Conference on Global Land Grabbing, 6,8 .

Turner, M. G., Gardner, R. H., O'neill, R. V., Gardner, R. H., \& O'Neill, R. V. (2001). Landscape ecology in theory and practice (Vol. 401). New York: Springer.

United Nations, General Assembly (2015), Transforming our world: the 2030. Agenda for Sustainable Development, A/RES/70/1 
Venter, O., Sanderson, E.W., Magrach, A., Allan, J.R., Beher, J., Jones, K.R., Possingham, H.P., Laurance, W.F., Wood, P., Fekete, B.M., Levy, M.A., Watson, J.E.M., (2016). Sixteen years of change in the global terrestrial human footprint and implications for biodiversity conservation. Nature Communications, 7.

Xiao, D.N., Xie, F.J. and Wei, J.B. (2004). Regional ecological construction and mission of landscape ecology. Chinese Journal of Applied Ecology, 15 (10) 1731-1736

Zou, C.X., and Shen, W.S. (2003). Advances in ecological security, Rural Eco-Environment, 19 (1) 56-59. 


\section{CHAPTER 6}

Synthesis: Towards inclusive and

sustainable development after

investment failures 


\section{Introduction}

This chapter presents a synthesis of the main findings of the research, which sought to provide key insights for achieving inclusive sustainable development related to large-scale agricultural investments in Ghana. It also discusses the importance of the unpredictability of investment and the ubiquitous possibility of investment failure, and how to protect the most vulnerable people (e.g. migrant farmers) from being negatively affected by the investment and its failure to address the achievement of inclusive sustainable development. As revealed in the empirical chapters, there were trade-offs within the threefold concept of sustainability (i.e. economic development, environmental sustainability and social inclusiveness) that affected the vulnerable population, who are known to be heavily dependent on the ecology of the investment space and the surrounding environment. Furthermore, critical reflections on the threefold concept of sustainability in the empirical chapters showed that paying little attention to political/power issues and conflicts exacerbated the trade-offs within the threefold concepts, thus compromising the achievement of sustainable inclusive development after investment failure.

\section{Research outcomes}

The key objective of this research was to investigate how jatropha spaces were transformed during the operation and following the failure of the investments, and what kind of transformations have contended with local realities. The jatropha investments and subsequent transformations resulted in societal inequalities and complexities within the political and socioeconomic space. Furthermore, jatropha investment and the resulting ecological, sociopolitical and socioeconomic space did not promote inclusive sustainable development because of the progressive exclusion of locals from the investment engagement process. In this regard, the research proposed relevant insights related to large-scale jatropha investments in selected spaces in Ghana.

\subsection{The unintended impacts of jatropha investments}

The research mainly focused on three empirical cases in three jatropha spaces in Ghana to investigate the impacts of large-scale investments and their failure, and to reveal the inherent and unavoidable complexities resulting from large-scale investments and the aftermath of their failure. These complexities are caused by the fact that the investments inevitably changed the relationship between existing tenure arrangements and land conflicts, livelihoods and the 
ecology in the investment space. The findings indicate that land tenure, livelihoods and ecological systems were disrupted by generic processes of unplanned but observable change during investment and after investment failure, affecting the socioecological relationships in a complex way. The complex disruption led to exclusion of some vulnerable community members, especially migrant farmers, from the benefits of the investments.

At the same time, the exclusion led to new mobility dynamics of other migrant farmers to new spaces in search of other livelihood options. This evolved into new transformations that led to new opportunities or insecurities in the socioecological system of the research area. This implies that non-linear development in the context of large-scale agricultural investments in Ghana is inevitable, as complex and dynamic unintended impacts on people's livelihoods and the local economy are expected phenomena.

\subsection{Impact implications observed in the three jatropha spaces}

The three empirical cases revealed the effects of different investment trajectories on tenure arrangements, livelihoods and ecology. The transformation in post-jatropha spaces offered the potential to explore the impact dynamics of the failed investments and the transition to new investment trajectories in the same jatropha investment spaces. In other words, in order to fully grasp the long-term impacts of an investment project, it is important to understand the complexity of tenure issues, subsequent conflicts and livelihoods, and environmental changes. The three cases had different trajectories that emerged in the aftermath of jatropha investments: transformation from jatropha spaces to total abandonment in Kobre; transformation from jatropha to maize cultivation in Agogo; and transformation from jatropha to rice farming in Lolito. This clearly indicates the prevalence of the random transformation of jatropha spaces, which suggests the importance of properly guiding and managing local vulnerability to investments and promoting inclusive sustainable development.

On the other hand, in all the three cases, farmers reported employment during the investment stage as an alternative to their usual livelihoods, as well as the negative effects of the investment in terms of land dispossession, displacement and subsequent depopulation, and local conflicts. The research also indicated that the complexities observed before and during jatropha investment have transformed into new complexities since the investments changed from jatropha to new crops. The transformation from jatropha investment to food crops favoured the national food security agenda and employment for rural land users. However, some rural land users were dispossessed of their lands and livelihoods. That the government strongly promoted corporate-led investment in new crops when there was a boom - without 
making a thorough assessment of local needs, technological viability or commercial feasibility - and endorsed a neoliberal approach to the development and commercialization of agriculture, meant that the government's agenda was large-scale, private-sector driven land expansion rather than local development supporting inclusive sustainable development. Furthermore, the research shows that the outcomes of the aftermath of jatropha investment have been discordant with the expectations placed on the crop and the people. Whilst the environmental resource and social impacts through jatropha investment cannot be ignored, the transformations of investment aftermath are far more intense with complexities that create other unintended and unobservable outcomes that mostly affect marginalized groups in society.

The ecological, economic and social inclusivity changes are underpinned by the changing nature of power relations in the process of large-scale agricultural investments affecting the tenure, livelihoods and ecological landscape of the land users. All three cases show the impacts of large-scale investments on the existing tenure arrangement, livelihoods and ecology. In the Kobre, Agogo and Lolito areas, the relationship between tenure and conflict was created and shaped by the socio-political and institutional environment during the investments and in the aftermath of their failure. Before the investments, land tenure was regulated through a centrally controlled traditional system that gave user rights to migrant farmers with no broker interference. Land tenure arrangement was through shared cropping and the payment of an annual land rent in the form of farm products. This arrangement allowed migrant farmers to live mostly in harmony with indigenous people and without conflicts.

However, the jatropha investment created complexities in the existing tenure system and caused conflicts by changing the dynamics of local tenure against vulnerable migrant groups, and sparking conflicts between two powerful landowners contending for the same plot of land. This resulted in the total land alienation and non-consensual dispossession of migrant farmers in the area, which led to some farmers paying five times more to access alternative land sources. Local citizenship status was also evoked, creating a distinction between migrants and indigenous people and increasing the vulnerability of migrant farmers to landlessness. In the aftermath of the jatropha investments, land abandonment did not guarantee tenure rights for migrant farmers to reuse land because of the continuing litigation between the two contending paramountcies, Kojobofour and Konkomba. This led to the social exclusion of the most vulnerable group - the migrant farmers - and land abandonment.

The situation in the case of the volatile and conflict-prone Agogo environment was characterized by diverse complexities. Triggered by the aftermath of the 1983 bushfires, there was major in-migration, mainly of Fulani herdsmen from the northern part of Ghana and the $172 \mid \mathrm{P}$ a g e 
Sahel region and other parts of Nigeria and Benin. The existing tenure arrangement forced the cohabitation of farmers and Fulani herdsmen, which led to violent conflicts between the two groups and the militarization of the Agogo area. The entry of the jatropha investment and the aftermath of its failure non-consensually dispossessed migrants and indigenous farmers of about 13,000 ha, but both the indigenous farmers and the TC received ground rent for the land they lost. The evocation of local citizenship status created limited opportunities for migrant farmers and pastoralists to acquire alternative lands for farming and grazing, respectively. Increased competition for land between the migrants and the pastoralists has led to continued conflicts outside the investment area, leading to increased militarization. The transformation of jatropha spaces into maize cultivation spaces allowed crop diversification, which contributed to local employment.

In the Lolito area, the jatropha investment and the transition to a new crop alienated commoners from common pool resources. Before the investment, both indigenous and migrant farmers had access to these resources for farming and grazing. The land was initially held by a broker and leased to a jatropha investor. The original community land users were only partially alienated from the use of the commons during the jatropha era since they were given rights to use areas that were not cultivated. Local citizenship status was not visibly evoked, but traditional superiority was prevalent. The traditional landowners non-consensually alienated the commoners and allowed investments to thrive in the area as a preferred option. The transformation to rice cultivation from 2011 totally alienated the community members from accessing about 2,300 ha of common pool resources. However, the introduction of an outgrowers scheme to include the community members in rice cultivation was appreciated as a good step towards inclusive sustainable development.

\section{Towards inclusive sustainable development}

Although the case studies largely highlight the exclusion of marginalized groups from the socioecological system, the present research has identified opportunities to foster inclusive sustainable development. Inclusivity in investments is presented in the literature as the safeguard of and way towards achieving sustainable development. To achieve inclusive sustainable development, the threefold concept of sustainability (economic development, environmental sustainability and social inclusiveness) is promoted globally (UNEP, 2011; World Bank 2012; Gupta \& Vegelin, 2016). For congruence of interests in economic development, environmental/ecological sustainability and social inclusiveness to be achieved, 
there should be no trade-offs between them (UNEP, 2011; World Bank, 2012). While these safeguards of inclusivity are discussed globally as contributing to the achievement of inclusive sustainable development, the empirical chapters of this dissertation reported trade-offs in favour of economic development over the social wellbeing of people and ecological viability in jatropha spaces. These trade-offs also excluded a large number of poor and vulnerable people from benefiting from inclusive sustainable development, which embraces the inclusion of locals in mainstream decision making on investments; the inclusive sustainable growth associated with higher income households, better educational systems, health and nutrition; respect for human rights; and the sustainable use of the ecological space. The challenges of social inclusiveness were rooted in inequality, human rights, entitlement, rural development capacity and resource distribution (Gupta \& Vegelin, 2016; Gupta \& Thomson, 2010). These challenges account for the marginalized sector, places and communities. Ecological issues are interlocked with social issues, in that the resource exploitation by jatropha investments and the aftermath of their failure evolves with three key unpredictable impact dynamics: vulnerability, livelihood and landscape impact dynamics.

Vulnerability impact dynamics showed how poor people, especially migrant farmers, are affected by ecological alterations; livelihood impact dynamics showed the rural poor deprived of the use of ecological resources; and the landscape impact dynamic showed communities' accelerated demand for limited land and water resources by changing the rule of access to these resources. In all these impacts, when the investment fails, the host communities are not able to regain their original ecological state and vibrancy even without any existing commercial investments. In intense situations, such communities could die out, especially if the ecology remains the mainstay for the local people (see Miller, 2011).

The ecological, economic and social interrelations in the study area are largely a reflection of impact dynamics that tend to make inclusive sustainable development unattainable. Policies and laws adopted to facilitate such interactions have not always been enforced to lead to the full realization of inclusive sustainable development. On the other hand, such ramifications as exhibited in cases could limit FDI in future, which could possibly impact the local and the national economy. To reverse this situation, significant policies changes are needed to help safeguard the socioecological system in an inclusive and sustainable way. Lempert (2003) states that a single policy implementation is usually insufficient to tackle a particular development problem and risk, as such diverse policies can be embraced as a means to achieve pro-poor development interventions. 
The case studies show that it is not only the threefold concept that is congruent with inclusive sustainable development. Also the fourth dimension of the powers of local authorities and politicians are important for achieving inclusive sustainable development. This suggests that if government policies and traditional systems are managed, the following interrelated factors and key points can facilitate the achievement of inclusive sustainable development during and after large-scale agricultural investments:

1) To build stronger company-community interfaces, it is important to understand the local context before any investment is made.

2) It is also important to broaden the scope of land acquisition regulations for the better inclusion of local communities in the planning and execution of large-scale investment projects.

3) Governments that promote investments should inform investors about the traditional land dynamics and the land laws, and the traditional cultural and social histories to unlock strategies for achieving inclusive sustainable development.

4) Local complexities that are often not observable by outsiders should be re-examined, and attention should be paid to the micro or local realities.

5) Monitoring and risk management mechanisms should be put in place to prepare for or protect against business failure.

These interrelated factors that foster inclusivity will weaken the entrenched interests of the multiple actors, and then lands offered to investors will strengthen local livelihood conditions and shape ecological situations in a way that helps communities to retain their authenticity and benefit from investments. For example, policies and proactive investment initiatives allowing the significant inclusion of local community members (especially the marginalized) in project planning and implementation could resolve some grievances about land and compensation issues (Ahmed et al., 2019).

\section{Concluding remarks}

Most of the Jatropha investments across the globe have collapsed due to the generally negative development consequences they had on host communities as well as the failure to achieve the 
investment targets of the actors engaged in jatropha cultivation (Ahmed et al., 2019; ArizaKant \& Wu 2011; Montobbio et al., 2010). The findings from the selected countries (Mexico, India, China, Mozambique, Ethiopia and Ghana) indicate that despite the bust of jatropha, the diversities in transformational outcomes (socioeconomic and environmental implications) call for countries to recognize differences in policy interventions vis-à-vis the actors that were engaged in the investment processes. Though it is extremely complicated to suggest general policy actions informed by the outcomes of jatropha investment, a shift from conventional policies to policies that drive investors to investigate unobservable complexities that enhance social inclusion would be a welcome one. There is also the need for inherent inferences, based on the specific outcomes of jatropha failure, to inform country-specific actions towards largescale investments. The policy environment should, however, be seen as system composed of a broad spectrum of interconnected policies where collaborative decisions and actions will work more efficiently to address negative outcomes.

The transformation in the three cases shows that there were inherent and unavoidable complexities that affected the relationships of the local people in the jatropha investment spaces. For example, livelihood benefits in the three jatropha spaces did not make any substantial impact on positive livelihood transformations for the land users, especially migrant farmers, but did support national policies on the mitigation of food insecurity and unemployment for some community members.

Whilst it is necessary and highly recommended that large-scale investments are tailored to meet national strategic interests and the needs of all members of host communities, specific policy safeguards are needed to protect the most vulnerable and to limit social exclusion/dispossession, conflicts and radical landscape change for local communities. Institutional support will thus be needed, especially for migrants, who are mostly the sufferers in land deals. In addition, to safeguard investment and the aftermath of failure and promote local development, policies that tend to only prioritize national and global sustainability interests should be discouraged, the legal incorporation of the government's food security agenda should promote local developmental interests regarding fair benefit arrangements that ensure local resource access and use, and compulsorily advance inclusive sustainable development. The benefit arrangements could include the provision of physical infrastructure, jobs and inclusive business models that are equitable and fair.

The findings show that corporate land acquisitions have been flawed, causing rural land alienation, with negative consequences for local livelihood sustainability. Policy interventions focusing on the development of a comprehensive guideline to guide chiefs' decisions and $176 \mid \mathrm{P}$ a g e 
actions will be necessary to ensure that inclusive participation in land deals leads to local needs and development being addressed. Specifically, in dealing with the impacts of ecological changes and their negative outcomes for host communities, the existing weak state institutions are unequiped to use their legal responsibilities due to resource constraints. Institutional strengthening through comprehensive resource commitment and support will be needed for positive outcomes of investments regarding the environmental resources of host communities. Broad participatory mechanisms involving local actors are also necessary in large-scale land acquisitions to ensure that large-scale investments are aligned with the needs of rural communities. Through such engagements, a contextualized inclusive sustainable development approach could be developed to align with the needs of both investors and local communities.

Again, because of the complexities of the socioecological system, achieving the congruency of interests (that is, the environmental sustainability of the landscape, economic development and viability of the investment, and the social wellbeing of the people) is contentious due to development uncertainties, especially socio-political uncertainties. This dissertation provides a clear view of the hidden socio-political dynamics that take place in the long run in the case of investments.

The politics of a system shapes decision making on land deals. Politics is important, especially in Ghana where the different governmental and traditional authorities sometimes do not interact with each other when it comes to land deals because of diverse political interests. For example, the cases show very clearly that if a broker transacts on behalf of the chieftaincy system, the official environmental and social policies and regulations to protect the interests of the social system are not so visible. Therefore, there is not much point in promoting the usual official discourse about environmental sustainability, social inclusivity and economic development, when we do not know the local politics. That is why this thesis shows the important aspects of local politics during the investments and the aftermath of investment failure.

Investment failure is not the end of the story! It will remain a trigger for lifelong transformations. Thus, further research is needed to evaluate development intervention research. Such would also allow for the investigation of the different dynamics of investment uncertainties and unintended impacts.

Lessons from this research offer an opportunity to observe all the investment trajectories, especially from the collapse of investment to the aftermath of investment, which in turn offers investors and community members an opportunity to critically integrate inclusive 
sustainable development strategies in all development intervention from planning through to the implementation of investments.

\section{References}

Ahmed, A, Campion, BB \& Gasparatos, A. (2019). 'Towards a classification of the drivers of jatropha collapse in Ghana elicited from the perceptions of multiple stakeholders.' Sustainability Science 14.2 (2019): 315-339.

Ariza-Montobbio, P., Lele, S., Kallis, G., \& Martinez-Alier, J. (2010). The political ecology of Jatropha plantations for biodiesel in Tamil Nadu, India. The Journal of Peasant Studies, 37(4), 875-897.

Gupta, J., \& Thompson, M. (2010). Development and development cooperation theory. In J. Gupta \& N. vande Grijp (eds), Mainstreaming climate change in development cooperation: Theory, practice and implications for the European Union (pp. 33-66). Cambridge: Cambridge University Press.

Gupta, J., \& Vegelin, C. (2016). Sustainable development goals and inclusive development. International. Environmental Agreements: Politics, Law and Economics, 16(3), 433 448. https://doi.org/10.1007/s10784-016-9323-z

Kant, P., \& Wu, S. (2011). The extraordinary collapse of Jatropha as a global biofuel. Lempert, R.J. (2003). Shaping the Next One Hundred Years: New Methods for Quantitative, Long-Term Policy Analysis; Rand Corporation: Santa Monica, CA, USA.

UNEP (United Nations Environmental Programme). (2011). Towards a green economy: Pathways to sustainable development and poverty. Nairobi: UNEP.

World Bank. (2012). Inclusive green growth. The pathway to sustainable development. Washington, DC: The World Bank 


\section{Summary}

Jatropha investment was strongly promoted in the late 2000s in response to the growing global demand for climate-friendly fuels, energy security and rural development in the global South. It was hyped in the policy space and trumpeted as development success with such heartening names as 'miracle crop', 'wonder crop', 'biofuel diesel crop', 'poverty-combat crop', 'marginal-land friendly crop' - in other words, the crop that supports inclusive sustainable development. Governments became the major driving force behind jatropha investment, supporting large corporations by formulating policies and enacting laws to stimulate large-scale cultivation through foreign direct investment (FDI). The assumption that jatropha investment can transform the physical, economic and social conditions of local communities through technological influx and higher gains from job creation, and advance economic growth while meeting global energy needs, made jatropha a preferred option for governments in the global South. This assumption is often contrary to local realities, and as such, societal inequalities and complexities within the socio-political and socioeconomic space progressively deprive local people of their basic needs. By the mid-2010s, it was obvious that the interests in and sustainability of jatropha investment was in contention despite government incentives. The prospects for jatropha were poor contrary to the initial hype and the crop was unprofitable to pursue as a business. Large-scale jatropha cultivation was eventually recognized as the first major failure of the investment boom of the 2000s in many countries globally.

By the early 2010s, Ghana, like other countries, had experienced the rapid rise and fall of jatropha investments and the accompanying socioecological transformations. Observations of the failed jatropha investment space have generally juxtaposed the failure within the context of ethical issues resulting from inexplicable complexities, and contentious socio-political and socioeconomic implications. A limited number of scholarly studies have emphasized observations on the aftermath of jatropha investment failure. This raises key questions and made Ghana an interesting case to study to provide new insights. Ghana's case is particularly interesting because of the country's reputation as a major epicentre of jatropha investment spaces with visible investment trajectories of jatropha up to the collapse of the whole scheme.

Taking this knowledge gap as a point of departure, this study provided an in-depth analysis of how the dynamics of investment trajectories transformed jatropha spaces in Ghana, and what the aftermath was of investment failures created in these spaces. Set against this background, this study sought to answer the question: What have been the socio-political and 
ecological consequences of the jatropha boom and bust, and what kind of transformation has taken place since the failure?

To answer the question, Chapter 2 shows how the heightened global interest in jatropha resulted in large-scale investments in jatropha in many developing countries. Many saw jatropha as a green fuel that could possibly be an alternative to fossil fuel, which has adverse implications for climate change. However, jatropha investments failed to meet global expectations, leading to unexpected social, environmental and economic transformations of the investment spaces. This chapter presents a synthesis of the jatropha investment complexities and transformations in six former major jatropha investment destinations in Mexico, India, China, Ethiopia, Mozambique and Ghana based on qualitative conventional content analysis. The findings show that the jatropha boom and bust in different countries contributed to global transformations. In all of the countries studied, promoters - including the central government and private investors - took a 'wait-and-see' approach with positive expectations. The review also found that the intended goal of establishing global jatropha investments to serve as an alternative source of fuel failed because of the unexpected complexities of the hype, which focused on the deferment option (or the 'wait-and-see' approach) for global jatropha investments. Unmet expectations led to a shift of attention from jatropha to other crops (often food crops) or total abandonment. To a larger extent, the findings of the research provide meaningful justification for policy and decision makers in the development space to reflect upon and appraise new investment initiatives or interventions before endorsing them.

Chapter 3 empirically confirms how large-scale jatropha investments and their implications for the agrarian environment and rural livelihoods have received attention in academic discourse by analysing impact trajectories from jatropha investment boom and bust, to the impact dynamics after jatropha failure and the abandonment of jatropha investment, and how the impacts of the failure could be incorporated into the analysis of agrarian change. The findings in the Kobre case show that migrant farmers were evicted from the investment area, and that the investment failure and the abandonment of the land did not result in the restitution of their land access. Rather, due to land conflicts instigated by the investment failure, the migrant farmers suffered from permanent exclusion from the land. The chapter calls for a critical evaluation of the impacts of large-scale land investments and their failure in sociopolitically complex spaces in order to reorient agrarian change towards inclusive sustainable development.

Chapter 4 empirically shows how in the current rural land tenure and agri-investment debate, large-scale agri-investment is often marked by conflicts, exclusion and the alienation of $180 \mid \mathrm{P}$ a g e 
local land users. The findings indicate why the role of the aftermath of large-scale agriinvestment failure and investment diversification does not feature prominently in the current rural land tenure and agri-investment debate. The chapter also shows the historical trajectories of agrarian investment from the pre-investment era to post-investment failure to reveal the knowledge gap surrounding the investment diversification in the jatropha space of the Agogo Traditional Area. The chapter presents significant encounters marked by conflicts between local farmers and pastoralists (Fulani herdsmen) since the 1980s and how jatropha investment in 2007 and investment diversification into maize from 2011 triggered various forms of unpredictable local agrarian transformations in the Agogo Traditional Area. The chapter indicates lessons from investment diversifications to respond to the demands for inclusive sustainable development in large-scale investment spaces where local migrant/indigenous farmers and pastoralists coexist.

The final empirical chapter shows how agri-investments in Ghana and the aftermath of their failure led to a new surge in investment dynamics, whereby lands are increasingly being reoccupied by new types of agricultural monoculture. This chapter explores the trajectory of monoculture investments from jatropha to rice cultivation, and how monoculture investments have enclosed jatropha spaces and exposed the vulnerability of common pool resource users. The outcomes of the study suggest that any action to change an agrarian rural landscape by promoting the new enclosure of large-scale monoculture, must reconsider all environmental and socioeconomic complexities. Given the importance of land to both rural and commercial land users, it is imperative to develop clear guidelines, especially ones that promote inclusive sustainable development.

The concluding chapter presents a synthesis of the main findings of the research, which sought to provide key insights for achieving inclusive sustainable development related to largescale agricultural investments in Ghana. It also discusses the importance of the unpredictability of investment and the ubiquitous possibility of investment failure, and how to protect the most vulnerable people (e.g. migrant farmers) from being negatively affected by the investment and its failure to address the achievement of inclusive sustainable development. As revealed in the empirical chapters, the vulnerable people are also heavily dependent on the ecology of the investment space and the surrounding environment. Hence, inclusive sustainable development must be addressed within the threefold concept of inclusivity ensuring that we safeguard economic, environmental/ecological and social inclusiveness, without trade-offs that compromise the threefold concept of inclusivity. In this research, the trade-off favoured economic growth through jatropha investment, which eventually failed and compromised the 
ecological viability and social wellbeing of a large number of poor and vulnerable people and deprived them of the benefits of inclusive sustainable development. Despite the case study narratives on the exclusion of marginalized groups from the socioecological system, the research identifies opportunities to foster inclusive sustainable development. In the literature, inclusivity in investment is presented as a way to achieve and safeguard sustainable development. To achieve inclusive sustainable development, the threefold concept of inclusivity (economic, environmental/ecological and social inclusiveness) is promoted globally. For congruence of interests in economic, environment/ecological and social inclusiveness to be achieved, there should be no trade-offs between them. While these safeguards of inclusivity are discussed globally as contributing to the achievement of inclusive sustainable development, the empirical chapters of this chapter report trade-offs in favour of economic development over the social wellbeing of the people and ecological viability in jatropha spaces.

This dissertation provides a clear view of the hidden dynamics that will take place in the long run in the case of investments. But investment failure is not the end of the story! It will remain a trigger for lifelong transformations. Thus, further research is needed to evaluate development intervention research, which will offer opportunities for investigating the different dynamics of investment uncertainties and unintended impacts. Lessons from this research offer an opportunity to observe all the investment trajectories, especially from the collapse of investment to the aftermath of investment, which in turn gives investors and community members an opportunity to critically integrate inclusive sustainable development strategies in all development intervention from planning through to the implementation of investments.

\section{Samenvating}

Iets meer dan tien jaar geleden werd investeren in Jatropha sterk gestimuleerd in de hele wereld vanwege de groeiende wereldwijde behoefte aan klimaatvriendelijke brandstoffen, energiezekerheid en plattelandsontwikkeling op het zuidelijk halfrond. Investeren in Jatropha was toen een voorkeursoptie. Het werd omarmt als 'win-win-win' oplossing en gepromoot met hartverwarmende namen als 'mirakelgewas', 'wondergewas', 'biobrandstof-dieselgewas', 'armoedebestrijdingsgewas' en 'marginalegrondvriendelijkgewas'. Het was kort gezegd het gewas dat inclusieve duurzame ontwikkeling ondersteunde. Overheden werden de belangrijkste stuwende kracht achter investeren in Jatropha. Ze steunden de grote bedrijven met beleid en wetten waarmee het op grote schaal verbouwen van Jatropha met directe buitenlandse 
investeringen werd gestimuleerd. De aanname dat investeren in Jatropha kon zorgen voor economische groei en voor transformatie van de lokale fysieke, economische en sociale omstandigheden van lokale gemeenschappen (dankzij technologische influx en het scheppen van nieuwe banen) en dat tegelijkertijd kon worden voldaan aan de wereldwijde energiebehoefte, maakte van Jatropha een voorkeursoptie voor overheden op het zuidelijk halfrond. Deze aanname was vaak in strijd met de plaatselijke realiteit, en maatschappelijke ongelijkheid en complicaties binnen de sociaalpolitieke en sociaaleconomische ruimte zorgden ervoor dat lokale bewoners steeds minder goed konden voorzien in hun basisbehoeften. Ongeveer vijf jaar geleden werd duidelijk dat de belangen bij investeren in Jatropha strijdig waren met de duurzaamheid ervan, alle stimuleringsmaatregelen van overheden ten spijt. In weerwil van de oorspronkelijke hype werd de Jatropha-handel impopulair en onrendabel. Uiteindelijk werd het op grote schaal verbouwen van Jatropha in veel landen uit de hele wereld beschouwd als de eerste grote mislukking van de investeringsgolf van de eerste tien jaar van het nieuwe millennium.

Net als andere landen maakte Ghana iets minder dan tien jaar geleden de snelle groei en instorting mee van Jatropha-investeringen, waarbij sprake was van diverse vormen van sociaalecologische transformaties. Bij de bestudering van de mislukte Jatrophainvesteringsruimte wordt meestal vooral aandacht besteed aan de factoren die aan de mislukking ten grondslag hebben gelegen - de complicaties en controversies die aan de mislukking hebben bijgedragen. Slechts bij een beperkt aantal studies ligt de focus op de nasleep van de mislukte investeringen in Jatropha - de periode nadat de investeringen zijn gestopt. Over de ontwikkelingen in het post-Jatropha tijdperk - en de gevolgen- is slechts weinig bekend. Ghana, tien jaar geleden het epicentrum van Jatopha inveresteringen in WestAfrika vormt een interessante case om inzicht te krijgen in de dynamiek van ontwikkelingen sinds het einde van de 'boom'. Tegen deze achtergrond, en uitgevoerd in regio's die met falende jatropha-projecten werden geconfronteerd, proberen we met dit onderzoek de volgende vraag te beantwoorden: Wat zijn de sociaalpolitieke en ecologische gevolgen geweest van de sterke groei en instorting van Jatropha en wat voor soort transformatie heeft er sinds de mislukking plaatsgevonden?

Om die vraag te beantwoorden starten we in hoofdstuk 2 met een analyse van de opkomst en neergang van Jatropha wereldwijd, toegespitst op- Mexico, India, China, Ethiopië, Mozambique en Ghana. In vrijwel al deze landen werd Jatropha door overheden gepromoot. Velen zagen Jatropha als een groene brandstof die wellicht een alternatief kon vormen voor fossiele brandstof, dat negatieve implicaties heeft in het kader van de klimaatverandering. Het 
hoofdstuk biedt een overzicht van de ontwikkelingen die zich in de verschillende landen hebben voorgedaan, de rol van overheden en particuliere investeerders, en de factoren die hebben bijgedragen aan het falen van Jatropha-investeringen.

In de volgende drie hoofdstukken wordt op basis van veldonderzoek ingegaan op jatropha-investeringen in verschillende regio's binnen Ghana. In hoofdstuk 3 wordt een analyse gemaakt van veranderingen die zich sinds de Japtropha hebben voorgedaan in de regio Kobre. In dit gebied zijn de Japtropha-investeringen aanleiding geweest voor de verdringing van migranten -groepen boeren die voor de Japtropha-plantages het veld moesten ruimen. Ofschoon veel van de Jatropha-plantages inmiddels in onbruik zijn geraakt is de bevolking er niet in geslaagd opnieuw toegang te krijgen tot de grond. Door de tijdelijke investering zijn mensen permanent van hun grond verstoken geraakt. In Hoofdstuk 4 staat de regio Agogo centraal, een gebied waar Jatropha-investeringen hand in hand zijn gegaan met scherpe confrontaties tussen plaatselijke boeren en veefokkers (Fulani-herders). In dit gebied heeft zich een transformatie plaatsgevonden van Jatropha in de richting van grootschalige maisverbouw. Waar ooit Jatropha-velden lagen wordt nu mais verbouwd, maar ook hier zien we grote gevolgen voor de bevolking, zonder dat deze veel invloed hebben kunnen uitoefenen. In dit hoofdstuk wordt aangegeven welke lessen er kunnen worden getrokken uit investeringsdiversificaties zodat kan worden voldaan aan de vraag naar inclusieve duurzame ontwikkeling in grootschalige investeringsruimtes waarin lokale migrerende/inheemse boeren en veefokkers samenleven. Tenslotte wordt in hoofdstuk 5 een analyse gemaakt van de transformatie zoals die zich heeft voorgedaan in de regio Lolito. In dit gebied zijn de voormalige Jatropha-ruimtes vervangen door rijstvelden. De oorsponkelijke bevolking is ingesloten - en is in vele opzichten door de nieuwe investeringen extra kwetsbaar gemaakt. Ook hier zien we dat investeringsplannen onvoldoende zijn voorafgegaan door een analyse van de gevolgen waarbij niet alleen wordt gekeken naar de directe gevolgen voor direct betrokkenen, maar ook de indirecte en translokale effecten.

Het laatste hoofdstuk (6) bevat een samenvatting van de belangrijkste resultaten van het onderzoek. Bij het onderzoek werd in het kader van de grootschalige landbouwinvesteringen in Ghana gezocht naar belangrijke inzichten voor het realiseren van inclusieve duurzame ontwikkeling. Het bevat tevens een bespreking van het belang van de 'onvoorspelbaarheid van investering' en de altijd aanwezige mogelijkheid dat investeringen mislukken. Daarnaast laten we zien op welke manier de kwetsbaarste mensen, zoals migrerende boeren, kunnen worden beschermd tegen de negatieve gevolgen van de investering en de mislukking daarvan, zodat inclusieve duurzame ontwikkeling kan worden bereikt. Zoals we lieten zien in de empirische 184 | P a g e 
hoofdstukken zijn kwetsbare mensen ook in hoge mate afhankelijk van de ecologie van de investeringsruimte en de omgeving daarvan. Inclusieve duurzame ontwikkeling moet dus worden behandeld binnen het drieledige inclusiviteitsconcept om ervoor te zorgen dat we economische, milieutechnische/ecologische en sociale inclusiviteit kunnen waarborgen zonder compromissen te sluiten die afdoen aan het drieledige inclusiviteitsconcept. Bij dit onderzoek ging het om een compromis ten koste van de voordelen van inclusieve duurzame ontwikkeling en ten gunste van economische groei door middel van investering in Jatropha, die uiteindelijk mislukte en de ecologische haalbaarheid en het sociaal welzijn van een groot aantal arme en kwetsbare mensen in gevaar bracht. In weerwil van de casestudy-narratieven over uitsluiting van gemarginaliseerde groepen in het sociaalecologische systeem kan worden opgemerkt dat de lessen uit het onderzoek laten zien op welke manier inclusieve duurzame ontwikkeling kan worden gestimuleerd. In de literatuur werpt inclusieve investering zich op als de manier waarop duurzame ontwikkeling kan worden gewaarborgd. Om deze inclusieve duurzame ontwikkeling te realiseren, wordt wereldwijd het drieledige inclusiviteitsconcept verkondigd (economische, milieutechnische/ecologische en sociale inclusiviteit). Het verenigen van belangen bij economische, milieutechnische/ecologische en sociale inclusiviteit vereist dat er geen compromissen worden gesloten die afdoen aan andere onderdelen. Deze inclusiviteitswaarborgen worden wereldwijd besproken om inclusieve duurzame ontwikkeling te realiseren, maar uit de empirische hoofdstukken blijkt dat er sprake is van compromissen ten gunste van economische ontwikkeling en ten koste van het sociaal welzijn van de mensen en de ecologische haalbaarheid in Jatropha-ruimtes.

Het onderzoek geeft een beeld van de 'verborgen dynamiek' die op de lange duur bij investeringen zal plaatsvinden. Het mislukken van investeringen betekent niet het einde van het verhaal. Het betekent de start van nieuwe ontwikkelingen met een veelheid van bedoelde en onbedoelde ontwikkelingen, niet alleen voor de direct betrokkenen, maar ook andere groepen in aangrenzende regio's. Het blijft een impuls voor levenslange transformaties. Deze studie wijst erop dat verder onderzoek nodig is om ontwikkelingsinterventies te evalueren, en dat biedt manoeuvreerruimte als het gaat om de uitkomsten van investeringsonzekerheden en onbedoelde gevolgen. De lessen van dit onderzoek bieden de mogelijkheid om alle investeringstrajecten te bestuderen, in het bijzonder van de instorting tot de nasleep van de investeringen. Tevens wijzen ze erop dat het met name voor investeerders en leden van de gemeenschap belangrijk is om op kritische wijze strategieën voor inclusieve duurzame ontwikkeling te integreren, van de planning tot de implementatie van investeringen. 


\section{Curriculum Vitae}

Richmond Antwi-Bediako (antwibed@yahoo.com) was born in Accra, Ghana. After growing up mainly in Accra, Richmond pursued a Diploma in Laboratory Technology and then a BSc in Chemistry and Biology, both at the University of Cape Coast, Ghana. After that, he worked for the University of Ghana Medical School, the Radio-pharmacy unit of Ghana Atomic Energy Commission, Teberabie Goldfields and later Transworld Laboratories Limited - a Geochemical Mining Laboratory in Tarkwa, Ghana. As he enjoyed working on environmental issues and development practice, he did a Master's in Environmental Management and Policy at University of Cape Coast in Ghana. For his Master's thesis, Richmond carried out in-depth research titled 'Community-based natural resource management for development - A study in selected sites in Nzema East District of Ghana’.

Richmond then moved to the private sector and was involved in projects in Ghana and other parts of Africa, mainly working on a number of development projects, research and consultancies on land, energy, mining and community development/engagement projects. Examples of his work include leading a team to develop an environmental, socioeconomic and biodiversity baseline and action plan (BAP) for Endeavour Mining, Vimetco Bauxite Limited, BXC Limited, Golden Star Limited, Tropenbos International, Forestry Commission (Ghana), Abosso Goldfields, Golden Star Wassa Mining Company and ELEQTRA-INFRACO. On sustainability and development practice front, he worked on biodiversity and community-based projects for Care International-DANIDA projects, UNDP-GEF, IUCN-NL, International Cocoa Initiative, Ministry of Lands and Natural resources, Ministry for Employment and Social Welfare, Ghana Integrated Aluminium Development Corporation-GIADEC, to reference a few.

From 2010 to 2016, he coordinated a jatropha and rural land use project in Ghana and Ethiopia, under the Conflict and Cooperation Over Natural Resources (CoCooN) project, which was commissioned by Netherlands Organization for Scientific Research (NWO). Within the project, Richmond applied for a PhD position at Utrecht University and in 2015 commenced his $\mathrm{PhD}$ programme. His PhD dissertation titled 'IN THE AFTERMATH OF THE JATROPHA BOOM: Exploring socio-political and ecological dynamics in "failed" jatropha spaces in Ghana' delves into the various transformations causing unknown outcomes and complexities before, during and after the bust of jatropha. Richmond visited jatropha spaces in Ghana where he extensively gathered empirical information during his fieldwork. 


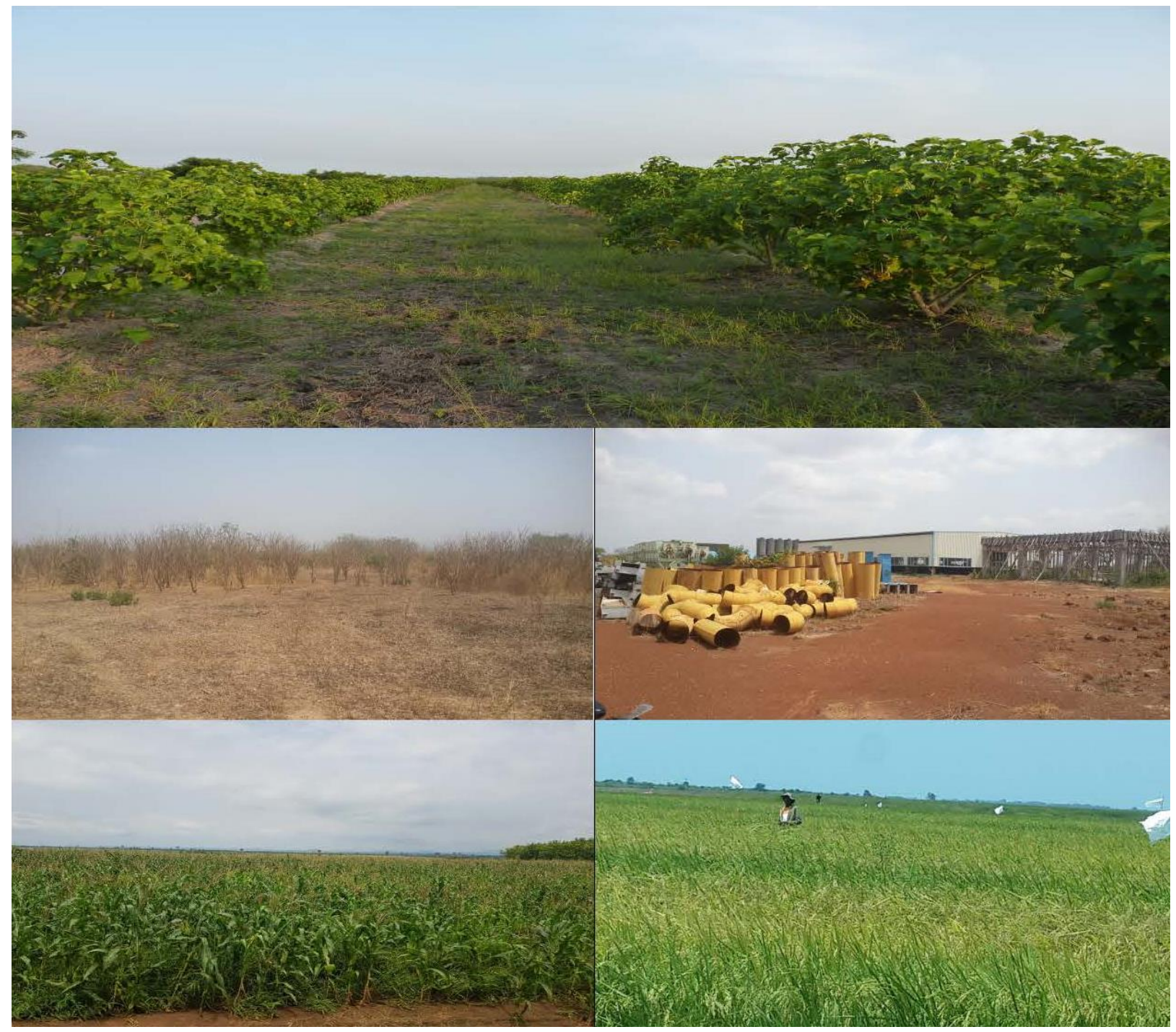

INTHEAFIEMATHOFTFEJATROPHABOOM

Exploring socio-political and ecological dynamics in 'failed jatropha spaces in Ghana 
This Book addresses the knowledge gap in research on large-scale land investment, focusing on investment failure and their aftermath. It provides an in-depth analysis of how investment trajectories transformed jatropha spaces in Ghana, and what happened to these spaces after the investment failed. The book gives an overview of how the heightened global interest in jatropha resulted in large-scale land investments in many developing countries especially: Mexico, India, China, Ethiopia, Mozambique and Ghana. In all of the countries studied, promoters, including government and private investors, took a 'waitand-see' approach, hoping for an economic boom. Consequently, when jatropha investments failed, the promoters were unprepared to deal with unexpected social, economic and environmental impacts of the failure. The Book further zoomed into three case studies of former jatropha spaces created by large-scale investments in Ghana. The results provide a clear view of impacts of investment failures on local ecology, livelihoods and governance, as the investment failures led to total abandonment and/or to investment diversification. Overall, the case studies show that the investment trajectories from jatropha boom to bust have affected vulnerable migrants and common pool resource users. The challenges were rooted in underlying social inequality, resource entitlement, rural development capacity and resource distribution. The Book in conclusion emphasize the importance of building land investment strategies based on solid understanding of local contexts and discusses opportunities to critically evaluate investment failures in order to integrate inclusive sustainable development strategies in land investments. 